


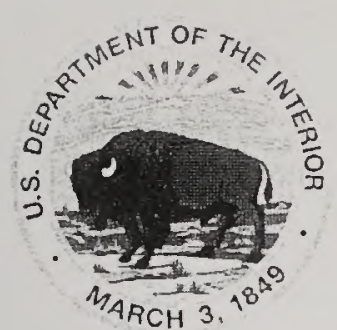

In Reply Refer To: 1610 (IDC020)

\section{United States Department of the Interior BUREAU OF LAND MANAGEMENT \\ Cottonwood Field Office \\ 1 Butte Drive}

Cottonwood, Idaho 83522

\section{SZZ08 Оว 'хәлиә $\angle \rightarrow O S Z \times O Q \circ \cdot 9$ LZG-OO '09.6pIg ләјиәว Іеләрәу ләлиәО

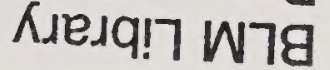

Dear Reader:

Enclosed is the Draft Cottonwood Resource Management Plan (RMP) Amendment for Domestic Sheep Grazing and Supplemental Environmental Impact Statement (SEIS). This draft SEIS supplements the Proposed Cottonwood Resource Management Plan and Final Environmental Impact Statement (Cottonwood PRMP/FEIS) published in 2008. The draft SEIS specifically focuses on domestic sheep grazing on four Bureau of Land Management (BLM) grazing allotments and the associated potential for transmission of disease from domestic sheep to bighorn sheep.

You are invited to review the document and provide written comments, which will be used to prepare the Proposed RMP Amendment/Final SEIS. Please send comments to:

\section{Email to: BLM_ID_SheepSEIS@bIm.gov}

Or postal mail to: $\quad$ BLM Cottonwood Field Office

ATTN: Sheep SEIS

1 Butte Drive

Cottonwood, ID 83522

Comment letters and emails must include your complete name, address, and phone number. Anonymous comments will not be considered. Comments that include specific suggested changes, mention page numbers, or cite sources will be most helpful. Comments on this document must be received within ninety days from the date of the Environmental Protection Agency's publication of the Notice of Availability in the Federal Register.

Before including your address, phone number, e-mail address, or other personal identifying information in your comment, be advised that your entire comment - including your personal identifying information - may be made publicly available at any time. While you can ask us in your comment to withhold from public review your personal identifying information, we cannot guarantee that we will be able to do so.

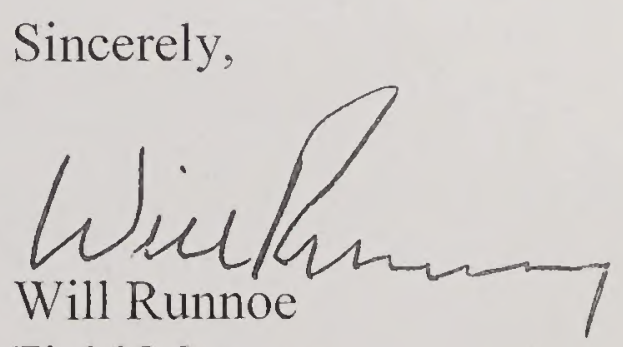

Field Manager 



\title{
DRAFT COTTONWOOD RESOURCE MANAGEMENT PLAN AMENDMENT for DOMESTIC SHEEP GRAZING and SUPPLEMENTAL ENVIRONMENTAL IMPACT STATEMENT
}

United States Department of the Interior Bureau of Land Management

\author{
BLM Cottonwood Field Office \\ 1 Butte Drive \\ Cottonwood, Idaho 83522
}

May 2014 
This page intentionally left blank. 


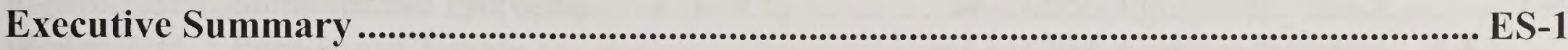

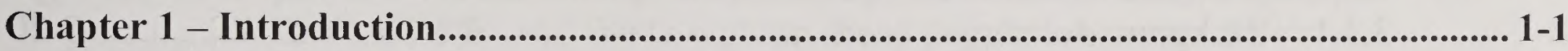

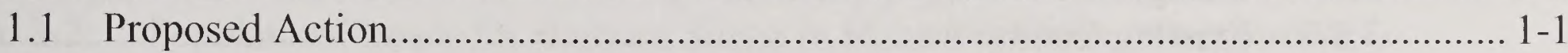

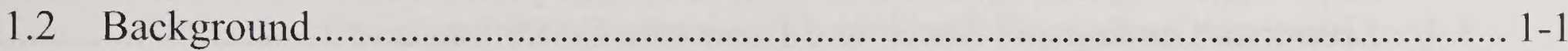

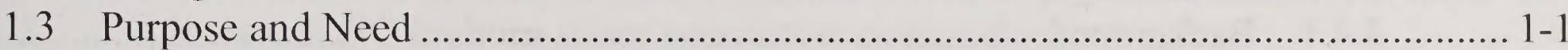

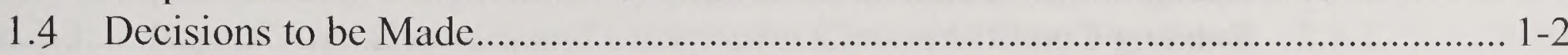

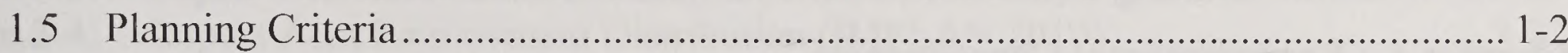

1.6 Description of the Planning Area ……….......................................................... 1-3

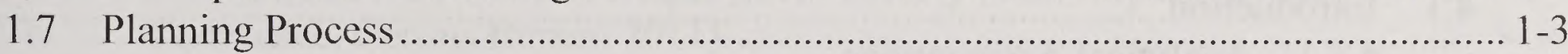

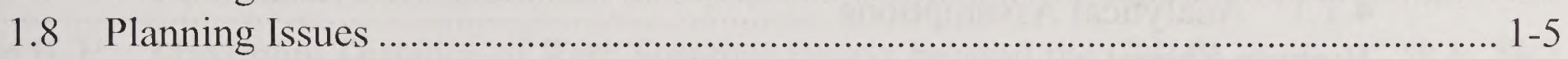

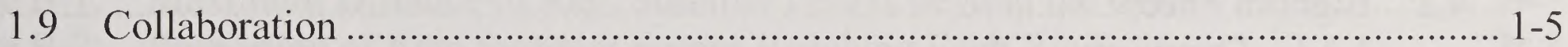

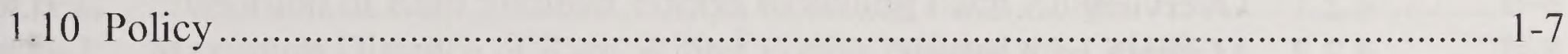

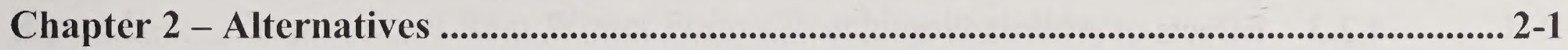

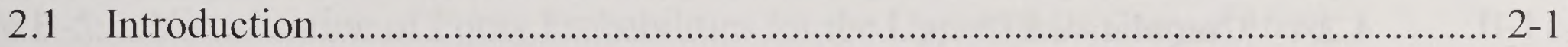

2.2 Decisions from the Approved Cottonwood ROD/RMP with Bearing on the

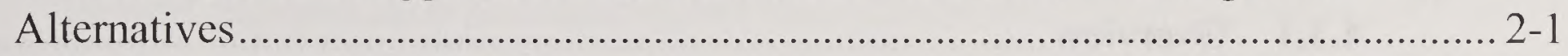

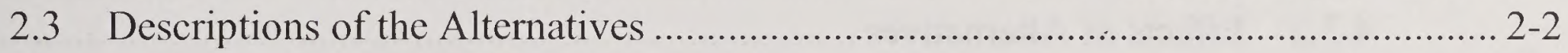

2.3.1 Common to All Alternatives .................................................................. 2-2

2.3.2 Alternative A - No Action Alternative _.................................................. 2-3

2.3.3 Alternative B - Preferred Alternative ……............................................ 2-3

2.3.4 Alternative C - Eliminate Domestic Sheep and Goat Grazing..................... 2-4

2.3.5 Alternative D - Restrict Grazing on Partridge Creek and Hard Creek .......... 2-4

2.3.6 Alternative E - Restrict Grazing on Partridge Creek Only........................... 2-4

2.3.7 Alternative F - Restrict Grazing on Partridge Creek and Marshall

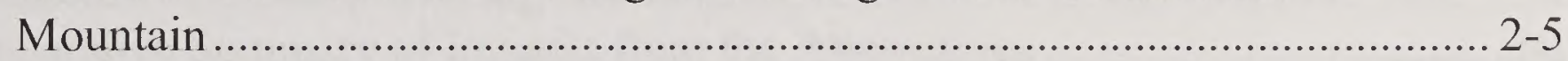

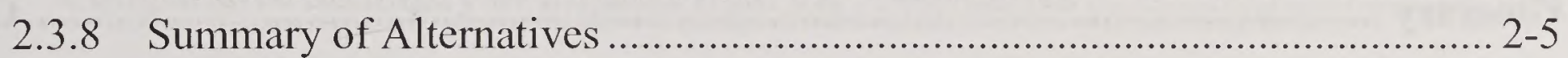

2.4 Alternatives Considered but Eliminated from Detailed Study ……………............. 2-5

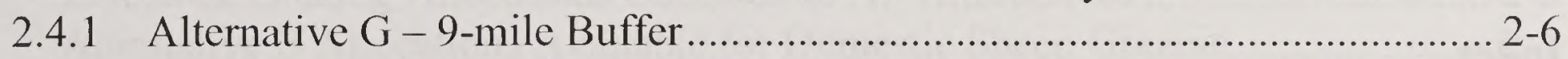

2.4.2 Alternative $\mathrm{H}$ - 1-mile Source Habitat Buffer .......................................... 2-6

2.4.3 Alternative I - 20-mile Buffer ....................................................... 2-6

2.4.4 Alternative J - Geographic Boundaries ................................................... 2-6

2.4.5 Alternative K - Designate Bighorn as a BLM Sensitive Species .................. 2-7

2.4.6 Alternative L - Allow Domestic Sheep and Goat Grazing on All Allotments with Leasing Terms and Conditions to Reduce Potential

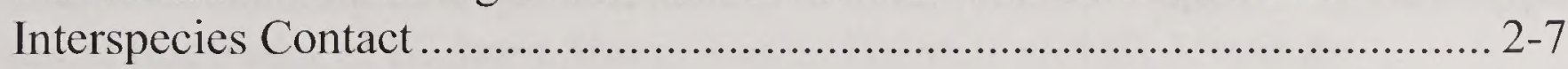

2.5 Summary Comparison of Impacts ...................................................................... 2-7

2.6 Rationale for the Identification of the Preferred Alternative ................................... 2-9

Chapter 3 - Affected Environment ............................................................................... 3-1

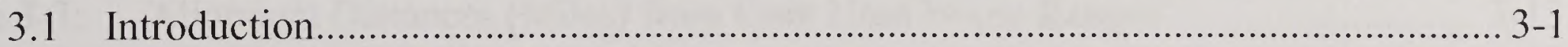

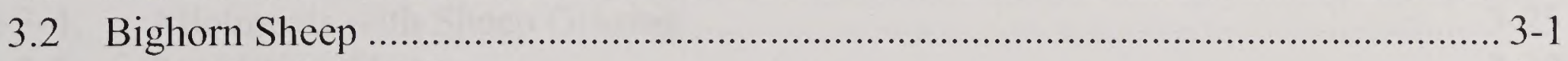

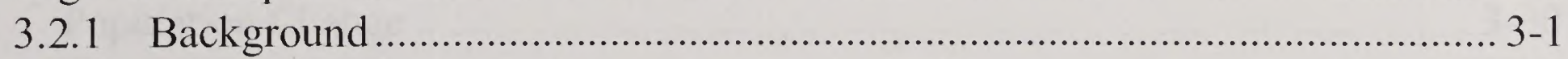




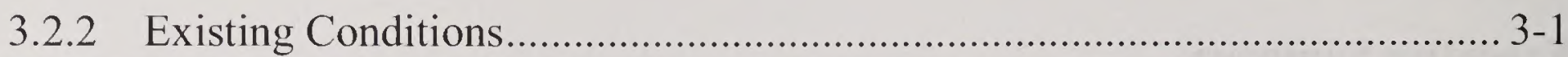

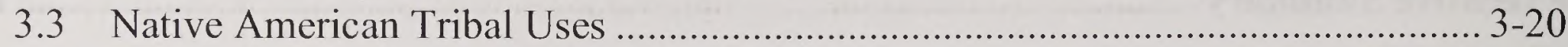

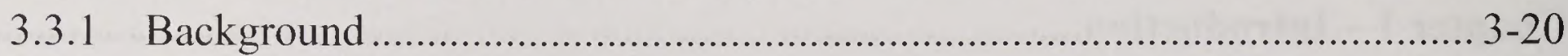

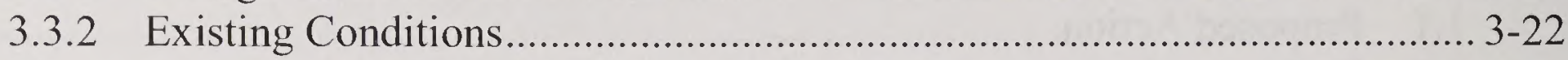

3.4 Livestock Grazing and Social and Economic Conditions ...................................... 3-23

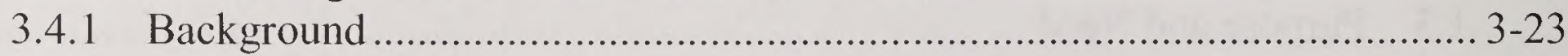

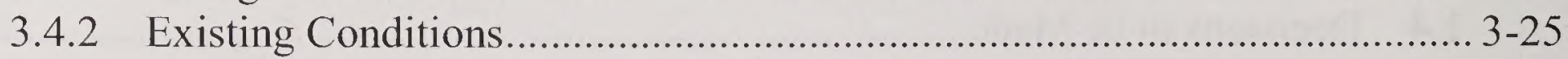

Chapter 4 - Environmental Consequences.......................................................................... 4-1

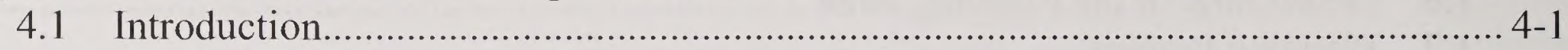

4.1.1 Analytical Assumptions ..................................................................... 4-1

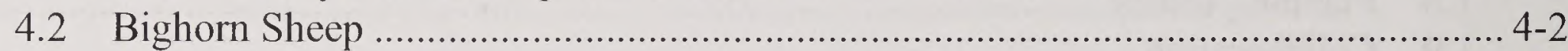

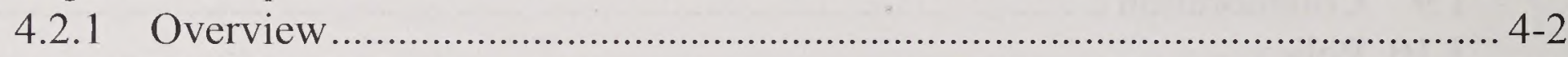

4.2.2 Methods of Analysis .............................................................................. 4-3

4.2.3 Effects of Alternatives ...................................................................... 4-

4.2.4 Cumulative Effects........................................................................ 4-16

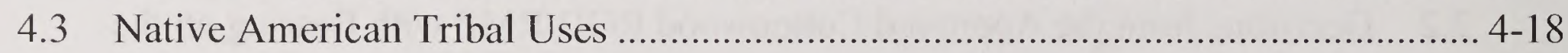

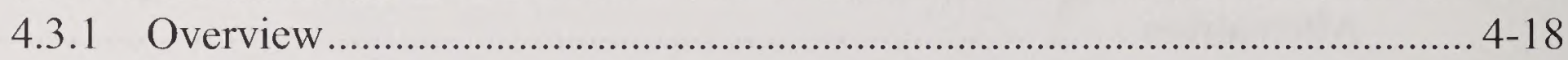

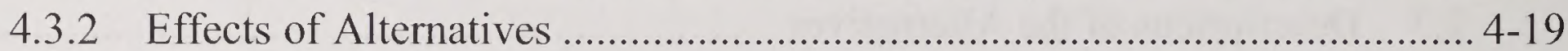

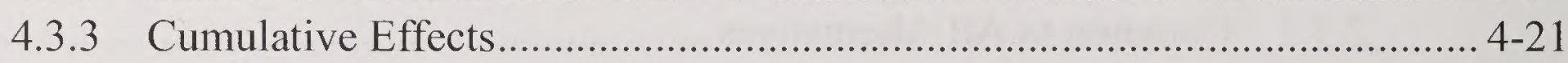

4.4 Livestock Grazing, and Social and Economic Conditions ................................... 4-21

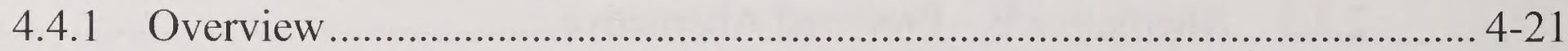

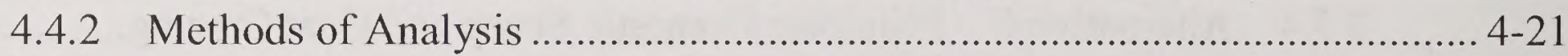

4.4.3 Effects of Alternatives .................................................................... 4-24

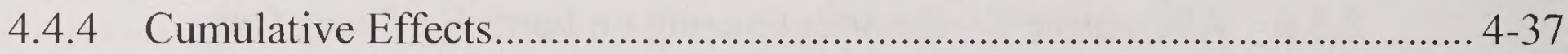

4.5 Irretrievable or Irreversible Commitment of Resources ........................................ 4-39

Glossary Glossary-1

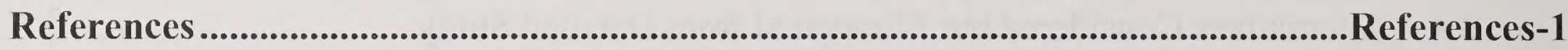

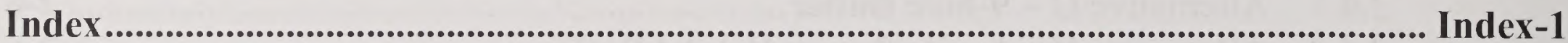

Appendix A - Disease Transmission between Domestic Sheep and Bighorn Sheep............ A-1

Appendix B - Model Analysis Details ..................................................................................1

Appendix C - Domestic Sheep and Goats Grazing Lease Terms and Conditions............... C-1

Appendix D - Maps ............................................................................................................................ D-1 


\section{LIST OF FIGURES}

Figure 1-1: Steps for the Preparation of an RMP $1-4$

Figure 3-1: Population Trends for Bighorn Sheep by Herd in Hells Canyon (Source:

WDFW, ODFW, and IDFG bighorn sheep population census data)

Figure 3-2: Population Trends for Bighorn Sheep in Idaho Big Game Management

Units that Overlap the Main Salmon/South Local Population Analysis Area

(Source: IDFG bighorn sheep population census data) ..................................... 3-9

Figure 3-3: Impact Area Counties and Component Census County Divisions ...................... 3-30

Figure 3-4: Impact Area Employment Distribution (IMPLAN 2010) ................................ 3-32

Figure 3-5: Services and Non-services Employment History (U.S. Department of

Commerce, Census Bureau 2011) .............................................................. 3-34

Figure B-1: Maximum Distance of Ram Summer Forays beyond the CHHR …………............

Figure B-2: Proportion of Ram Summer Forays Reaching Each Ring..................................8

Figure B-3: Maximum Distance of Ram Winter Forays beyond the CHHR ………................B-8

Figure B-4: Proportion of Ram Winter Forays Reaching Each Ring .................................... B-9

Figure B-5: Visualization of Foray Probabilities for the Upper Hells Canyon Herd ............... B-11

\section{LIST OF TABLES}

Table E-1: Allotment Availability for Domestic Sheep and Goat Grazing by Alternative .........3

Table E-2: Acres Available for Domestic Sheep and Goats by Alternative ………….................

Table E-3: Animal Unit Months Available for Domestic Sheep and Goats by

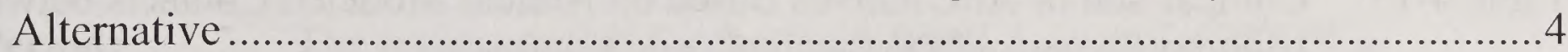

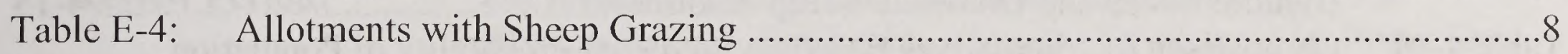

Table E-5: Comparative Summary of Impacts from the Alternatives..........................................10

Table 2-1: Livestock Grazing Allocations Common to All Alternatives ................................ 2-2

Table 2-2: $\quad$ Alternative B Allocations Available for Domestic Sheep Grazing ........................ 2-4

Table 2-3: Alternative D Allocations Available for Domestic Sheep Grazing …................... 2-4

Table 2-4: Alternative E Allocations Available for Domestic Sheep Grazing ........................ 2-4

Table 2-5: Alternative F Allocations Available for Domestic Sheep Grazing ……................ 2-5

Table 2-6: Acres Available for Domestic Sheep by Alternative ……................................. 2-5

Table 2-7: Animal Unit Months Available for Domestic Sheep by Alternative ……............. 2-5

Table 2-8: Comparative Summary of Impacts from the Alternatives..................................... 2-9

Table 3-1: Allotment Summary of Bighorn Sheep Source Habitats and BLM Lands

Leased for Domestic Sheep Grazing ............................................................... 3-11

Table 3-2: $\quad$ Summer and Winter Core Herd Home Ranges and Domestic Sheep

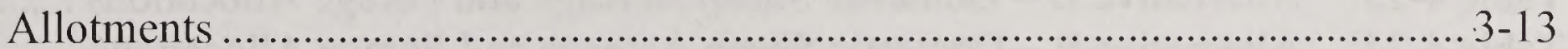

Table 3-3: Allotment Distances (Miles) from Core Herd Home Ranges ${ }^{1}$............................. 3-13

Table 3-4: Allotments with Sheep Grazing ………….................................................. 3-25

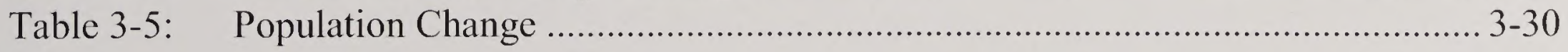




\section{LIST OF TABLES}

Table 3-6: Racial and Hispanic Composition of 2010 Population (in percentages) .............. 3-31

Table 3-7: $\quad$ Sheep and Lamb Inventory and Estimated Annual Forage Requirement ............ 3-38

Table 4-1: Habitats and Core Herd Home Range Available for Domestic Sheep

Grazing under Alternative A ............................................................................. 4-8

Table 4-2: $\quad$ Model Results and Predicted Effects on Individual Herds from

Alternative A

Table 4-3: Habitats and Core Herd Home Range Available for Domestic Sheep

Grazing under Alternative B ...................................................................... 4-9

Table 4-4: $\quad$ Model Results and Predicted Effects on Individual Herds from Alternative B .... 4-9

Table 4-5: Habitats and Core Herd Home Range Available for Domestic Sheep

Grazing under Alternative D...

Table 4-6: Model Results and Predicted Effects on Individual Herds from

Alternative D

Table 4-7: Habitats and Core Herd Home Range Available for Domestic Sheep

Grazing under Alternative E........................................................................ 4-12

Table 4-8: Model Results and Predicted Effects on Individual Herds from Alternative E .. 4-12

Table 4-9: Habitats and Core Herd Home Range Available for Domestic Sheep

Grazing under Alternative F ......................................................................... 4-13

Table 4-10: $\quad$ Model Results and Predicted Effects on Individual Herds from Alternative F... 4-13

Table 4-11: Source Habitat and Core Herd Home Range Available for Domestic Sheep

Grazing by Alternative .............................................................................. 4-14

Table 4-12: Distance between Herd Core Herd Home Range and BLM Lands Available

for Domestic Sheep Grazing by Alternative ……………................................ 4-15

Table 4-13: Comparison of Alternatives Based on Annual Modeled Contacts between

Bighorn Sheep and Domestic Sheep Allotments

Table 4-14: Comparison of Alternatives Based on Predicted Probability of Population

Persistence and Desired Sustaining Trends.

Table 4-15: Modeled Contact Rates between Bighorn Sheep and Domestic Sheep

Allotments and Additional Cumulative Effects from Adjacent Land

Ownerships

Table 4-16: Measures and Analysis Methods .............................................................. 4-22

Table 4-17: Alternative A - Continue Use of Domestic Sheep Allotments ........................... 4-24

Table 4-18: Effects on Local Employment and Income from Sheep Grazing by

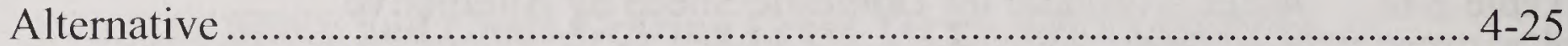

Table 4-19: Expenditures per Visit by Activity and Trip Type …….................................. 4-26

Table 4-20: Employment and Labor Income Response Coefficients by Activity Type ......... 4-27

Table 4-21: Alternative B - Domestic Sheep Acreage and Forage Allocations.................... 4-28

Table 4-22: Alternative C - Domestic Sheep Acreage and Forage Allocations..................... 4-31

Table 4-23: Alternative D - Domestic Sheep Acreage and Forage Allocations ................... 4-32

Table 4-24: Alternative E - Domestic Sheep Acreage and Forage Allocations ...................... 4-34

Table 4-25: Alternative F - Domestic Sheep Acreage and Forage Allocations ....................... 4-35 


\section{DRAFT COTTONWOOD RESOURCE MANAGEMENT PLAN AMENDMENT FOR DOMESTIC SHEEP GRAZING AND SUPPLEMENTAL ENVIRONMENTAL IMPACT STATEMENT}

1. Responsible Agency: United States Department of the Interior Bureau of Land Management

2. Type of Action: Administrative

3. Document Status: Draft

4. Abstract:

The Draft Cottonwood Resource Management Plan (RMP) Amendment for Domestic Sheep Grazing and Supplemental Environmental Impact Statement (SEIS) describes and analyzes six alternatives for the management of domestic sheep on 19,405 acres of public land in Idaho and Adams counties, Idaho, administered by the Bureau of Land Management, Cottonwood Field Office. The SEIS is a supplement to the analysis in the Proposed Cottonwood Resource Management Plan and Final Environmental Impact Statement, published by this office in 2008. The purpose of this RMP Amendment/SEIS is to address concerns regarding the potential transmission of disease from domestic to bighorn sheep. In addition, the SEIS presents the analysis of related impacts to the interests and rights of the Nez Perce Tribe, and to the local social and economic conditions.

5. Review Period: The review period for the Draft RMP Amendment/SEIS is 90 calendar days, and begins when the Environmental Protection Agency publishes a Notice of Availability in the Federal Register.

\section{For Further} Information Contact:

BLM Cottonwood Field Office

1 Butte Drive

Cottonwood, ID 83522

Telephone: (208) 962-3245

Email: BLM_ID_SheepSEIS@blm.gov

Website: http://on.doi.gov/141nQks 
This page intentionally left blank. 
Acronym AMS

AUM

BLM

BMP

CCD

$\mathrm{CdA}$

CEQ

$\mathrm{CFO}$

CFR

CHHR

DSEIS

EIS

EPS-HDT

FEIS

FLPMA

$\mathrm{FO}$

FSEIS

GIS

GMU

GPS

HCBSRC

ID

IDFG

IDIM

IHL

ISDA

LANDFIRE

MFP

NEPA

NVN
Analysis of the Management Situation

Animal Unit Month

Bureau of Land Management

Best Management Practice

Census County Division

Coeur d'Alene

Council on Environmental Quality

Cottonwood Field Office

Code of Federal Regulations

Core Herd Home Range

Draft Supplemental Environmental Impact Statement

Environmental Impact Statement

Economic Profile System Human Dimensions Toolkit

Final Environmental Impact Statement

Federal Land Policy and Management Act

Field Office

Final Supplemental Environmental Impact Statement

Geographic Information System

Game Management Unit

Global Positioning System

Hells Canyon Bighorn Sheep Restoration Committee

Idaho

Idaho Department of Fish and Game

Idaho Instruction Memorandum

Interim Herd Level

Idaho State Department of Agriculture

Landscape Fire and Resource Management Planning Tools

Management Framework Plan

National Environmental Policy Act

Nonviable Herd Number 
Acronym

ODFW

PCPI

PMU

PRMP

RMP

ROD

SEIS

SRBSP

SRMA

SRP

TPI

USDA

USGS

USFS

VHF

WAFWA

WDFW

WOIM

WSA

WWP
Oregon Department of Fish and Wildlife

Per Capita Personal Income

Population Management Unit

Proposed Resource Management Plan

Resource Management Plan

Record of Decision

Supplemental Environmental Impact Statement

Salmon River Bighorn Sheep Project

Special Recreation Management Area

Special Recreation Permit

Total Personal Income

United States Department of Agriculture

United States Geological Survey

United States Department of Agriculture Forest Service

Very High Frequency

Western Association of Fish and Wildlife Agencies

Washington Department of Fish and Wildlife

Washington Office Instruction Memorandum

Wilderness Study Area

Western Watersheds Project 
The Bureau of Land Management (BLM) proposes to amend the Record of Decision and Approved Cottonwood Resource Management Plan (Cottonwood ROD/RMP) (BLM 2009a) by providing new direction for the management and allocation for livestock grazing on 19,405 acres of BLM land within four BLM allotments in Idaho and Adams counties, Idaho (see Map 2 in Appendix D).

\section{Background}

In August 2008, the BLM published the Proposed Cottonwood Resource Management Plan and Final Environmental Impact Statement (Cottonwood PRMP/FEIS) (BLM 2008b); subsequently receiving a number of protests on the proposed decision. The BLM denied all protest points except for one concerning the adequacy of the range of alternatives for the management of domestic sheep and goat grazing on four BLM allotments within bighorn sheep (Orvis canadensis) habitat; specifically as it pertains to the potential disease transmission from domestic sheep and goats to bighorn sheep. As such, this portion of the PRMP/FEIS was remanded to the BLM Idaho State Director, requiring that a supplemental EIS (SEIS) be completed and that the SEIS include a reasonable range of alternatives to address these concerns. The Director further specified that the SEIS would be for the express purpose of analyzing the impacts of domestic sheep and goat grazing within the four allotments.

Currently, no domestic sheep or goat grazing is occurring on any of the four subject allotments. This is the result of a District Court temporary restraining order prohibiting grazing on one allotment, closure of another allotment by the Cottonwood Field Manger, and voluntary non-use by the grazing lessee for the other two allotments.

\section{Purpose and Need}

Disease transmission from domestic sheep to bighorn sheep has potentially contributed to significant declines in bighorn populations and, in some cases, extirpation. The proposed action is needed because domestic sheep and goat grazing on four BLM allotments (Partridge Creek, Marshall Mountain, Hard Creek, and Big Creek) could result in disease transmission to bighorn sheep and contribute to downward trends of local bighorn populations. As identified in protests to the Cottonwood PRMP/FEIS, the BLM must consider this when developing RMP direction for livestock grazing on these four allotments.

The purpose of the proposed action is to provide RMP direction for the management and allocation of livestock grazing on four BLM allotments that includes reasonable means to avoid or mitigate contact with, and potentially consequent disease transmission to bighorn sheep populations. 


\section{Planning Issues}

A Notice of Intent to prepare this SEIS was published in the Federal Register by the BLM on March 12, 2010. Planning issues were identified through the collaboration of governmental agencies and the Nez Perce Tribe. The Payette National Forest and Nez Perce Tribe are formally participating with the preparation of the SEIS as cooperating agencies.

The BLM identified the following planning issues:

- Bighorn Sheep - Domestic sheep and goats may contact and potentially transmit diseases to bighorn sheep; a possible contributing factor to the downward trend in bighorn sheep populations.

- Native American Tribal Interests and Treaty Rights - Management of livestock grazing by the BLM, specifically domestic sheep and goats, may affect the availability of resources and uses (specifically related to bighorn sheep) that are important to the interests and rights of the Nez Perce Tribe.

- Livestock Grazing and Social and Economic Interests - Changes to management of livestock grazing by the BLM may affect the local economy.

\section{Collaboration}

In March 2012, the BLM, Nez Perce Tribe, and Payette National Forest signed a formal cooperating agency agreement for the preparation of this RMP Amendment for Domestic Sheep Grazing and SEIS. The BLM has coordinated with the Nez Perce Tribe, taking into consideration the Tribe's policies regarding the management of bighorn sheep. In addition, the BLM has coordinated with the Payette National Forest and the Idaho Department of Fish and Game (IDFG) regarding the following:

- Record of Decision for the Final SEIS and Forest Plan Amendment Identifying Suitable Rangeland for Domestic Sheep and Goat Grazing to Maintain Habitat for Viable Bighorn Sheep Populations (USFS 2010b)

- Idaho Bighorn Sheep Management Plan (IDFG 2010)

To gain a better ecological understanding of bighorn sheep in the Salmon River Canyon, the BLM participated in the Salmon River Bighorn Sheep Project (an interagency research effort initiated through a Memorandum of Understanding established in 2007) that also included participation by the Nez Perce Tribe, IDFG, Payette National Forest, and Nez Perce National Forest.

The BLM has also participated in the Hells Canyon Initiative; a state, federal, and private partnership established to restore Rocky Mountain bighorn sheep in the Hells Canyon area of Oregon, Idaho, and Washington. Begun in 1995, the Hells Canyon Initiative aims to accelerate restoration of bighorn sheep and to focus research applicable to restoration and management. Other partners include IDFG, Oregon Department of Fish and Wildlife, Washington Department of Fish and Wildlife, and the Wild Sheep Foundation. 
In addition, the BLM collaborated with other stakeholders as a member of the Wild Sheep Working Group of the Western Association of Fish and Wildlife Agencies (WAFWA) in developing Recommendations for Domestic Sheep and Goat Management in Wild Sheep Habitat (WAFWA 2012).

\section{Descriptions of the Alternatives}

The BLM developed five action alternatives to meet the purpose and need. In addition, for analysis purposes, the BLM included a No Action alternative. Because this amendment specifically focuses on addressing the impacts of potential disease transmission from domestic sheep and goats to bighorn sheep, none of the proposed alternatives would close the allotments to other types of livestock grazing (e.g., cattle, horses, etc.). Under all alternatives, all four allotments and specified allocations of forage would be available for grazing by other types of livestock.

The BLM would also develop a separation response plan for bighorn sheep and domestic sheep for any of the four allotments where domestic sheep are allowed to graze. The response plan would define the process, protocols, and timelines for short-term or emergency management actions when intervention is needed to minimize the risk of association between domestic sheep and goats, and bighorn sheep.

The BLM has identified Alternative B as the preferred alternative. In making this identification, the BLM considered its multiple-use and sustained yield mandate, the purpose and need for this RMP Amendment/SEIS, the planning issues, and the results of the effects analysis (Chapter 4). The BLM found that Alternative B provides a means to allow for compatible multiple uses (in this case, domestic sheep grazing and bighorn sheep habitat) with low potential for adverse effects to bighorn sheep populations.

Tables E-1, E-2, and E-3 illustrate the allotment, acreage, and animal unit month (AUM) availability for domestic sheep and goats by alternative.

\begin{tabular}{|l|c|c|c|c|c|c|}
\hline Table E-1: & Allotment Availability for Domestic Sheep and Goat Grazing by Alternative \\
\hline \multicolumn{1}{|c|}{ Allotment } & Alternative A & $\begin{array}{c}\text { Alternative B } \\
\text { (Preferred) }\end{array}$ & Alternative C & Alternative D & Alternative E & Alternative F \\
\hline Partridge Creek & Yes & No & No & No & No & No \\
\hline Marshal Mountain & Yes & No & No & Yes & Yes & No \\
\hline Hard Creek & Yes & No & No & No & Yes & Yes \\
\hline Big Creek & Yes & Yes & No & Yes & Yes & Yes \\
\hline
\end{tabular}

\begin{tabular}{|l|r|r|r|r|r|r|}
\hline Table E-2: & Acres Available for Domestic Sheep and Goats by Alternative \\
\hline \multicolumn{1}{|c|}{ Allotment } & Alternative A & $\begin{array}{c}\text { Alternative B } \\
\text { (Preferred) }\end{array}$ & Alternative C & Alternative D & Alternative E & Alternative F \\
\hline Partridge Creek & 9,544 & 0 & 0 & 0 & 0 & 0 \\
\hline Marshal Mountain & 4,212 & 0 & 0 & 4,212 & 4,212 & 0 \\
\hline Hard Creek & 5,210 & 0 & 0 & 0 & 5,210 & 5,210 \\
\hline Big Creek & 439 & 439 & 0 & 439 & 439 & 439 \\
\hline Total & $\mathbf{1 9 , 4 0 5}$ & $\mathbf{4 3 9}$ & $\mathbf{0}$ & $\mathbf{4 , 6 5 1}$ & $\mathbf{9 , 8 6 1}$ & $\mathbf{5 , 6 4 9}$ \\
\hline
\end{tabular}




\begin{tabular}{|l|r|r|r|r|r|r|}
\hline Table E-3: Animal Unit Months Available for Domestic Sheep and Goats by Alternative \\
\hline \multicolumn{1}{|c|}{ Allotment } & Alternative A & $\begin{array}{c}\text { Alternative B } \\
\text { (Preferred) }\end{array}$ & Alternative C & Alternative D & Alternative E & Alternative F \\
\hline Partridge Creek & 431 & 0 & 0 & 0 & 0 & 0 \\
\hline Marshal Mountain & 166 & 0 & 0 & 166 & 166 & 0 \\
\hline Hard Creek & 218 & 0 & 0 & 0 & 218 & 218 \\
\hline Big Creek & 81 & 81 & 0 & 81 & 81 & 81 \\
\hline Total & $\mathbf{8 9 6}$ & $\mathbf{8 1}$ & $\mathbf{0}$ & $\mathbf{2 4 7}$ & $\mathbf{4 6 5}$ & $\mathbf{2 9 9}$ \\
\hline
\end{tabular}

\section{Affected Environment}

\section{Bighorn Sheep}

The analysis area for bighorn sheep in this SEIS includes the Hells Canyon and Salmon River metapopulations. The analysis focuses on six herds and one area of concern (Little Salmon) that occur in proximity to the four domestic sheep allotments within these metapopulations.

As illustrated on Map 1 in Appendix D, occupied bighorn sheep habitat in Idaho, Oregon, and Washington occurs in the Salmon River and Snake River drainages of the Columbia River Basin (WAFWA 2010). Idaho bighorn sheep exist in both small isolated populations (herds) and interconnected metapopulations (IDFG 2010). Two Rocky Mountain bighorn sheep metapopulations occur within the analysis area, one within the Hells Canyon section of the Snake River and the other within the Salmon River canyon and mountains. Historically, these populations were likely connected by suitable habitat between the two major drainages and may have functioned as one metapopulation.

More than 10,000 bighorn sheep may have once lived in the Hells Canyon and surrounding mountains, but were extirpated by the mid-1940s by competition for forage with domestic livestock, disease, and unregulated hunting (Hells Canyon Bighorn Sheep Restoration Committee [HCBSRC] 2005). Reintroduction efforts in Hells Canyon began in 1971, with 474 bighorn sheep transplanted between 1971 and 2004 (HCBSRC 2005). In 2005, the HCBSRC estimated that 875 bighorn sheep were located within Hells Canyon, and the 2011 population estimate is 850 (includes Idaho, Oregon, and Washington). Overall, Hells Canyon modeled habitat could support more bighorn sheep than current population levels. The Hells Canyon PMU (Idaho) predicted bighorn sheep supportable by habitat within the distribution area of bighorn sheep is 1,555 to 2,802 (IDFG 2010). Cassirer and Sinclair (2007) describe the effects of chronic, repeated pneumonia outbreaks on bighorn sheep populations in Hells Canyon, and their potential adverse effects on bighorn sheep population recovery and persistence.

The Salmon River metapopulation was never extirpated (Toweill and Geist 1999), although the population has experienced periodic die-offs. No reintroduction or augmentation has occurred in the Lower Salmon River Population Management Unit (PMU) (IDFG 2011). Low recruitment rates and an overall decline in sheep numbers over the years for this metapopulation may have been caused by disease and habitat conditions in this PMU (IDFG 2010). Population numbers have dwindled in the western portion of this PMU that is closest to active domestic sheep allotments, and disease has resulted in low lamb survival in adjacent herds along the Salmon 
River (IDFG 2010). Overall, Lower Salmon River PMU modeled habitat could support more bighorn sheep than current population levels. Salmon River PMU predicted populations supportable by habitat within the distribution area of bighorn sheep is 942 to 1,504 (IDFG 2010). Within the Lower Salmon River PMU, Game Management Unit (GMU) 14 is the most western GMU and occurs the closest to domestic sheep grazing and has low lamb survival. During the period of 2010 to 2012 the lamb to ewe ratio was 9.7 (lambs per 100 ewes) within GMU 14. During the same period, the GMUs within the Lower Salmon River PMU that were further east and more distant from historic domestic sheep grazing areas ranged from 57 percent to over 200 percent higher for lamb to ewe ratios when compared to GMU 14 ratios.

Disease, primarily bacterial pneumonia, has played an important role in the dynamics of bighorn sheep populations and has been responsible for numerous population declines throughout North America (Cassirer and Sinclair 2007). A long history of large-scale, rapid, all-age die-offs in bighorn sheep has been documented across Canada and the United States, many presumed to be associated with domestic animal contact (Shackleton 1999). Although there is limited knowledge of transmission dynamics (Garde et al. 2005), extensive scientific research supports a relationship between disease in bighorn sheep populations and contact with domestic sheep.

Three models were developed to better understand bighorn sheep habitat suitability and the potential for contact with domestic sheep. The models developed include (1) a bighorn sheep source habitat model; (2) a core herd home range model; and (3) a risk-of-contact model that utilizes a bighorn sheep source habitat and core herd home range (CHHR) analysis for the bighorn sheep foray analysis. Outputs from these models were used to describe current conditions on BLM domestic sheep allotments and the adjacent areas, and as a basis for alternative comparison. The BLM also used the results from these models to make inferences regarding disease transmission between the species and potential outbreaks of disease within bighorn populations.

In response to bighorn sheep population viability concerns, the Payette National Forest developed a methodology for calculating the probability and rate of contact between bighorn sheep and active domestic sheep allotments (USFS 2010a). Subsequently in 2011, a team of Forest Service and BLM specialists initiated a process to develop a geospatial platform based on the concepts used in the Payette analyses for application on other National Forests or BLM Districts (USFS 2010a; USFS 2013a). The BLM domestic sheep allotments addressed in this SEIS are within the cumulative effects analysis area addressed in the Payette analysis (USFS 2010a); consequently, the analysis, methodology, and resulting Risk of Contact Tool was the chosen modeling method used by the BLM for this SEIS. The models used for this SEIS along with background information and the user's guide are included in the Bighorn Sheep Risk of Contact Tool Users Guide (USFS 2013a). Methods provided by the referenced Risk of Contact Tool provide land managers a framework for addressing and calculating the probability and rates of contact between bighorn sheep and domestic sheep allotments and potential for disease transmission; and subsequent development of bighorn sheep conservation measures (USFS 2013a). The models used in the Risk of Contact Tool have been peer reviewed and have been accepted for publication (O'Brien et al. In Press; Carpenter et al. 2014). 


\section{Bighorn Sheep Source Habitat Model}

Source habitats are those characteristics of macrovegetation that contribute to positive population growth for a species in a specified area and time (Wisdom et al. 2000; Raphael et al. 2001). Source habitats contribute to source environments, which represent the composite of all environmental conditions that result in stationary or positive population growth in a specified area and within a specified time. Within the BLM's Partridge Creek, Marshal Mountain, Hard Creek, and Big Creek domestic sheep allotments, there exists 7,015 acres of summer source habitat and 4,502 acres of winter source habitat.

\section{Core Herd Home Range Model}

The CHHR, an area where the herd spends nearly all of its time, is mapped as a polygon containing 95 percent of all telemetry points from radio-collared (telemetry) or observed bighorn sheep. The four subject BLM allotments contain a total of 8,005 acres of summer and 8,008 acres of winter CHHR.

\section{$\underline{\text { Risk-of-Contact Model }}$}

The risk-of-contact modeling estimates the probability of foraying bighorn sheep reaching a domestic sheep allotment. By definition, contact occurs where the CHHR overlaps an allotment; it is assumed that at least one potential contact per year may occur (USFS 2013). The characteristics of bighorn sheep movements, or forays, outside of the CHHR are examined; including how frequently and at what season foray movements occur, and how far beyond the CHHR animals are likely to travel.

Together, the habitat, CHHR, and risk-of-contact models were used to estimate the probability that a ewe or ram in any of the herds would reach any of the domestic sheep allotments in a given year. Thus, the risk of contact is related to the distance between the CHHR and the allotments available for domestic sheep or goat grazing.

\section{Uncertainties Regarding Interspecies Contact and Disease Outbreak and Analysis Assumptions}

A high degree of uncertainty exists regarding the probability that contact of a bighorn sheep with an allotment will lead to disease outbreak occurring within a herd (USFS 2010a, USFS 2013b; Carpenter et al. 2014; O'Brien et al. In press). Quantifying disease transmission and outbreaks in bighorn sheep populations following contact with domestic sheep or goats, and the subsequent ability of a population to recover are essential to interpreting the results from the above models. However, the mechanism of disease transmission and the resulting outbreaks in bighorn sheep is not fully understood, as we lack the empirical data to make recommendations on the frequency of outbreaks and on the effects on population persistence (Carpenter et al. 2014; O'Brien et al. In press).

Probabilities of a disease outbreak given contact are considered low ( 0.05 or 1 in 20 contacts leads to a disease outbreak), moderate ( 0.25 or 1 in 4 contacts lead to a disease outbreak), or high (1.0 or every contact results in a disease outbreak); intermediate values identified above were also assessed. For this analysis the "moderate" assumption was used ( 1 in 4 contacts leads to disease outbreak). This was the same assumption used for the adjacent Payette National Forest 
analysis (USFS 2010a, USFS 2010b), the Payette analysis also a assessed a similar range of assumptions regarding contact and disease outbreak would occur. Therefore, the BLM relied on the following assumptions to assist with data interpretation:

- The probability that contacts with domestic sheep or goats will result in disease outbreak in a bighorn population is 1 in 4 (or 25 percent - 0.25).

- If a bighorn population suffers a disease outbreak more frequently than once every 50 years, the population may not fully recover, which may lead to extirpation.

The above assumptions indicate that a herd may not fully recover and will have moderate or high risks of extirpation if the probability of contact is equal to, or exceeds, 0.08 contact per year; or one contact every 12.5 years. Assuming that contact between bighorn sheep and domestic sheep or goats results in a 25 percent chance of disease outbreak, at this rate of contact an outbreak will occur every 50 years. Hence, this would be an appropriate level of risk for long-term management of domestic sheep and goat grazing while providing adequate habitat for bighorn sheep populations. The same level of risk was also used for the rationale in the Payette analyses (USFS 2010a; 2010b). The analysis conducted for the Payette analyses and this SEIS incorporated a large amount of scientific literature, input from many bighorn sheep experts and modeling that incorporates current best science modeling (USFS 2010a; USFS 2010b; Carpenter et al. 2014; O'Brien et al. In press). In addition to using best science available for the analysis, such assessment also revealed the existing uncertainties in that science.

Although we still lack empirical data to make recommendations on the periodicity of outbreaks and the effects on bighorn sheep, the above assumptions provide a good benchmark to ensure population persistence until better data is available (USFS 2013b); the Payette analyses used a similar benchmark (USFS 2010a, 2010b). Recognizing the uncertainty regarding contact and disease outbreak, this threshold provides for low to very low risk to bighorn sheep populations not recovering from potential disease outbreak and provides for population persistence. Based on the consequences of disease outbreak, bighorn sheep population recovery, and long-term herd persistence; this appears to be the appropriate risk level (low) for long-term management of domestic sheep and goat grazing while providing adequate habitat for bighorn sheep populations.

\section{Native American Tribal Uses}

Traditionally, socio-cultural values of the Nez Perce reflect a close relationship with natural resources, including big game animals. At times, spiritual values are attributed to animals. For instance, the taking of bighorn sheep is more than a subsistence activity. The Nez Perce believe that in sharing a successful hunt, family ties are strengthened and their connection to the local ecology is maintained, forming a link to the past that contributes to maintaining cultural continuity. As such, the act of hunting is reserved under Article 3 of the 1855 Treaty between the United States and the Nez Perce Tribe. Because hunting is a reserved right and is incorporated into the Tribe's socio-cultural system, any change in these Treaty-reserved opportunities has the potential to affect the socio-cultural system of the Nez Perce Tribe. 


\section{Livestock Grazing and Social and Economic Conditions}

Wildlife and outdoor enthusiasts, hunters, photographers, and the general public value the opportunity to view and hunt bighorn sheep. Consumptive and non-consumptive wildlife activities are an important contributor to the economy in Idaho (IDFG 2010). In 2006 estimates for annual hunting and wildlife viewing in Idaho were 187,000 and 754,000 participants, respectively, which resulted in gross expenditures of \$259.7 million and \$265.4 million, respectively (USFWS 2007).

The price and sales of resident and non-resident bighorn sheep tags, including special auction and lottery tags, can be attributed directly to bighorn sheep hunting opportunities. Tag sales for the 2009 season included 85 controlled-hunt permits/tags, 1 auction tag, and 1 lottery tag. Eight non-resident and 77 resident tags were allocated that year. Resident tags sold for $\$ 166.75$ and non-resident tags for $\$ 2,101.75$. The auction tag sold for $\$ 120,000$ in 2009 , and has averaged $\$ 82,450$ per year over the past 10 years (IDFG 2010).

Sheep grazing within the Cottonwood Field Office also plays an important social role, as area residents identify with the tradition, land use, and history of livestock operations. Of note is the intimate culture that surrounds the sheep industry, which is attributable to values such as hard work, tradition, and a love for the animals and the land. These values are emphasized and cultivated in area events such as county fairs, where 4- $\mathrm{H}$ and Future Farmers of America programs contribute to youth education and a sense of community identity. In History of the State of Idaho, Cornelius Brosnan states that, "Idaho has become one of the greatest woolproducing States, but has long been noted for its mutton" (Brosnan 1918).

Table E-4 outlines the current authorizations and status of the four subject grazing allotments.

\begin{tabular}{|l|l|l|l|l|}
\hline Table E-4: & \multicolumn{1}{|c|}{ Allotments with Sheep Grazing } \\
\hline Allotment Name & \multicolumn{1}{|c|}{ Partridge Creek } & \multicolumn{1}{|c|}{ Marshall Mountain } & \multicolumn{1}{c|}{ Hard Creek } & \multicolumn{1}{c|}{ Big Creek } \\
\hline BLM Acres & \multicolumn{1}{|c|}{4,212} & \multicolumn{1}{c|}{5,210} & \multicolumn{1}{c|}{439} \\
\hline Lessee Name & Carlson Livestock Company & $\begin{array}{l}\text { Carlson Livestoek } \\
\text { Company }\end{array}$ & $\begin{array}{l}\text { Soulen Livestock } \\
\text { Company }\end{array}$ & $\begin{array}{l}\text { Soulen Livestock } \\
\text { Company }\end{array}$ \\
\hline $\begin{array}{l}\text { Lease Expiration } \\
\text { Date }\end{array}$ & $2 / 28 / 2014$ & $2 / 28 / 2016$ & $2 / 28 / 2019$ & $2 / 28 / 2019$ \\
\hline Season of Use & $\begin{array}{l}4 / 11 \text { to } 7 / 15 \\
10 / 15 \text { to } 11 / 30\end{array}$ & $07 / 5$ to $08 / 04$ & $6 / 15$ to $7 / 15$ & $6 / 1$ to $10 / 30$ \\
\hline No. of Sheep & 833 & 815 & 1,050 & 8,000 \\
\hline $\begin{array}{l}\text { Permitted Sheep } \\
\text { Use in AUMs }\end{array}$ & 431 & 166 & 218 & 81 \\
\hline Current Status & $\begin{array}{l}\text { District Court Temporary } \\
\text { Restraining Order } \\
10 / 14 / 2009\end{array}$ & $\begin{array}{l}\text { Temporary Closure by } \\
\text { BLM Decision } \\
3 / 15 / 2011\end{array}$ & $\begin{array}{l}\text { Lessee has } \\
\text { voluntarily taken } \\
\text { non-use }\end{array}$ & $\begin{array}{l}\text { Lessee has } \\
\text { voluntary taken } \\
\text { non-use }\end{array}$ \\
\hline
\end{tabular}

\section{Environmental Consequences}

Table E-5 summarizes the estimated environmental consequences (impacts) from implementation of each of the alternatives. Following is a brief explanation of each key indicator as presented in the table. 
- Bighorn Sheep Summer/Winter Source Habitat Available for Domestic Sheep Use Source habitat contains characteristics that contribute to positive population growth for bighorn sheep. Bighorn may, or may not actually occupy this habitat, and potential use varies by season (summer/winter). Should this habitat be available for domestic sheep use, the potential for contact increases.

- Bighorn Sheep Summer/Winter CHHR Available for Domestic Sheep Use - The CHHR is the area within which most bighorn herd individuals spend at least 95 percent of their time. If the CHHR is available for domestic sheep use, the allotment has a predicted contact rate of one or more interspecies contacts per year, greatly increasing the potential for disease transmission and disease outbreaks. The higher the number of acres of CHHR overlap with domestic sheep allotments, the greater the number of contacts that could occur annually.

- Distance between BLM Land Available for Domestic Sheep Use and Nearest Bighorn Sheep CHHR or Area of Interest - The shorter the distance between allotments available for domestic sheep use and a bighorn CHHR, the greater the likelihood of contact between species.

- Probable Contacts per Year between Domestic and Bighorn Sheep - This is the number of contacts per year predicted between the two species, which is considered a primary factor contributing to potential for disease transmission, disease outbreaks, and population persistence.

- Ranking of Effects on Bighorn Sheep Population Persistence - This is the rank order of the estimated adverse effect on the persistence of affected herds.

- Ranking of Area Available for Bighorn Sheep and Native American Tribal Hunting The rank order of the adverse effects that each alternative would have on the opportunities for Native American Tribal members to hunt for bighorn sheep in traditional or culturally important areas.

- Ranking of Availability of Bighorn Sheep for Native American Tribal Hunting - This is the rank order of the effects that each alternative would have on the opportunities for Native American Tribal members to hunt bighorn sheep, based on bighorn sheep population persistence.

- AUMs Available for Domestic Sheep Use-AUMs are a measure of the forage that would be available for domestic sheep use under each alternative.

- Contributed Jobs - This is an estimate of the number of jobs that the grazing use on the four allotments would contribute to the local economy.

- Ranking of Opportunities for Bighorn Sheep-related Recreation - The rank order of the adverse effects on bighorn sheep-related recreation, such as hunting or wildlife viewing. 


\begin{tabular}{|c|c|c|c|c|c|c|}
\hline \multirow[b]{2}{*}{ Indicator } & \multicolumn{6}{|c|}{ Alternatives } \\
\hline & $\mathbf{A}$ & B & $\mathrm{C}$ & D & E & F \\
\hline $\begin{array}{l}\text { Bighorn Sheep Summer/Winter Souree Habitat } \\
\text { Available for Domestie Sheep Use (aeres) }\end{array}$ & $\begin{array}{l}7,015 \\
4,502\end{array}$ & $\begin{array}{l}1 \\
0\end{array}$ & $\begin{array}{l}0 \\
0\end{array}$ & $\begin{array}{c}1,188 \\
0\end{array}$ & $\begin{array}{c}5,071 \\
0\end{array}$ & $\begin{array}{c}5,640 \\
0\end{array}$ \\
\hline $\begin{array}{l}\text { Bighorn Sheep Summer/Winter CHHR } \\
\text { Available for Domestie Sheep Use (aeres) }\end{array}$ & $\begin{array}{l}8,005 \\
8,008 \\
\end{array}$ & $\begin{array}{l}0 \\
0\end{array}$ & $\begin{array}{l}0 \\
0\end{array}$ & $\begin{array}{l}0 \\
0\end{array}$ & $\begin{array}{c}2,629 \\
0\end{array}$ & $\begin{array}{c}2,629 \\
0\end{array}$ \\
\hline $\begin{array}{l}\text { Distanee between BLM Land Available for } \\
\text { Domestie Sheep Use and Nearest Bighorn } \\
\text { CHHR or Area of Interest (miles) }\end{array}$ & 0.0 & 12.96 & N/A & 1.19 & 0.0 & 0.0 \\
\hline $\begin{array}{l}\text { Probable Contaets per Year between Domestie } \\
\text { and Bighorn Sheep }\end{array}$ & $2.0116+$ & 0.00002 & 0.0000 & 0.07345 & $1.079312+$ & $1.005902+$ \\
\hline $\begin{array}{l}\text { Ranking of Effeets on Bighorn Sheep } \\
\text { Population Persistenee ( } 1=\text { least, } 6=\text { most) }\end{array}$ & 6 & 2 & 1 & 3 & 5 & 4 \\
\hline $\begin{array}{l}\text { Ranking of Area Available for Bighorn Sheep } \\
\text { and Native Ameriean Tribal Hunting (1=most, } \\
6=\text { least) }\end{array}$ & 6 & 2 & 1 & 3 & 4 & 5 \\
\hline $\begin{array}{l}\text { Ranking of Availability of Bighorn Sheep for } \\
\text { Native Ameriean Tribal Hunting ( } 1=\text { most, } \\
6=\text { =east) }\end{array}$ & 6 & 2 & 1 & 3 & 5 & 4 \\
\hline AUMs Available for Domestic Sheep Use & 896 & 81 & 0 & 247 & 465 & 299 \\
\hline Contributed Jobs & 5.1 & 0.4 & 0.0 & 1.4 & 2.6 & 1.7 \\
\hline $\begin{array}{l}\text { Ranking of Opportunities for Bighorn Sheep- } \\
\text { Related Reereation (1=most, } 6=\text { =least) }\end{array}$ & 6 & 2 & 1 & 3 & 5 & 4 \\
\hline
\end{tabular}


This page intentionally left blank. 


\subsection{PROPOSED ACTION}

The Bureau of Land Management (BLM) proposes to amend the Record of Decision and Approved Cottonwood Resources Management Plan (Cottonwood ROD/RMP) (BLM 2009a) by providing new direction for the management and allocations for livestock grazing on 19,405 acres of BLM land within four BLM allotments in Idaho and Adams counties, Idaho (see Map 2 in Appendix D).

\subsection{BACKGROUND}

In August 2008, the BLM published the Proposed Cottonwood Resource Management Plan and Final Environmental Impact Statement (Cottonwood PRMP/FEIS) (BLM 2008b); subsequently receiving a number of protests on the proposed decision. In accordance with federal regulations (43 Code of Federal Regulations [CFR] 1610-5-2), the BLM Director renders a decision on any valid protest to a proposed RMP. In this case, the single protest point granted by the Director pertained to the adequacy of the range of alternatives for the management of domestic sheep grazing on four BLM allotments within bighorn sheep (Orvis canadensis) habitat. In the Protest Resolution Report (BLM 2009b), the Director found that the Cottonwood PRMP/FEIS did not provide an adequate range of alternatives to address potential disease transmission from domestic sheep and goats to bighorn sheep. As such, this portion of the PRMP/FEIS was remanded to the BLM Idaho State Director, requiring that a supplemental EIS (SEIS) be completed that includes a reasonable range of alternatives. The Director further specified that the SEIS would be for the express purpose of analyzing the impacts of domestic sheep and goat grazing within the previously mentioned allotments (Partridge Creek, Marshall Mountain, Hard Creek, and Big Creek allotments).

Currently, no domestic sheep grazing is occurring on any of the four subject allotments. In late 2009, the United States District Court issued a temporary restraining order that closed domestic sheep use of the Partridge Creek Allotment ${ }^{1}$. On March 15, 2011, the Cottonwood Field Manager closed the Marshall Mountain Allotment (BLM 2011a) in accordance with grazing administration regulations found at 43 CFR Part 4100. The grazing lessee for Hard Creek and Big Creek has voluntarily chosen non-use for these two allotments.

\subsection{PURPOSE AND NEED}

Disease transmission from domestic sheep to bighorn sheep has potentially contributed to significant declines in bighorn populations and, in some cases, extirpation. The proposed action is needed because domestic sheep and goat grazing on four BLM allotments (Partridge Creek, Marshall Mountain, Hard Creek, and Big Creek) could result in disease transmission to bighorn sheep and contribute to downward trends of local bighorn populations. As identified in protests

\footnotetext{
${ }^{1}$ U.S. District Court for the District of Idaho, Civ. No. 09-0507-E-BLW, Decision and Order, October 14, 2009.
} 
to the Cottonwood PRMP/FEIS, the BLM must consider this when developing RMP direction for livestock grazing on these four allotments.

The purpose of the proposed action is to provide RMP direction for the management and allocation of livestock grazing on four BLM allotments that includes reasonable means to avoid or mitigate domestic sheep contact with and potential disease transmission to bighorn sheep populations.

\subsection{DECISIONS TO BE MADE}

The BLM Idaho State Director will decide, through an amendment to the Cottonwood ROD/RMP, which areas of BLM land will be available and how much forage will be allocated for livestock grazing, as well as what other management direction is necessary to address potential contact between bighorn sheep, and domestic sheep and goats, and related potential disease transmission to bighorn sheep populations, in the vicinity of or within the Partridge Creek, Marshall Mountain, Hard Creek, and Big Creek allotments. Decisions will be based on direction in the following federal regulations and BLM policy:

43 CFR 4100.0-8 states that "the authorized officer shall manage livestock grazing on public lands under the principle of multiple use and sustained yield, and in accordance with applicable land use plans. Land use plans shall establish allowable resource uses (either singly or in combination), related levels of production or use to be maintained, areas of use, and resource condition goals and objectives to be obtained. The plans also set forth program constraints and general management practices needed to achieve management objectives. Livestock grazing activities and management actions approved by the authorized officer shall be in conformance with the land use plan as defined at 43 CFR 1601.0-5(b)."

The BLM Land Use Planning Handbook (BLM 2005) specifies that land use plan decisions will "identify lands available or not available for livestock grazing..." and "for lands available for livestock grazing, identify on an area-wide basis both the amount of existing forage available for livestock (expressed in animal unit months) and the future anticipated amount of forage available for livestock with full implementation of the land use plan..."

While land use plan/RMP decisions allocate areas and forage for livestock use, they do not authorize use. Authorized use will not be decided by this RMP amendment. As specified in federal regulations, "[g]razing permits and leases authorize use on the public lands and other BLM-administered lands that are designated in land use plans as available for livestock grazing."

\subsection{PLANNING CRITERIA}

Planning criteria guide the development of a plan by helping to define the decision space (or the "sideboards" that define the scope of the planning effort), which is generally based on applicable laws, Director and State Director guidance, and the results of public and governmental participation (43 CFR 1610.4-2). For this RMP amendment process and SEIS the BLM Director and the BLM Idaho State Director provided specific direction in the Protest Resolution Report (BLM 2009b) and the Cottonwood ROD/RMP (BLM 2009a), respectively. In accordance with this direction: 
- This RMP amendment process and SEIS will only address the management of livestock grazing on the four BLM allotments as it relates to potential disease transmission to bighorn sheep populations. The four allotments are Partridge Creek, Marshall Mountain, Hard Creek, and Big Creek. This amendment process and SEIS will not address or modify any other decisions in the 2009 ROD and Approved Cottonwood RMP (BLM 2009).

In addition, the following planning criteria from the Cottonwood PRMP and FEIS (BLM 2008b) also apply to this plan amendment process and SEIS:

- This RMP amendment process and SEIS will comply with all applicable laws, regulations, and current policies. This includes local, state, Tribal, and federal air quality standards, as well as water quality standards from the Idaho Nonpoint Source Management Program Plans.

- The RMP planning effort will be collaborative and multijurisdictional in nature. The BLM will strive to ensure that its management decisions are complementary to other planning jurisdictions and adjoining properties, within the boundaries described by law and federal regulations.

- All previously established Wilderness Study Areas (WSA) will continue to be managed for wilderness values and character until such time as Congress designates them as wilderness areas, or releases them for multiple use management.

- The RMP will recognize all valid existing rights.

\section{DESCRIPTION OF THE PLANNING AREA}

The planning area for this amendment process is limited to the Partridge Creek, Marshall Mountain, Hard Creek, and Big Creek grazing allotments in Idaho and Adams counties, Idaho (see Map 2 in Appendix D). These allotments contain 19,405 acres of BLM-administered land.

\subsection{PLANNING PROCESS}

This RMP Amendment/SEIS process will follow the standard steps for preparing an RMP, as outlined in the BLM Land Use Planning Handbook and as depicted on Figure 1-1 which appears on page 1-6. However, since this is a supplemental EIS, public scoping and publication of a scoping report and analysis of the management situation (AMS) was not necessary. This is indicated by an "X" over each of these items in Figure 1-1. The BLM considered public comments from the Draft Cottonwood RMP/EIS and protests to the Cottonwood PRMP/FEIS to identify planning issues (see Section 1.8 below), All supplemental information and analysis are documented in this SEIS, which would make a new AMS redundant. 


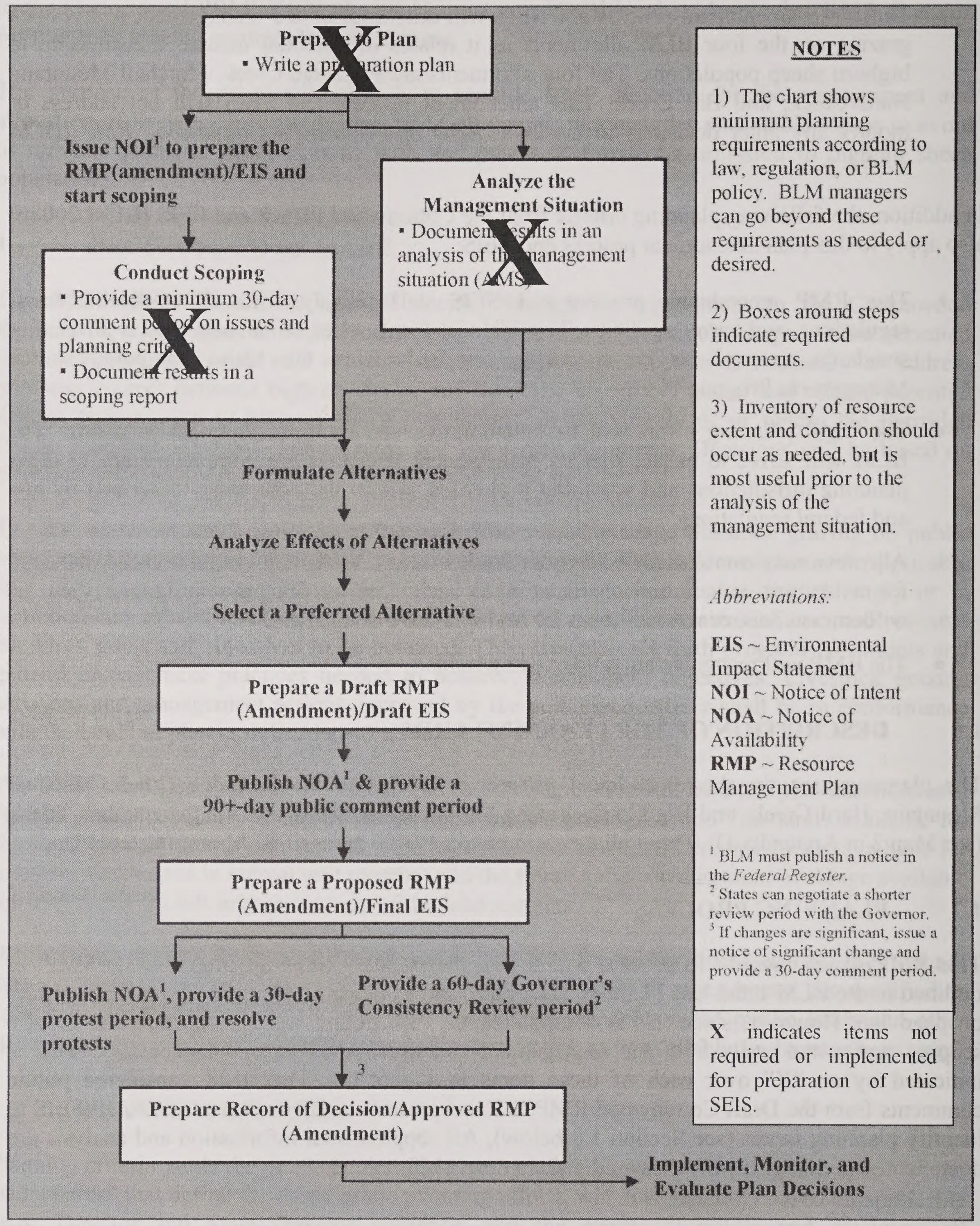

Figure 1-1: $\quad$ Steps for the Preparation of an RMP 


\subsection{PLANNING ISSUES}

A supplemental EIS is prepared with the same requirements as a stand-alone EIS, with the exception that a supplemental EIS does not require scoping (40 CFR 1502.9(c)). For this SEIS, the BLM published a Notice of Intent on March 12, 2010, in the Federal Register. In October 2011, the Cottonwood Field Office (CFO) completed a Scoping. Report and mailed out a newsletter to update the public on the status of the SEIS.

The BLM identified planning issues through a collaborative scoping process with other governmental agencies and the Nez Perce Tribe. These planning issues are:

- Bighorn Sheep - Domestic sheep and goats may contact and transmit diseases to bighorn sheep, possibly contributing to the downward trend in populations.

- Native American Tribal Interests and Treaty Rights - Management of livestock grazing by the BLM, specifically domestic sheep and goats, may affect the availability of resources and uses specifically related to bighorn sheep and that are important to the interests and rights of the Nez Perce Tribe.

- Livestock Grazing and Social and Economic Interests - Changes to management of livestock grazing by the BLM may affect the local economy.

\subsection{COLLABORATION}

Section 202(c)(9) of the Federal Land Policy and Management Act of 1976 (FLPMA) requires the BLM, to the extent consistent with applicable federal laws, to coordinate its planning and management actions with similar planning and management actions of other federal, state, and local agencies and Tribal governments. In July 2010, the Payette National Forest and Nez Perce Tribe accepted invitations to participate in preparation of this SEIS as cooperating agencies. In March 2012, the BLM, Nez Perce Tribe, and Payette National Forest signed a formal cooperating agency agreement.

Section 202(c)(9) of the FLPMA further requires the BLM to ensure that consideration is given to those state, local, and Tribal plans that are germane to the development of land use plans for public lands and that assist in resolving, to the extent practical, any inconsistencies between federal and non-federal government plans.

Consistent with FLPMA, the BLM has coordinated with the Nez Perce Tribe, taking into consideration the Tribe's policies regarding management of bighorn sheep. Specifically, the BLM considered the Tribe's policy as described in their letter of protest for the 2008 Cottonwood PRMP/FEIS, including:

- Adopt a recovery goal for bighorn sheep, of healthy, self-sustaining numbers, welldistributed across historic habitats in Hells Canyon and the Salmon River to ensure longterm conservation and support treaty harvest across age and sex classes. 
- Establish a Tribal standard of no contact between bighorn sheep and domestic sheep and encourage the federal land managers to adopt standard that would prohibit domestic sheep grazing within or adjacent to occupied bighorn sheep habitat.

- Establish Tribal standard of using buffers to create space between occupied bighorn sheep habitat and domestic sheep grazing and encourage federal land managers to do the same.

- Adopt a Tribal standard of promoting bighorn sheep restoration and expansion across historic habitats within Hells Canyon and the Salmon River.

The above administrative actions "provide a Tribal policy framework for promoting healthy, harvestable population recovery goals for bighorn sheep, and encourages federal land managers to adopt these policies in accordance with the United States' treaty and trust responsibilities to the Nez Perce Tribe" (Nez Perce Tribe 2008).

The BLM also coordinated with the Payette National Forest and Idaho Department of Fish and Game (IDFG) regarding the following non-BLM plans:

- Record of Decision for the Final SEIS, and Forest Plan Amendment Identifying Suitable Rangeland for Domestic Sheep and Goat Grazing to Maintain Habitat for Viable Bighorn Sheep Populations (USFS 2010b)

- Idaho Bighorn Sheep Management Plan (IDFG 2010)

In addition to the above requirements and compliance measures, this PRMP/FEIS will be subject to a Governor's Consistency Review (pursuant to 43 CFR 1610.3-2).

The BLM is also a partner in the Salmon River Bighorn Sheep Project, an interagency research effort established for the purpose of gaining a better ecological understanding of bighorn sheep in the Salmon River Canyon, which is specific to the Main Salmon/South Fork herd. Additional partners include the Nez Perce Tribe, IDFG, Payette National Forest, and Nez Perce National Forest. The project area includes a 75-mile portion of the Salmon River drainage in Idaho from the town of Riggins, east upriver to the confluence of Big Mallard Creek. Major tributaries within the project area include the lower portions of the Little Salmon and South Fork Salmon rivers.

The BLM also participates in the Hells Canyon Initiative, a state, federal, and private partnership established in 1995 to restore Rocky Mountain bighorn sheep in the Hells Canyon area of Oregon, Idaho, and Washington. The concept was formalized in 1997 with the completion of an interagency memorandum of agreement and restoration plan. Additional partners include IDFG, Oregon Department of Fish and Wildlife (ODFW), Washington Department of Fish and Wildlife (WDFW), and the Wild Sheep Foundation.

The BLM also collaborated with other stakeholders through the Wild Sheep Working Group of the Western Association of Fish and Wildlife Agencies (WAFWA) in developing Recommendations for Domestic Sheep and Goat Management in Wild Sheep Habitat (WAFWA 2012). For the state of Idaho, the Wild Sheep Working Group guidelines are included in the Interim Strategy for Managing Separation between Bighorn Sheep and Domestic Sheep in Idaho 
(IDFG 2007) and the Idaho Bighorn Sheep Management Plan (IDFG 2010). Although the BLM took these guidelines into consideration in developing the alternatives in this SEIS, the BLM has not formally adopted them.

\subsection{POLICY}

The RMP amendment must be consistent with the following policies:

- Land Use Planning Handbook (BLM 2005) - Outlines requirements and procedures for developing and amending RMPs.

- National Environmental Policy Act Handbook (BLM 2008a) - Outlines requirements and procedures for compliance with the NEPA and CEQ Regulations.

- Manual 6500, Wildlife and Fisheries Management (BLM 1988) - Outlines BLM policy for the wildlife and fisheries program, as well as identifies a general goal to "ensure optimum population and a natural abundance and diversity of wildlife resources on public lands by restoring, maintaining, and enhancing habitat conditions through management plans and action integrated with other uses of public lands, through coordination with other programs, the States, by management initiatives, and through direct habitat improvement projects." It also identifies a specific goal for big game/upland game habitat management "to ensure that big game/upland game species on the public lands are provided habitat of sufficient quantity and quality to sustain identifiable economic and/or social contributions to the American people."

- Manual 8120, Tribal Consultation Under Cultural Resource Authorities - Outlines policy for BLM Tribal consultation. One of the objectives is to "ensure that Tribal issues and concerns are given legally adequate consideration during decision making."

- BLM Idaho Instruction Memorandum 2011-004 (BLM 2011b), Separation Response Plans for Bighorn Sheep and Domestic Sheep and Goats - Requires BLM offices in Idaho to complete and implement separation response plans for all grazing allotments that authorize domestic sheep or goat use, and other areas where bighorn sheep could come into contact with domestic sheep and goats on BLM public lands. 
This page intentionally left blank. 
This page intentionally left blank. 


\subsection{INTRODUCTION}

Chapter 2 describes the reasonable range of alternatives for amending the Approved Cottonwood RMP (BLM 2009) designed specifically to address potential disease transmission to bighorn sheep populations that could result from domestic sheep and goat grazing in the Big Creek, Hard Creek, Partridge Creek, and Marshall Mountain allotments. As stated in Section 1.5, this amendment process does not address or modify any other decisions in the 2009 Cottonwood ROD/RMP.

\subsection{DECISIONS FROM THE APPROVED COTTONWOOD ROD/RMP WITH BEARING ON THE ALTERNATIVES}

The following decisions from the 2009 Cottonwood ROD/RMP, while not subject to modification, have bearing on or are related to the alternatives for the amendment:

Wildlife Goal WS-1: Manage habitat to contribute to the conservation of special status species habitats and maintain biological diversity of wildlife.

- Objective WS-1.6-Manage rangeland and forest vegetation to provide for diversity, cover, structure, forage, and security to contribute to healthy populations of rangeland and forest dependent species and other wildlife.

- Objective WS-1.10-Maintain or restore Rocky Mountain bighorn sheep (Ovis canadensis canadensis) habitat.

- Action WS-1.10.2 - Coordinate with the State of Idaho, including the Department of Fish and Game and other appropriate state agencies, the Nez Perce Tribe, U.S. Forest Service (USFS), and other appropriate federal agencies, grazing lessees, and partners on population and habitat management of bighorn sheep.

- Action WS-1.10.3 - No existing allotments authorized for cattle and/or horse use within the Salmon River and/or Snake River drainages will be converted to sheep or goats, when such use would result in potential risk for disease transmission to bighorn sheep populations or affect the potential for bighorn sheep expansion into suitable habitats.

- Action WS-1.10.4 - Goat grazing for weed control is prohibited in Hells Canyon (Snake River drainage), downriver from Maloney Creek (Salmon River drainage), and upriver from Little Salmon River (Salmon River drainage). In other areas, goat grazing for weed control will only be authorized when such use will result in no or very low risk for transmission of disease to bighorn sheep.

- Action WS-1.10.5-Support cooperative bighorn sheep studies and research within the Snake and Salmon River drainages that provide improved or updated habitat, distribution, and management information. Cooperate with survey and monitoring projects that document bighorn sheep observations, telemetry locations, and 
population ranges within the Snake and Salmon River canyons, tributary drainages, and associated uplands.

Livestock Grazing Goal LS-1: Provide opportunities for livestock grazing while meeting rangeland health standards.

- Objective LG-1.1-Identify lands available for livestock grazing.

Native American Tribal Uses Goal NA-1: Manage natural and cultural resources consistent with treaty and trust responsibilities to Native American tribes.

- Objective LG-1.1-Maintain and, where possible, improve natural and cultural resource conditions to enhance opportunities to exercise Native American traditional uses.

- Action NA-1.1.1 - Consult with Native American tribes to identify culturally significant plants, animals, fish, and important habitats.

\subsection{DESCRIPTIONS OF THE ALTERNATIVES}

The BLM developed five action alternatives to meet the purpose and need. In addition, for analysis purposes, the BLM included a No Action alternative. These alternatives are described below.

\subsubsection{Common to All Alternatives}

Because this amendment specifically focuses on addressing the impacts of potential disease transmission from domestic sheep and goats to bighorn sheep, none of the alternatives closes the allotments to other types of livestock grazing (e.g., cattle, horses, etc.). Therefore, under all Alternatives, all four allotments and specified forage would be available for grazing by other types of livestock. This would include allotments and forage that are not available for domestic sheep or goat grazing under the action alternatives Table 2-1 presents these allocations by allotment.

Table 2-1: $\quad$ Livestock Grazing Allocations Common to All Alternatives

\begin{tabular}{|l|c|c|}
\hline \multicolumn{1}{|c|}{ Allotment Name } & Acres Allocated & Forage Allocated (AUMs) \\
\hline Partridge Creek & 9,544 & 431 \\
\hline Marshall Mountain & 4,212 & 166 \\
\hline Hard Creek & 5,210 & 218 \\
\hline Big Creek & 439 & 81 \\
\hline Total Allocation & $\mathbf{1 9 , 4 0 5}$ & $\mathbf{8 9 6}$ \\
\hline
\end{tabular}

Please note that these allocations are not authorizations. As stated in Section 1.4, this RMP amendment does not authorize livestock grazing. Actual area, season of use, and animal unit months (AUM) authorized for use will be determined through site-specific analysis for grazing leases for these allotments, which must be consistent with the management direction in the RMP as amended when a decision is signed for this planning effort. 
For any of the four allotments where domestic sheep are allowed to grazed, the BLM would develop a separation response plan for bighorn sheep and domestic sheep. The response plan would define the process, protocols, and timelines for short-term or emergency management actions when specific actions are needed to minimize risk of co-mingling and contact between bighorn sheep and domestic sheep.

The BLM would develop a strategy to monitor or survey for bighorn sheep in proximity to domestic sheep allotments, to be included in the separation response plan. Monitoring and survey intensity would be dependent on proximity to core herd home ranges and source habitats occurring within and adjacent to allotment. Monitoring and surveys may be conducted by state or other federal agencies, tribes, or other partnerships. The resulting survey and monitoring data would provide updated bighorn sheep distribution and population information and provide for adaptive management needs for conservation of bighorn sheep and minimizing potential contact with domestic sheep and goats.

\subsubsection{Alternative A - No Action Alternative}

Under this alternative, the BLM would take no action. Since the Cottonwood ROD/RMP did not address livestock grazing on these four allotments, the grazing decisions from the Chief Joseph Management Framework Plan (MFP) (BLM 1981) and the North Idaho Grazing EIS/ROD (BLM 1982) would remain in effect. The area and forage allocations shown in Table 2-1 would be available for domestic sheep (see Map 5 in Appendix D). The MFP did not address domestic goat grazing. Council on Environmental Quality (CEQ) regulations direct that an EIS describe the No Action alternative (40 CFR 1502.14(d)), which is the only alternative that must be analyzed that does not respond to a proposed project's purpose and need. The No Action alternative provides a baseline for comparison of environmental effects and demonstrates the consequences of not meeting the purpose and need for the action.

\subsubsection{Alternative B - Preferred Alternative}

Alternative B, the BLM's preferred alternative, emphasizes reducing the potential for transmission of disease to bighorn sheep while providing some opportunity for grazing of domestic sheep, based on consideration of the proximity of the allotments to core herd home ranges (CHHR) and risk of contact between domestic sheep and goats and bighorn sheep (see Map 5 in Appendix D). The preferred alternative would prohibit domestic sheep and goat grazing on all allotments except Big Creek (Table 2-2). The terms and conditions in Appendix C would be added to the grazing lease for the Big Creek Allotment to reduce the potential for contact between domestic sheep or goats and bighorn sheep; or, at the time of lease renewal, the BLM will explain why specific terms and conditions would not be applied and/or why other terms and conditions to reduce potential for contact, not listed in Appendix C, would be required. 
Table 2-2: $\quad$ Alternative B Allocations Available for Domestic Sheep Grazing

\begin{tabular}{|l|c|c|}
\hline \multicolumn{1}{|c|}{ Allotment Name } & Acres Available & Forage Available (AUMs) \\
\hline Partridge Creek & 0 & 0 \\
\hline Marshall Mountain & 0 & 0 \\
\hline Hard Creek & 0 & 0 \\
\hline Big Creek & 439 & 81 \\
\hline Total & $\mathbf{4 3 9}$ & $\mathbf{8 1}$ \\
\hline
\end{tabular}

\subsubsection{Alternative C-Eliminate Domestic Sheep and Goat Grazing}

Alternative $\mathrm{C}$ would eliminate contact between domestic sheep or goats and bighorn sheep, and the associated potential for disease transmission, by prohibiting domestic sheep and goat grazing on all of the four allotments (see Map 5 in Appendix D).

\subsubsection{Alternative D - Restrict Grazing on Partridge Creek and Hard Creek}

Alternative D was developed to reduce the potential for contact and disease transmission in the Main Salmon/South Fork CHHR (Partridge Creek Allotment) and Little Salmon area of concern (Hard Creek Allotment). Domestic sheep and goat grazing would be prohibited on the Partridge Creek and Hard Creek allotments (see Map 5 in Appendix D; Table 2-3).

Table 2-3: $\quad$ Alternative D Allocations Available for Domestic Sheep Grazing

\begin{tabular}{|l|c|c|}
\hline \multicolumn{1}{|c|}{ Allotment Name } & Acres Available & Forage Available (AUMs) \\
\hline Partridge Creek & 0 & 0 \\
\hline Marshall Mountain & 4,212 & 166 \\
\hline Hard Creek & 0 & 0 \\
\hline Big Creek & 439 & 81 \\
\hline Total & $\mathbf{4 , 6 5 1}$ & $\mathbf{2 4 7}$ \\
\hline
\end{tabular}

\subsubsection{Alternative $\mathbf{E}$ - Restrict Grazing on Partridge Creek Only}

Alternative $\mathrm{E}$ was developed to eliminate the highest risk of contact by prohibiting domestic sheep and goat grazing on the Partridge Creek Allotment (see Map 5 in Appendix D; Table 2-4). The Partridge Creek Allotment is the only allotment that overlaps with the Main Salmon/South Fork CHHR.

Table 2-4: $\quad$ Alternative E Allocations Available for Domestic Sheep Grazing

\begin{tabular}{|l|c|c|}
\hline \multicolumn{1}{|c|}{ Allotment Name } & Acres Available & Forage Available (AUMs) \\
\hline Partridge Creek & 0 & 0 \\
\hline Marshall Mountain & 4,212 & 166 \\
\hline Hard Creek & 5,210 & 218 \\
\hline Big Creek & 439 & 81 \\
\hline Total & $\mathbf{9 , 8 6 1}$ & $\mathbf{4 6 5}$ \\
\hline
\end{tabular}




\subsubsection{Alternative F - Restrict Grazing on Partridge Creek and Marshall Mountain}

Alternative $\mathrm{F}$ emphasizes the elimination of potential contact in the Main Salmon/South Fork bighorn herd (see Map 5 in Appendix D) by prohibiting the grazing of domestic sheep or goats on the Partridge Creek and Marshall Mountain allotments; however, domestic sheep grazing could continue at its current levels on the Hard Creek and Big Creek allotments which occur in the Little Salmon River drainage (Table 2-5).

Table 2-5: $\quad$ Alternative F Allocations Available for Domestic Sheep Grazing

\begin{tabular}{|l|c|c|}
\hline \multicolumn{1}{|c|}{ Allotment Name } & Acres Available & Forage Available (AUMs) \\
\hline Partridgé Creek & 0 & 0 \\
\hline Marshall Mountain & 0 & 0 \\
\hline Hard Creek & 5,210 & 218 \\
\hline Big Creek & 439 & 81 \\
\hline Total & $\mathbf{5 , 6 4 9}$ & $\mathbf{2 9 9}$ \\
\hline
\end{tabular}

\subsubsection{Summary of Alternatives}

Table 2-6 and Table 2-7 summarize the livestock grazing allocations available for domestic sheep for all six alternatives.

\begin{tabular}{|l|c|c|c|c|c|c|}
\hline Table 2-6: & Acres Available for Domestic Sheep by Alternative \\
\hline \multicolumn{1}{|c|}{ Allotment } & Alternative A & Alternative B & Alternative C & Alternative D & Alternative E & Alternative F \\
\hline Partridge Creek & 9,544 & 0 & 0 & 0 & 0 & 0 \\
\hline Marshal Mountain & 4,212 & 0 & 0 & 4,212 & 4,212 & 0 \\
\hline Hard Creek & 5,210 & 0 & 0 & 0 & 5,210 & 5,210 \\
\hline Big Creek & 439 & 439 & 0 & 439 & 439 & 439 \\
\hline Total & $\mathbf{1 9 , 4 0 5}$ & $\mathbf{4 3 9}$ & $\mathbf{0}$ & $\mathbf{4 , 6 5 1}$ & $\mathbf{9 , 8 6 1}$ & $\mathbf{5 , 6 4 9}$ \\
\hline
\end{tabular}

Table 2-7: $\quad$ Animal Unit Months Available for Domestic Sheep by Alternative

\begin{tabular}{|l|c|c|c|c|c|c|}
\hline \multicolumn{1}{|c|}{ Allotment } & Alternative A & Alternative B & Alternative C & Alternative D & Alternative E & Alternative F \\
\hline Partridge Creek & 431 & 0 & 0 & 0 & 0 & 0 \\
\hline Marshal Mountain & 166 & 0 & 0 & 166 & 166 & 0 \\
\hline Hard Creek & 218 & 0 & 0 & 0 & 218 & 218 \\
\hline Big Creek & 81 & 81 & 0 & 81 & 81 & 81 \\
\hline Total & $\mathbf{8 9 6}$ & $\mathbf{8 1}$ & $\mathbf{0}$ & $\mathbf{2 4 7}$ & $\mathbf{4 6 5}$ & $\mathbf{2 9 9}$ \\
\hline
\end{tabular}

\subsection{ALTERNATIVES CONSIDERED BUT ELIMINATED FROM DETAILED STUDY}

The BLM considered other alternatives based on public comments and scoping with cooperators, but eliminated them from further analysis. Following is a description of these alternatives and the reasons for their elimination. 


\subsubsection{Alternative G-9-mile Buffer}

To reduce a potential for contact, the BLM considered establishing a 9-mile buffer between areas available for domestic sheep or goat grazing and for bighorn sheep herds, but eliminated it from detailed analysis because it is essentially the same as Alternative B, the preferred alternative. In a past policy (BLM 1998) the BLM recommended a minimum 9-mile buffer between herds or populations of bighorn sheep and domestic sheep allotments to ensure effective separation. Although this is no longer BLM policy, it is a method worthy of consideration. However, of the four allotments, domestic sheep grazing would only be allowed in the Big Creek Allotment because it is the only one that is more than 9 miles from any herd home range. Partridge Creek, Marshal Mountain, and Hard Creek allotments are within 9 miles of CHHR, and therefore, domestic sheep and goat grazing would be prohibited on all of these allotments. Thus, Alternative $\mathrm{G}$ is essentially the same as Alternative B, which prohibits domestic sheep and goat grazing on Partridge Creek, Marshall Mountain, and Hard Creek allotments.

\subsubsection{Alternative H - 1-mile Source Habitat Buffer}

To reduce a potential for contact near bighorn summer and winter source habitats (see maps 6 and 7 in Appendix D), the BLM considered prohibiting domestic sheep or goat grazing within 1 mile of these habitats (buffer based on distance from source habitats, not herd home ranges as in Alternative G). Alternative $\mathrm{H}$ was eliminated from detailed study because it is also the same as Alternative B, the preferred alternative. Implementing this 1-mile buffer would prohibit domestic sheep and goat grazing on the Partridge Creek, Marshal Mountain, and Hard Creek allotments. However, domestic sheep and goat grazing would be permitted on most of the Big Creek Allotment. Alternative $\mathrm{H}$ is essentially the same as Alternative B, which prohibits domestic sheep and goat grazing on the same allotments.

\subsubsection{Alternative I-20-mile Buffer}

The BLM considered establishing a 20-mile buffer between areas available for domestic sheep or goat grazing and for bighorn sheep CHHRs. Alternative I was eliminated from detailed analysis because it is the same as Alternative C. Under Alternative I, domestic sheep and goat grazing would be prohibited on all 4 of the allotments, because all are within the 20 -mile buffer, essentially making Alternative I the same as Alternative C, which prohibits domestic sheep and goat grazing on all four allotments.

\subsubsection{Alternative $\mathbf{J}$-Geographic Boundaries}

The BLM developed Alternative $\mathbf{J}$ to help determine if geographic boundaries (e.g., watersheds) could be used to separate domestic sheep or goats from bighorn sheep to reduce contact, but this was eliminated from detailed analysis. Under this alternative, the lessee would need to use topographic and landscape features as barriers to prevent or minimize potential contact. Because the BLM determined that there are no geographic features that could effectively serve this purpose, Alternative $J$ was deemed to be not practical or feasible to implement. 


\subsubsection{Alternative K-Designate Bighorn as a BLM Sensitive Species}

The Nez Perce Tribe has requested that the BLM designate bighorn sheep as a sensitive species in Idaho. However this type of decision is outside the scope of an RMP amendment, thereby eliminating Alternative $\mathrm{K}$ from detailed analysis in this SEIS. Through a separate process, the BLM-Idaho State Office has committed to collaborating in the future with the IDFG and U.S.

Fish and Wildlife Service regarding this request, along with nearly 100 other requests for sensitive plant and animal listings. Due to recent budget shortfalls and limited staffing these requests are taking much longer to analyze and process than anticipated.

\subsubsection{Alternative L-Allow Domestic Sheep and Goat Grazing on All Allotments with Leasing Terms and Conditions to Reduce Potential Interspecies Contact}

The BLM considered an alternative that would make all four allotments available for domestic sheep and goat grazing with application of the leasing terms and conditions identified in Appendix $\mathrm{C}$ to reduce the potential for contact with bighorn sheep. These terms and conditions have previously been identified, recommended, or implemented by the USFS and the BLM as best management practices (BMPs). However, when bighorn sheep CHHR occur in or adjacent to a domestic sheep allotment, and especially when the allotment is within bighorn herd home range, development and implementation of effective separation measures is difficult; and contact between the species will most likely still occur. Furthermore, even with these extra measures, control of domestic sheep or monitoring and locating bighorn sheep in forested or dense vegetation, steep, or rocky and rugged terrain that do not have a large buffer between the two species would not result in a significant reduction in the risk of contact (Schommer 2009). Section 4.2.2.5 contains a more detailed review of the effectiveness of BMPs.

The Partridge Creek and Hard Creek allotments are within, and the Marshall Mountain Allotment is adjacent to, bighorn sheep CHHR. The terrain on all three of these allotments is interspersed with dense vegetation and forested areas with areas that are steep, rocky, and rugged. Therefore, application of the specified terms and conditions on these allotments would likely be ineffective at significantly reducing the potential for contact between bighorn sheep and domestic sheep. Hence, for the Partridge Creek, Hard Creek, and Marshall Mountain Allotments, this alternative would be effectively the same as Alternative A under which all four allotments would be available for domestic sheep grazing but without specified terms and conditions. Differing from the other three allotments, the Big Creek Allotment is not in or near bighorn sheep CHHR and has more open and moderately sloped rangeland. However, for this allotment, this alternative would be essentially the same as Alternatives B, which also makes Big Creek available for domestic sheep or goat grazing with application of the terms and conditions. Therefore this alternative was not analyzed in detail.

\subsection{SUMMARY COMPARISON OF IMPACTS}

Following is a brief explanation of each of the key indicators of impacts that the BLM analyzed as described in Chapter 4. Table 2-8 summarizes the results of this analysis (see Chapter 4 for more detailed explanations regarding methods and results of analysis): 
- Bighorn Sheep Summer/Winter Source Habitat Available for Domestic Sheep Use Source habitat contains characteristics that contribute to positive population growth for bighorn sheep, which may or may not actually occupy this habitat. Potential use varies by season (summer/winter). Should this habitat be available for domestic sheep use, the potential for contact increases.

- Bighorn Sheep Summer/Winter CHHR Available for Domestic Sheep Use - The CHHR is the area within which most bighorn herd individuals spend at least 95 percent of their time. Should a CHHR be available for domestic sheep use, the allotment has a predicted contact rate of one or more $(1+)$ interspecies contacts per year, thus contributing to potential disease transmission and disease outbreaks. The higher the number of acres of CHHR overlap with domestic sheep allotments, the greater the number of contacts that could occur annually.

- Distance between BLM Lands Available for Domestic Sheep Use and Nearest Bighorn Sheep CHHR or Area of Interest -This is the distance between lands within BLM allotments that would be available for domestic sheep grazing and the nearest CHHR. The shorter the distance, the greater the likelihood of contact between species.

- Probable Contacts per Year between Domestic and Bighorn Sheep - This is the number of contacts per year predicted between the two species, which is considered a primary factor contributing to potential disease transmission, disease outbreaks, and population persistence.

- Ranking of Effects on Bighorn Sheep Population Persistence - This is the rank order of the estimated adverse effects on the persistence of affected herds.

- Ranking of Area Available for Bighorn Sheep and Native American Tribal Hunting This is the rank order of the estimated adverse effects that each alternative would have on the opportunities for Native American Tribal members to hunt for bighorn sheep in traditional or culturally important areas.

- Ranking of Availability of Bighorn Sheep for Native American Tribal Hunting - This is the rank order of the adverse effects that each alternative would have on the opportunities for Native American Tribal members to hunt bighorn sheep, based on bighorn sheep population persistence.

- AUMs Available for Domestic Sheep Use - AUMs are a measure of the forage that would be available for domestic sheep use under each alternative.

- Contributed Jobs - This is an estimate of the number of jobs that the grazing use permitted under each alternative would contribute to the local economy.

- Ranking of Opportunities for Bighorn Sheep-related Recreation - This is the rank order of the adverse effects of each alternative on bighorn sheep related recreation, such as hunting or wildlife viewing. 
Table 2-8: Comparative Summary of Impacts from the Alternatives

\begin{tabular}{|c|c|c|c|c|c|c|}
\hline \multirow[b]{2}{*}{ Indicator } & \multicolumn{6}{|c|}{ Alternatives } \\
\hline & A & B & $\mathrm{C}$ & D & $\mathbf{E}$ & $\mathbf{F}$ \\
\hline $\begin{array}{l}\text { Bighorn Sheep Summer/Winter Source } \\
\text { Habitat Available for Domestie Sheep } \\
\text { Use (acres) }\end{array}$ & $\begin{array}{l}7,015 \\
4,502\end{array}$ & $\begin{array}{l}1 \\
0\end{array}$ & $\begin{array}{l}0 \\
0\end{array}$ & $\begin{array}{c}1,188 \\
0\end{array}$ & $\begin{array}{c}5,071 \\
0\end{array}$ & $\begin{array}{c}5,6409 \\
0\end{array}$ \\
\hline $\begin{array}{l}\text { Bighorn Sheep Summer/Winter Core } \\
\text { Herd Home Range Available for } \\
\text { Domestie Sheep Use (aeres) }\end{array}$ & $\begin{array}{l}8,005 \\
8,008\end{array}$ & $\begin{array}{l}0 \\
0\end{array}$ & $\begin{array}{l}0 \\
0\end{array}$ & $\begin{array}{l}0 \\
0\end{array}$ & $\begin{array}{c}2,629 \\
0\end{array}$ & $\begin{array}{c}2,629 \\
0\end{array}$ \\
\hline $\begin{array}{l}\text { Distance-between BLM Lands Available } \\
\text { for Domestic Sheep Use and Nearest } \\
\text { Bighorn Core Herd Home Range or Area } \\
\text { of Coneern (miles) }\end{array}$ & 0.0 & 12.96 & N/A & 1.19 & 1.19 & 0.0 \\
\hline $\begin{array}{l}\text { Probable Contaets per Year between } \\
\text { Domestic and Bighorn Sheep }\end{array}$ & $2.0116+$ & 0.00002 & 0.0000 & 0.07345 & $1.079312+$ & $1.005902+$ \\
\hline \begin{tabular}{|l|} 
Ranking of Effeets on Bighorn Sheep \\
Population Persistenee (1=least, $6=$ most)
\end{tabular} & 6 & 2 & 1 & 3 & 5 & 4 \\
\hline $\begin{array}{l}\text { Ranking of Area Available for Bighorn } \\
\text { Sheep and Native Ameriean Tribal } \\
\text { Hunting ( } 1=\text { most, } 6=\text { least })\end{array}$ & 6 & 2 & 1 & 3 & 4 & 5 \\
\hline $\begin{array}{l}\text { Ranking of Availability of Bighorn Sheep } \\
\text { for Native Ameriean Tribal Hunting } \\
(1=\text { most, } 6 \text { =least })\end{array}$ & 6 & 2 & 1 & 3 & 5 & 4 \\
\hline $\begin{array}{l}\text { AUMs Available for Domestic Sheep } \\
\text { Use }\end{array}$ & 896 & 81 & 0 & 247 & 465 & 299 \\
\hline Contributed Jobs & 5.1 & 0.4 & 0.0 & 1.4 & 2.6 & 1.7 \\
\hline $\begin{array}{l}\text { Ranking of Opportunities for Bighorn } \\
\text { Sheep Related Reereation ( } 1=\text { most, } \\
6=\text { least) }\end{array}$ & 6 & 2 & 1 & 3 & 5 & 4 \\
\hline
\end{tabular}

\subsection{RATIONALE FOR THE IDENTIFICATION OF THE PREFERRED ALTERNATIVE}

The BLM has identified Alternative B as the preferred alternative. In making this identification, the BLM considered the multiple-use and sustained yield mandate, the purpose and need for this RMP Amendment/SEIS, the planning issues, and the results of the effects analysis as described in Chapter 4. The BLM preliminarily found that Alternative B provides a means to allow compatible multiple uses to occur (domestic sheep grazing and bighorn sheep habitat) with low potential for adverse effects to bighorn sheep populations.

BLM Planning Regulations (43 CFR 1610.4-7) require identification of the preferred alternative in a draft EIS for an RMP; or in this case, for the draft SEIS for an RMP Amendment. The preferred alternative is identified to inform the public of the agency's orientation; it does not constitute a commitment or decision in principle, and there is no requirement to select the preferred alternative in the ROD. 
This page intentionally left blank. 
This page intentionally left blank. 


\section{$3.1 \quad$ INTRODUCTION}

This chapter supplements Chapter 3 of the Cottonwood PRMP/FEIS (BLM 2008b) and focuses on the affected environment as it relates to the specific planning issues previously described in Section 1.8 of this SEIS. These issue topics are:

- Bighorn Sheep

- Native American Tribal Interests and Treaty Rights

- Livestock Grazing and Social and Economic Interests

\subsection{BIGHORN SHEEP}

This section supplements Section 3.2.9 of the 2008 PRMP/FEIS and focuses on the following issue: Domestic sheep and goats may contact and transmit diseases to bighorn sheep, which may be a contributing factor to the downward trend in populations.

\subsubsection{Background}

The FLPMA specifically identifies wildlife as one of the resources for which the public lands will be managed. The BLM manages wildlife habitat, as it relates to this SEIS, in coordination with the State of Idaho and the Nez Perce Tribe. The components of habitat management by the BLM includes space, food, shelter, and water. The space component is particularly critical when two species such as bighorn sheep and domestic sheep or goats should not share the same space at the same time due to potential for disease transmission.

The planning area occurs in close proximity to the Payette National Forest, for which a Final Supplemental EIS (Payette FSEIS) (USFS 2010a) was completed to address grazing of domestic sheep within or near the range of bighorn sheep. Portions of this section of BLM's SEIS were derived from and/or summarizes information from the Payette FSEIS.

\subsubsection{Existing Conditions}

Bighorn sheep tend to occur in groups of interacting local populations or herds (the terms herd and population are interchangeable in this SEIS). Interacting populations are often referred to as metapopulations (IDFG 2010). Each metapopulation is composed of discrete local populations that interact with each other as a result of limited movement between the local populations (Bleich et al. 1996; Singer et al. 2000a). The fragmented nature of sheep habitat and the relatively small size of most bighorn sheep herds suggest that bighorn sheep evolved with a metapopulation structure in which small, local populations would not persist without movement and reproduction among herds (Gilpin and Hanski 1989; Berger 1990; Bleich et al. 1990). A large amount of contact and exchange of individuals may occur between some of the local herds identified in this document, while others are fairly isolated. 
Due to the nature of metapopulations and the high dispersal and roaming characteristics of this species, bighorn sheep in proximity or adjacent to BLM domestic sheep allotments may be affected by BLM grazing management actions. The metapopulation structure of bighorn sheep and the long-distance periodic movements among populations (i.e., forays) are well documented. For example, sheep with geographically separate winter ranges have been observed sharing summer ranges (Akenson and Akenson 1992). These interactions can have positive effects, such as population augmentation, colonization, and enhancement of genetic diversity; however, negative effects, such as disease transmission, can also occur. Bighorn sheep ewes can travel as far as 24.8 miles from winter ranges to lambing areas. On BLM land in Idaho, bighorn sheep rams were documented to have traveled as far as 50 miles through towns and across major rivers (Coggins 2002). Telemetry data has shown that desert bighorn sheep regularly cross the broad valleys that separate the majority of desert mountain ranges (Ough and deVos 1984; Schwartz et al. 1986; Jaeger 1994). These complex spatial and temporal range use patterns occur among populations of sheep with resulting effects on forage and vulnerability to disease and parasite transmission (Akenson and Akenson 1992). The presence of dispersal corridors between suitable patches of habitat, and the ability of sheep to move between patches, influences their ability to disperse into suitable but unoccupied habitats (Noss 1987; Simberloff and Cox 1987; Hudson 1991; Douglas and Leslie 1999).

\subsubsection{Analysis Area}

The analysis area for direct and indirect effects to bighorn sheep in this SEIS includes the Hells Canyon and Salmon River metapopulations, and focuses on six herds and one area of concern (Little Salmon) within these metapopulations that occur in proximity (within 35 air-miles) to the four domestic sheep allotments (planning area). The cumulative effects analysis area includes the Upper Hells Canyon, Myers, Muir, Big Canyon, and Sheep Mountain herds in Hells Canyon; Main Salmon/South Fork herd; Little Salmon area of concern; and the four domestic sheep allotments. The herd cumulative effects analysis area includes the specific CHHR and foray analysis area. The cumulative effects analysis area is primarily based on: 1) the probability that foraying bighorn sheep may come in contact with domestic sheep or goat grazing areas, 2) interspecies contact results in disease transmission, 3) infected bighorn sheep return to local population CHHRs, and 4) some disease outbreak may potentially occur. As shown on Map 1 in Appendix C, occupied bighorn sheep habitat in Idaho, Oregon, and Washington occurs in the Salmon River and Snake River drainages of the Columbia River Basin (WAFWA 2010). Idaho bighorn sheep exist in both small isolated populations and interconnected metapopulations (IDFG 2010). Two Rocky Mountain bighorn sheep metapopulations occur within the analysis area; one within the Hells Canyon section of the Snake River and the other within the Salmon River canyon and mountains (see Map 1 in Appendix D). Historically, these populations were likely connected by suitable habitats between the two major drainages and may have functioned as one metapopulation. Today, re-introduced herds of the Hells Canyon population have been established along the Snake River. The indigenous (i.e., not reintroduced) population of the Main Salmon/South Fork local population of Rocky Mountain bighorn sheep occupy the Salmon River, from the Middle Fork Salmon River downstream.

For management purposes, the IDFG has divided bighorn sheep populations and metapopulations into 22 Population Management Units (PMU), including 6 PMUs for California 
bighorn sheep and 16 PMUs for Rocky Mountain bighorn sheep (IDFG 2010). The SEIS analysis area includes the Hells Canyon and Lower Salmon River PMUs for Rocky Mountain bighorn sheep.

\section{Hells Canyon Metapopulation}

The Hells Canyon metapopulation contains 15 local populations, largely defined by reintroduced cohorts (i.e., bighorn sheep groups/herds) that were established in specific areas within Hells Canyon and adjacent areas (see Map 3 in Appendix D). The Hells Canyon bighorn sheep restoration project covers more than 5.6 million acres in the Snake River drainage in Washington, Oregon, and Idaho (HCBSRC 2005). Winter range is limited at the higher elevations of the Wallowa and Seven Devils mountains, but is extensive within the Snake River portion of the project area (HCBSRC 1997). The amount of habitat does not appear to currently limit the number of bighorn sheep since they do not occupy much of the suitable habitat; however, habitat quality such as forage species composition and nutritional value may affect herd size, productivity, and distribution (HCBSRC 1997). The Idaho Bighorn Sheep Management Plan (IDFG 2010) identifies that the current objective for the Hells Canyon PMU is to maintain or increase bighorn sheep populations, which is supported by the objectives and actions identified for bighorn sheep habitat in the Cottonwood RMP (BLM 2009a).

The specific local populations that will be addressed in this document due to proximity to BLM domestic sheep allotments include Upper Hells Canyon, Myers Creek, Muir Creek, Big Canyon, and Sheep Mountain. Population monitoring (e.g., telemetry) of bighorn sheep movements and distribution has revealed overlap and connectivity between herds within the Hells Canyon metapopulation. Telemetry monitoring of collared bighorn sheep has documented varying levels of connectivity between the Upper Hells Canyon, Myers Creek, Muir Creek, and Big Canyon local populations; the current estimated population for these local populations is 110 bighorn sheep (Frances Cassirer, IDFG, personal communication 2013). The Upper Hells Canyon local population includes the combined Upper Hells Canyon Oregon, Upper Hells Canyon Idaho, and Saddle Creek herds. The Sheep Mountain population is more isolated and occurs south of the other four local populations in Hells Canyon discussed above, and has an estimated population of 9 bighorn sheep.

\section{Salmon River Metapopulation}

Native populations of bighorn sheep were never extirpated from the Salmon River canyons and mountains, making them important native genetic stock. Loss of the genetic diversity of these populations could affect bighorn sheep persistence and restoration efforts within central Idaho. The Salmon River metapopulation has several populations distributed along the South Fork Salmon River, Main Salmon River Canyon, and Middle Fork Salmon River. The primary populations that potentially overlap or occur in proximity to BLM domestic sheep allotments include the Main Salmon River and South Fork Salmon River (Main Salmon/South Fork Herd). The Idaho Bighorn Sheep Management Plan (IDFG 2010) identifies that the current objective for the Lower Salmon River PMU is to maintain or increase bighorn sheep populations, which is supported by the objectives and actions identified for bighorn sheep habitat in the Cottonwood RMP (BLM 2009a). 
Over the past 5 years, there have been several observations of bighorn sheep in the Little Salmon River drainage, the origin of which is unknown. This could be a midpoint of a migration, the end point of a foray, or an undocumented population that is resident in the Little Salmon River drainage. The most likely origin of these bighorn sheep is Hells Canyon or Salmon River. Migration corridors to the Little Salmon may include several habitat corridors, such as up from the mouth of the Little Salmon River or down the Rapid River drainage, or they may have resulted from random forays. These observations suggest a degree of habitat site fidelity or preference for this area; however, neither telemetry data nor enough observations exist to determine if an established herd is in this area. The most recent sighting in the Little Salmon drainage is of one bighorn sheep ewe during the spring of 2013. Due to the uncertainty of bighorn sheep status and the documentation of an established local population in the Little Salmon River drainage, the area of incidental sightings that have occurred over the past 5 years will be referred to as an area of concern (i.e., the Little Salmon area of concern) and will be analyzed as a local population. The population size is estimated to be four animals, as this is the number that has been reported in the area within the past 5 years.

The BLM is a partner in the Salmon River Bighorn Sheep Project, an interagency research effort established for the purpose of gaining a better ecological understanding of the Main Salmon/South Fork bighorn sheep local population in the Salmon River canyon. The project area includes a 75-mile portion of the Salmon River drainage in Idaho from the town of Riggins, Idaho, east upriver to the confluence of Big Mallard Creek, and the lower portions of the Little Salmon and South Fork Salmon rivers. The current estimate for the Main Salmon/South Fork local bighorn sheep population is 350 (Frances Cassirer, IDFG, personal communication 2013).

The project participants have been conducting bighorn sheep capture, radio-collaring, and monitoring of movements, distribution, and habitat use since 2008. A total of 68 bighorn sheep ( 28 rams and 40 ewes) have been captured and radio-collared. The actual number of radiocollared sheep will vary during the duration of the study as a result of the capture and radiocollaring of new bighorn sheep, bighorn sheep mortality, and collar malfunction or battery life. As of June 2013, 30 bighorn sheep are being monitored with active radio-collars.

Within the Main Salmon/South Fork herd area bighorn sheep are grouped in a number of different local populations. Distinct ram and ewe social groups occur within the Salmon River Bighorn Sheep Project area. Distribution of social groups, extensive movement rates, and maintenance of large use areas by both rams and ewes result in a high degree of population connectivity within the project area, which could foster the spread of disease within and among social groups; ram groups, although isolated from other ram and ewe groups during most of the year, interacted with multiple ewe groups and members of neighboring ram groups during the rut (Mack 2011). Radio collared rams in the project area were capable of extensive daily movements ( 7 to $15 \mathrm{~km} /$ day) and traveled over large distances ( 11 to $49 \mathrm{~km}$; mean $=33 \mathrm{~km}$ ) between rut and non-rut areas (Mack 2011).

\subsubsection{Historical Context}

Prior to the mid-1800s, bighorn sheep were abundant and widely distributed throughout the western United States. A large proportion of native bighorn south of Canada went extinct beginning in the second half of the nineteenth century (Wehausen et al. 2011). Large declines in 
both bighorn sheep abundance and distribution occurred during the late 1800s and early $1900 \mathrm{~s}$ due to overharvest, habitat loss, and competition for forage and disease transmission from domestic livestock (Goodson 1982; Valdez and Krausman 1999; IDFG 2010). The large region where bighorn sheep extirpations have been so widespread coincides spatially with where domestic sheep have been grazing in North America, and temporally with the beginning of that grazing (Wehausen et al. 2011). Bighorn sheep in North America were estimated to number approximately 1.5 to 2 million (Buechner 1960; Queen et al. 1994). A large decline in the bighorn sheep population in North America, from an estimated 2 million at the beginning of the nineteenth century to fewer than 70,000 in 2009 (Lawrence et al. 2010; Buechner 1960; Valdez and Krausman 1999), has been attributed in part to disease, particularly pneumonia caused by bacteria of the genera Mannheimia, Bibersteinia, and Pasteurella (Coggins 1988; Miller 2001). Recently Mycoplasma ovipneumoniae has been identified in contributing to pneumonia related deaths in eight bighorn sheep populations from 2008-2010 (Besser et al. 2012a).

Archaeological evidence and reports by early explorers indicate that bighorn sheep were widely distributed and abundant in Idaho until the late 1800s (IDFG 2010; Smith 1954; Toweill and Geist 1999), and included both California bighorn sheep (O. c. californiana) in the southwest portion of the state and Rocky Mountain bighorn sheep (O. c. canadensis) northeast of the Snake River Plains. By 1920 the Idaho bighorn sheep population declined to an estimated 1,000 animals (IDFG 2010). In 1969, Idaho began reintroducing Rocky Mountain bighorn sheep into historic habitats. As a result of these efforts, and strict hunting regulations, habitat protection, and translocation of bighorn sheep to historically occupied habitat, the Idaho population increased to approximately 5,000 by 1990 (IDFG 2010). Unfortunately, that number then decreased to 1,710 by 1998 , with population declines attributed to disease outbreaks (Toweill and Geist 1999). More recent statewide estimates for bighorn sheep are 2,900 (IDFG 2010).

More than 10,000 bighorn sheep may have once lived in the Hells Canyon and surrounding mountains, but were extirpated by the mid-1940s by competition for forage with domestic livestock, disease, and unregulated hunting; reintroduction efforts in Hells Canyon began in 1971, and 474 bighorn sheep were transplanted into Hells Canyon between 1971 and 2004 (HCBSRC 2005). In 2005, the Hells Canyon Bighorn Sheep Restoration Committee estimated 875 bighorn sheep were located within Hells Canyon, and the 2011 population estimate is 850 (includes Idaho, Oregon, and Washington). Overall, Hells Canyon modeled habitat could support more bighorn sheep than current population levels. The Hells Canyon PMU (Idaho) predicted bighorn sheep supportable by habitat within the distribution area of bighorn sheep is 1,555 to 2,802 (IDFG 2010). Cassirer and Sinclair (2007) describe the effects of chronic, repeated pneumonia outbreaks on bighorn sheep populations in Hells Canyon and their potential adverse effects on bighorn sheep population recovery and persistence.

The Salmon River metapopulation was never extirpated (Toweill and Geist 1999), although the population has experienced periodic die-offs. No reintroduction or augmentation has occurred in the Lower Salmon River PMU (IDFG 2011). Low recruitment rates and overall declines in sheep numbers over the years for this metapopulation may have been caused by disease and habitat conditions in the Lower Salmon River PMU (IDFG 2010). Population numbers have dwindled in the western portion of this PMU that is closest to active domestic sheep allotments. Disease has resulted in low lamb survival in adjacent herds along the Salmon River, the most significant of which is respiratory disease, which results in negative effects on population dynamics through 
increased adult and lamb mortality (IDFG 2010, 2011). Overall, Lower Salmon River PMU modeled habitat could support more bighorn sheep than current population levels. Salmon River PMU predicted populations supportable by habitat within the distribution area of bighorn sheep is 942 to 1,504 (IDFG 2010). Within the Lower Salmon River PMU, Game Management Unit (GMU) 14 is the most western GMU and occurs the closest to domestic sheep grazing and has low lamb survival. During the period of 2010 to 2012, the lamb to ewe ratio was 9.7 (lambs per 100 ewes) within GMU 14. During the same period, the GMUs within the Lower Salmon River PMU that were farther east and more distant from historic domestic sheep grazing areas ranged from 57 percent to over 200 percent higher for lamb to ewe ratios when compared to GMU 14 ratios.

\subsubsection{Disease Transmission}

Disease was a significant factor in the historic decline of bighorn sheep and is a key factor limiting recovery (Besser et al. 2012a; WAFWA 2012; Wehausen et al. 2011; Lawrence et al. 2010; IDFG 2010). Free-ranging bighorn sheep are susceptible to many diseases, but pneumonia has the greatest impact on populations (Singer et al. 2000; Monello et al. 2001). Bighorn sheep are vulnerable to organisms carried by healthy domestic sheep and goats, and there is no effective treatment once these organisms are transmitted (IDFG 2010). The most important of these diseases is bronchopneumonia, which is usually associated with bacteria in the genera Pasteurella and Mannheimia (Bunch et al. 1999; Miller 2001). Pneumonia caused by these bacteria has produced partial to complete die-offs of herds across the species' range, with the frequency of die-offs being particularly high in the northwestern United States (Monello et al. 2001). The current abundance and distribution of the species appears to be largely limited by recurrent pasteurellosis epidemics (Hobbs and Miller 1992; Jorgenson et al. 1997; McCarty and Miller 1998).

A history of large-scale, rapid, all-age die-offs in bighorn sheep has been documented across Canada and the United States, many presumed to be associated with domestic animal contact (Shackleton 1999). Although there is limited knowledge of transmission dynamics (Garde et al. 2005), extensive scientific research supports a relationship between disease in bighorn sheep populations and contact with domestic sheep. The literature includes circumstantial evidence linking bighorn die-offs in the wild to contact with domestic animals, as well as controlled experiments where healthy bighorn sheep exposed to domestic sheep displayed subsequently high mortality rates (Wehausen et al. 2011; Lawrence 2010; Foreyt 1989, 1990, 1992a, b; Foreyt et al. 1994; Onderka et al. 1988; Onderka and Wishart 1988; Garde et al. 2005). Pneumonia in bighorn sheep populations usually results in an initial all-age die-off, continued chronic low level of adult mortality, and annual or sporadic high rates of mortality of lambs (generally from 1-3 months of age). Increased mortality rates of lambs may continue for one to $>20$ years (Rush 1927, Jorgenson et al. 1997, Aune et al. 1998, Enk et al. 2001, Hnilicka et al, 2002, and Cassirer et al. 2013). While much of the evidence for disease transmission from domestic sheep to freeranging bighorn sheep is circumstantial, a large literature base has emerged that documents bighorn sheep die-offs near domestic sheep. These die-offs have prompted management decisions to eliminate shared use of ranges by bighorn and domestic sheep by federal land management agencies and state wildlife departments (Goodson 1982). Transmission of 
Mannheimia haemolytica from domestic sheep to bighorn sheep was irrefutably demonstrated by Lawrence et al. (2010) (WAFWA 2012).

Bighorn sheep commonly occur in spatially structured, demographically independent, interconnected populations in steep, rugged terrain (Cassirer et al. 2013), which is typical of the Hells Canyon and Salmon River metapopulations. Males and females pursue different lifehistory strategies (Bleich et al. 1996; Rubin et al. 2002) and interactions between the sexes are concentrated around the breeding season which is relatively short in northern latitudes and high altitudes (Bunnell 1982; Thompson and Turner 1982; Bleich et al. 1997; Valdez and Krausman 1999). Outside the breeding season, mature males and females generally occur in male-only, female-only, or female-offspring associations (Cassirer et al. 2013). Males are more mobile and more likely than females to contact conspecific hosts in adjacent populations, or potential disease reservoirs such as domestic sheep (Bleich et al. 1997; Rubin et al. 1998; DeCesare and Pletscher 2006). Initially, infection probably originates in domestic sheep, but once the disease has spread into bighorn sheep population it is most likely maintained in the population and spread by bighorn sheep (Cassirer et al. 2013). Consequently, once disease transmission has occurred between domestic sheep/goats and bighorn sheep, the interconnected populations within Hells Canyon and Salmon River metapopulations are at continued risk from spread of disease by infected bighorn sheep contacting other bighorn sheep. See Appendix A for a more detailed discussion and review of the research regarding bighorn sheep disease and transmission.

\section{Disease History of Hells Canyon Metapopulation}

Bighorn sheep were extirpated from Hells Canyon and the surrounding area by 1945 (Smith 1954; Johnson 1980; ODFW 1992). From 1971 to 2002, 492 additional bighorn sheep from 11 source populations (not from Hells Canyon population), and 124 bighorn sheep (from within the Hells Canyon population) were relocated within the Hells Canyon area. At least six pneumonia epizootics (population die-offs) occurred between 1972 and 1996 within the Hells Canyon metapopulation (HCBSRC 2004). In 2012, a population all-age die-off occurred in the northern most population of the Hells Canyon population in Washington state (Francis Cassirer, 2013, personal communication). Pasteurella multocida was associated with a major die-off in Hells Canyon in 1995-1996 (Frank et al. 2004). During this time, more than 300 bighorn sheep died of pneumonia in Hells Canyon, possibly caused by contact with one goat (Cassirer et al. 1996; Coggins 2002). During this period, bighorn sheep on the Idaho side of the river showed signs of respiratory disease, but no die-off was documented (Cassirer et al. 1996). Five die-offs within the Hells Canyon metapopulation have been circumstantially linked to domestic sheep (Coggins 1988). Cassirer and Sinclair (2007) describe the effects of chronic, repeated pneumonia outbreaks on bighorn sheep populations in Hells Canyon, and their potential adverse effects on bighorn sheep population recovery and persistence. Cassirer and others identified that in some cases, even in the absence of a large-scale die-off, chronic or sporadic pneumonia-caused mortality can be the primary factor limiting population growth, especially in juvenile age classes (Cassirer et al. 2013).

Six bighorn sheep local populations of the Hells Canyon metapopulation occur within 30 air miles from BLM domestic sheep allotments, including: Upper Hells Canyon, Myers, Muir Creek, McGraw, Big Canyon, and Sheep Mountain. The other populations have had periodic pneumonia outbreaks that have resulted in substantial mortality, as indicated by bighorn sheep 
downward population trends in Hells Canyon (Figure 3-1). Disease has reduced the population growth rate of the Hells Canyon metapopulation by at least 40 percent (HCBSRC 1997).
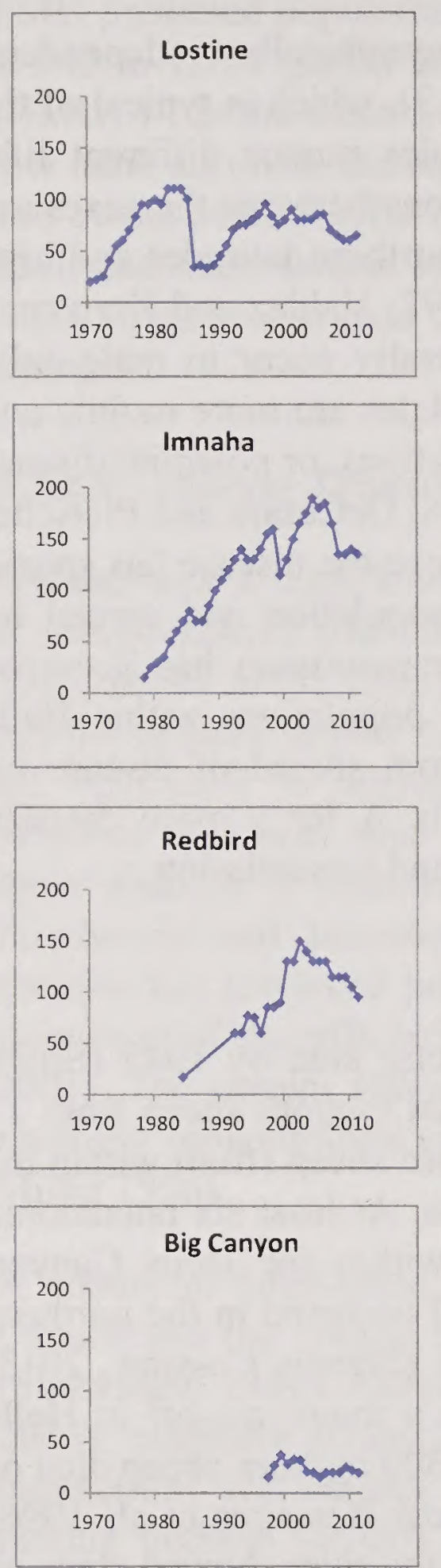
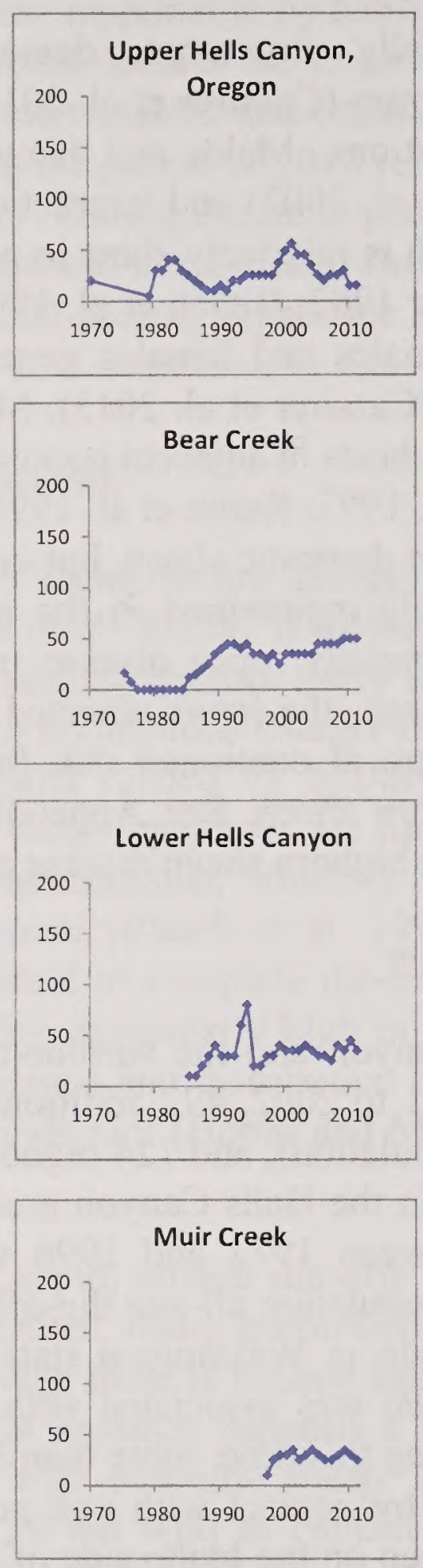
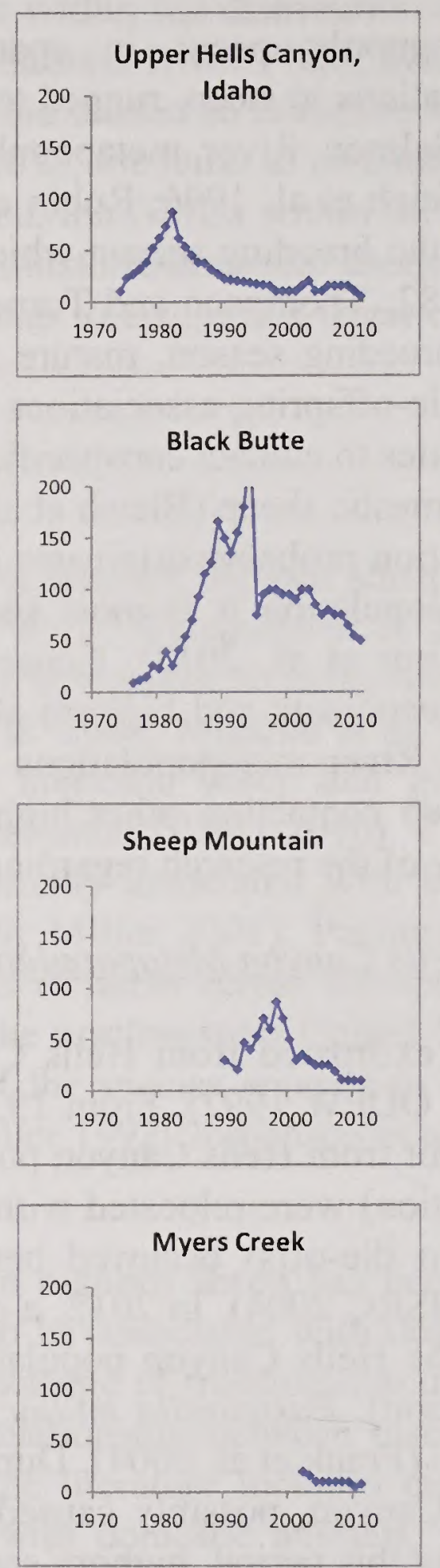
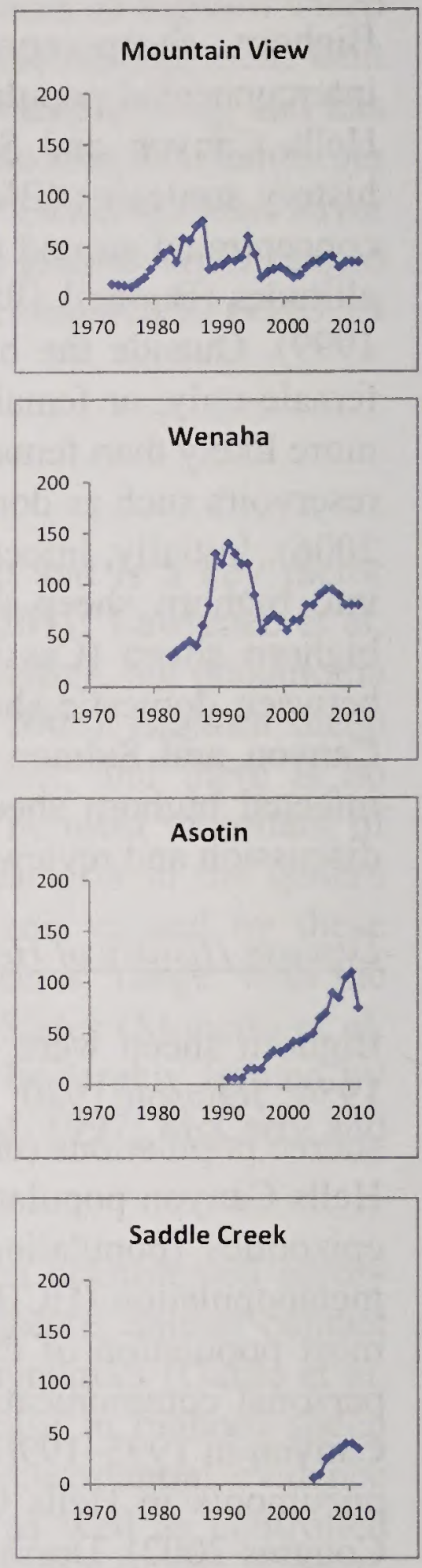

Figure 3-1: $\quad$ Population Trends for Bighorn Sheep by Herd in Hells Canyon (Source: WDFW, ODFW, and IDFG bighorn sheep population census data)

\section{Disease History of Salmon River Metapopulation}

For the Salmon River metapopulation, the IDFG collects census data by game management unit (GMU) (see Map 3 in Appendix D). As shown in Figure 3-2, the census data collected by the IDFG suggests significant bighorn sheep declines in several of these GMUs. Helicopter surveys during 2010, 2011, and 2012 were conducted specifically for bighorn sheep, while earlier surveys for bighorn sheep were incidental sightings during surveys for elk (IDFG 2010). Consequently, population numbers and upward trends cannot be concluded from the higher population counts (e.g., GMU 19) when compared to earlier survey years. 

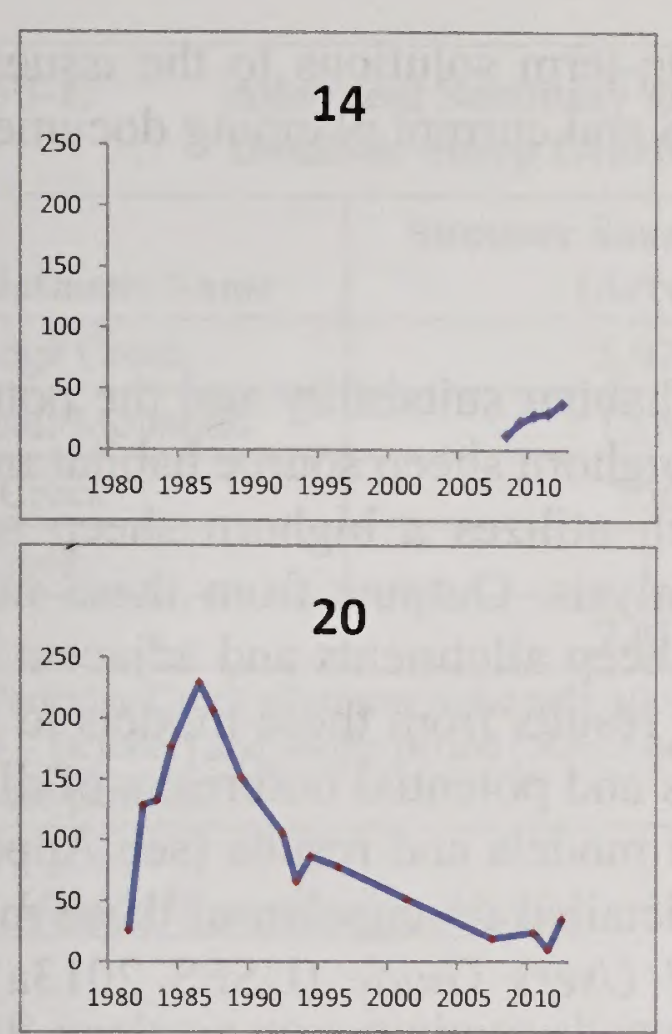
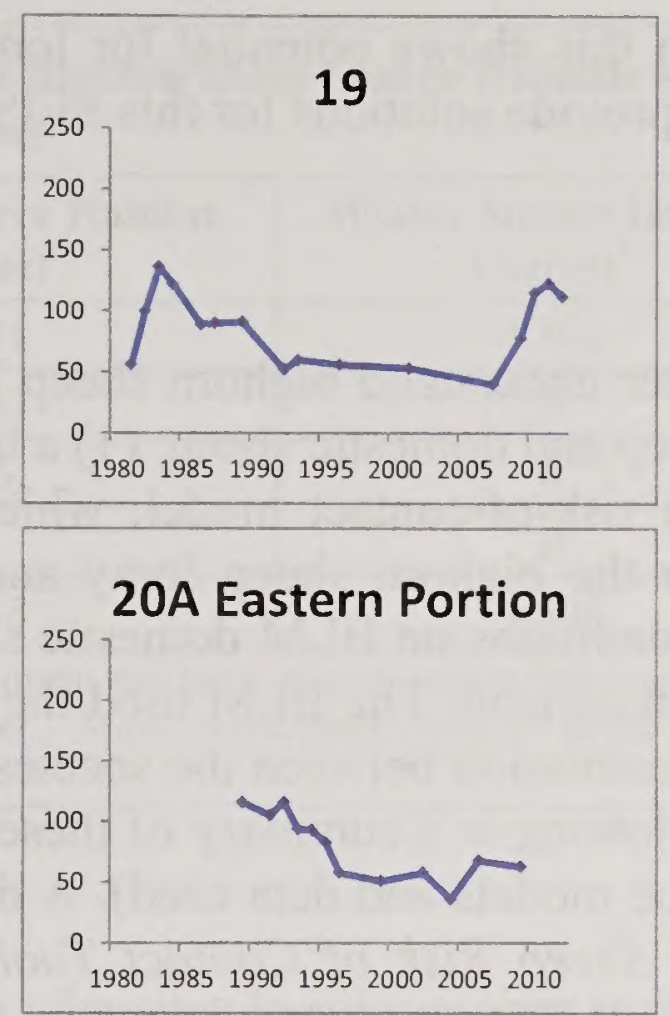
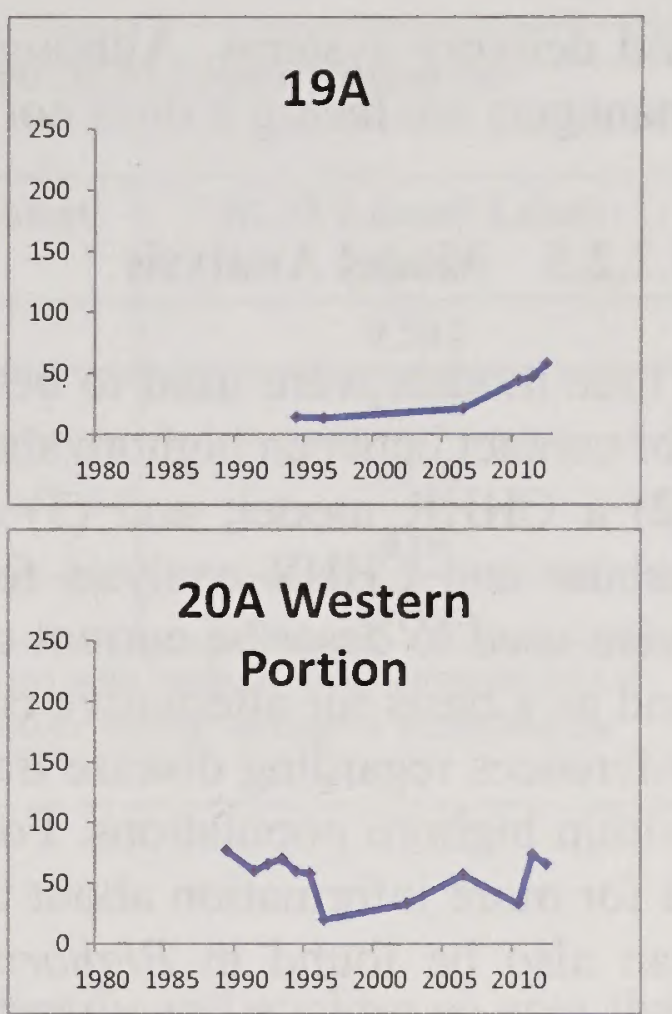

Figure 3-2: $\quad$ Population Trends for Bighorn Sheep in Idaho Big Game Management Units that Overlap the Main Salmon/South Local Population Analysis Area (Source: IDFG bighorn sheep population census data)

The Main Salmon/South Fork population occurs within the Lower Salmon River PMU. Evidence suggests that disease has had severe implications on this population, which occurs within the Salmon River metapopulation (IDFG 2004a, 2006, 2010). The IDFG (2010) identified that low recruitment rates and overall declines in bighorn sheep have occurred in the Lower Salmon River PMU and specific GMUs and may have been caused by disease and habitat conditions. IDFG (2010) also identified that population numbers have dwindled in the western portion of the Lower Salmon PMU (GMU 14), which is closest to active domestic sheep allotments, and disease has resulted in low lamb survival in adjacent herds along the Salmon River.

From 1987 to 1991, a population on Big Creek within GMU 27 experienced 5 years of low lambto-ewe ratios and an all-age die-off in 1990 (Akenson and Akenson 1992). Research conducted in April 2000 found a highly virulent strain of Pasteurella spp. in the Big Creek population (IDFG 2004a, 2006).

\subsubsection{Vaccines and Range Applications}

There are a number of pathogens that have been implicated in bighorn sheep that cause pneumonia and death that are common to domestic sheep and cause none or little symptoms in domestic sheep or goats. Two of the most lethal pathogens (Mannheimia haemolytica, leukotixin positive) and Mycoplasma ovipneumoniae) to bighorn sheep have been studied by researchers at Washington State University. Both researchers have indicated that development of specific vaccines to each of these bacteria may take 5 to 10 years for development. In addition to development of these vaccines, development of delivery systems to wild sheep are problematic and to date have not proved effective for wildlife with other diseases. A recent publication by Besser et al. (2013) and correspondence by Dr. Subramaniam Srikumaran, Washington State University, to the Payette National Forest Supervisor in 2010 discusses issues with both vaccines 
and delivery systems. Although this shows potential for long-term solutions to the issues that managers are facing it does not provide solutions for this SEIS and current planning document.

\subsubsection{Model Analysis}

Three models were used to better understand bighorn sheep habitat suitability and the potential for contact between bighorn sheep and domestic sheep: (1) a bighorn sheep source habitat model; (2) a CHHR model; and (3) a risk-of-contact model, which utilizes a bighorn sheep source habitat and CHHR analysis for the bighorn sheep foray analysis. Outputs from these models were used to describe current conditions on BLM domestic sheep allotments and adjacent areas and as a basis for alternative comparison. The BLM used the results from these models to make inferences regarding disease transmission between the species and potential outbreaks of disease within bighorn populations. Following is a summary of these models and results (see Appendix B for more information about the models and data used). A detailed description of these models can also be found in Bighorn Sheep Risk of Contact Tool Users Guide (USFS 2013a) and Appendix L of the Payette FSEIS (USFS 2010a).

\section{Source Habitat Model}

Source habitats are those characteristics of macrovegetation that contribute to positive population growth for a species in a specified area and time; they contribute to source environments, which represent the composite of all environmental conditions that result in stationary or positive population growth in a specified area and within a specified time (Wisdom et al. 2000; Raphael et al. 2001). Source habitats have been described for bighorn sheep in alpine, subalpine, upland shrubland, and upland herbland community groups; alpine and subalpine community groups are primarily summer range, while upland herbland and shrubland are used in both seasons, depending on elevation (Wisdom et al. 2000).

Within the four BLM domestic sheep allotments, 7,015 acres of summer source habitat and 4,502 acres of winter source habitat exist, representing 36 percent (summer source habitat) and 23 percent (winter source habitat) of the total acreage within BLM domestic sheep allotments. Source habitat for bighorn sheep is distributed within the Salmon and Snake River canyon lands and adjacent landscape, which includes the BLM domestic sheep allotments (see maps 6 and 7 in Appendix D). Allotment-specific bighorn sheep source habitat and BLM land leased for domestic sheep grazing are summarized in Table 3-1. 
Table 3-1: $\quad$ Allotment Summary of Bighorn Sheep Source Habitats and BLM Lands Leased for Domestic Sheep Grazing

\begin{tabular}{|l|c|c|c|}
\hline \multicolumn{1}{|c|}{ Allotment Name } & $\begin{array}{c}\text { Summer Source Habitat } \\
\text { (Acres) }\end{array}$ & $\begin{array}{c}\text { Winter Source Habitat } \\
\text { (Acres) }\end{array}$ & $\begin{array}{c}\text { BLM Leased Lands } \\
\text { (Acres) }\end{array}$ \\
\hline Partridge Creek & 5,071 & 4,502 & 9,544 \\
\hline Marshall Mountain & 1,187 & 0 & 4,212 \\
\hline Hard Creek & 756 & 0 & 5,210 \\
\hline Big Creek & 1 & 0 & 439 \\
\hline Total & $\mathbf{7 , 0 1 5}$ & $\mathbf{4 , 5 0 2}$ & $\mathbf{1 9 , 4 0 5}$ \\
\hline
\end{tabular}

'The Partridge Creek allotment is the only allotment that has a grazing season that overlaps with bighorn sheep summer period (May - Oetober) and winter period (November - April), consequently bighorn sheep souree habitat aereage is identified for both use periods.

\section{Core Herd Home Range Model}

CHHR analysis uses bighorn sheep telemetry location points to identify and enclose an area that contains 95 percent of all telemetry points from radio-collared bighorn sheep. This process was carried out for each identifiable individual within a herd for whom more than 20 telemetry points were available. All other telemetry and observation points for herds that did not meet these criteria were excluded from the CHHR analysis, but were used to verify the accuracy of the final CHHR volume contours.

Analysis was conducted for summer and winter CHHRs. Bighorn sheep telemetry locations occurring May through October are used for determining summer CHHR, and bighorn sheep telemetry locations occurring November through April are used for modeling winter CHHR.

\section{Risk of Contact Model}

For analysis of the risk of contact, the BLM used a model that estimates the probability that foraying bighorn sheep will reach a domestic sheep allotment. However, within an allotment it is not possible to determine where and when domestic sheep would consistently occur or for how long. Use of some areas within an allotment may present less chance of contact with bighorn sheep than others, while some areas may have higher probability of occurrence (e.g., source habitats). Consequently, because of this uncertainty the only feasible and suitable method to predict potential interspecies contact was to use the Risk of Contact Model and use the assumption that contact with an allotment results in interspecies contact. By definition, where a CHHR overlaps an allotment, there is contact with the allotment and the assumption is that one or more contacts per year may occur. It is acknowledged that stray domestic sheep have been implicated in several die-offs for bighorn sheep, and in many rangeland settings may pose a risk of disease transmission as large as or greater than from foraying bighorn sheep. However, the bighorn sheep risk of contact tool (USFS 2013) does not model the risk of stray domestic sheep and the subsequent potential for contact with bighorn sheep. Since there is currently no domestic sheep grazing on BLM allotments in the analysis area, there is no risk of contact with bighorn sheep within these allotments or from straying domestic sheep or foraying bighorn sheep. This model was used to determine the effects of alternatives as described in Chapter 4. 
The contact model is based on an analysis of 16 years of bighorn sheep telemetry data from the Hells Canyon populations (see Appendix B); its construction involves two distinct analyses. First, the analysis is used to delineate areas where most animals in each herd spend at least 95 percent of their time (the CHHR); telemetry data from Hells Canyon and Salmon River bighorn sheep was used for this analysis. Next, the analysis examines the characteristics of bighorn sheep movements, or forays, outside of the CHHR. This foray analysis examines how frequently and at what season foray movements occur, as well as how far beyond the CHHR animals are likely to travel. Together, the habitat, CHHR, and foray models are used to estimate the probability that a ewe or a ram in any of the herds will reach any of the open allotments in a given year.

Modeling the CHHR provided information to analyze the impacts of domestic sheep grazing on BLM domestic sheep allotments and on the landscape level for bighorn sheep metapopulations. The analysis also highlighted the extent of the overlap and possible interaction among the different herds throughout the Hells Canyon and Salmon River metapopulations. The first step in developing the CHHR model was to calculate separately the home range of each individual animal. Occasional movement outside of the area could be exploratory in nature and was not considered part of the CHHR. These excursions, or forays, were of great interest to the modelers and were analyzed separately in the foray model.

The tools and processes used to complete CHHR analysis are common to home range analyses used for many other species. This analysis used observations and telemetry data collected by the Hells Canyon Initiative from 1997 to 2011. The data was then used to divide the bighorn sheep populations into herds. Although the Hells Canyon metapopulation is comprised of numerous herds, this analysis focuses on the following herd assignments that were based on transplant cohorts to specific locations and breeding groups of ewes that shared the same range: Upper Hells Canyon, Muir Creek, Myers Creeks, Big Canyon, and Sheep Mountain. The bighorn sheep in the Salmon River metapopulation are endemic rather than reintroduced, so herds divisions were defined differently. Named herds in the Salmon River were based on the type of observations available for describing their locations: the Main Salmon/South Fork included animals radio-collared as a part of the Salmon River study in 2007-2012 (ongoing); the Big Creek population included animals radio-collared by Akenson and Akenson (1992) in 1989 and 1990, and the Upper Salmon; and the Upper Main Salmon was comprised of animals in the Salmon River Canyon between the Upper Main Salmon/South Fork and Big Creek populations, for which no telemetry data were available. The allotment-specific CHHR acreage and distance from each herd CHHR is summarized in Table 3-2 and Table 3-3 
Table 3-2: $\quad$ Summer and Winter Core Herd Home Ranges and Domestic Sheep Allotments

\begin{tabular}{|c|c|c|c|c|c|}
\hline $\begin{array}{c}\text { Core Herd Home } \\
\text { Range Information }\end{array}$ & $\begin{array}{c}\text { Partridge Creek } \\
\text { Allotment }\end{array}$ & $\begin{array}{c}\text { Marshall Mountain } \\
\text { Allotment }\end{array}$ & $\begin{array}{c}\text { Hard Creek } \\
\text { Allotment }\end{array}$ & $\begin{array}{l}\text { Big Creek } \\
\text { Allotment }\end{array}$ & Total Acres \\
\hline CHHR Acres $^{1,2}$ & $\begin{array}{r}5,376 \mathrm{~S} \\
8,008 \mathrm{~W}\end{array}$ & 0 & $2,629 \mathrm{~S}$ & 0 & $\begin{array}{r}8,005 \mathrm{~S} \\
8,008 \mathrm{~W}\end{array}$ \\
\hline $\begin{array}{l}\text { Distance to Nearest } \\
\text { CHHR (Miles) }{ }^{1,2}\end{array}$ & $0.0 \mathrm{~S} \& \mathrm{~W}$ & $1.19 \mathrm{~S}$ & $0.0^{2} \mathrm{~S}$ & $12.96 \mathrm{~S}$ & --- \\
\hline $\begin{array}{l}\text { BLM Lands Leased } \\
\text { for Domestic Sheep } \\
\text { Grazing (Acres) }\end{array}$ & 9,544 & 4,212 & 5,210 & 439 & 19,405 \\
\hline \multicolumn{6}{|c|}{$\begin{array}{l}{ }^{\text {I }} \text { = Summer CHHR and } \mathrm{W}=\text { Winter CHHR. The Partridge Creek Allotment is the only allotment that has a grazing season } \\
\text { that overlaps with bighorn sheep summer period (May-Oetober) and winter period (November-April), consequently bighorn } \\
\text { sheep CHHR acreage are identified for both use periods. } \\
{ }^{2} \text { The Partridge Creek Allotment has overlap with summer and winter CHHR for the Main Salmon/South Fork local population } \\
\text { and the Hard Creek Allotment has overlap with Little Salmon area of concern. }\end{array}$} \\
\hline
\end{tabular}

Table 3-3: $\quad$ Allotment Distances (Miles) from Core Herd Home Ranges'

\begin{tabular}{|c|c|c|c|c|}
\hline Herd Name & $\begin{array}{c}\text { Partridge Creek } \\
\text { Allotment }\end{array}$ & $\begin{array}{c}\text { Marshall Mountain } \\
\text { Allotment }\end{array}$ & $\begin{array}{c}\text { Hard Creek } \\
\text { Allotment }\end{array}$ & $\begin{array}{l}\text { Big Creek } \\
\text { Allotment }\end{array}$ \\
\hline Main Salmon/South Fork & $\begin{array}{l}0.0 \mathrm{~S} \\
0.0 \mathrm{~W}\end{array}$ & $1.19 \mathrm{~S}$ & $12.15 \mathrm{~S}$ & $31.98 \mathrm{~S}$ \\
\hline Little Salmon $^{2}$ & $3.53 \mathrm{~S} \& \mathrm{~W}$ & $18.30 \mathrm{~S}$ & $0.0 \mathrm{~S}$ & $12.96 \mathrm{~S}$ \\
\hline Upper Hells Canyon & $\begin{array}{c}15.35 \mathrm{~S} \\
16.60 \mathrm{~W} \\
\end{array}$ & $29.73 \mathrm{~S}$ & $10.23 \mathrm{~S}$ & $26.14 \mathrm{~S}$ \\
\hline Myers & $\begin{array}{c}5.96 \mathrm{~S} \\
13.21 \mathrm{~W}\end{array}$ & $20.84 \mathrm{~S}$ & $11.28 \mathrm{~S}$ & $33.83 \mathrm{~S}$ \\
\hline Muir & $\begin{array}{l}15.72 \mathrm{~S} \\
14.44 \mathrm{~W}\end{array}$ & $27.72 \mathrm{~S}$ & $21.26 \mathrm{~S}$ & $44.23 \mathrm{~S}$ \\
\hline Big Canyon & $\begin{array}{c}17.44 \mathrm{~S} \\
17.15 \mathrm{~W}\end{array}$ & $29.10 \mathrm{~S}$ & $19.14 \mathrm{~S}$ & $41.84 \mathrm{~S}$ \\
\hline Sheep Mountain & $\begin{array}{l}44.96 \mathrm{~S} \\
46.02 \mathrm{~W}\end{array}$ & $29.10 \mathrm{~S}$ & $30.62 \mathrm{~S}$ & $30.35 \mathrm{~S}$ \\
\hline \multicolumn{5}{|c|}{$\begin{array}{l}\text { 'S = Summer CHHR and } \mathrm{W}=\text { Winter CHHR. The Partridge Creek Allotment is the only allotment that has a grazing season } \\
\text { that overlaps with bighorn sheep summer period (May October) and winter period (November-April), consequently bighorn } \\
\text { sheep CHHR distances are identified for both use periods. }\end{array}$} \\
\hline
\end{tabular}

Similar to bighorn sheep elsewhere, Hells Canyon and Salmon River bighorn sheep, particularly rams, make occasional long-distance movements beyond their CHHR. Singer et al. (2001) defined these forays as any short-term movement of an animal away from and back to its CHHR. This life-history trait can put bighorn sheep at risk of contact with domestic sheep, particularly when suitable habitats are well connected and overlap with domestic sheep use areas (Singer et al. 2000c; Gross et al. 2000), or even when domestic sheep use is outside of CHHR areas. The risk of contact between dispersing bighorn sheep and domestic sheep is related to the number of bighorn sheep in a herd, proximity of domestic sheep use areas (allotments) to a bighorn sheep CHHR, distribution of bighorn sheep source habitats across the landscape, and frequency and distance of bighorn sheep forays outside of the CHHR. 
The sequence of events by which a disease outbreak could result from contact between a bighorn sheep and a domestic sheep or goats in an active allotment located outside of bighorn sheep CHHR can be broken down into a number of steps. To reach an occupied allotment, a bighorn sheep must (1) leave the CHHR; (2) travel far enough to reach the allotment; then (3) intersect the allotment (i.e., rather than some other area at the same distance from the CHHR). Once this occurs, in order for disease transmission to occur, the bighorn sheep must (4) come into contact with domestic sheep in the allotment and (5) contract the disease from the domestic sheep. For an outbreak to affect the animal's home herd, the infected bighorn sheep must (6) make its way back to the CHHR and (7) transmit the disease to other members of the herd. Uncertainty is identified within the literature regarding what levels of interspecies contacts in a rangeland situation result in disease transmission and disease outbreaks within a bighorn sheep population. Because of this uncertainty, the BLM did not conduct herd specific modeling in regard to disease transmission and herd persistence.

The contact model described in this section aims to determine the probability that a bighorn sheep will reach an occupied allotment.

\section{Interpreting Contact Rates Relative to Disease Outbreaks and Bighorn Sheep Population}

\section{Persistence and Analysis Assumptions}

A high degree of uncertainty exists regarding the probability that contact of a bighorn sheep with an allotment will lead to disease outbreak occurring within a herd (USFS 2010a, USFS 2013b; Carpenter et al. 2014; O'Brien et al. In press). Quantification of disease transmission and outbreaks in bighorn sheep populations following contact with domestic sheep or goats, and the subsequent ability of a population to recover, are key to interpreting the results from the above models; however, the mechanisms of disease transmission and resulting disease outbreaks in bighorn sheep is not fully understood. We currently lack empirical data to make recommendations as to the frequency of outbreaks and the effects on population persistence. Therefore, the BLM relied on the following assumptions to assist with the interpretation:

- If a bighorn population suffers a disease outbreak more frequently than once every 50 years, the population will not fully recover, which may lead to extirpation. The effects of respiratory disease outbreaks on bighorn sheep populations are often severe (Besser et al. 2012a, b). Controlled pen experiments identified in Besser et al. 2012a resulted in complete or nearly complete die-offs of bighorn sheep following contact with domestic sheep. It has also been documented that disease perturbations can affect lamb recruitment for several years following a severe population decline resulting from a disease outbreak that rapidly affects many animals in a specific area at the same time (Besser et al. 2012b; Coggins and Matthews 1992; Foreyt 1990). Consequently, when bighorn sheep disease die-offs occur, there is a substantial immediate mortality (population decline) and a delayed recovery due to poor lamb recruitment that can follow the disease outbreak for many years (Besser et al. 2013). Population recovery is unlikely where interspecies contact, potentially resulting in disease transmission and subsequent disease outbreak, occurs within a few decades of each other (Cassirer et al. 2013). There is no specific guidance on the number of decades required to recover from a disease outbreak; observations of herds that have experienced pneumonic events indicate it likely requires several. 
Another important trend of wild-domestic sheep disease transmission is that an illness's effect on individual bighorn populations can be long-lasting. For example, in the 1980s in California's Santa Rosa Mountains, lambs regularly died from pneumonia (DeForge et al. 1997; DeForge et al. 1982). According to DeForge and others (1997): "[In the] Santa Rosa Mountains... a disease outbreak reportedly struck bighorn in the late 1970s. This epizootic contributed to at least 13 years of poor recruitment and an 81 percent population decline in the... adult bighorn population between 1979 and 1996." Cahn and otherś (2011) explained the trend of suppressed lamb recruitment: "Whether mild or severe, most respiratory disease outbreaks in bighorn populations are followed by several years of pneumonia caused mortality of lambs resulting in low recruitment rates and juvenile survival. Continuing lamb infection apparently results from females that remain infective following an outbreak, although mortality or morbidity among the females may not be detectable. Such recurring lamb infections can substantially delay the recovery of depleted populations to pre-outbreak levels."

- The BLM recognizes the uncertainty regarding the relationship between the number of bighorn sheep contacts with a domestic sheep allotment and predictions for disease transmission and outbreaks, but for this analysis the BLM assumed that the probability that contact with domestic sheep or goats will result in disease outbreak in a bighorn population to be 1 in 4 (or 25 percent). Due to the uncertainty in the amount of contacts between domestic sheep and bighorn sheep needed to result in disease transmission to bighorn sheep, the USFS in their Payette FSEIS (USFS 2010a) analyzed a range of probabilities of contacts needed to allow for disease transmission. These ranged from one contact equals disease transmission to 20 contacts are needed for disease transmission. Similar to the Payette FSEIS, and uncertainty regarding number of contacts and disease transmission the BLM also analyzed a range of probabilities of contacts which resulted in disease transmission, but used the 1 in $4(0.25)$ as a moderate probability for analyzing and comparing the effects of alternatives.

Applying these assumptions to the results from the models indicates that it is highly likely that a herd will not fully recover and will have moderate or high risks for extirpation if the probability of contact is equal to or exceeds 0.08 contact per year (one contact every 12.5 years), and using the above probability that 1 in 4 contacts would result in disease outbreak, which translates into a disease outbreak every 50 years (USFS 2013b).

It is important to disclose that accurate individual-level modeling of the impacts of disease events is difficult, as the dynamics of respiratory disease in the wild are only partly known. An individual-based model would require understanding many factors, such as the incubation period and active infection durations, the probability and rate of recovery from disease, the rate of effective contact between individuals within the herd, and the possible role of persistently infected individuals in harboring and spreading the disease. Variations in the resistance to disease of individual bighorn sheep and in the virulence of the disease-causing organisms themselves can also affect population dynamics.

Furthermore, modeling population dynamics of large herbivores at the individual level requires estimating numerous parameters, from adult and juvenile survival rates to age at sexual maturity, fecundity, and lamb survival (Gaillard et al. 2000). In addition, the average values for each of 
those life-history parameters may be modified by interacting impacts of density dependence, weather, forage availability, and predation. Properly estimating these parameters would require extensive age- and class-specific population data, ideally from the populations being modeled. Such data is not currently available.

\subsubsection{Risk of Interspecies Contact and Straying of Domestic Sheep from Grazing Allotments and While Trailing}

The analysis in this SEIS focused on interspecies contact resulting from foraying bighorn sheep intersecting with a domestic sheep allotment. However, another concern is the straying of domestic sheep from sheep bands on grazing allotments, or while trailing, and the potential contact with bighorn sheep (WAFWA 2010, 2012; USFS 2010a; Cahn et al. 2011).

A principal assumption from the published literature is that direct contact between domestic sheep and bighorn sheep results in a high likelihood of disease transmission to bighorn sheep and disease outbreaks in local bighorn sheep herds (Wehausen et al. 2011; WAFWA 2012). Risk factors include (1) distance between domestic sheep allotments and the nearest bighorn sheep populations; (2) amount and distribution of bighorn sheep habitat within and between domestic sheep allotments; (3) stray domestic sheep and forays of bighorn sheep, particularly males during the rut; and (4) seasonal bighorn sheep distribution and movement near the allotments when grazed by domestic sheep.

The potential for straying by domestic sheep is dependent on a variety of factors, including: dense vegetation and rugged terrain, which reduces the ability of sheepherders to observe or locate domestic sheep; experience and responsibility of sheepherders; maturity and effectiveness of herd/guard dogs; number of herders and herd/guard dogs; occurrence of sick or physically disabled domestic sheep in the band; lagging domestic sheep while trailing; adequacy of stray or loss domestic sheep monitoring or detection; and lack of a response plan regarding comprehensive search and stray sheep locating. In addition, the scattering and straying of domestic sheep may occur from predator disturbance or other human or natural conditions.

Coggins (2002) identified a stray domestic ewe that traveled at least 30 miles from private land to bighorn sheep range through rugged terrain and heavy timber, and across at least one river (Coggins 2002). These stray domestic sheep will continue to graze the same area or continue to wander, which would reduce the effectiveness of separation buffers that may be in place to reduce the risk of contact with bighorn sheep, increasing the risk of contact with bighorn sheep. This risk of contact is further dependent on proximity of occupied bighorn sheep habitats. Stray domestic sheep may utilize bighorn sheep habitats outside of the grazing season. Consequently, if stray domestic sheep utilize CHHR areas and other summer/winter source habitats, domestic sheep may come into contact with bighorn sheep for long periods of time, increasing the probability for disease transmission and risk of bighorn sheep disease outbreak.

Bighorn sheep and domestic sheep have a gregarious behavior which increases the potential for interspecies contact and disease transmission. This gregarious behavior may be exacerbated during the rut or breeding period for the two species. During the rut (breeding period), male bighorn sheep are more active and rutting foray distances often increase with males in search of female bighorn sheep in estrus. In addition, grazing estrous domestic female sheep heightens the 
attraction and probability of association between bighorn sheep and domestic sheep (WAFWA 2012).

\subsubsection{Predation and other Factors}

Additional stressors to bighorn sheep include overcrowding on limited range, loss of escape cover, harassment by dogs, encroachment by humans, heavy snowfall and other weather stressors (Bunch et al. 1999), parasitism, poor nutrition, predation, and other human disturbances such as roads, habitat degradation, noise, genetics, high population densities, capture and restraint techniques, breeding behavior, the presence of other wildlife, and high dust levels (Festa-Bianchet 1988; Jenkins et al. 2000; Jones and Worley 1994; Foreyt 1998; Monello et al. 2001). These stressors may reduce the ability of bighorn sheep to resist disease (Garde et al. 2005). (See Appendix A for a review of research regarding these factors.)

Bighorn sheep have evolved with a variety of predators (Sawyer and Lindzey 2002; IDFG 2010), including mountain lions (Puma concolor), gray wolves (Canis lupus), coyotes (Canis latrans), bobcats (Lynx rufus), lynx (Lynx lynx), black bears (Ursus americanus), grizzly bears (Ursus arctos horribilis), wolverines (Gulo gulo), and golden eagles (Aquila chrysaetos). Disease transmission, human disturbance, overgrazing, and habitat loss are often cited as factors responsible for declines in bighorn sheep abundance and distribution, while predation is rarely considered a significant mortality factor (Wishart 1975, 1978).

Much of the literature suggests that efficient anti-predator strategies of bighorn sheep greatly reduce their vulnerability to predation (Buechner 1960; Hornocker 1970; Geist 1971; Jorgenson et al. 1997; Wishart 2000). Bighorn sheep gregariousness and the use of steep, rugged terrain appear to be effective adaptations to avoid predation by coursing predators such as wolves and coyotes (Wishart 2000). Stalking predators such as cougars, however, may be able to circumvent these strategies, and predation losses in some herds may be high if individual cougars specialize in preying upon bighorn sheep (Ross et al. 1997). Most accounts of bighorn sheep predation involve cougars or coyotes (Sawyer and Lindzey 2002). Coyote predation appears to be incidental, primarily restricted to lambs, and most often reported in areas that lack suitable escape terrain; and cougars appear to be the only predators capable of causing significant mortality in bighorn sheep.

Wolves occasionally prey upon Dall sheep (Holleman and Stephenson 1981; Heimer and Stephenson 1982; Gasaway et al. 1983; Huggard 1993; Nichols and Bunnell 1999), but have not been reported as a significant source of mortality in bighorn sheep populations. Wolf predation has not been documented to cause population-level impacts on bighorn sheep (IDFG 2010). In Yellowstone National Park, wolves did not prevent the bighorn sheep population from increasing (7 percent annual increase from 1998 to 2005) during the decade after wolf reintroduction, when wolf numbers increased from 21 to a maximum of 106 (White et al. 2008). In the Salmon River Mountains of central Idaho, Husseman and others (2003) documented 120 wolf-killed and 98 mountain lion-killed ungulates. Of these documented kills, bighorn sheep comprised 1 percent of the mountain lion-killed ungulates and none of the wolf-killed ungulates.

In some conditions and environments, mountain lions have been documented to cause population-level impacts in bighorn sheep that occupy suitable habitat (Ross et al. 1997; Sawyer 
and Lindzey 2002). While mountain lion predation on bighorn sheep is widespread, it usually does not limit populations (IDFG 2010). Predation typically only has population-level effects on small bighorn sheep populations that are struggling due to other factors, such as disease or drought (IDFG 2010). Cassirer and Sinclair (2007) discussed mortality factors for bighorn sheep in Hells Canyon during the period of 1997 to 2003, during which time pneumonia was the most common cause of adult mortality (43 percent) and the primary factor limiting population growth. Mountain lion predation was the second most frequent source of adult mortality ( 27 percent), but did not significantly reduce the rate of population growth (Cassirer and Sinclair 2007).

\subsubsection{Habitat}

Current source habitat does not appear to be limiting for bighorn sheep, as much of the apparently suitable bighorn habitat appears to be unoccupied (HCBSRC 1997). IDFG (2010) identified that Idaho contains abundant habitat for bighorn sheep, the quality of which can be diminished by noxious weeds, conifer encroachment, roads and urban development, human disturbance, competition with livestock or other wild ungulates, and other factors. At scales below the watershed level, it is expected that the quality of habitat can have variances that cannot be detected at broader scales. The PRMP/FEIS (BLM 2008b) included successional modeling of both forested potential vegetation groups and shrub/grassland cover types. Comparable modeling was not completed for bighorn sheep habitat, since the information needed to model the change through time of grasslands, mountain mahogany, bitterbrush, and forest cover types with less than or equal to 10 percent canopy cover is sparse or unavailable, particularly in regards to proximity to rugged escape terrain.

The PRMP/FEIS did provide information on the general trends of vegetative response under each of the four alternatives, but it was not specific to domestic sheep allotments and bighorn sheep habitat. These generalized trends and conditions represent more than bighorn sheep habitat and do not account for the escape terrain and other special habitat features important to bighorn sheep. Bighorn sheep habitat is a subset of these trends for grassland response. The PRMP/FEIS also discussed the generalized trends for deciduous riparian vegetation under the four alternatives, which Wisdom and others (2000) identified as a special habitat feature. Again, bighorn sheep habitat is a subset of deciduous riparian vegetation.

Other factors that affect bighorn sheep habitat include patch dynamics of non-forest and forested habitats and their juxtapositions to each other. For example, suppression of wildfires for several decades has resulted in a reduced fire return interval and larger wildfires in some vegetation types. One effect that has occurred to some extent on the community types used by bighorn sheep is the increase of patch size of burned areas relative to historical conditions. However, without specific information on the juxtaposition of needed patches on the landscape (size and arrangement) for this species, comparing trends further with the species' needs is difficult. Patch dynamics, which vary historically, may affect dispersal between source habitat patches for bighorn sheep. Although bighorn sheep can use a diverse array of terrestrial and aquatic systems to move across the landscape, altering historical vegetation dynamics can potentially affect migratory routes. Large patch sizes of burned areas can open up forested and dense shrub areas to bighorn sheep. In some fire regimes, these large patch sizes would have been historically present; however, their location on the landscape shifts over time as post-fire succession occurs and a burned area returns to denser vegetation and new areas experience periodic disturbances. 
Livestock grazing practices can affect the balance between shrub and herbaceous vegetation and contribute to changes in the floristic composition of grass and shrub communities, both of which can result in altered fire regimes. These changes can also contribute to altering historical patch sizes.

In addition to patch dynamics, habitat quality is an important predictor of whether a species may be present. Habitat quality degradation through exotic weed invasion is a threat to habitat for this species. Depending on the type of exotic weed, food resources can be depleted and fire cycles disrupted, which can further alter species composition and structure. Livestock grazing can contribute to exotic weed invasions and damage to biological soil crusts, which can contribute to declines in source habitat quality.

Associated riparian areas within the ecosystem may also be affected by livestock grazing, with declines in habitat quality. Riparian systems can be particularly susceptible to livestock concentrations and grazing damage (Berry 1979). Defoliation, soil compaction, and floodplain water table subsidence due to channel widening or down-cutting have resulted in the loss of densely rooted graminoid and shrub species (Berry 1979; Kovalchik and Elmore 1992). Natural recovery of native riparian vegetation may be extremely slow, even with reductions in livestock grazing, because of deteriorating physical conditions of the stream during the last 150 years, dominance of exotic annuals within the riparian area, and loss of native seed sources (Clary et al. 1996). Livestock grazing can affect riparian vegetation by altering vegetation composition and seral stages. Excessive runoff from poor-condition sagebrush and grasslands and direct damage to riparian vegetation and stream banks can result from livestock grazing and trampling, road construction, and recreational use (Blaisdell et al. 1982). Often, lowered water tables resulting from heavy grazing pressure have modified or destroyed normal riparian vegetation and affected run-off and soil water storage capability within riparian areas, which has affected riparian ecosystem function. The ability of streams, associated vegetation, and wildlife populations to recover following reduced grazing stress appears to be situation-specific and related to site characteristics, degree of degradation, and availability of native plant materials (Shaw 1992; Krueper 1993).

Human activities are also primary sources of potential habitat degradation for bighorn sheep. Roads can be a source of direct mortality through vehicle strikes, and their presence and associated human uses can increase disturbance to bighorn sheep during critical periods throughout the year. Road construction can exacerbate effects from other risk factors, such as the spread of exotic species. In addition, off-highway vehicle use can facilitate the expansion of invasive species and adversely increase the potential for human disturbance and unlawful take. Roads and trails provide the primary access corridors for invasive plants, some of which are able to out-compete native species. This can result in a substantial change in the overall biological diversity of the affected area and changes in historical fire regimes. The susceptibility of source habitat to weed establishment is important to investigate at finer scales in relation to grounddisturbing activities, such as prescribed fire, roads, livestock grazing, and energy development or exploration.

No known studies, research, or peer reviewed literature has documented the effectiveness of BMPs from preventing contact and disease transmission when domestic sheep or goats graze within or adjacent to occupied bighorn sheep habitats. Effective separation between bighorn 
sheep and domestic sheep and goats, which minimizes the potential for contact and disease transmission, has been identified as the key management strategy for conservation of bighorn sheep (Wild Sheep Working Group 2012). The Partridge Creek Allotment is currently under a U.S. District Court Temporary Restraining Order, which temporarily closed the allotment. This was based on the Court's finding that the strategy relied on BMPs that were voluntary and could not be enforced by the BLM, and effectiveness was not backed by any supporting science.

Varying levels of effectiveness may result from BMPs that have a large buffer between active domestic sheep allotments and occupied bighorn sheep habitats and such a buffer reduces potential for disease transmission. Such allotments would also have to occur in open, gentle, non-bighorn sheep habitat where domestic sheep can be easily controlled and monitored, with a large buffer between the two species (Schommer 2009). This situation does not occur for three of the allotments analyzed in this SEIS (Partridge Creek, Marshall Mountain, and Hard Creek Allotments). These allotments are interspersed with forested areas, dense vegetation, and steep, rocky and rugged terrain. Control of domestic sheep, locating strays, and monitoring of bighorn sheep would be more difficult with these conditions, compared to areas that are open with moderate slopes. The Big Creek Allotment is more open and moderately sloped and has a large buffer between the nearest bighorn sheep occupied areas (Little Salmon River area of concern). In addition, implementing successful BMPs in a rangeland environment continuously year after year is very difficult, and the consequences of interspecies contact and disease outbreak may result in severe adverse impacts to local bighorn sheep populations.

The adoption of BMPs to prevent straying are designed to minimize the risk of contact with bighorn sheep; however, the adoption of such practices requires intensive monitoring efforts, vigilant herd management to reduce strays, and immediate response and effort to finding strays. The effectiveness of BMPs to reduce straying is not substantiated by research and may not always be effective. Stray domestic sheep are known to travel long distances and have been reported in areas not authorized for grazing or trailing or in areas during periods not identified for grazing.

\subsection{NATIVE AMERICAN TRIBAL USES}

This section supplements the description provide in the 2008 PRMP/FEIS, for Native American Tribal uses. As identified in Section 1.8 of this SEIS, the planning issue to be addressed is: Management of livestock grazing by the BLM, specifically domestic sheep and goats, may affect the availability of resources and uses (specially related to bighorn sheep) that are important to the interests and rights of the Nez Perce Tribe.

\subsubsection{Background}

During the mid to late $1800 \mathrm{~s}$, Indians were displaced from their original homes and relegated to reservations. The pressure to obtain land increased, especially with the discovery of gold, which increased the desire to obtain additional Indian land. Negotiations with various Indian groups resulted in land being ceded to the United States government through treaty, but with numerous rights reserved by the Indians. Treaties are negotiated contracts made pursuant to the Constitution of the United States. They take precedence over any conflicting state laws, as stated 
in the supremacy clause of the Constitution (Article 6, Clause 2). Treaty rights are not gifts or grants from the United States, but are bargained-for concessions. These rights are grants-of-right from the tribes, rather than to the tribes.

The unique relationship between the United States government and federally recognized Indian tribes is defined by treaties, statutes, executive orders, judicial decisions, and agreements. This relationship has created a special federal trust responsibility; as such, the BLM has the responsibility to identify and consider potential impacts of BLM actions on Indian trust resources (e.g., fish, game, water quality, plant resources, etc.). The BLM also has the responsibility to ensure that meaningful consultation and coordination concerning Tribal treaty rights and trust resources are conducted on a government-to-government basis with federally recognized tribes.

The federally recognized ${ }^{2}$ Nez Perce Tribe has long used natural resources and conducted its social and religious activities in the vicinity of the planning area. Between 1855 and 1863, the Nez Perce Tribe and the United States government signed various treaties and agreements that relinquished ownership of millions of acres of land to the government, and established and modified the Nez Perce Reservation to guarantee a permanent homeland for the Tribe. In 1855 , the United States negotiated a treaty with the Nez Perce Tribe (12 Stat. 957) that was ratified in 1859. Article 3 of this treaty reserves numerous rights, including hunting, and states in part:

The exclusive right of taking fish in all the streams where running through or bordering said reservation is further secured to said Indians; as also the right of taking fish at all usual and accustomed places in common with citizens of the Territory; and of erecting temporary buildings for curing, together with the privilege of hunting, gathering roots and berries, and pasturing their horses and cattle upon open and unclaimed land.

Taking of bighorn sheep is part of the reserved hunting right under Article 3.

The planning area is within the territory designated for use by the Nez Perce Tribe in 1967 by the Indian Claims Commission. ${ }^{3}$ The rights reserved under the 1855 Treaty apply to this territory. As stated in the Indian Claims Commission report": "Mountain sheep were found throughout the various mountains of the area, but were generally hunted by the Nez Perce in the following areas: ... (2) Riggers ${ }^{5}$, Idaho, area; ... (5) the upper Salmon River tributaries area."

The BLM manages portions of these ceded lands that are within the traditional use area of the Nez Perce Tribe. The treaties also reserve hunting, fishing, and gathering rights for members of the Nez Perce Tribe on federal land outside the boundaries of their reservation.

\footnotetext{
2 Indian Entities Recognized and Eligible to Receive Services From the United States Bureau of Indian Affairs. 67 Fed Reg. 46330 (July 12, 2002).

3 Indian Claims Commission in Docket 175181 . The Indian Claims Commission was ereated by the Indian Claims Commission Act of 1946, Pub. L. No. 79-726, ch. 959, Act of August 13, 1946, 60 Stat. 1049. The Act provided a forum for adjudication of Indian claims against the United States, many of the claims resulting from treaties.

Indian Claims Commission in Docket 17518 1, page 100.

${ }^{5}$ The Riggers area may be in reference to Riggins.
} 


\subsubsection{Existing Conditions}

Traditionally, socio-cultural values of the Nez Perce people reflect the close relationship with natural resources, including big game animals. In addition, socio-cultural values are intertwined with various natural resources and spiritual values are sometimes attributed to animals. For instance, the hunting of bighorn sheep is more than a subsistence activity. There are shared cultural beliefs involved that the sharing of a successful hunt strengthens family ties, maintains the connection of the Nez Perce people to the local ecology, forms a link to the past, and contributes, in part, to maintaining cultural continuity. Since hunting is a reserved right and is incorporated into the socio-cultural system, any change to these treaty-reserved opportunities has the potential to affect the socio-cultural system of the Nez Perce Tribe. Following is a brief description of the existing value of bighorn sheep use and the socio-cultural values to the Nez Perce Tribe.

The hunting of bighorn sheep currently does not have an economic market value, because the harvested resource is not sold on the open market. The Nez Perce Tribe does not track the number, the age class, and gender of the bighorn sheep that are taken. This cultural activity is accomplished at the family level, and is not reported to Tribal authorities. Rather, bighorn sheep are valued for their horns, hides, and meat. Chalfant (1974) states that "mountain sheep meat was considered as good as deer meat, and was therefore dried and cached for winter use." Currently, because of fewer bighorn sheep, there is less opportunity to obtain meat to supplement existing subsistence activities.

The horn of the bighorn sheep is highly prized and used in the building of bows. On bows made by the Nez Perce people, Spinden (1908) wrote: "[T] here were three kinds of bows, one simple and two sinew-backed. The finest bows were made from a single piece of mountain-sheep horn. A large horn was split and a slip taken out. This strip of horn retained its spiral coil and had to be steamed, stretched, and straightened by a long tedious process. After the horn had been shaped, a backing of deer sinew was added.... These bows were highly valued." Knowledge on how to build these bows has diminished within the Tribe. Although there have recently been efforts to regain this knowledge, there are fewer bighorn sheep horn available for Tribal members to continue this cultural tradition.

The Nez Perce Tribe area of interest historically lies between the Pacific Coast and the Great Plains. As such, the Tribe became accomplished traders and would trade their items with the Coastal and Plains people, acting as an intermediary between the two areas. Several of the items traded by the Nez Perce across this broad region included horn bows as well as spoons and bowls of mountain sheep horn (Walker 1967). At one time items resulting from the taking of bighorn were a trade item and contributed to the economy of the Nez Perce people.

Bighorn sheep, while important for sustenance, tools, and clothing, also have a spiritual role in Nez Perce culture. Located in the Bitterroot Valley near Missoula, Montana, in 1877 was "a huge horn of a mountain sheep, its tip partly imbedded in the trunk of the tree eight feet above the ground, [that] gave the tree its reputation for possessing a strong spiritual power, and the Salish and Sahaptin travelers felt its spell and often sought its aid in ensuring success in hunts, fights, or other ventures on which they were embarked" (Josephy 1971). 
Nez Perce Tribal ethnographer Josiah Pinkham summarized the value of the bighorn sheep to Nez Perce culture as follows:

Bighorn Sheep have provided spiritual guidance to the Nez Perce since time immemorial. Over the countless generations bighorn sheep have given much to help the Nez Perce survive. They have provided food and other necessary things for the Nez Perce. Its meat was cooked and eaten or dried to be eaten later in winter months or during travel. The highly nutritional organs are considered a delicacy to the Nez Perce. The heart, liver and intestines are still consumed by Nez Perce people today. Bighorn sheep hides are highly sought after for making clothing for shirts, dresses and leggings. Bighorn sheep bones were used for tools and games for the people.... It is hard for the Nez Perce people to maintain their cultural ties to the Salmon and Snake River canyons when the once most common large herbivore in these canyons has been reduced in number to essentially a museum population (Pinkham 2007).

As previously described, the population of bighorn sheep has been in decline for many years, reducing the opportunity for taking of bighorn sheep. With fewer animals to harvest, the opportunity to practice socio-cultural activities has been reduced, which in turn impacts the ability of the Nez Perce to exercise their treaty rights.

\subsection{LIVESTOCK GRAZING AND SOCIAL AND ECONOMIC CONDITIONS}

This section supplements the description from the 2008 PRMP/FEIS, for livestock grazing and social and economic conditions. As identified in Chapter 1 of this SEIS, the planning issue to be addressed is: Changes to management of livestock grazing by the BLM may affect the local economy.

\subsubsection{Background}

\subsubsection{Livestock Grazing Background}

The BLM manages livestock grazing on public land under the Taylor Grazing Act of June 28, 1934, as amended; the FLPMA, as amended by the Public Rangeland Improvement Act of 1978; the Public Rangelands Improvement Act of 1978; and Public Land Orders, Executive Orders, and agreements that authorize the Secretary to administer livestock grazing of specified lands under the Taylor Grazing Act or other authority as specified.

Land use plans establish allowable resource uses, related levels of use, and areas of use. Livestock grazing is a resource use managed and authorized in accordance with BLM grazing regulations that can be found under 43 CFR 4100 . Under these regulations, the area of use is an allotment, an area of land designated and managed for grazing of livestock, and the level of use is detailed in AUMs, which is defined as the amount of forage necessary to sustain one cow and her calf, or five sheep for a period of 1 month. The number of livestock authorized for a particular allotment is determined by the quantity of forage that is made available for livestock in Animal Unit Months (AUMs). 
Applicants (grazing lessees) who meet qualifications listed in 43 CFR 4110 may apply for and receive a grazing lease or permit on an allotment for 10 years. A grazing lease or permit is a document that authorizes grazing use on the public lands under the Taylor Grazing Act. It specifies mandatory terms and conditions, including the kind and number of livestock, the period(s) of use, the allotment(s) to be used, and the amount of use in AUMs. Other terms and conditions may include class of livestock, breed of livestock, and specific management requirements.

The Rangeland Reform process of 1994 modified the federal Range Management regulations by adding Subpart 4180 (Fundamental of Rangeland Health and Standards and Guidelines for Grazing Administration); and in 1997, the BLM Idaho State Director approved the Idaho Standards for Rangeland Health and Guidelines for Livestock Grazing (BLM 1997). These standards and guidelines are intended to provide a clear statement of agency policy and direction for those who use public lands for livestock grazing and who are responsible for their management and accountable for their conditions. The process by which standards and guidelines for grazing administration are implemented is outlined in 43 CFR 4180.2. In Idaho, the BLM assesses allotments to ensure that livestock grazing use is compatible with meeting standards for rangeland health in eight areas: watersheds, riparian areas and wetlands, stream channel/floodplains, native plant communities, seedings, exotic plant communities other than seedings, water quality, and threatened and endangered plants and animals.

\subsubsection{Social and Economic Background}

BLM management of recreation and forage for livestock grazing generates employment and income in the surrounding communities and counties, and generates revenue that is returned to the federal treasury or is used to fund additional activities on the ground to accomplish land management objectives. Economic effects are examined in terms of employment and income generated from the various alternatives. Social effects are examined in terms of amenity and social values.

Bighorn sheep-associated recreation, including wildlife viewing and hunting, contributes to the economy and river-related public enjoyment of the Main Salmon River and Little Salmon River canyons. For grazing use, adjustments or curtailment of domestic sheep grazing on BLM allotments would impact residents with regional connections unique to the sheep industry in revenue and the traditions of livestock operations.

Multiple statutes, regulations, and executive orders identify the general requirement for the application of economic and social evaluation in support of BLM planning and decision making. These include, but are not limited to, the Multiple-Use Sustained Yield Act of 1960 (74 Stat. 215: 16 USC 528-531), the NEPA (83 Stat. 852; 42 USC 4321, 4331-4335, 4341-4347), and the FLPMA. In addition, the preparation of NEPA documents is guided by CEQ regulations for implementing the NEPA [40 CFR 1500-1508], which requires that consequences to the human environment be analyzed and disclosed. The extent to which these environmental factors are analyzed and discussed is related, in part, to the nature of public comments received during scoping. As a result of these comments, economic impacts and non-market and social values are considered in this evaluation. 
Many of the costs and benefits associated with federal management are not quantifiable in financial terms (e.g., the benefit to wildlife from habitat improvement from a project). These costs and benefits are described qualitatively in the Non-market and Social Values sections of this document. Title 40 CFR 1502.23 indicates the following:

For the purposes of complying with the Act, the weighing of the merits and drawbacks of the various alternatives need not be displayed in a monetary cost-benefit analysis and should not be when there are qualitative considerations.

In addition, Executive Order 12898 (Environmental Justice) issued in 1994 requires federal agencies to identify and address any adverse human health and environmental effects of agency programs that disproportionately impact minority and low-income populations; as well as directs agencies to consider patterns of subsistence hunting and fishing when an agency action may affect fish or wildlife.

\subsubsection{Existing Conditions}

\subsubsection{Livestock Grazing Existing Conditions}

The CFO previously authorized domestic sheep grazing on four allotments (see Map 2 in Appendix D), these are Partridge Creek, Marshall Mountain, Hard Creek, and Big Creek, totaling 19,405 acres. Goat grazing has never been a primary use of public lands in the CFO, although there may have been a few goats included in sheep bands from time to time. It is not expected that applications for grazing leases would be received where goats would be the primary grazing animals. Carlson Livestock Company has two BLM grazing leases, one for Marshall Mountain and one for Partridge Creek. Soulen Livestock Company holds one BLM grazing lease that authorizes grazing use on both the Hard Creek and Big Creek allotments. Specific information for these four domestic sheep allotments is summarized in Table 3-4.

\begin{tabular}{|l|c|c|c|c|}
\hline Table 3-4: Allotments with Sheep Grazing \\
\hline \multicolumn{1}{|c|}{ Allotment Name } & Partridge Creek & Marshall Mountain & Hard Creek & Big Creek \\
\hline BLM Acres & 9,544 & 4,212 & 5,210 & 439 \\
\hline Lessee Name & $\begin{array}{c}\text { Carlson Livestock } \\
\text { Company }\end{array}$ & $\begin{array}{c}\text { Carlson Livestock } \\
\text { Company }\end{array}$ & $\begin{array}{c}\text { Soulen Livestock } \\
\text { Company }\end{array}$ & $\begin{array}{c}\text { Soulen Livestock } \\
\text { Company }\end{array}$ \\
\hline Expiration Date & $2 / 28 / 2014$ & $2 / 28 / 2016$ & $2 / 28 / 2019$ & $2 / 28 / 2019$ \\
\hline Season of Use & $\begin{array}{c}4 / 11 \text { to } 7 / 15 \\
10 / 15 \text { to } 11 / 30\end{array}$ & $07 / 5$ to $08 / 04$ & $6 / 15$ to $7 / 15$ & $6 / 1$ to $10 / 30$ \\
\hline Number of Sheep & 833 & 815 & 1,050 & 8,000 \\
\hline $\begin{array}{l}\text { Permitted Sheep Use } \\
\text { in AUMs }\end{array}$ & 431 & 166 & 218 & 81 \\
\hline $\begin{array}{l}\text { Current Status } \\
\text { (until SEIS is } \\
\text { completed) }\end{array}$ & $\begin{array}{c}\text { District Court Temporary } \\
\text { Restraining Order } \\
10 / 14 / 2009\end{array}$ & $\begin{array}{c}\text { Temporary Closure } \\
\text { by BLM Decision } \\
3 / 15 / 2011\end{array}$ & $\begin{array}{c}\text { Lessee has } \\
\text { voluntarily taken } \\
\text { non-use }\end{array}$ & $\begin{array}{c}\text { Lessee has } \\
\text { voluntary taken } \\
\text { non-use }\end{array}$ \\
\hline
\end{tabular}

The total permitted sheep use on these four allotments is 896 AUMs on 19,405 acres of public land. Both Lessees hold USFS, Idaho Department of Lands, and BLM grazing leases or permits 
that are used in conjunction with grazing of private land to provide forage for their domestic sheep through the year.

Carlson Livestock Company historically used their private land in conjunction with lower elevation land in the BLM's Partridge Creek Allotment and USFS land managed by the Nez Perce National Forest on the north side of the Salmon River as fall, winter, and spring use areas. In late spring, the sheep bands moved to higher elevations in the Partridge Creek Allotment and onto other USFS lands managed by the Payette National Forest. The bands used various USFS allotments and the BLM's Marshall Mountain Allotment during the summer and early fall. In the fall, sheep bands were herded down in elevation, making their way back to the wintering areas along the Salmon River.

Soulen Livestock Company moved sheep through the Hard Creek Allotment in early summer on their way to grazing allotments on the Payette National Forest. Sheep may use minor BLM acreage in the Big Creek Allotment during the summer or fall either as longer term pasture for a sheep band or in a transitory nature, as bands moved through the privately owned lands on the way to allotments managed by the Payette National Forest.

\section{Partridge Creek Allotment}

The Partridge Creek Allotment is located approximately 7 miles east of Riggins, Idaho (see Map 2 in Appendix D). The 9,544-acre BLM allotment is intermingled with, and used for livestock grazing in conjunction with other land ownership, including: 5,845 acres owned by Carlson Livestock Company; and 640 acres managed by Idaho Department of Lands. Carlson Livestock Company has held a BLM grazing lease on the allotment since 1937, and has used it every year up until 2009.

The BLM completed a Rangeland Health Assessment for the Partridge Creek Allotment during the spring and summer of 2003; and determined that the allotment was meeting all standards and guidelines. Subsequently the BLM issued Carlson Livestock Company a renewed 10-year grazing lease, which expires on February 28, 2014.

In 2007, the Idaho State Governor asked federal and state agencies to work with sheep producers to come up with a strategy to reduce the potential for contact between domestic and bighorn sheep (IDFG ISDA 2007). The 2008 BLM PRMP/FEIS identified a concern for disease transmission between bighorn sheep and domestic sheep on BLM allotments. In an effort to be proactive regarding domestic and bighorn sheep concerns on the Salmon River, the BLM, Carlson Livestock Company, IDFG, Idaho Department of Lands, and Idaho State Department of Agriculture developed a "Strategy for Reducing Risk of Contact between Bighorn Sheep and Domestic Sheep in the Salmon River Area" (ISDA 2009), which detailed management practices to:

- Reduce the risk of contact between bighorn sheep and domestic sheep

- Increase communication and management coordination with respect to bighorn sheep observations

- Improve management of straying domestic sheep

- Respond to contact incidents between bighorn sheep and domestic sheep 
Carlson Livestock Company agreed to implement the strategy on all lands used in and adjacent to the allotment, including private lands. The cooperators signed the strategy in April 2009, and it was implemented during the 2009 grazing season as an interim measure until completion of this SEIS.

Both Western Watersheds Project (WWP) and the Nez Perce Tribe expressed concern that the strategy would not adequately protect bighorn sheep. Therefore, WWP litigated the BLM in Federal District Court in late 2009 in an attempt to force closure of the Partridge Creek Allotment to sheep grazing. After a hearing by the United States District Court for the District of Idaho, the District Judge invoked a Temporary Restraining Order on the BLM to temporarily close the Partridge Creek Allotment. This was based on the Court's finding that the strategy relied on best management practices that were voluntary and could not be enforced by the BLM, and were not backed by any supporting science. Later, the BLM agreed to extend the temporary closure until the SEIS was completed. The restraining order only applies to BLM land. Therefore, Carlson Livestock Company may still graze sheep on their private land and on permitted Idaho Department of Lands, both of which adjoin the Partridge Creek Allotment.

\section{Marshall Mountain Allotment}

The Marshall Mountain Allotment is located approximately 20 miles east of Riggins, Idaho, and 2 miles south of the Salmon River (see Map 2 in Appendix D). All 4,212 acres of the allotment are managed by the BLM. Carlson Livestock Company has held a grazing lease on the allotment since 1981 and has used it every year up until 2011, except when taking non-use in 2000-2001. The allotment is a part of the forage base used in conjunction with the BLM's Partridge Creek allotment, the Carlson's Idaho Department of Lands grazing permit, and grazing permits for Nez Perce and Payette National Forest allotments.

The BLM conducted a Rangeland Health Assessment on the allotment during the field season of 2004; and determined that the allotment was meeting all standards and guidelines. Subsequently the BLM renewed Carlson Livestock Company's grazing lease, which expires on February 28, 2016.

Based on growing concerns regarding bighorn sheep, the BLM contacted Carlson Livestock Company in 2010 to see if they would consider taking voluntary non-use on the Marshall Mountain Allotment until such time that the SEIS was completed. Because Carlson Livestock Company wished to use the allotment for the 2011 grazing season in conjunction with their adjoining USFS allotments, they decided not to take voluntary non-use.

In early 2011, due to growing concerns regarding potential impacts to bighorn sheep, the Cottonwood Field Manager issued a "Notice of Potential Interim Closure of Domestic Sheep Grazing on the Marshall Mountain Allotment." This decision was based on the latest information and science regarding the risk of contact between domestic sheep and wild bighorn sheep, and potential transmission of disease to bighorn, and on the fact that this allotment is within bighorn sheep distribution habitat identified by the IDFG. The allotment also provides summer source habitat for bighorn sheep and occurs in close proximity to bighorn sheep CHHRs identified by the Payette National Forest. 
On March 15, 2011, after considering the public's comments and the information regarding risks to bighorn sheep, the Cottonwood Field Manager decided to temporarily close the allotment to domestic sheep grazing until the SEIS could be completed. Carlson Livestock Company filed a timely notice of appeal and a petition to stay, which was denied by the United States Department of the Interior Office of Hearings and Appeals on June 2, 2011. Carlson Livestock Company subsequently withdrew its appeal, and the Marshall Mountain Allotment has been temporarily closed to sheep grazing until such time that the SEIS is completed.

\section{Hard Creek Allotment}

The Hard Creek allotment is located in the Little Salmon River drainage, approximately 15 miles south of Riggins, Idaho, east of Highway 95 (see Map 2 in Appendix D). The Hard Creek Allotment comprises 5,210 acres of public land managed by the BLM. Soulen Livestock Company has held a grazing lease on the allotment since 1975 and used the allotment each year until 2005. They have taken voluntary non-use on the allotment since that time; however, this was not directly related to the bighorn issue. Soulen Livestock Company was having problems with wolf depredation on domestic sheep on the Hard Creek Allotment, so wished to avoid the problem area until the depredation could be addressed. In 2006, information became available to the BLM that highlighted the risk associated with grazing sheep in bighorn sheep habitat; because Soulen Livestock Company was already taking voluntary non-use on the Hard Creek Allotment, the BLM did not issue a temporary closure.

The BLM completed a Rangeland Health Assessment on the allotment during the field season of 2004; and determined that the allotment was meeting all standards and guidelines. Subsequently the BLM renewed Soulen Livestock Company's grazing lease, which expires on February 28, 2016.

\section{Big Creek Allotment}

The Big Creek Allotment is located in the Little Salmon River drainage, approximately 5 miles southeast of New Meadows, Idaho (see Map 2 in Appendix D). The allotment consists of four small isolated tracts of BLM managed land, and is surrounded by private land. The Big Creek Allotment has some unique management challenges due to its intermingled land patterns. Since 1975, Soulen Livestock Company has held a BLM grazing lease on the allotment, and made use of the allotment from 1975 through 2006 and in 2008. The allotment was not utilized in 2007 , and Soulen Livestock Company has taken voluntary non-use from 2009 to the present. Due to the amount of private land, usually used in conjunction with the allotment, Soulen Livestock Company can effectively graze on private land without grazing the BLM managed portions. In 2008, new information became available to the BLM that highlighted the risks associated with grazing domestic sheep in bighorn sheep habitat; because Soulen Livestock Company was already taking voluntary non-use, the BLM did not issue a temporary closure.

The BLM completed a Rangeland Health Assessment on the allotment during the field season of 2008, and found that the allotment was meeting all standards and guidelines. Subsequently the BLM renewed Soulen Livestock Company's grazing lease, which expires on February 28, 2021. 
The Nez Perce National Forest historically managed and authorized sheep grazing on the Allison-Berg Allotment, whose southern boundary is the Salmon River. The Salmon River also forms the northern boundary of the BLM Partridge Creek Allotment (see Map 9 in Appendix D). The WWP litigated the Nez Perce National Forest in District Court regarding grazing authorizations for this allotment due to concerns for disease transmission to bighorn sheep from domestic sheep. On November 13, 2007, the Idaho District Court ordered the Nez Perce National Forest not to permit domestic sheep grazing on the allotment. Closing the Allison-Berg Allotment removed access to grazing lands that historically provided winter and spring grazing for Carlson Livestock Company.

In July 2010, the Payette National Forest completed a Final SEIS and ROD to amend the Payette National Forest Plan in order to maintain the habitat necessary to support viable populations of bighorn sheep. The ROD implemented a phased closure of a number of sheep allotments from 2010 to 2013. The USFS allotment closures impacted the year-round sheep operations of both Soulen Livestock Company and Carlson Livestock Company.

The July 2010 Payette National Forest ROD determined that Soulen Livestock Company could graze sheep on three USFS allotments in 2011: Grassy Mountain, Vance Creek, and the northeast 75 percent of Hershey Lava - see Map 10. Beginning in 2012 and in subsequent years, Soulen Livestock Company would no longer be authorized to graze sheep on these three allotments. In addition, the ROD determined that starting in 2011, Carlson Livestock Company, would no longer be authorized to graze sheep on the three USFS allotments for which they held permits: Marshall Mountain, French Creek, and the western 75 percent of Bear Pete - see Map 10. Beginning in 2012 and in subsequent years, Carlson Livestock Company would not be authorized to graze any sheep on the remainder of the Bear Pete allotment.

\subsubsection{Social and Economic Existing Conditions}

Certain defining features of every area influence and shape the nature of local economic and social activity. Among these are population characteristics, the presence of or proximity to large cities or regional population centers, types of longstanding industries such as agriculture and forestry, area racial and cultural characteristics, predominant land and water features, and unique area amenities. The CFO operates as a steward of many of these area resources and opportunities, thus playing a principal role in the community. This discussion gives further insight as to the character and extent of these community connections as they relate to the proposed action and alternatives.

\section{Affected Area}

The CFO lies within Latah, Clearwater, Nez Perce, Lewis, Idaho, and Adams counties of northcentral Idaho. Social and economic characteristics of this area are reported in the Cottonwood PRMP/FEIS (Section 3.5.3). This assessment focuses specifically on the BLM's future management of domestic sheep grazing on allotments in Idaho and Adams counties. In addition, Washington County is included in the impact area due to economic connections between operators on the CFO allotments and the economy in Washington County. The area social and 
economic characteristics are dependent on the extent of the area examined, thus area information is presented for the potentially affected counties and smaller communities within Idaho and Adams counties, respectively: Riggins Census County Division (CCD) and New Meadows CCD (Figure 3-3).

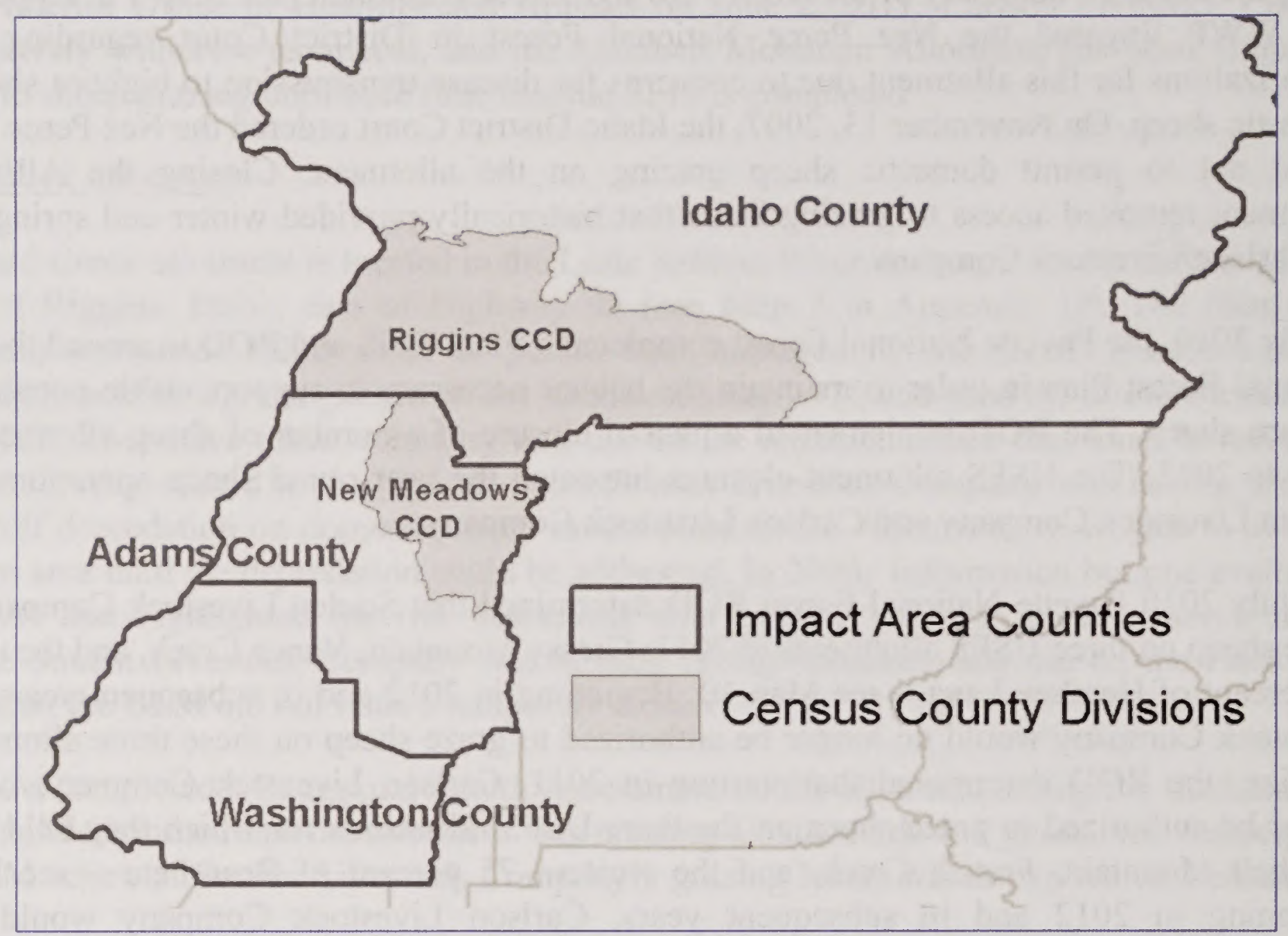

Figure 3-3: Impact Area Counties and Component Census County Divisions

\section{Population and Demographic Change}

From 2000 to 2010 , the population of the three-county impact area grew from 28,964 to 29,994 , an increase of 5 percent (Table 3-5). However, most of this growth was associated with Adams County. While Adams County and Idaho County grew by 13 and 3 percent, respectively, Riggins CCD decreased by 18 percent. The growth seen in the three-county area was less than the national growth rate and the State of Idaho (8 and 18 percent, respectively) (U.S. Department of Commerce, Census Bureau 2012).

\begin{tabular}{|l|c|c|c|c|}
\hline Table 3-5: Population Change \\
\hline \multicolumn{1}{|c|}{ Assessment Area } & $\begin{array}{c}\text { Population } \\
\mathbf{2 0 1 0}\end{array}$ & $\begin{array}{c}\text { Population } \\
\mathbf{2 0 0 0}\end{array}$ & $\begin{array}{c}\text { Population Change } \\
\mathbf{( 2 0 0 0 - 2 0 1 0 )}\end{array}$ & $\begin{array}{c}\text { Population Percent Change } \\
\text { (2000-2010) }\end{array}$ \\
\hline United States & $303,965,272$ & $281,421,906$ & $22,543,366$ & 8 \\
\hline Impact Area & 29,994 & 28,964 & 1,030 & 4 \\
\hline State of Idaho* & $1,526,797$ & $1,293,953$ & 232,844 & 18 \\
\hline Adams County* & 3,942 & 3,476 & 466 & 13 \\
\hline New Meadows CCD & 1,441 & 1,298 & 143 & 11 \\
\hline Idaho County & 15,947 & 15,511 & 436 & 3 \\
\hline
\end{tabular}


Table 3-5: Population Change

\begin{tabular}{|l|c|c|c|c|}
\hline \multicolumn{1}{|c|}{ Assessment Area } & $\begin{array}{c}\text { Population } \\
\mathbf{2 0 1 0}\end{array}$ & $\begin{array}{c}\text { Population } \\
\mathbf{2 0 0 0}\end{array}$ & $\begin{array}{c}\text { Population Change } \\
\mathbf{( 2 0 0 0 - 2 0 1 0 )}\end{array}$ & $\begin{array}{c}\text { Population Percent Change } \\
\text { (2000-2010) }\end{array}$ \\
\hline Riggins CCD & 1,144 & 1,397 & $(253)$ & -18 \\
\hline Washington County' & 10,105 & 9,977 & 128 & 1 \\
\hline 'impact area
\end{tabular}

Identifying concentrations of minority and ethnic group populations are required in order to evaluate environmental justice. Recent data from the annual American Community Survey for 2006-2010 indicate that counties in the impact area contain shares of several racial and ethnic groups that are greater than shares in the in the $\operatorname{state}^{6}$ (U.S. Department of Commerce, Census Bureau 2012). For instance, the percentage of those identifying themselves as Native American in Idaho County and Adams County was greater than the total for the state of Idaho (Table 3-6).

\begin{tabular}{|l|c|c|c|c|c|c|c|c|}
\hline Table 3-6: & Racial and Hispanic Composition of 2010 Population (in percentages) \\
\hline \multicolumn{1}{|c|}{ Location } & $\begin{array}{c}\text { White } \\
\text { Alone }\end{array}$ & $\begin{array}{c}\text { Black or } \\
\text { African } \\
\text { American } \\
\text { Alone }\end{array}$ & $\begin{array}{c}\text { American } \\
\text { Indian and } \\
\text { Alaska } \\
\text { Native Alone }\end{array}$ & $\begin{array}{c}\text { Asian } \\
\text { Alone }\end{array}$ & $\begin{array}{c}\text { Native } \\
\text { Hawaiian and } \\
\text { Other Pacific } \\
\text { Islander Alone }\end{array}$ & $\begin{array}{c}\text { Some } \\
\text { other } \\
\text { race } \\
\text { alone }\end{array}$ & $\begin{array}{c}\text { Two or } \\
\text { more } \\
\text { races }\end{array}$ & $\begin{array}{c}\text { His- } \\
\text { panic } \\
\text { Origin }\end{array}$ \\
\hline United States & 74.0 & 12.5 & 0.8 & 4.7 & 0.2 & 5.5 & 2.4 & 15.7 \\
\hline Impact Area & 92.6 & 0.1 & 2.2 & 0.5 & 0.1 & 1.8 & 2.7 & 6.6 \\
\hline State of Idaho & 92.2 & 0.6 & 1.2 & 1.2 & 0.1 & 2.2 & 2.4 & 10.6 \\
\hline Adams County & 91.2 & 0.1 & 2.8 & 0.4 & 0.6 & 0.1 & 4.8 & 0.9 \\
\hline $\begin{array}{l}\text { New Meadows } \\
\text { CCD }\end{array}$ & 91.2 & 0.1 & 2.5 & 1.2 & 0.4 & 0.1 & 4.4 & 0.3 \\
\hline Idaho County & 94.1 & 0.1 & 2.6 & 0.1 & 0.0 & 0.6 & 2.5 & 2.4 \\
\hline Riggins CCD & 96.0 & 0.0 & 0.0 & 0.1 & 0.0 & 0.0 & 3.9 & 2.5 \\
\hline $\begin{array}{l}\text { Washington } \\
\text { County }\end{array}$ & 90.6 & 0.2 & 1.4 & 1.1 & 0.0 & 4.5 & 2.1 & 1.3 \\
\hline
\end{tabular}

\section{Economic Specialization and Employment}

Employment within impact area counties and the state are distributed among industry sectors (see Figure 3-4) (IMPLAN 2010). Identification of employment specialization within the three impact area counties provides a frame of reference for impacts under the alternatives. Specialization is examined using the ratio of the percent employment in each industry in the region of interest (impact area counties) to the percent of employment in that industry for a larger reference region (Idaho). For a given industry, when the percent employment in the analysis region is greater than in the reference region, local employment specialization exists in that industry (USFS 1998). Of particular interest are industries where specialization occurs within industries related to sheep grazing and recreation. The subsector with domestic sheep grazing represents agricultural employment in animal production, except cattle, poultry, and eggs, and

${ }^{6}$ Race and ethnicity are separated sinee Hispanics ean be of any race. 
represents 0.8 percent of impact area employment. The recreation-related sectors represent portions of larger sectors specifically related to recreation (Marcouiller and Xia 2008).

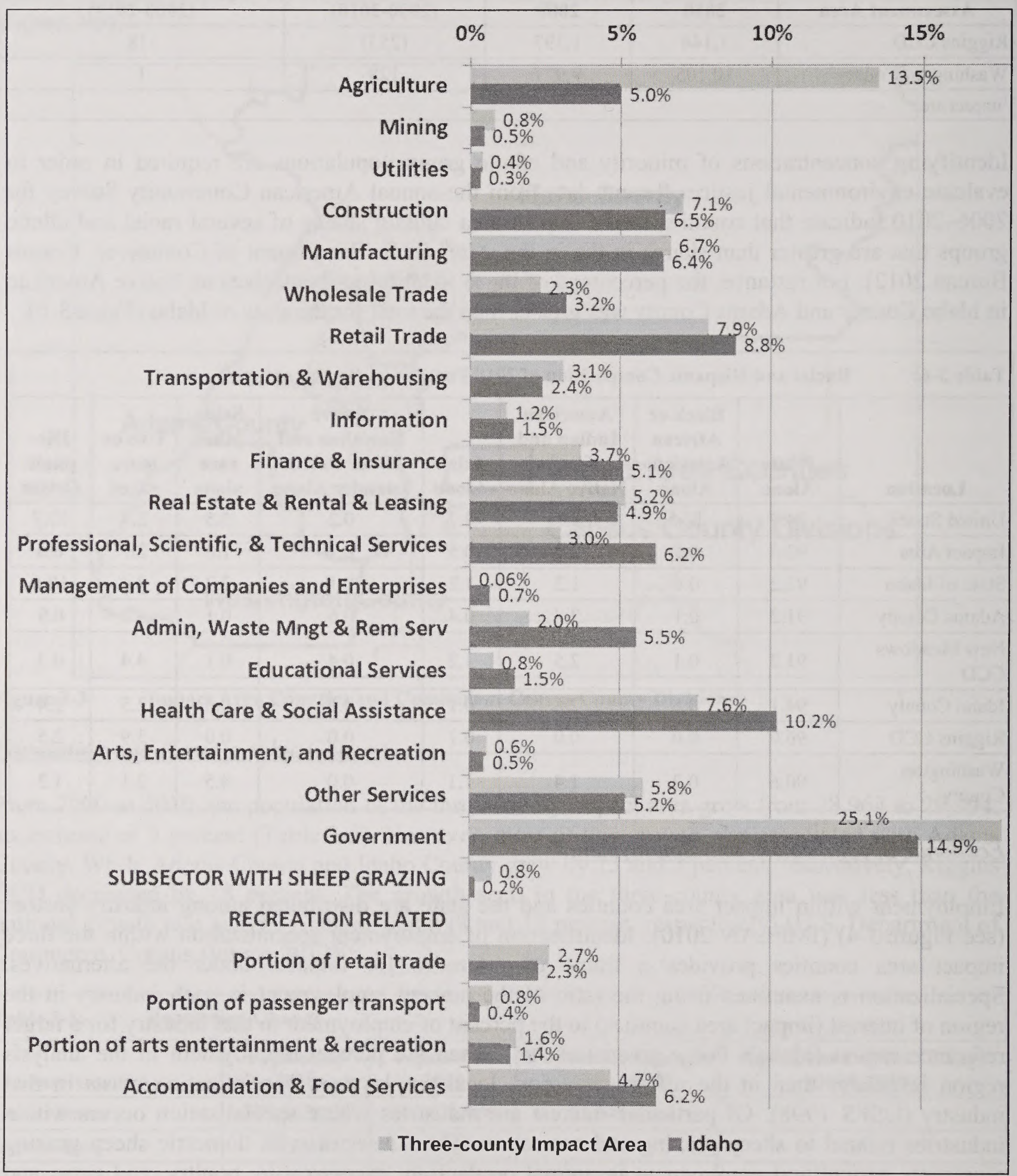

Figure 3-4: $\quad$ Impact Area Employment Distribution (IMPLAN 2010) 
Using this criterion in conjunction with 2010 data, impact area counties can be characterized as most specialized with respect to the agriculture, government, and the transportation and warehousing sectors (shares of total employment in these sectors are respectively, 2.7, 1.7 and 1.2 percent greater than shares in the state) (IMPLAN 2010). Contributions from grazing and recreation on the $\mathrm{CFO}$ represent only a portion of the economic activity reflected in industry sectors (IMPLAN 2010).

Between 1998 and 2009 total employment in the three-county impact area has increased from 5,236 to 5,408 (down from 6,518 jobs in 2006). Much of this growth is attributable to employment in the services-related sectors (U.S. Department of Commerce, Census Bureau 2011). Services-related sectors consist of utilities; wholesale trade; retail trade; transportation and warehousing; information; finance and insurance; real estate and rental and leasing; professional, scientific, and technical; management of companies and enterprises; administrative and support services; educational services; health care and social assistance; arts, entertainment, and recreation; accommodation and food services; and other services. Non-services related sectors consist of mining, construction, manufacturing, agriculture, forestry, fishing, and hunting (EPS-HDT 2012).

From 1998 to 2009 , employment in services-related sectors increased from 70.1 percent to 73.4 percent, while employment in the non-services-related sectors decreased from 29.9 percent to 26.6 percent (U.S. Department of Commerce, Census Bureau 2011). Thus, the services-related sectors, historically important to the area's economy, have increased in importance.

\section{Economic Well-Being and Poverty}

In general, wages for service-related jobs do not pay as much as non-service jobs (Figure 3-5). In 2010, within the three-county impact area, the services and non-services-related sectors paid average annual wages of $\$ 26,285$ and $\$ 30,554$, respectively (U.S. Department of Labor 2011). Thus, increases in employment in sectors associated with lower wages alongside decreases in sectors associated with higher wages could indicate a decrease in area economic well-being. However, it is not clear whether decreases in economic well-being have resulted from increases in services-related sector employment, since higher labor force participation in the servicesrelated sectors by groups such as women, minorities, and others taking a second job in the services-related sectors could increase the overall importance of certain sectors over others. In addition, population and employment changes are related to natural amenities often provided by public lands (Knapp and Graves 1989; Clark and Hunter 1992; Treyz et al. 1993; Mueser and Graves 1995; McGranahan 1999; Lewis et al. 2002). For instance, people might move to an area to take a services-related sector job despite the lower wage, because of the unique natural and cultural amenities. The CFO operates as a steward of many of these natural amenities and consequently supports a portion of area population and employment growth. 


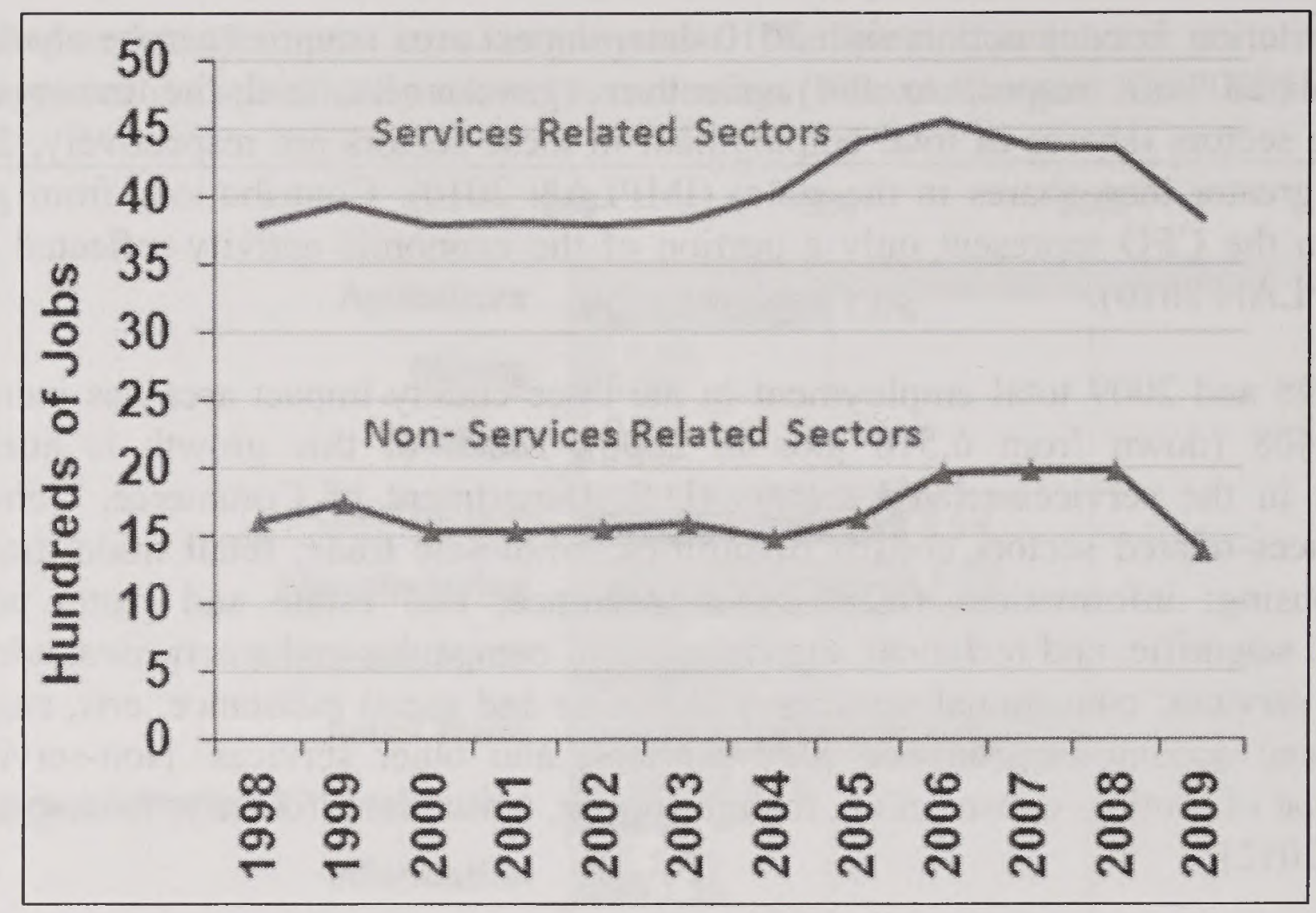

Figure 3-5:

Services and Non-services Employment History (U.S. Department of Commerce, Census Bureau 2011) ${ }^{7}$

Total personal income (TPI) and per capita personal income (PCPI) are useful measures of economic well-being. From 1970 to 2010, annual TPI in the three-county impact area increased from $\$ 441,246$ to $\$ 858,558$, and annual PCPI increased from $\$ 18,741$ to $\$ 28,185$ (all measures adjusted for inflation to 2011 dollars). This translates to a TPI increase of 95 percent and a PCPI increase of 50 percent over this time period (U.S. Department of Commerce, Bureau of Economic Analysis 2011). While PCPI is a useful measure of economic well-being, it should be examined alongside changes in real earnings per job. Since PCPI includes income from 401(k) plans, as well as other non-labor income sources like transfer payments, dividends, and rent, it is possible for per capita income to rise, even if the average wage per job declines over time. While PCPI rose 50 percent between 1970 and 2010, average earnings per job fell 18 percent (from $\$ 35,553$ to $\$ 28,986$; values adjusted for inflation to 2011 dollars) (U.S. Department of Commerce, Bureau of Economic Analysis 2011). Thus while PCPI bounced back after job loss in the early 1980s, real earnings per job decreased.

From 1991 to 2007, average annual unemployment rates in the three-county impact area fell with national and state levels, from 12.1 to 4.7 percent. Since 2007, unemployment has continued to follow state and national trends and has risen to 11.7 percent in 2011 (U.S. Department of Labor 2012). New jobs created in an area are filled from two principal sources: local unemployment and in-migration. If unemployment remains high, new jobs are likely to be filled by local area residents; however, if unemployment falls, new jobs could be filled more often by new area residents.

\footnotetext{
${ }^{7}$ The numbers are not directly comparable to the IMPLAN numbers in Error! Reference source not found. since IMPLAN data nclude government, farm and proprietor employment in addition to wage and salary employment. The IMPLAN data also includes estimates for non-diselosures that similarly include farm and proprictor employment in addition to wage and salary employment.
} 
Estimates of the share of people living under the poverty level in the New Meadows and Riggins CCDs ( 16 and 23 percent, respectively) were greater than their respective counties (12 percent in Adams County and 19 percent in Idaho County) and the state of Idaho (14 percent) (U.S. Department of Commerce, Census Bureau 2012).

\section{Components of Personal Income}

Further examination of personal income provides insight to the area economy and its connection to the CFO-managed lands and resources. There are three major sources of personal income: (1) labor earnings or income from the workplace, (2) investment income, or income received by individuals in the form of rent, dividends, or interest earnings, and (3) transfer payment income or income received as Social Security, retirement and disability, or Medicare and Medicaid.

Non-labor earnings were slightly greater than labor earnings in the three-county impact area, accounting for 50.2 percent of all income in 2010 (labor earnings accounted for 49.8 percent) (U.S. Department of Commerce, Bureau of Economic Analysis 2011). The government and agriculture sectors were the largest components of labor income in 2010 in the three-county impact area, containing 25.1 and 13.5 percent of total labor income, respectively (IMPLAN 2010). TPI from labor earnings has decreased from 1970 to 2010 (from 73.5 to 49.8 percent) while the share of non-labor income has risen (from 26.5 to 50.2 percent). As a share of TPI, investment income and transfer payments rose from 15.6 to 22.7 and 10.8 to 27.5 percent, respectively, over this 40 -year time period (U.S. Department of Commerce, Bureau of Economic Analysis 2011).

These patterns reflect the importance of the aging population, which is more likely to have investment earnings than younger adults are. As the population of the area continues to age, the share of income from these non-labor sources should continue to rise as long as residents remain in the area after retirement or new retirees move in. As noted above, the development of rural recreation and retirement-destination areas are related to natural amenities often provided by public lands. The CFO operates as a steward of many of these natural amenities and consequently supports a portion of non-labor income.

\section{Recreational Use}

The habitat of the Salmon and Hells Canyon bighorn sheep herds includes public lands in the Lower Salmon River Special Management Recreation Area (SRMA), for which the CFO manages to provide structured recreational opportunities (i.e., activity, experience, and benefit opportunities). The Lower Salmon River SRMA encompasses 6,899 acres of the Salmon River from the Vinegar Creek (river mile 112.5) to the Hammer Creek (river mile 52.5) recreation sites. The confluence with the Little Salmon River in Riggins is at river mile 87.5. The Middle Salmon River Canyon is a Watchable Wildlife Area that includes 80 miles of the Salmon River east of Riggins, where Rocky Mountain bighorn sheep are often seen. A Special Recreation Permit (SRP) is required for commercial boating use of the Salmon River. No guides are licensed to hunt bighorn sheep in habitat within the Lower Salmon River SRMA, so no commercial permits are available or would be affected by any of the alternatives. 
Wildlife-related recreation is important to Idaho's economy and culture. The IDFG (2010) identified that many people who have no interest in hunting bighorn sheep, yet are very interested in learning more about them and observing bighorn sheep in the wild. The outdoor recreation industry capitalized on this interest. For example, river rafting and jet boat touring companies frequently use the opportunity to view bighorn sheep to promote their trips. Bighorn sheep are among Idaho's most treasured wildlife species and there is widespread fascination with this majestic animal. Approximately, 0.75 million people spent 263 million dollars while participating in wildlife viewing in Idaho in 2006 (IDFG 2010).

The federal Watchable Wildlife Program is a cooperative, nationwide effort among 13 organizations, including the BLM that fosters the conservation of wildlife and wildlife habitats by:

- Providing enhanced opportunities for the public to enjoy wildlife

- Promoting learning about wildlife and habitat needs

- Contributing to local economies

- Enhancing active public support for resource conservation

The Middle Salmon River Canyon is one of four Watchable Wildlife Areas in the CFO. It includes 80 miles of the Salmon River, where Rocky Mountain bighorn sheep are often seen. The community of Riggins benefits from river-related recreation upstream and downstream of the Little Salmon confluence.

Wildlife and outdoor enthusiasts, hunters, photographers, and the general public value the opportunity to view and hunt bighorn sheep. Although there are no specific estimates for bighorn sheep, consumptive and non-consumptive wildlife activities are an important contributor to the economy in Idaho (IDFG 2010). Estimates for annual hunting and wildlife viewing participation in Idaho were 187,000 and 754,000 individuals in 2006 and resulted in gross expenditures of \$259.7 million and \$265.4 million, respectively (USFWS 2007). Within the CFO, recreational opportunities depend in part on bighorn sheep for hunting and wildlife viewing. For example, recreationists enjoy opportunities for river-related wildlife viewing on the Main Salmon and Little Salmon River canyons.

\section{Non-market and Social Values}

The value of resource goods traded in a market can be obtained from information on the quantity sold and market price; however, markets do not exist for some resources, such as recreational opportunities and environmental services. Measuring their value is important, since without estimates, these resources may be implicitly undervalued and decisions regarding their use may not accurately reflect their true value to society. Because these recreational and environmental values are not traded in markets, they can be characterized as non-market values.

Non-market values can be broken down into two categories, use and non-use values. The use value of a non-market good is the value to society from the direct use of the asset; within the vicinity of the planning area, this occurs through activities such as recreational fishing, hunting, and bird watching. The use of non-market goods often requires consumption of associated market goods, such as lodging, gas, and equipment. 
Non-use values of a non-market good reflect the value of an asset beyond any use. These can be described as existence, option, and bequest values. Existence value is the amount society is willing to pay to guarantee that an asset simply exists. An existence value of BLM land within the planning area might be the value of knowing that viable populations of bighorn sheep exist on BLM land. Other non-use values are thought to originate in society's willingness to pay to preserve the option for future use; these non-use values are referred to as option and bequest values. Option values exist for something that has not yet been discovered, such as the future value of a plant as medicine, while bequest values apply to the value of satisfaction from preserving for future generations. In this case, examples include continued existence of future viable bighorn sheep populations or preserving the viability of future grazing traditions.

Non-market use and non-use values can be distinguished by the methods used to estimate them. Use values are often estimated using revealed preference methods or stated preference methods (willingness to pay) while non-use values can only be estimated using hypothetical methods. While use and non-use values exist for the planning area, evaluation is not always feasible during the planning process. However, this does not preclude their consideration in the planning process.

The sale and price of resident and non-resident bighorn sheep tags, including special auction and lottery tags (tags sold by authorized nonprofit organizations to enhance revenue that may be generated), can be attributed directly to bighorn sheep hunting opportunities and thus represent a portion of value attributable to bighorn sheep hunting opportunities. Bighorn sheep tag sales for the 2009 season included 85 controlled hunt permits/tags, 1 auction tag, and 1 lottery tag. Resident tags sell for $\$ 166.75$ and non-resident tags for $\$ 2,101.75$. Eight non-resident and 77 resident tags were allocated in 2009. The auction tag sold for $\$ 120,000$ in 2009 and has averaged $\$ 82,450$ per year over the past 10 years. It should be noted that non-market values associated with hunting are not considered. The IDFG cites information in a 2010 report from a Wyoming willingness to pay study (O'Laughlin and Cook 2010), which estimated that one typical bighorn sheep unit with five tags was worth $\$ 482,100$ in 2008 dollars (IDFG 2010). Using the O'Laughlin and Cook estimate and scaling up to include all bighorn sheep hunting tags in Idaho indicates the non-market economic value of tags statewide was more than $\$ 40$ million dollars in 2009. Non-market values associated with other bighorn sheep-related recreation opportunities are not available; however, they do exist and are discussed qualitatively here and in other parts of the SEIS. Approximately 750,000 people spent 263 million dollars while participating in wildlife viewing in Idaho in 2006 (IDFG 2010). Bighorn sheep values held by area tribes can also be characterized as non-market values (see Section 3.3.2 of this SEIS).

Sheep grazing on the CFO not only plays an important economic role, it also plays an important social role, as area residents identify with the tradition, land use, and history of livestock operations. A community characteristic of note is the intimate culture that surrounds the sheep industry attributable to shared values such as hard work, tradition, and a love for the animals and the land. These traditions are emphasized and cultivated in area events such as county fairs, where 4-H and Future Farmers of America programs contribute to youth education and a sense of community identity. In Cornelius Brosnan's History of the State of Idaho, he states that, "Idaho has become one of the greatest wool-producing States, but has long been noted for its mutton" (Brosnan 1918). Given these cultural and social connections, connections to quality of life related to sheep grazing in the affected area are examined under the alternatives. 
As noted above, non-market and social values are not valued monetarily but rather discussed qualitatively. Not having monetary value assigned to these values does not lessen their importance in the decision-making process. Helpful inferences can still be made from the probability of herd extirpation and acres of protected bighorn sheep habitat available for domestic sheep grazing under the alternatives. These two factors allow the determination of how the alternatives potentially degrade, maintain, or enhance non-market values associated with affected bighorn sheep.

\section{Economic Aspects of Livestock Grazing}

The area affected by domestic sheep grazing use of CFO allotments includes the portions of the intermingled public and privately owned lands in Idaho and Adams counties, and extends to operations in Washington County and the Southwest Agricultural District in Idaho.

Since Cornelius Brosnan's 1918 statement regarding Idaho's notable stature as "one of the greatest wool-producing States," sheep and lamb inventory within the state has declined. According to the 2011 Idaho Agricultural Statistics, sheep and lamb inventory was 235,000 head at the end of 2011; however, this figure is up 25,000 from the record low of 210,000 a year earlier (the recorded high is 2,470,000 in 1920). Gross income from sheep and lamb production was $\$ 23,256,000$ in 2010 . The total number of sheep and lambs marketed was 178,000 , yielding an average price per animal sold of $\$ 130.65$. The value of wool production in Idaho is estimated at $\$ 2,444,000$ in 2010 (see Table 3-7) (Idaho State Department of Agriculture. 2011).

\begin{tabular}{|l|c|c|}
\hline \multicolumn{2}{|c|}{ Table 3-7: } & Sheep and Lamb Inventory and Estimated Annual Forage Requirement \\
\hline \multicolumn{1}{|c|}{ Region } & $\begin{array}{c}\text { Sheep/Lambs } \\
\text { (number of animals) }\end{array}$ & $\begin{array}{c}\text { Annual Forage Requirement } \\
\text { (AUMs) }\end{array}$ \\
\hline Adams County & 875 & 2,100 \\
\hline Idaho County & 2,500 & 6,000 \\
\hline Counties Total & $\mathbf{3 , 3 7 5}$ & $\mathbf{8 , 1 0 0}$ \\
\hline Idaho Total & $\mathbf{2 3 5 , 0 0 0}$ & $\mathbf{5 6 4 , 0 0 0}$ \\
\hline
\end{tabular}

According to state data, on January 1, 2012, there were 2,500 sheep and lambs in Idaho County, but no data was reported for Adams County. Long-term state data for Adams County indicate that an average of 875 sheep and lambs has existed annually from 1986 to 2012 (USDA 2012).

Due to an inability to project actual use as it relates to drought, financial limitations on operators, and market conditions, the examination of current contributions from $\mathrm{CFO}$ allotments examines the allocations for livestock grazing rather than actual use. Therefore, contributions represent the maximum possible contributions from $\mathrm{CFO}$ allotments if all allocated grazing were to occur on allotments.

The total amount of forage currently leased on the four allotments is 896 AUMs. Forage needed to accommodate annual average inventory in Adams County and 2012 inventory in Idaho County is estimated at 8,100 AUMs. Therefore, forage provided by the four allotments affected account for approximately 11 percent of the forage needed for current sheep inventory in Adams and Idaho counties. 
While not the entire source of forage used by the lessees of the four allotments, forage provided by the CFO provides an important source of forage that complements additional sources during other parts of the year. Estimating the contribution of livestock grazing on the impact area using only BLM AUMs may underestimate the actual importance of the BLM as a forage resource, if BLM AUMs are part of an overall grazing system in which a change in BLM grazing affects the optimal use of other non-BLM' forage resources. A previous study by. Alevy and others (2007) in Elko County, Nevada estimated that one public land AUM supports 2.21 AUMs at the ranch level. Therefore, the 896 AUMs supported by the four allotments may support a total of 1,980 AUMs on BLM and other sources of forage. Thus, total forage potentially provided from a ranch production perspective could account for as much as 24.4 percent of the forage needed for sheep inventory in Adams and Idaho counties.

Sheep industry impacts would extend to allotments on the Payette National Forest in Washington County and industries in southwestern Idaho counties, and are included in this analysis because of regional connections unique to the sheep industry and its social role as area residents identify with the tradition, land use, and history of livestock operations. Recent decisions issued by the Payette National Forest not only affect the sheep industry in the same region as the subject BLM allotments, but also directly affect the same companies that hold leases on the BLM allotments. 
This page intentionally left blank. 
This page intentionally left blank. 


\section{CHAPTER 4 - ENVIRONMENTAL CONSEQUENCES}

\subsection{INTRODUCTION}

Chapter 4 supplements the analysis from the 2008 Cottonwood PRMP/FEIS, and presents the direct, indirect, and cumulative impacts likely to occur with the implementation of each of the alternatives described in Chapter 2. Direct impacts are caused by an action or implementation of an alternative and occur at the same time and place. Indirect impacts also result from implementing an action or alternative, but usually occur at a later time or are removed in distance (40 CFR 1502.16). Cumulative impacts are the incremental effects of the proposed action when added to other past, present, and reasonably foreseeable actions, regardless of who carries out the action (40 CFR 1508.7).

The baseline used for analysis is the existing conditions or situation of the resources as described in Chapter 3. The information presented in this section presents an analysis of the environmental consequences of each alternative on:

- Bighorn Sheep (Section 4.2)

- Native American Tribal Interests and Treaty Rights (Section 4.3)

- Livestock Grazing, and Social and Economic Conditions (Section 4.4)

Each resource analysis section begins with an overview, followed by a subsection for the method of analysis, and then by a description of the direct, indirect, and cumulative effects of each alternative.

\subsubsection{Analytical Assumptions}

As stated in Section 1.4, none of the alternatives for this RMP amendment would authorize livestock grazing. Although the area, season of use, and AUMS authorized for livestock grazing must be in compliance with the RMP, including the allocations and constraints that result from this amendment, the actual authorization decision would be determined through site-specific analysis for grazing leases for each allotment. In order to analyze the effects of the alternatives, the BLM had to make the following assumptions regarding future authorizations:

- For allotments where domestic sheep grazing is prohibited, the BLM assumes that a qualified applicant will apply for authorization to graze cattle; and that the BLM will subsequently conduct a site-specific analysis and issue a grazing lease. In actuality, should an applicant apply for such a lease, the BLM would process the lease in accordance with the USDI-BLM Grazing Regulations (43 CFR part 4100) and conduct a site specific analysis of the applicants proposal before deciding whether or not to issue the lease. If the ROD for this SEIS prohibits domestic sheep grazing on the Partridge Creek and/or Hard Creek allotments, the BLM anticipates that it will likely receive an application for grazing cattle soon after publishing the ROD, as there are already livestock operators grazing cattle in or around these allotments. There are currently no cattle operations in the vicinity of Marshal Mountain or Big Creek allotments. So it is less certain whether the BLM would receive applications for these. 
- For allotments and AUMS that are available for domestic sheep grazing, the BLM assumes that these will be used for this purpose in accordance with the terms, conditions, and season of use specified in the current or the most recent grazing leases, with any additional requirements resulting from the RMP amendment applied. Although domestic sheep grazing is not currently occurring on any of the subject allotments, the BLM assumes that use will resume unless prohibited.

- For any of the four allotments where domestic sheep are allowed to grazed, the BLM would develop a separation response plan for bighorn sheep and domestic sheep and require the livestock operator to use BMPs to minimize potential contact (Appendix C). The response plan would define the process, protocols, and timelines for short-term or emergency management actions when specific actions are needed to minimize risk of comingling and contact between bighorn sheep and domestic sheep. The BMPs would be determined at the time of lease renewal and would be specified as stipulations on the lease. Section 4.2.2.5 provides additional information and analysis regarding BMPs which would be stipulated as a term and condition of the grazing lease.

For the cumulative effects analysis, the BLM made the following assumptions regarding uncertainties related to domestic sheep and goat grazing on USFS and private lands in the analysis area:

- The USFS Allison-Berg Allotment (see Map 9 in Appendix D), recently closed by the Nez Perce National Forest pending further study, will remain closed indefinitely. While the USFS has not yet determined the permanent status of this allotment, the BLM made this assumption based on similarity of the situation to that of USFS allotments closed by the Payette Forest Plan ROD. The Allison-Berg Allotment overlaps with the Main Salmon/South Fork CHHR and has a high risk of interspecies contact and disease transmission.

- Idaho Department of Lands domestic sheep grazing allotments will continue to be authorized within the analysis area. There is no indication the Idaho Department of Lands has plans to change their current authorizations.

- Domestic sheep and goat grazing on private land that has been reported to, or observed by, the BLM within the past 5 years will continue in the future. The BLM is not aware of any intentions of private land owners to not graze domestic sheep or goats on these lands in the future.

\subsection{BIGHORN SHEEP}

This section supplements the analysis from the 2008 PRMP/FEIS for wildlife and their habitat resources, and focuses on the effects of alternatives on Rocky Mountain bighorn sheep.

\subsubsection{Overview}

This analysis focuses on local bighorn sheep populations (herds) and habitat that occur within or near the four subject allotments, and includes the Hells Canyon and Salmon River 
metapopulations. Analysis primarily addresses the risk of contact from a bighorn sheep intersecting a domestic sheep allotment and this analysis does not quantify the risk of interspecies disease transmission and population persistence. These populations have varying levels of interconnectivity that provide a mechanism for the spread of disease (Cassirer et al 2013). Only portions of the two different metapopulations occur within the vicinity of the domestic sheep allotments and analysis area (see Map 1 in Appendix D). Traditional population analyses are usually conducted within the context of isolated populations (Hanski 1998); however, a population effects and persistence analysis restricted to bighorn sheep effects resulting from BLM domestic sheep allotments occurring in the analysis area is meaningless unless the dynamics of the metapopulation are also considered; this includes the interconnectivity between local populations and bighorn sheep forays. Consequently, population effects discussions and analysis will need to extend beyond the borders of BLM domestic sheep allotments because of the potential of bighorn sheep coming into contact with domestic sheep and the potential for disease transmission to local populations occurring within the two metapopulations. The BLM acknowledges that domestic sheep may stray from allotments, use areas during unauthorized periods, and potentially come into contact with bighorn sheep, thus resulting in disease transmission.

Population persistence is generally expressed using two components: the number of individuals and persistence of that population over time. For example, Thompson (1991) describes population persistence as 99 percent of the population persisting for 1,000 years or 95 percent persisting for 100 years. Singer and Gudorf (1999) found no absolute minimum viable number for bighorn sheep, but suggest a minimum population size of 100 individuals if disease is not a factor and 300 individuals to buffer against the loss of genetic diversity if severe or moderate outbreaks of disease affecting many animals were to occur. Singer and others (2001) also found a strong correlation of population persistence with larger habitat patch sizes, greater distances from domestic sheep, higher population growth rates, greater home-range sizes, larger population sizes, and migratory movements. Larger populations (more than 250 animals) were more likely to recover following an outbreak of disease that affects many animals, but habitat patch size was the primary correlate of both population performance and persistence (Singer et al. 2001).

Basic components of habitat include space, food, shelter, and water. The focus of this analysis involves the space component of habitat in regard to two species that cannot share the same space due to potential disease transmission.

\subsubsection{Methods of Analysis}

The BLM used outputs derived from the three models previously described (source habitats, CHHR, and risk of contact) to compare alternatives with respect to the risk of contact between domestic sheep and bighorn sheep. Estimates for potential bighorn sheep disease outbreaks were based on modeled estimates of bighorn sheep intersecting a domestic sheep allotment. The analysis did not include any specific disease or population modeling for herd persistence. Disease and population modeling conducted for the Payette SEIS was reviewed and compared with analysis that was completed by the BLM. The BLM also recognized the additional potential for contact and disease transmission resulting from straying domestic sheep. 
Refer to Section 3.2.2.5 and the following section, Contact Rates Relative to Disease Outbreaks and Bighorn Sheep Population Persistence and Analysis Assumptions, regarding assumptions used for bighorn sheep contact with an allotment and disease outbreak $(0.25$ - one in four contacts results in disease outbreak) and average disease outbreak periodicity (50 years). Although we still lack empirical data to make recommendation on the periodicity of outbreaks, and the effects on bighorn sheep, this is a good threshold to use to ensure population persistence until better data is available (USFS 2013b).

\subsubsection{Source Habitat}

Winter and summer source habitats are important use areas for bighorn sheep; each of the four BLM grazing allotments has such habitats within their boundaries (see Section 0 and Table 3-2). For this analysis, the BLM identified summer and winter source habitats that would be available for (i.e., unaffected by) domestic sheep grazing under each alternative.

Generally, the higher number of acres of bighorn sheep source habitat that an alternative identifies as available for domestic sheep grazing, the more likely that alternative will result in potential interspecies contact. The configuration of source habitats, bighorn sheep use of these habitats, and the geographical proximity of bighorn sheep to domestic sheep allotments are significant factors in evaluating the potential for contact and disease transmission. Consequently, it has been inferred that overlap of source habitats within domestic sheep allotments and overlap with or close proximity to CHHRs will result in increased potential for contact between species. Increased numbers of contacts will likely increase the potential for disease transmission.

Both summer (May-October) and winter (November-April) bighorn sheep source habitats were evaluated. However, the focus was primarily on summer source habitats since domestic sheep are mostly present on or near BLM domestic sheep allotments and near bighorn sheep source habitats during this period. The exception was the BLM Partridge Creek allotment, which also contains modeled winter source habitat because domestic sheep season of use overlaps with bighorn sheep winter source habitat periods.

The source habitat model was used to estimate the amount of bighorn sheep summer and winter source habitat that overlaps with areas allocated for domestic sheep grazing for each alternative. The juxtaposition and distances between bighorn sheep summer and winter source habitats, CHHR, and allocated rangelands for domestic sheep are important attributes that influence the probability of contact between the species.

\subsubsection{Core Herd Home Range and Risk of Contact}

Allotment overlap with CHHRs or distances from CHHR are relevant in regard to the probability of contact. The closer an allotment that is available for domestic sheep grazing is to a CHHR, the greater the potential for contact and disease transmission. CHHRs that overlap with an allotment during periods of domestic sheep grazing are predicted to have potential for one or more interspecies contacts per year.

The risk of contact model (CHHR and foray analyses) is perhaps the most critical aspect of the analysis since the consequences of even low levels of interspecies contacts are potentially severe 
for bighorn sheep. Because the model is based on a large telemetry data set and corroborated with source habitat, it is considered a reliable proxy for how the Hells Canyon and Salmon River metapopulations utilize the landscapes, and can be used to determine the likelihood that bighorn sheep will transect domestic sheep allotments. If a bighorn sheep transects or comes in contact with a domestic sheep allotment boundary it is considered a contact with domestic sheep.

\subsubsection{Contact Rates Relative to Disease Outbreaks and Local Population Persistence}

The lower the estimated number of contacts per year, the more likely a bighorn sheep local population will persist. The risk of contact model (USFS 2013) provides the predicted annual rates of contact between bighorn sheep and allotments. Increased rates of interspecies contact is correlated with higher potential for respiratory disease outbreaks. Until better data is available, the threshold assumption for population persistence is that the combined ram and ewe bighorn sheep contact rate between domestic sheep allotments and local populations would be 0.08 annual contacts or less. This threshold uses the assumed probability of a contact between allotments and a local population resulting in an interspecies disease transmission and outbreak event of one in four $(0.25)$, with an average disease outbreak period of one in 50 years.

As described in Ch3 (see 3.2.2.4), population recovery is unlikely should a bighorn population suffer a disease outbreak more frequently than once every 50 years. Alternatives were compared in regard to predicted potential for disease outbreak and population persistence from BLM domestic sheep grazing. If predicted disease outbreaks occurred at intervals of one or more times every one or two decades, the population would have a low probability of persistence. If predicted disease outbreaks occurred at intervals of one time every three to five decades, the population would have a moderate probability of persistence. If predicted disease outbreak were to occur at a rate of less than once every five decades or more, the population would have a high probability of persistence. As stated previously, this analysis will not include any herd specific disease or population modeling from the various alternatives. However, analysis was conducted regarding bighorn sheep intersecting an allotment and used to infer potential for interspecies contact and disease transmission.

No specific local population disease modeling was conducted. Prediction of population persistence based on probability of a bighorn sheep intersecting and allotment and predicted disease outbreak includes uncertainties and variables. Disease modeling is complex and the disease model requires consideration of a number of variables, including demographic characteristics of bighorn sheep herds, disease transmission rates resulting from contacts between domestic sheep and bighorn sheep, disease transmission rates resulting from infected bighorn sheep contacting uninfected bighorn sheep, lethality of the diseases, and time of recovery in infected bighorn sheep herds. Some of these variables have a high degree of uncertainty.

The results of predicted local population persistence should be viewed as a means of comparing the relative impacts of alternatives, not as hard and fast values. Results of the analysis support our current understanding of these bighorn sheep populations, and outputs can be explained based on the understanding of contacts and disease outbreaks resulting from contacts. 


\subsubsection{Straying Domestic Sheep}

The BLM recognizes that straying domestic sheep from sheep bands on grazing allotments or while trailing would increase potential contact with and disease transmission to bighorn sheep. However, due to the number of unpredictable variables, there is no means by which to quantify this additional potential in relation to the alternatives. Overall, the closer an allotment available for domestic sheep grazing is to a local population CHHR, it is expected that such would also have higher potential for straying, resulting in interspecies contact. Consequently, alternatives that have higher predicted annual interspecies contacts are also at higher risks for domestic sheep straying and contact with bighorn sheep.

As described in Section 3.2.2.5, bighorn sheep and domestic sheep have a gregarious behavior which increases the potential for interspecies contact and disease transmission. The Partridge Creek allotment is the only allotment that, if available for domestic sheep use, would have a season of use for domestic sheep that includes the rut or breeding period for bighorn sheep and domestic sheep and overlaps with CHHR. Allotments that only have grazing seasons during the summer are also at risk from straying domestic sheep during the breeding period, because these unattended domestic sheep may stay on allotments for longer time periods which potentially may extend into breeding periods. Unattended straying domestic sheep may wander into areas occupied by bighorn which also increases potential for interspecies contact during non-breeding and breeding periods.

\subsubsection{Best Management Practices}

No known studies, research, or peer reviewed literature has documented the effectiveness of BMPs from preventing contact and disease transmission when domestic sheep or goats graze within or adjacent to occupied bighorn sheep habitats. Effective separation between bighorn sheep and domestic sheep and goats, which minimizes the potential for contact and disease transmission, has been identified as the key management strategy for conservation of bighorn sheep (Wild Sheep Working Group 2012). Literature review (Wehausen et al. 2011) and experimental evidence (Lawrence et al. 2010) support the goal that domestic sheep or goats should not concurrently occupy areas where conservation of bighorn sheep is a clearly stated management goal (Wild Sheep Working Group 2012). Consequently, the focus of analysis conducted for this SEIS was on effective separation (i.e., spatial and temporal) to minimize potential for contact and disease transmission. Following is a brief summary and discussion regarding implementation and effectiveness of BMPs within or adjacent to habitats occupied by bighorn sheep.

Varying levels of effectiveness may be a applied to BMPs that have a large buffer between active domestic sheep allotments and occupied bighorn sheep habitats, and such a buffer minimizes potential for disease transmission. Such allotments would also have to occur in open, gentle, non-bighorn sheep habitat where domestic sheep can be easily controlled and monitored and a large buffer exists between the two species (Schommer 2009); which generally is not occurring for three analysis allotments (Partridge Creek, Marshall Mountain, and Hard Creek Allotments) being assessed in this SEIS. The typical terrain and habitats found on these three domestic sheep allotments are areas that are very steep and rugged and interspersed with a mixture of forest, shrub, dense vegetation, and grassland areas. Overall, the Big Creek Allotment has the most 
moderately sloped terrain and open habitats compared to the other allotments, which have steep and rugged terrain and a variety of habitats that would reduce potential for effective implementation and effectiveness of BMPs.

Control and monitoring of domestic sheep within the topography and habitats typically found in three of the allotments in this SEIS would be very difficult; and monitoring forays of bighorn sheep would be even more difficult, particularly when the majority of bighorn sheep do not have radio collars. Another consideration regarding effectiveness of BMPs is the social nature of domestic sheep and goats and bighorn sheep; these animals may be "attracted to each other," which would further reduce effectiveness of BMPs in a rangeland situation that is not completely controlled and the majority of animals are not monitored (e.g., radio collared or visual observation) during the entire day.

Schommer (2009) completed a position statement regarding the effectiveness of a large number of BMPs that have been used to reduce contact between bighorn sheep and domestic sheep and goats. Following is a list of BMPs that were evaluated by Schommer (2009)

- guard dogs

- propane guns (scare bighorn sheep)

- trucking of sheep

- bedding of sheep in a tight controlled area

- counting of sheep to document straying; improved herder communication

- bighorn sheep monitoring

- removal of sick domestic sheep

- search and removal for stray domestic sheep

In summary, Schommer (2009) identified varying levels of concern regarding the effectiveness of the above BMPs in providing separation particularly when such BMPs would be best implemented when domestic sheep allotments occurred in open, gentle, non-bighorn sheep habitat where domestic sheep can be easily controlled and monitored and a large buffer exists between the species. The previous conditions do not apply to three of the allotments under consideration for this SEIS. Other BMPs not listed above that have been utilized in the past regarding domestic sheep grazing in proximity to bighorn sheep habitats included increased number of herders, increased number of herd dogs, removal of bighorn sheep when in proximity to domestic sheep (e.g., lethal removal, capture and relocation, hazing), fencing or confinement of domestic sheep and goats, removal of domestic sheep from range allotments during breeding season, and others. Overall, these BMPs would also have same level of concerns for effectiveness as identified above. An exception to the above BMPs would be removal of domestic sheep from allotments during breeding season, which would provide acceptable spatial and temporal separation; however, associated contact risks would still occur during non-breeding periods.

In summary, the effectiveness of BMPs in providing adequate separation has not been verified by studies, research, or peer-reviewed literature when domestic sheep or goat grazing occurs in proximity to occupied bighorn sheep habitats. However, stipulating BMPs as terms and conditions for the authorization of domestic sheep grazing will be expected to have varying 
levels of effectiveness that is primarily dependent on proper implementation, terrain, vegetation, and distances from occupied bighorn sheep habitats.

\subsubsection{Effects of Alternatives}

\subsubsection{Effects from Alternative A}

Under Alternative A, the No Action alternative, all four allotments, totaling 19,405 acres, would be available for domestic sheep grazing. Thus all bighorn sheep summer or winter source habitats and CHHRs that occur within the allotments would be available for domestic sheep grazing (Table 4-1).

Table 4-1: Habitats and Core Herd Home Range Available for Domestic Sheep Grazing under Alternative A

\begin{tabular}{|c|c|c|c|}
\hline \multicolumn{2}{|c|}{ Source Habitat Available (acres) } & \multicolumn{2}{c|}{ CHHR Available (acres) } \\
\hline Summer & Winter & Summer & Winter \\
\hline 7,015 & 4,502 & 8,005 & 8,008 \\
\hline
\end{tabular}

Because of allotment overlap with CHHRs or close proximity to CHHRs, this alternative has the highest likelihood of contact between bighorn sheep and domestic sheep allotments. Increased bighorn sheep contacts with an allotment will result in potential higher number of contacts between bighorn sheep and domestic sheep. The majority of the predicted bighorn sheep contact with domestic sheep allotments would occur with the Main Salmon/South Fork local population and the Little Salmon area of concern because overlap with CHHRs exists for these populations, resulting in a low estimated probability of population persistence under this alternative (Table 4-1).

The local bighorn sheep populations in Hells Canyon range from 5.98 miles to 17.44 (Table 4-2) miles from allotments that are available for domestic sheep grazing, resulting in the lowest annual predicted interspecies contacts, and thus a high probability of population persistence, under this alternative.

\begin{tabular}{|l|c|c|c|}
\hline \multicolumn{1}{|c|}{ Table 4-2: } & $\begin{array}{c}\text { Mistance (mi) from } \\
\text { Nearest Domestic Sheep } \\
\text { Allotment }\end{array}$ & $\begin{array}{c}\text { Predicted Allotment } \\
\text { Contacts/Year }\end{array}$ & $\begin{array}{c}\text { Probability of } \\
\text { Population Persistence }\end{array}$ \\
\hline Main Salmon/South Fork & 0.0 & $1.0+$ & Low \\
\hline Little Salmon & 0.0 & $1.0+$ & Low \\
\hline Upper Hells Canyon & 10.23 & 0.0023 & High \\
\hline Myers & 5.98 & 0.0024 & High \\
\hline Muir & 15.7 & 0.0051 & High \\
\hline Big Canyon & 17.44 & 0.0018 & Total = 2.0116+ \\
\hline \multicolumn{4}{|l|}{$\begin{array}{c}\text { Hredieted bighorn sheep contacts with an allotment would be equal to or greater than value shown beeause allotments that } \\
\text { overlap with CHHR may have one or more predieted annual contacts per year. }\end{array}$} \\
\hline
\end{tabular}


In addition, straying of domestic sheep may occur under this alternative, adding an additional risk of contact between the species as well as disease transmission and outbreak; potentially lowering the probability of population persistence. Herding domestic sheep in steep and rugged terrain with forest/shrub/grassland habitats increases the potential for straying of domestic sheep. Highest potential for straying and interspecies contact would occur from domestic sheep grazing in the Partridge Creek allotment because of overlap with Main Salmon/South Fork CHHR, followed by Hard Creek allotment overlap with Little Salmon area of concern, and close proximity (1.19 miles) of Marshall Mountain allotment to Main Salmon/South Fork CHHR.

Alternative A is rated sixth (most) in effects to bighorn sheep because it has the highest amount of bighorn sheep source habitats and CHHRs available for domestic sheep grazing, highest predicted bighorn sheep contacts with domestic sheep allotments and increased potential for interspecies contact, and a low estimated probability of persistence for one local population (Main Salmon/South Fork) and one area of concern (Little Salmon).

\subsubsection{Effects from Alternative B}

Under Alternative B, the BLM preferred alternative, 439 acres in the Big Creek Allotment would be available for domestic sheep grazing. This would include only 1 acre of summer source habitat, no winter source habitat, and no CHHR (Table 4-3).

Table 4-3: $\quad$ Habitats and Core Herd Home Range Available for Domestic Sheep Grazing under Alternative B

\begin{tabular}{|c|c|c|c|}
\hline \multicolumn{2}{|c|}{ Source Habitat Available (acres) } & \multicolumn{2}{c|}{ CHHR Available (acres) } \\
\hline Summer & Winter & Summer & Winter \\
\hline 1 & 0 & 0 & 0 \\
\hline
\end{tabular}

A very low level of interspecies contact is predicted for the Little Salmon River area of concern, and no contacts are predicted for the Main Salmon/South Fork and Hells Canyon local populations (Table 4-4). The nearest area available for domestic sheep grazing (Big Creek Allotment) is 12.96 miles away from the Little Salmon area of concern and 31.8 miles away from the Main Salmon/South Fork local population CHHR. The Hells Canyon local populations range from 26.14 miles to 44.23 miles from the nearest area available for domestic sheep grazing. Considering only BLM attributed domestic sheep grazing effects, population persistence and desired sustaining trends is predicted to be high for Main Salmon/South Fork, Hells Canyon local populations, and Little Salmon area of concern. The Big Creek allotment primarily consists of habitat that does meet criteria for source habitat and only has one acre of summer source habitat. Consequently bighorn sheep would likely prefer other areas providing more desirable habitats.

Table 4-4: $\quad$ Model Results and Predicted Effects on Individual Herds from Alternative B

\begin{tabular}{|l|c|c|c|}
\hline \multicolumn{1}{|c|}{ Herd/CHHR } & $\begin{array}{c}\text { Distance (mi) from } \\
\text { Nearest Domestic Sheep } \\
\text { Allotment }\end{array}$ & $\begin{array}{c}\text { Predicted Allotment } \\
\text { Contacts/Year }\end{array}$ & $\begin{array}{c}\text { Probability of } \\
\text { Population Persistence }\end{array}$ \\
\hline Main Salmon/South Fork & 31.8 & 0.0000 & High \\
\hline Little Salmon & 12.96 & 0.00002 & High \\
\hline
\end{tabular}




\begin{tabular}{|l|c|c|c|}
\hline Table 4-4: Model Results and Predicted Effects on Individual Herds from Alternative B \\
\hline \multicolumn{1}{|c|}{ Herd/CHHR } & $\begin{array}{c}\text { Distance (mi) from } \\
\text { Nearest Domestic Sheep } \\
\text { Allotment }\end{array}$ & $\begin{array}{c}\text { Predicted Allotment } \\
\text { Contacts/Year }\end{array}$ & $\begin{array}{c}\text { Probability of } \\
\text { Population Persistence }\end{array}$ \\
\hline Upper Hells Canyon & 26.14 & 0.0000 & High \\
\hline Myers & 33.83 & 0.0000 & High \\
\hline Muir & 44.23 & 0.0000 & High \\
\hline Big Canyon & 41.84 & 0.0000 & High \\
\hline & & Total =0.00002 & \\
\hline
\end{tabular}

Although only one allotment would be available for domestic sheep grazing, straying of domestic sheep may occur under this alternative, adding an additional risk of contact between the species, as well as disease transmission and outbreak; possibly lowering the probability of population persistence. The habitats associated with this allotment are relatively moderate sloped with open grass/shrub and interspersed timbered areas, however, potential for straying does exist. However, distances from CHHRs range from 26.14 miles to 44.23 miles and 12.96 miles from the Little Salmon area of concern, which would reduce the risk for straying domestic sheep. These interspecies separation buffers are adequate for reducing risk of contact and providing for local population persistence within the analysis area.

This alternative would also require that the grazing lease for Big Creek Allotment include the terms and conditions listed in Appendix C. These measures would reduce, but not completely eliminate, the potential for contact.

Overall, this alternative is rated second (least) for effects on bighorn sheep in regard to source habitats and CHHRs available for domestic sheep grazing, predicted bighorn sheep contact with domestic sheep allotments, and predicted population persistence.

\subsubsection{Effects from Alternative C}

None of the allotments would be available for domestic sheep grazing under Alternative C, Eliminate Domestic Sheep and Goat Grazing; thus there would also be no source habitat or CHHR available for use. There would also be no opportunity for straying of domestic sheep from BLM allotments or trailing associated with movement of domestic sheep from or to BLM allotments. Considering only direct and indirect effects from this alternative, the risk of bighorn sheep intersecting a domestic sheep allotment would be zero and population persistence for the Main Salmon/South Fork and Hells Canyon local populations and Little Salmon area of concern is predicted to be high. Overall, this alternative is rated first for effects (none) to bighorn sheep.

\subsubsection{Effects from Alternative D}

Under Alternative D, Restrict Grazing on Partridge Creek and Hard Creek, 4,651 acres of the Marshall Mountain and Big Creek grazing allotments would be available for domestic sheep grazing. A total of 1,188 acres (Table 4-5) of summer source habitat and no winter source habitat would be available for domestic sheep grazing. No CHHR would be available for domestic sheep grazing since neither allotment overlaps with CHHR. 
Table 4-5: Habitats and Core Herd Home Range Available for Domestic Sheep Grazing under Alternative D

\begin{tabular}{|c|c|c|c|}
\multicolumn{2}{|c|}{ Source Habitat Available (acres) } & \multicolumn{2}{c|}{ CHHR Available (acres) } \\
\hline Summer & Winter & Summer & Winter \\
\hline 1,188 & 0 & 0 & 0 \\
\hline
\end{tabular}

A relatively high level of contact is predicted for the Main Salmon/South Fork local population due to the close proximity (1.19 miles) of the Marshall Mountain Allotment to CHHR; however, because the Marshall Mountain Allotment has a season of use that is only one month long, the predicted contact potential was lower. A very low level of interspecies contact is predicted for the Little Salmon River area of concern and Hells Canyon local populations (Table 4-6). The nearest area available for domestic sheep grazing (Big Creek Allotment) is 12.96 miles away from the Little Salmon area of concern, while the Hells Canyon local populations range from 20.84 miles to 29.10 miles from the nearest area available for domestic sheep grazing. Considering only direct and indirect effects from this alternative, population persistence and desired sustaining trends is predicted to be low to moderate for the Main Salmon/South Fork local population and high for the Little Salmon area of concern and Hells Canyon local populations.

\begin{tabular}{|l|c|c|c|}
\hline Table 4-6: Model Results and Predicted Effects on Individual Herds from Alternative D \\
\hline \multicolumn{1}{|c|}{ Herd/CHHR } & $\begin{array}{c}\text { Distance (mi) from } \\
\text { Nearest Domestic Sheep } \\
\text { Allotment }\end{array}$ & $\begin{array}{c}\text { Predicted Allotment } \\
\text { Contacts/Year }\end{array}$ & $\begin{array}{c}\text { Probability of } \\
\text { Population Persistence }\end{array}$ \\
\hline Main Salmon/South Fork & 1.19 & 0.0734 & Low-Moderate \\
\hline Little Salmon & 12.96 & 0.00004 & High \\
\hline Upper Hells Canyon & 26.14 & 0.0000 & High \\
\hline Myers & 20.84 & 00.00001 & High \\
\hline Muir & 27.72 & 0.0000 & High \\
\hline Big Canyon & 29.10 & 0.0000 & High \\
\hline
\end{tabular}

In addition, straying of domestic sheep may occur under this alternative, adding an additional risk of contact between the species, potentially leading to disease transmission and outbreak and possibly lowering the probability of population persistence. Herding domestic sheep in steep and rugged terrain with forest/shrub/grassland habitats increases the potential for straying of domestic sheep. Because the Marshall Mountain Allotment is only 1.19 miles from the Main Salmon/South Fork CHHR, there is an increased risk for straying domestic sheep and an increased risk of disease transmission; consequently, an adjusted rating of low-moderate was predicted for this local population. A lesser potential risk would occur from the Big Creek Allotment and straying domestic sheep because the Little Salmon area of concern is the nearest local population and occurs 12.96 miles from the allotment.

Overall, this alternative is rated third (least) for bighorn sheep effects in regard to source habitats and CHHRs not available for domestic sheep grazing, predicted bighorn sheep contact with domestic sheep allotments, and population persistence. 


\subsubsection{Effects from Alternative $E$}

Under Alternative E, Restrict Grazing on Partridge Creek Only, 9,861 acres of the Marshall Mountain, Hard Creek, and Big Creek allotments would be available for domestic sheep grazing, including 5,071 acres of summer source habitat and 2,629 acres of summer CHHR (Little Salmon area of concern) (Table 4-7). Since the Partridge Creek Allotment would not be available, none of the winter source or Main Salmon/South Fork CHHR would be affected.

\begin{tabular}{|c|c|c|}
\hline Table 4-7: Habitats and Core Herd Home Range Available for Domestic Sheep Grazing under \\
Alternative $\mathbf{E}$
\end{tabular}

A relatively high level of bighorn sheep contact with the Marshall Mountain allotment is predicted for the Main Salmon/South Fork local population due to the proximity (1.19 miles) of the allotment to CHHR; however, because the season of use for this allotment is only 1 month long, the predicted contacts were lowered. A high level of bighorn sheep contact with an allotment is also predicted for the Little Salmon area of concern due to an overlap with areas available for domestic sheep grazing within the Hard Creek allotment. A very low level of contact with domestic sheep allotments is predicted from the Hells Canyon local populations, which range from 10.23 to 21.26 miles from the nearest area available for domestic sheep grazing (Table 4-8). Considering only the direct and indirect effects from this alternative, population persistence is predicted to be low to moderate for Main Salmon/South Fork local population, low for the Little Salmon area of concern; and high for the Hells Canyon local populations.

Table 4-8: Model Results and Predicted Effects on Individual Herds from Alternative E

\begin{tabular}{|l|c|c|c|}
\hline \multicolumn{1}{|c|}{ Herd/CHHR } & $\begin{array}{c}\text { Distance (mi) from } \\
\text { Nearest Domestic Sheep } \\
\text { Allotment }\end{array}$ & $\begin{array}{c}\text { Predicted Allotment } \\
\text { Contacts/Year }\end{array}$ & $\begin{array}{c}\text { Probability of } \\
\text { Population Persistence }\end{array}$ \\
\hline Main Salmon/South Fork & 1.19 & 0.0788 & Low-Moderate \\
\hline Little Salmon & 0.0 & $1.0+$ & Low \\
\hline Upper Hells Canyon & 10.23 & 0.0004 & High \\
\hline Myers & 11.28 & 0.0001 & High \\
\hline Muir & 21.26 & 0.000002 & High \\
\hline Big Canyon & 19.14 & 0.00001 & Total = $\mathbf{1 . 0 7 9 3 1 2 +}$ \\
\hline & \multicolumn{3}{|l|}{} \\
\hline $\begin{array}{l}\text { +Predicted bighorn sheep contacts with an allotment would be equal to or greater than value shown because allotments that } \\
\text { overlap with CHHR may have one or more predicted annual contacts per year. }\end{array}$
\end{tabular}

In addition, straying of domestic sheep may occur under Alternative E, adding an additional risk of contact between the species, potentially leading to disease transmission and outbreak and possibly lowering the probability of population persistence. Herding domestic sheep in steep and rugged terrain with forest/shrub/grassland habitats increases the potential for straying of domestic sheep. The Hard Creek allotment overlaps with the Little Salmon area of concern and 
would have the highest risks associated with straying and interspecies contact. Because the Marshall Mountain Allotment is only 1.19 miles from the Main Salmon/South Fork CHHR, there is an increased risk for straying domestic sheep and an increased risk of disease transmission; consequently, an adjusted rating of low-moderate was predicted for this local population. A lesser potential risk would occur from the Big Creek Allotment and straying domestic sheep because the Little Salmon area of concern is the nearest local population and occurs 12.96 miles from the allotment.

Overall, this alternative is rated fifth (least) for effects on bighorn sheep in regard to source habitats and CHHRs not available for domestic sheep grazing, predicted bighorn sheep contact with domestic sheep allotments, and population persistence.

\subsubsection{Effects from Alternative $F$}

Under Alternative F, Restrict Grazing on Partridge Creek and Marshall Mountain, 5,649 acres in the Hard Creek and Big Creek grazing allotments would be available for domestic sheep grazing. This includes a total of 5,649 acres of summer source habitat and 2,629 acres of summer CHHR (Little Salmon area of concern) (Table 4-9). No winter source habitat or winter CHHR would be affected.

Table 4-9: Habitats and Core Herd Home Range Available for Domestic Sheep Grazing under Alternative $\mathrm{F}$

\begin{tabular}{|c|c|c|c|}
\hline \multicolumn{2}{|c|}{ Source Habitat Available (acres) } & \multicolumn{2}{c|}{ CHHR Available (acres) } \\
\hline Summer & Winter & Summer & Winter \\
\hline 5,649 & 0 & 2,629 & 0 \\
\hline
\end{tabular}

A high level of bighorn sheep contact with the Hard Creek allotment is predicted for the Little Salmon area of concern due to an overlap with this allotment and areas available for domestic sheep grazing, but a relatively low level of bighorn sheep and allotment contact is predicted for the Main Salmon/South Fork and Hells Canyon local populations. The Salmon River/South Fork CHHR is 12.15 miles from the nearest area available for domestic sheep grazing. The Hells Canyon CHHRs range from 10.23 miles to 21.26 miles from the nearest area available for domestic sheep grazing (Table 4-10). Considering only the direct and indirect effects from this alternative, population persistence is predicted to be low for the Little Salmon area of concern and high for the Main Salmon/South Fork and Hells Canyon local populations.

\begin{tabular}{|l|c|c|c|}
\hline Table 4-10: Model Results and Predicted Effects on Individual Herds from Alternative F \\
\hline Herd/CHHR & $\begin{array}{c}\text { Distance (mi) from } \\
\text { Nearest Domestic Sheep } \\
\text { Allotment }\end{array}$ & $\begin{array}{c}\text { Predicted Allotment } \\
\text { Contacts/Year }\end{array}$ & $\begin{array}{c}\text { Probability of } \\
\text { Population Persistence }\end{array}$ \\
\hline Main Salmon/South Fork & 12.15 & 0.0054 & High \\
\hline Little Salmon & 0.0 & $1.0+$ & Low \\
\hline Upper Hells Canyon & 10.23 & 0.0004 & High \\
\hline Myers & 11.28 & 0.00009 & High \\
\hline Muir & 21.26 & 0.000002 & High \\
\hline
\end{tabular}


Table 4-10: Model Results and Predicted Effects on Individual Herds from Alternative F

\begin{tabular}{|l|c|c|c|}
\hline Herd/CHHR & $\begin{array}{c}\text { Distance (mi) from } \\
\text { Nearest Domestic Sheep } \\
\text { Allotment }\end{array}$ & $\begin{array}{c}\text { Predicted Allotment } \\
\text { Contacts/Year }\end{array}$ & $\begin{array}{c}\text { Probability of } \\
\text { Population Persistence }\end{array}$ \\
\hline Big Canyon & 19.14 & 0.00001 & High \\
\hline \multicolumn{2}{|c|}{$\begin{array}{c}\text { Total = 1.005902+ } \\
\text { +Predicted bighorn sheep contacts with an allotment would be equal to or greater than value shown beeause allotments that } \\
\text { overlap with CHHR may have one or more predieted annual contacts per year. }\end{array}$} \\
\hline
\end{tabular}

In addition, straying of domestic sheep may occur under this alternative, adding an additional risk of contact between the species, potentially leading to disease transmission and outbreak and possibly lowering the probability of population persistence. Herding domestic sheep in steep and rugged terrain with forest/shrub/grassland habitats increases the potential for straying of domestic sheep. The Hard Creek allotment overlaps with the Little Salmon area of concern and would have the highest risks associated with straying and interspecies contact. A lesser potential risk would occur from the Big Creek Allotment and straying domestic sheep because the Little Salmon area of concern is the nearest local population and occurs 12.96 miles from the allotment.

Overall, this alternative is rated fourth (least) for effects to bighorn sheep in regard to source habitats and CHHRs not available for domestic sheep grazing, predicted bighorn sheep contact with domestic sheep allotments, and population persistence.

\subsubsection{Comparison of Effects from Alternatives}

Table 4-11 compares the acres of source habitat and CHHR that is within the grazing allotments that would be available for domestic sheep grazing under each of the alternatives. The potential for contact between species increases with the amount of habitat and CHHR available for domestic sheep grazing.

Table 4-11: $\quad$ Source Habitat and Core Herd Home Range Available for Domestic Sheep Grazing by Alternative

\begin{tabular}{|l|c|c|c|c|c|c|}
\hline \multicolumn{1}{|c|}{ Habitat/Range } & Alt A & Alt B & Alt C & Alt D & Alt E & Alt F \\
\hline Summer Source Available (acres) & 7,015 & 1 & 0 & 1,188 & 5,071 & 5,649 \\
\hline Winter Source Available (acres) & 4,502 & 0 & 0 & 0 & 0 & 0 \\
\hline Summer CHHR Available (acres) & 8,005 & 0 & 0 & 0 & 2,629 & 2,629 \\
\hline Winter CHHR Available (acres) & 8,008 & 0 & 0 & 0 & 0 & 0 \\
\hline
\end{tabular}

Table 4-12 compares the distance between herd CHHR and BLM allotments available for domestic sheep grazing under each alternative. A shorter distance indicates a higher potential for contact between species. 


\begin{tabular}{|c|c|c|c|c|c|c|}
\hline \multirow[t]{3}{*}{ Table 4-12: } & $\begin{array}{l}\text { tween } \\
\text { zing by }\end{array}$ & $\begin{array}{l}\text { Core } 1 \\
\text { rnative }\end{array}$ & Home Range an & M Lan & ailable & mestic \\
\hline & \multicolumn{6}{|c|}{ Distance between CHHR and Available Allotment (miles) } \\
\hline & Alt A & Alt B & Alt C & Alt D & Alt $\mathrm{E}$ & Alt F \\
\hline Main Salmon/South Fork & 0.0 & 31.8 & None Available & 1.19 & 1.19 & 12.15 \\
\hline Little Salmon & 0.0 & 12.96 & None Available & 12.96 & 0.0 & 0.0 \\
\hline Upper Hells Canyon & 10.23 & 26.14 & None Available & 26.14 & 10.23 & 10.23 \\
\hline Myers & 5.98 & 33.83 & None Available & 20.84 & 11.28 & 11.28 \\
\hline Muir & 15.7 & 44.23 & None Available & 27.72 & 21.26 & 21.26 \\
\hline Big Canyon & 17.44 & 41.84 & None Available & 29.10 & 19.14 & 19.14 \\
\hline Nearest CHHR & 0.0 & 12.96 & $\mathrm{~N} / \mathrm{A}$ & 1.19 & 0.0 & 0.0 \\
\hline
\end{tabular}

Table 4-13 compares the probable contacts per year for each potentially affected herd. Alternative A would have the highest probability of contact (ranked 6), and Alternative C would have the least potential for contact (ranked 1).

\begin{tabular}{|c|c|c|c|c|c|c|}
\hline \multirow[t]{3}{*}{$\begin{array}{l}\text { Compariso } \\
\text { and Domes }\end{array}$} & \multicolumn{6}{|c|}{$\begin{array}{l}\text { Comparison of Alternatives Based on Annual Modeled Contacts between Bighorn Sheep } \\
\text { and Domestic Sheep Allotments }\end{array}$} \\
\hline & \multicolumn{6}{|c|}{ Probable Contacts/Year } \\
\hline & Alt $\mathrm{A}$ & Alt B & Alt C & Alt D & Alt $\mathbf{E}$ & Alt F \\
\hline Main Salmon/South Fork & $1.0+$ & 0.0000 & 0.0000 & 0.0734 & 0.0788 & 0.0054 \\
\hline Little Salmon & $1.0+$ & 0.00002 & 0.0000 & 0.00004 & $1.0+$ & $1.0+$ \\
\hline Upper Hells Canyon $^{2}$ & 0.0023 & 0.0000 & 0.0000 & 0.0000 & 0.0004 & 0.000425 \\
\hline Myers & 0.0024 & 0.0000 & 0.0000 & 0.00001 & 0.0001 & 0.00009 \\
\hline Muir & 0.0051 & 0.0000 & 0.0000 & 0.0000 & 0.000002 & 0.000002 \\
\hline Big Canyon & 0.0018 & 0.0000 & 0.0000 & 0.0000 & 0.00001 & 0.00001 \\
\hline Total Modeled Contacts & $2.0116+$ & 0.00002 & 0.0000 & 0.07345 & $1.079312+$ & $1.005902+$ \\
\hline $\begin{array}{l}\text { Ranking of Alternatives for } \\
\text { Reducing Contacts }\end{array}$ & 6 & 2 & 1 & 3 & 5 & 4 \\
\hline
\end{tabular}

Table 4-14 compares the predicted probability of herd persistence, with Alternative A ranking lowest (6) and Alternative $C$ ranking highest (1). Although the predicted herd persistence identified for Alternative B (2) is the same as those for Alternative C, Alternative B would have a higher potential to affect persistence due to the probability for bighorn sheep contacts with a domestic sheep allotments and inferred potential interspecies contact with the Little Salmon area of concern (see Table 4-13). Similarly, Table 4-14 shows similar herd persistence predictions for alternatives $\mathrm{A}$ and $\mathrm{E}$, but the rankings for these alternatives are based on the probability of bighorn sheep contact with a domestic sheep allotment as shown in Table 4-13. 


\begin{tabular}{|l|c|c|c|c|c|c|}
\hline \multirow{2}{*}{ Table 4-14: } & $\begin{array}{c}\text { Comparison of Alternatives Based on Predicted Probability of Population Persistence and } \\
\text { Desired Sustaining Trends }\end{array}$ \\
\cline { 2 - 8 } & \multicolumn{7}{|c|}{ Predicted Probability of Population Persistence and Desired Sustaining Trends } \\
\cline { 2 - 8 } Herd/Population & A & B & C & D & E & F \\
\hline Main Salmon/South Fork & Low & High & High & Low-Mod & Low-Mod & High \\
\hline Little Salmon & Low & High & High & High & Low & Low \\
\hline Upper Hells Canyon & High & High & High & High & High & High \\
\hline Myers & High & High & High & High & High & High \\
\hline Muir & High & High & High & High & High & High \\
\hline Big Canyon & High & High & High & High & High & High \\
\hline $\begin{array}{l}\text { Ranking of Effects on } \\
\text { Population Persistence } \\
\text { (1=least, 6=most) }\end{array}$ & 6 & 2 & 1 & 3 & 5 & 4 \\
\hline
\end{tabular}

\subsubsection{Cumulative Effects}

Domestic sheep grazing occurs on USFS, state, and private lands (see Map 9 in Appendix D) within the vicinity of the cumulative effects analysis area, which could potentially affect bighorn sheep and their habitat. The cumulative effect analysis focuses on how likely disease transmission is to occur from domestic sheep allotments to bighorn sheep local populations. However, if analysis indicates that a local population is at risk for disease transmission (e.g., low or moderate risk for population persistence); bighorn sheep disease transmission to other bighorn sheep and local populations may occur within the metapopulation.

Domestic sheep grazing on lands not controlled by the BLM can and often does occur within or close proximity to bighorn sheep CHHRs or source habitats. This includes grazing by small farm flocks as well as those who graze domestic sheep as a primary source of income. Goats are also used on private lands for the control of invasive weeds in the lower Salmon River and Snake River drainages. These weed-eating goats may graze private lands periodically as needed by the private land owner. Domestic sheep and goat grazing on private land will be a factor in the risk of disease transmission for bighorn sheep populations within the analysis area, regardless of the amount of domestic sheep grazing authorized on any of the 4 BLM allotments. However, it is important to note that domestic sheep or goat grazing on other federal, state, and private lands contribute to varying levels of potential for interspecies contact and disease transmission. The total effects to the two metapopulations are unknown, since the potential risk of contact from lands other than the BLM domestic sheep allotments is not completely known.

The risk of contact model was run for cumulative effects using the assumptions identified in Section 4.1.1.

Implementation of the Payette FSEIS/ROD (USFS 2010b) resulted in the closure of seven domestic sheep allotments that are adjacent to and in proximity of the BLM Partridge Creek, Marshall Mountain, and Hard Creek allotments (see Map 10 in Appendix D). Table 4-15 presents the estimated cumulative contacts per year modeled under the BLM alternatives, as well as from domestic sheep grazing on state, private, and USFS lands. 
Table 4-15: Modeled Contact Rates between Bighorn Sheep and Domestic Sheep Allotments and Additional Cumulative Effects from Adjacent Land Ownerships

\begin{tabular}{|c|c|c|c|c|c|c|c|c|}
\hline \multirow[b]{3}{*}{ Herd Name } & \multicolumn{8}{|c|}{$\begin{array}{c}\text { Predicted Bighorn Sheep Contacts with Areas Grazed by } \\
\text { Domestic Sheep and Goats/Year }\end{array}$} \\
\hline & \multicolumn{6}{|c|}{ Alternatives } & \multicolumn{2}{|c|}{ Year } \\
\hline & A & B & $\mathrm{C}$ & D & $\mathbf{E}$ & F & $\mathrm{Cl}^{*}$ & $\mathrm{C} 2 *$ \\
\hline $\begin{array}{l}\text { Main Salmon/South } \\
\text { Fork }\end{array}$ & $1.0+$ & 0.0000 & 0.0000 & 0.0734 & 0.0788 & 0.0054 & $1.0+$ & 0.0400 \\
\hline Little Salmon & $1.0+$ & 0.00002 & 0.0000 & 0.00001 & $1.0+$ & $1.0+$ & $1.0+$ & 0.0100 \\
\hline Upper Hells Canyon & 0.0023 & 0.0000 & 0.0000 & 0.0000 & 0.0004 & 0.000425 & 0.0100 & 0.0300 \\
\hline Myers & 0.0024 & 0.0000 & 0.0000 & 0.00001 & 0.0001 & 0.00009 & 0.0100 & 0.0000 \\
\hline Muir & 0.0051 & 0.0000 & 0.0000 & 0.0000 & 0.000002 & 0.000002 & 0.0100 & 0.0000 \\
\hline Big Canyon & 0.0018 & 0.0000 & 0.0000 & 0.0000 & 0.00001 & 0.00001 & 0.0000 & 0.0000 \\
\hline Contacts/Year & $2.0116+$ & 0.00002 & 0.0000 & 0.07345 & $1.079312+$ & $1.005902+$ & 2.0300 & 0.0800 \\
\hline $\begin{array}{l}\text { Cumulative } \\
\text { Contacts/Year } \mathrm{Cl}^{*}\end{array}$ & 4.0416 & $2.03002+$ & 2.0300 & $2.10345+$ & $3.109312+$ & $3.035902+$ & --- & --- \\
\hline $\begin{array}{l}\text { Cumulative } \\
\text { Contacts/Year } \mathrm{C} 2^{*}\end{array}$ & 2.0916 & 0.08002 & 0.0800 & 0.15345 & $1.159312+$ & 1.1158 & --- & --- \\
\hline $\begin{array}{l}\text { Cumulative Contacts/ } \\
\text { Year Total }\end{array}$ & 4.1216 & 2.11004 & 2.1100 & 2.18345 & 3.5785 & $3.115902+$ & --- & --- \\
\hline
\end{tabular}

The implications of these additional contacts, particularly from state and private lands, are substantial; primarily for the Main Salmon/South Fork and Little Salmon area of concern. Applying the same inference regarding disease transmission and population persistence used in the previous analysis, results included a predicted low probability of persistence for the Main Salmon/South Fork local population and Little Salmon area of concern regardless of the BLM alternative considered. Thus, the largest bighorn sheep population (Main Salmon/South Fork), even under the most favorable alternative $(\mathrm{C})$, would likely not persist under this cumulative effects scenario. However, the BLM's Alternatives B, D, E, and F would reduce the potential that domestic sheep grazing on BLM land would contribute to this low probability of persistence, and Alternative $\mathrm{C}$ would eliminate the potential. Under this scenario, the potential exists for straying domestic sheep from non-BLM lands, which would add to the probability for contact, disease transmission, and a lower probability of persistence under all alternatives. Trailing routes are the stock trails that producers use to move domestic sheep onto and off of the Payette National Forest, and BLM and private lands. Trailing routes are treated as linear features in the model and are rated separately, depending on their relationship to CHHRs, bighorn sheep foray routes, and current domestic sheep allotments (where domestic sheep are likely to exist). Trailing routes that intersect bighorn sheep CHHRs have a high probability of contributing to interspecies contacts, and those that intersect bighorn sheep source habitats have the potential for contact and disease transmission.

Trailing sheep can also result in stray domestic sheep that utilize habitats occupied by bighorn sheep outside of the grazing season (e.g., potential contacts on winter source habitats), as some trailing routes are near or on bighorn sheep CHHRs (e.g., Salmon River Road - private trailing). 
Strays from trailing domestic sheep may come into contact with these sheep for prolonged periods, thus threatening herd persistence. BMPs for trailing sheep that address temporal and spatial separation for domestic sheep and bighorn sheep may reduce potential for interspecies contact by designating trailing routes in areas that have minimal or no risk for contact and disease transmission. Other trailing BMPs to minimize potential interspecies contact include short durations of trailing across areas (no lingering or grazing), close herding, extra herders and dogs to reduce strays, monitoring or surveying for bighorn sheep in area, accountability for domestic sheep being trailed (counting), no trailing of sick or injured domestic sheep, and quick search and location of strays.

Under the Payette FSEIS/ROD (USFS 2010b), trailing routes on rangelands identified as suitable for domestic sheep would result in 31 percent of the existing domestic sheep trailing routes being left open. The USFS completed a contact analysis that displayed the risk of contacts with a trailing route area. However, it was determined that because domestic sheep only use these areas for a short time, the results were not significant (USFS 2010b).

\subsection{NATIVE AMERICAN TRIBAL USES}

This section supplements the analysis from the 2008 Cottonwood PRMP/FEIS, specific to addressing how the six alternative livestock grazing management strategies would affect treatyreserved resources, consistent with meeting the BLM's obligations to the Nez Perce Tribe.

\subsubsection{Overview}

This analysis presents the potential direct, indirect, and cumulative impacts of the six alternatives as described in Chapter 2. A change in occurrence or availability of bighorn sheep in the ceded lands is an indicator of an impact to the ability of Nez Perce Tribal members to exercise their treaty rights. Methods of Analysis

As outlined in Section 3.3, the BLM has a trust responsibility to the Nez Perce Tribe to manage bighorn sheep habitat. Objective NA-1.1 of the Cottonwood ROD/RMP states: "Maintain and, where possible, improve natural and cultural resource conditions to enhance opportunities to exercise Native American traditional uses." Bighorn sheep are intertwined into Nez Perce socio-cultural activities, and a change in hunting opportunities changes the ability to practice and maintain cultural traditions. Thus, this analysis on the effects to Tribal treaty hunting rights as they relate to bighorn sheep is tied to the following factors:

- The continued availability of the species over time in harvestable numbers

- The amount of area inhabited by bighorn sheep that Tribal members wish to utilize for their hunts

Grazing of domestic sheep adjacent to known bighorn sheep populations impacts the ability of the bighorn populations to pioneer, explore, expand, or co-mingle with other isolated groups to increase their populations. The result is a reduced area for the Tribes to hunt that may or may not overlay with areas that were historically and/or traditionally important. 
Information regarding the number of bighorn sheep that Tribal members have harvested or wish to harvest is not available. Therefore, this discussion centers on the availability of bighorn sheep habitat and populations over time. The BLM made three assumptions for the Native American Tribal Uses in this analysis:

- That opportunities to hunt bighorn sheep are directly related to population persistence

- The amount of area available to hunt bighorn sheep increases as the amount of source habitat available to bighorn sheep without domestic sheep presence increases

- As the amount of source habitat available to bighorn sheep increases, the opportunity to hunt in areas either traditionally or culturally important to Tribal members also increases

The alternatives to be analyzed vary in the magnitude of risk for contact between bighorn sheep and domestic sheep. This results in varying degrees of subsequent implications for the persistence of bighorn sheep populations over time and their potential distribution. For these reasons, direct, indirect, or cumulative potential effects on treaty resources available to the Nez Perce Tribe could be expected as a result of BLM activities.

\subsubsection{Effects of Alternatives}

\subsubsection{Effects from Alternative A}

Alternative A, the No Action alternative, would result in a high risk of contact between bighorn sheep and domestic sheep as allotments continue to be grazed. Higher modeled bighorn sheep contact with domestic sheep (see Table 4-2) are indicated for two herds. This alternative does not provide for long-term persistence of healthy bighorn sheep populations, with two herds having low probability of population persistence. All acres of source habitat within the allotments (see Table 4-1) would be used for domestic sheep grazing under this alternative; thus, Alternative A would reduce Tribal hunting opportunities and the opportunity to maintain associated traditional socio-cultural values in traditional areas.

\subsubsection{Effects from Alternative B}

Alternative B, the BLM preferred alternative, would provide greater opportunity for Tribal harvest than would alternatives A, D, E, and F, as the outcomes for persistence of bighorn sheep would be more favorable under this alternative. In addition, the probability for contact between species is lower than for alternatives A, D, E, and F (see Table 4-13). There is a high probability of persistence (see Table 4-4) for all bighorn sheep herds under this alternative. The amount of source habitat available to bighorn sheep without the presence of domestic sheep would be the greatest compared to all alternatives, except Alternative C (see Table 4-11). Considering only the direct and indirect effects, opportunities for Tribal hunting and maintaining associated traditional socio-cultural values in traditional areas would be greater under Alternative B compared to all other alternatives, except Alternative C. 


\subsubsection{Effects from Alternative $C$}

Alternative C, Eliminate Domestic Sheep and Goat Grazing, would remove all risk of contact between bighorn and domestic sheep on BLM land, as no domestic sheep grazing would be permitted on the BLM administered allotments, resulting in a high probability of persistence for all bighorn sheep herds. The amount of source habitat available to bighorn sheep without domestic sheep presence is greatest under Alternative C. In the long term, considering only the direct and indirect effects, this alternative would provide the greatest Tribal hunting opportunities and maintaining of associated traditional socio-cultural values in traditional areas when compared to all other alternatives.

\subsubsection{Effects from Alternative D}

Risk of contact would be high for one herd under Alternative D, Restrict Grazing on Partridge Creek and Hard Creek. However, the modeled contact risk is lower than for alternatives A, E, and $\mathrm{F}$ for bighorn sheep populations (see Table 4-13). There is a low probability of persistence (see Table 4-8) for one bighorn sheep herd under Alternative D. This alternative opens up more potential area to bighorn sheep than would alternatives $\mathrm{A}, \mathrm{E}$, and $\mathrm{F}$, but less than alternatives $\mathrm{B}$ and C. Considering only the direct and indirect effects of each alternative, Alternative D would provide more opportunities for Tribal hunting and maintaining associated traditional sociocultural values in traditional areas than would alternatives $\mathrm{A}, \mathrm{E}$, and $\mathrm{F}$, but less than alternatives $\mathrm{B}$ and $\mathrm{C}$.

\subsubsection{Effects from Alternative $\mathrm{E}$}

Risk of contact would be high for two herds under Alternative E, Restrict Grazing on Partridge Creek Only. The modeled contact risk is lower than for Alternative A for bighorn sheep populations, but higher than all other alternatives (Table 4-13). There would be a low probability of persistence (Table 4-8) for two bighorn sheep herds. Alternative E would open up more potential area to bighorn sheep, as the amount of area available for domestic sheep grazing would be less than under Alternative $A$, but there would be less area available for bighorn sheep than alternatives B, C, D, and F. Considering only the direct and indirect effects of each alternative, Alternative $\mathrm{E}$ would provide more opportunities for Tribal hunting and maintaining associated traditional socio-cultural values in traditional areas than Alternative A only.

\subsubsection{Effects from Alternative $F$}

Risk of contact would be high for one herd under Alternative F, Restrict Grazing on Partridge Creek and Marshall Mountain. The modeled contact risk is lower than for alternatives A and E for bighorn sheep populations, but higher than alternatives B, C, and D (Table 4-13). There would be a low probability of persistence (Table 4-10) for one bighorn sheep herd. Alternative F would open up more potential area to bighorn sheep, as the amount of area available for domestic sheep grazing would be less than for Alternative A, but there would be less area available for bighorn sheep than there would for alternatives B, C, D, and E. Considering only the direct and indirect effects of each alternative, Alternative $\mathrm{F}$ would provide more opportunities 
for Tribal hunting and maintaining associated traditional socio-cultural values in traditional areas than alternatives $\mathrm{A}$ and $\mathrm{E}$ only.

\subsubsection{Cumulative Effects}

The area and assumptions used in this cumulative effects analysis are the same as those identified in the cumulative effects analysis for bighorn sheep (see Sections 4.2.4 and 4.1.1).

Table 4-15 displays the estimated cumulative contacts per year in addition to those modeled under the BLM alternatives previously described. As stated in Section 2.4.2, the probability of contact with domestic sheep managed on state and private land is substantial, at double the contact per year for all the alternatives. Even so, some BLM alternatives contribute to a reduction of the overall modeled risk of contact. Under this cumulative scenario, the Little Salmon River local population and the Main Salmon/South Fork herd would not likely persist, regardless of any decision made by the BLM. Tribal treaty hunting opportunities and the maintenance of associated traditional socio-cultural values will be affected by this loss of herd persistence under the cumulative scenario. Fewer numbers of bighorn sheep may also result in a reduced area in which the Tribe can hunt successfully, thus removing opportunities that were historically and/or traditionally important to the Tribe for hunting. Potential reduction in the available bighorn sheep to harvest will affect internal Tribal cultural relationships as well as external Tribal relations with other groups.

\subsection{LIVESTOCK GRAZING, AND SOCIAL AND ECONOMIC CONDITIONS}

This section supplements the analysis from the 2008 Cottonwood PRMP/FEIS for Resource Uses and Livestock Grazing, as well as Social and Economic Conditions. This section is also an update of the effects analysis in the Cottonwood PRMP/FEIS, focusing specifically on the alternatives presented in Chapter 2 of this SEIS.

\subsubsection{Overview}

This section describes the direct, indirect, and cumulative impacts that could result from any of the alternatives proposed for changes to livestock grazing, as well as the effects on social and economic conditions related to the effects from domestic sheep grazing and potential disease transmission to bighorn sheep.

\subsubsection{Methods of Analysis}

\subsubsection{Livestock Grazing}

Any effects of the alternatives would be dependent on whether domestic sheep grazing would be prohibited within any of the four allotments. The method of analysis for livestock grazing focuses on allocation of forage (AUMs), areas open or closed to domestic sheep grazing, and logistical effects on the lessees' livestock operation and use of rangelands on BLM allotments and adjacent areas. Information used includes data from the Rangeland Administration System 
(RAS), grazing case files, and GIS datasets. The analysis is also based on the assumptions identified in Section 4.1.1.

\subsubsection{Social and Economic Conditions}

The analysis of economic effects considers job and labor income effects in an economic impact analysis through input-output modeling. Non-market values, such as the value of recreation experiences and ecological services, by nature are difficult to quantify. Direction provided in the BLM Land Use Planning Handbook - Appendix D, suggests the use of benefit transfer to evaluate the effects of these non-market values. In the absence of quantitative information for other non-market values and social effects, they are discussed qualitatively here and in other parts of this SEIS.

The measures and analysis methods listed in Table 4-16 offer consistent measures for comparing alternatives, but should not be viewed as a complete answer; considering these impacts alongside additional social, ecological, or other non-market values provides a complete comparison of the alternatives.

Table 4-16: Measures and Analysis Methods

\begin{tabular}{|l|l|l|}
\hline \multicolumn{1}{|c|}{ Measures } & \multicolumn{1}{|c|}{ Analysis Method } & \multicolumn{1}{c|}{ Analysis Tool } \\
\hline $\begin{array}{l}\text { Economic Impacts (Jobs and } \\
\text { Labor Income) }\end{array}$ & Input-Output Analysis & IMPLAN, 2010 \\
\hline Non-market and Social Values & Indicators discussed below & Discussion in text \\
\hline Environmental Justice & $\begin{array}{l}\text { Varies based on effects to populations } \\
\text { of interest }\end{array}$ & Discussion in text \\
\hline
\end{tabular}

\section{Employment and Labor Income Impacts}

Economic impacts in terms of employment and labor income are used to evaluate potential direct, indirect, and cumulative effects on the impact area economy. Economic impacts are estimated using an input-output analysis, which is a means of examining relationships within an economy, both between businesses and between businesses and final consumers; it captures all monetary market transactions for consumption in a given time period. The resulting mathematical representation allows an examination of the effect of change (the impact analysis), if any, on economic activities on an entire economy. The input-output modeling tool most commonly used by the USFS and BLM is IMPLAN. The IMPLAN modeling system allows the user to build regional economic models of one or more counties for a particular year. IMPLAN translates changes in final demand for goods and services into resulting changes in economic effects, such as labor income and employment of the affected area's economy. The model for this updated analysis used 2010 IMPLAN data.

The economic impact effects are measured by estimating the direct employment and labor income, both of which directly affect the local economy, from (1) changes in sheep grazing under the alternatives, and (2) potentially affected recreation. Additional indirect and induced multiplier effects (ripple effects) are generated by the direct activities. Together, the direct and multiplier effects comprise the total economic impacts to the local economy. 


\section{Methods Specific to Estimating Sheep Grazing Effects}

Employment and income effects from grazing are assessed using direct, indirect, and induced multipliers developed by the BLM for Idaho (U.S. Department of Interior 2013). The analysis is also based on the assumptions in Section 4.1.1 regarding grazing use.

\section{Methods Specific to Estimating Recreation Effects}

Recreation dependent on potentially affected bighorn sheep herds includes opportunities inside and outside the bighorn sheep analysis area. For example, the Salmon River herd may be affected by management actions under the alternatives, and consequently, hunting and wildlife watching opportunities would be affected inside and outside of that area. As these visitors travel to the area, they spend money on goods and services in the local economy. Since levels of recreation related to bighorn sheep are not known, the total economic impact for every 1,000 visits is estimated and discussed below. The response coefficients for hunting and viewing wildlife provide the economic effect specific to bighorn sheep recreation opportunities in the three-county impact area, thus providing a frame of reference for a qualitative discussion under the alternatives.

The discussion of potential jobs and income impacts typically occurs alongside consideration of non-market and social values. Changes to goods and services provided by the BLM can affect employment and income in the area. However, employment and income would likely be supported in other areas if a substitute for livestock grazing is provided by other means.

Effects on cultural and social values related to bighorn sheep are also discussed qualitatively in the non-market and social values sections below, because the value of bighorn sheep-associated recreational experiences cannot be characterized solely on their market transactions.

\section{Non-market and Social Values}

Non-market values, such as the value of recreation experiences and ecological services, by their nature are difficult to quantify. Direction provided in the BLM's Land Use Planning Handbook (Appendix D; pages 6,7 and 10) suggests the use of benefit transfer to evaluate the effects of these non-market values. Since levels of recreation related to bighorn sheep are not known, the total change in non-market value cannot be assessed quantitatively; however, qualitative discussion is included relative to non-market values discussed in Chapter 3.

The qualitative discussion of change in non-market and social values is based on estimated effects on bighorn sheep hunting opportunities in the impact area, the probability of herd extirpation (Table 4-8, Table 4-9, and Table 4-10 of the wildlife section), and acres of protected bighorn sheep habitat (Table 4-6 of the wildlife section) under the alternatives. These factors allow the determination of how the alternatives potentially degrade, maintain, or enhance non-market values associated with affected bighorn sheep. In addition, other non-market aspects of each alternative are described in other resource sections of this document as well as supporting technical reports. 


\subsubsection{Effects of Alternatives}

\subsubsection{Effects from Alternative A}

\section{Livestock Grazing}

Under Alternative A, domestic sheep grazing would continue on all four allotments, as shown in Table 4-17.

\begin{tabular}{|l|c|c|c|}
\hline Table 4-17: Alternative A - Continue Use of Domestic Sheep Allotments \\
\hline \multicolumn{1}{|c|}{ Allotment Name } & Acres & Season of Use & Permitted AUMs \\
\hline Partridge Creek & 9,544 & $4 / 11-7 / 15 \& 10 / 15-11 / 30$ & 431 \\
\hline Marshall Mountain & 4,212 & $7 / 5-8 / 4$ & 166 \\
\hline Hard Creek & 5,210 & $6 / 15-7 / 15$ & 218 \\
\hline Big Creek & 439 & $6 / 1-10 / 30$ & 81 \\
\hline Total & $\mathbf{1 9 , 4 0 5}$ & & $\mathbf{8 9 6}$ \\
\hline
\end{tabular}

Domestic sheep grazing on BLM lands in these allotments would continue to provide a source of forage to complement the lessees' sheep ranching operations on other lands.

Using the IMPLAN input-output model, estimates of the BLM employment and income contribution were calculated from the preference limit for this alternative (Table 4-18). Direct employment and labor income affect employees and their families; therefore, affecting the local economy. Indirect and induced multiplier effects (ripple effects) are then generated by the direct activities. Indirect effects accrue to connected industries when purchases are made in support industries and induced effects occur as employees spend wages in the impact area. Together, the direct and multiplier effects comprise the total economic impacts to the impact area economy.

Direct contributions to the agricultural sector from domestic sheep grazing on the four relevant allotments include an added 2.3 jobs to the impact area (Table 4-18). In addition, 0.5 indirect and induced jobs are supported in the impact area on an average annual basis through grazing on the four allotments. While this number may appear small, these employment and income estimates account for the portion attributable to use on BLM land and not the entire job, thus multiple lessees and their employees could be included in the estimate of a single job. For example, the 2.3 direct jobs could account for four people who work half of the year ( 2 total jobs annually) on forage provided by BLM and the last 0.3 jobs accounts for another family member who works a third of the year on forage provided by BLM.

Forage provided by the CFO provides an important source that complements additional sources during other parts of the year. Consequently, estimating the effect of livestock grazing using only BLM AUMs may underestimate the actual importance of BLM land as a forage resource; where a change in BLM grazing affects the optimal use of the rest of forage resources. Using the inputoutput methodology described above (and ranch production relationships presented in Chapter 3 ), consideration of the entire ranch production perspective attributes the additional direct and indirect employment and labor income from CFO sheep grazing (Table 4-18). 


\begin{tabular}{|c|c|c|c|c|c|c|}
\hline \multirow[b]{2}{*}{ Alternative } & \multicolumn{3}{|c|}{$\begin{array}{c}\text { Employment } \\
\text { (Full- and Part-time Jobs) }\end{array}$} & \multicolumn{3}{|c|}{$\begin{array}{l}\text { Labor Income } \\
\text { (2012 Dollars) }\end{array}$} \\
\hline & $\begin{array}{l}\text { Direct } \\
\text { Effects }\end{array}$ & \begin{tabular}{|c|}
$\begin{array}{c}\text { Indirect and } \\
\text { Induced } \\
\text { Effects }\end{array}$ \\
\end{tabular} & Total & $\begin{array}{l}\text { Direct } \\
\text { Effects }\end{array}$ & $\begin{array}{l}\text { Indirect and } \\
\text { Induced } \\
\text { Effects }\end{array}$ & Total \\
\hline Alternative $\mathrm{A}$ & 2.3 & 0.5 & 2.8 & 9,916 & 17,040 & 26,956 \\
\hline Alternative B & 0.2 & 0.0 & 0.3 & 896 & 1,540 & 2,437 \\
\hline Alternative $\mathrm{C}$ & 0.0 & 0.0 & 0.0 & 0.0 & 0.0 & 0.0 \\
\hline Alternative D & 0.6 & 0.1 & 0.8 & 2,733 & 4,697 & 7,431 \\
\hline Alternative E & 1.2 & 0.3 & 1.5 & 5,146 & 8,843 & 13,989 \\
\hline Alternative F & 0.8 & 0.2 & 0.9 & 3,215 & 5,524 & 8,740 \\
\hline \multicolumn{7}{|c|}{ Ranch Production Perspective } \\
\hline Alternative A & 2.8 & 0.7 & 3.4 & 11,998 & 20,619 & 32,617 \\
\hline Alternative B & 0.2 & 0.1 & 0.3 & 1,085 & 1,864 & 2,949 \\
\hline Alternative C & 0.0 & 0.0 & 0.0 & 0.0 & 0.0 & 0.0 \\
\hline Alternative D & 0.8 & 0.2 & 0.9 & 3,308 & 5,684 & 8,991 \\
\hline Alternative E & 1.4 & 0.3 & 1.8 & 6,227 & 10,701 & 16,927 \\
\hline Alternative F & 0.9 & 0.2 & 1.1 & 3,890 & 6,685 & 10,575 \\
\hline
\end{tabular}

The impact area is dependent on agriculture for 13.5 percent of employment and can be considered specialized with respect to employment in the subsector that includes sheep grazing (animal production except cattle, poultry, and eggs) (Figure 3-4). Under Alternative A, 5.1 direct jobs could be contributed (from both grazing on BLM and the ranch production perspective) to the sheep grazing subsector depicted in Figure 3-4. This represents the maximum possible contribution from BLM allotments if all permitted grazing under Alternative A were to occur. These maximum potential contributions would represent approximately 5 percent of employment in the subsector that includes sheep grazing, and less than 0.5 percent in the agriculture sector within the three-county impact area.

Ranching has played a historic role in the community. Because grazing would resume should the BLM decide to make these allotments available for domestic sheep grazing, the quality of life associated with grazing on BLM land (see Chapter 3, Non-market and Social Values, page 3-36, for discussion of quality of life associated with grazing on the BLM) could continue under Alternative A. In addition, associated quality of life for ranching could be higher under this alternative than the others since the preference limit is higher and could thus accommodate increases in use with favorable market conditions and willing lessees.

\section{Bighorn Sheep-related Recreation}

Visitors often spend money in the impact area economy when participating in bighorn sheeprelated recreation. Visitor data for area National Forests are used for this analysis, as expenditures of these visitors specific to the CFO is not available. Analyses of the expenditures reported by National Forest visitors indicate that the primary factor in determining the amount spent by a visitor was the type of trip taken, not the specific activity or National Forest visited (Stynes and White 2005). In other words, recreation visits were distinguished for local visitors 
(individuals residing within 30 miles of the National Forest boundary) and nonlocal visitors (individuals residing more than 30 miles from the National Forest boundary). Local and nonlocal visitors were further divided by those staying overnight and those on day trips. The four trip type segments were:

- Nonlocal visitors on day trips

- Nonlocal visitors staying overnight

- Local residents on day trips

- Local residents staying overnight

National Visitor Use Monitoring data sample sizes were too small at the individual Forest level to sufficiently represent visitor spending profiles for hunting and viewing wildlife visits for individual Forests (Stynes and White 2006). To account for spending differences, profiles were estimated by grouping forests with above- or below-average spending, which were identified by comparing spending averages for each Forest with the national average ${ }^{8}$. The Nez Perce, Payette, and Wallowa Whitman National Forests were characterized as average-spending forests. These expenditures-per-visit are shown for all activity and trip types in Table 4-19.

\begin{tabular}{|c|c|c|c|c|}
\hline \multirow[t]{3}{*}{ Table 4-19: } & by Activity anc & rip Type & & \\
\hline & \multicolumn{4}{|c|}{ Expenditures (\$ per visit in 2012 dollars) } \\
\hline & $\begin{array}{l}\text { Nonlocal } \\
\text { Day Use }\end{array}$ & $\begin{array}{l}\text { Nonlocal } \\
\text { Overnight }\end{array}$ & $\begin{array}{c}\text { Local } \\
\text { Day Use }\end{array}$ & $\begin{array}{c}\text { Local } \\
\text { Overnight }\end{array}$ \\
\hline Downhill skiing & 55.72 & 275.83 & 31.17 & 142.62 \\
\hline Driving & 24.11 & 246.87 & 16.33 & 141.85 \\
\hline Snowmobile & 55.29 & 245.68 & 34.47 & 114.91 \\
\hline Cross-eountry skiing & 43.31 & 230.16 & 15.23 & 106.74 \\
\hline Hunting & 49.63 & 207.53 & 34.15 & 132.87 \\
\hline Hiking/biking & 22.32 & 202.73 & 11.84 & 64.29 \\
\hline Nature-related/Viewing Wildlife & 27.86 & 187.71 & 18.02 & 87.06 \\
\hline Fishing & 26.79 & 147.78 & 20.36 & 69.00 \\
\hline OHV-use & 46.72 & 123.67 & 29.59 & 62.43 \\
\hline Other & 25.72 & 117.87 & 16.48 & 74.21 \\
\hline Developed eamping & NA & 76.11 & NA & 59.11 \\
\hline Primitive Camping/baekpaeking & NA & 57.43 & NA & 53.58 \\
\hline \multicolumn{5}{|l|}{ Souree: USFS 2012} \\
\hline
\end{tabular}

Nonlocal Downhill skiers staying overnight spend the most while Local Hikers/Bikers spend the least. Nonlocal hunters staying overnight spend the fifth highest per visit (\$208) while nonlocal

\footnotetext{
${ }^{8}$ Day and overnight visitor spending averages (exeluding non-primary visitors) were estimated based on the sample of visitors on eaeh forest. To eontrol for differenees between day and overnight visitor trips aeross forests, a standardized average was eomputed for eaeh forest, assuming a fixed mix of 60 pereent for day trips and 40 pereent for overnight trips. The standardized average for eaeh forest was eompared to the national standardized average.

${ }^{9}$ Expenditures per visit were obtained by dividing average expenditures per party trip by average party size. Party sizes by primary activity are reported in Appendix A of Stynes and White (2006).
} 
wildlife viewers staying overnight spend the seventh most of all activity types (\$188). While expenditures per visit give some comparison between activity types, the economic impacts of these activities depend on the economic characteristics of the three-county impact area discussed above.

The estimated employment and labor income response coefficients by activity type are shown in Table 4-20. Response coefficients indicate the number of full- and part-time jobs and dollars of labor income generated per 1,000 visits by activity type; they are useful for understanding the economic effects tied to a given use level and for understanding the differences in employment and labor income effects by activity type. Response coefficients are unique to the three-county impact area depicted in Figure 3-3.

\begin{tabular}{|c|c|c|c|c|c|c|c|}
\hline \multirow{2}{*}{\multicolumn{2}{|c|}{ 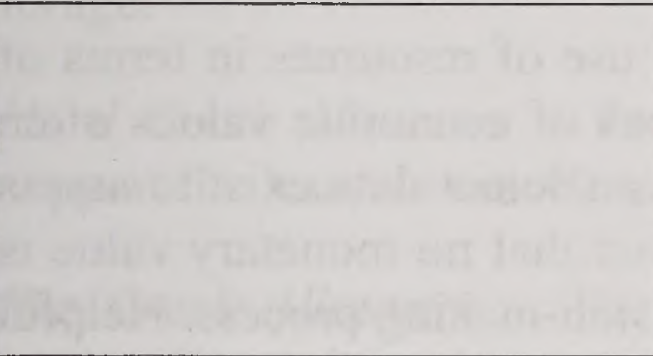 }} & \multicolumn{3}{|c|}{$\begin{array}{c}\text { Employment } \\
\text { (Jobs per 1,000 Visits) }\end{array}$} & \multicolumn{3}{|c|}{$\begin{array}{l}\text { Labor Income (2012 Dollars) } \\
\text { (\$ per 1,000 Visits) }\end{array}$} \\
\hline & & $\begin{array}{l}\text { Direct } \\
\text { Effects }\end{array}$ & $\begin{array}{l}\text { Indirect } \\
\text { and } \\
\text { Induced } \\
\text { Effects }\end{array}$ & Total & $\begin{array}{l}\text { Direct } \\
\text { Effects }\end{array}$ & $\begin{array}{l}\text { Indirect } \\
\text { and } \\
\text { Induced } \\
\text { Effects }\end{array}$ & Total \\
\hline \multirow{4}{*}{ Hunting } & Local Day & 0.23 & 0.05 & 0.28 & 5,150 & 1,288 & 6,438 \\
\hline & Local OVN & 0.69 & 0.18 & 0.87 & 17,203 & 4,275 & 21,478 \\
\hline & Nonlocal Day & 0.30 & 0.07 & 0.37 & 7,192 & 1,795 & 8,987 \\
\hline & Nonlocal OVN & 1.24 & 0.28 & 1.52 & 25,992 & 6,698 & 32,690 \\
\hline \multirow{4}{*}{ Viewing Wildlife } & Local Day & 0.15 & 0.03 & 0.18 & 2,812 & 729 & 3,542 \\
\hline & Local OVN & 0.49 & 0.12 & 0.61 & 10,671 & 2,735 & 13,406 \\
\hline & Nonlocal Day & 0.23 & 0.05 & 0.27 & 4,285 & 1,103 & 5,388 \\
\hline & Nonlocal OVN & 1.05 & 0.21 & 1.26 & 18,714 & 4,823 & 23,538 \\
\hline
\end{tabular}

The following generalizations are presented in Table 4-20:

- Local hunting and viewing wildlife generates lower employment and labor income effects per 1,000 visits than nonlocal visits, because local visitors spend less per visit (see Table 4-19).

- Economic effects vary across hunting and viewing wildlife activity types; the lowest employment and labor income contribution is tied to local day users viewing wildlife and the largest contribution is associated with nonlocal hunters who stay overnight.

While response coefficients may be greater for certain activity types, the economic effects to the impact area also depend on the number of visitors participating. Hunting or wildlife viewing attributable to opportunities affected under this SEIS are not available, thus the response coefficients provide a frame of reference for discussion of effects. These response coefficients reflect an economic structure that is a snapshot in time and, therefore, are not applicable to visitation numbers that are dramatically different from current recreation levels. If recreational activities and/or visits were to change radically, there would be a structural shift in the economy as spending patterns change, and these response coefficients would no longer reflect underlying economic processes. 
Because grazing use on BLM land would not change under Alternative A, the predicted probability of population persistence (Table 4-14) is ranked the lowest of all the alternatives. Consequently, fewer bighorn sheep potential hunting opportunities or other bighorn sheeprelated recreation (e.g., wildlife viewing) in the impact area would occur for this alternative, resulting in fewer employment and income contributions to the impact area.

As shown on Figure 3-4, the impact area is dependent on recreation-related sectors for 11 percent of employment and can be considered specialized with respect to portions of three sectors related to recreation: retail trade, passenger transport and arts, and entertainment and recreation. As a result, decreases in employment and income contributions to the recreation-related economy of the impact area would be highest under Alternative A.

\section{Non-market and Social Values}

The economic analysis assesses the economic effects of the direct use of resources in terms of jobs and income. This type of analysis does not include other types of economic values often referred to as non-market values, which are difficult to quantify. Insufficient data exist to assess the effects of management actions on these values. However, the fact that no monetary value is assigned to these values does not lessen their importance in the decision-making process. Helpful inferences can still be made using estimated effects on bighorn sheep hunting opportunities in the impact area, the probability of herd extirpation, and acres of protected bighorn sheep habitat (see Table 4-1 through Table 4-15 in Section 4.2).

Because the fewest bighorn sheep hunting opportunities are anticipated for Alternative A, levels for non-market values (bighorn sheep tags statewide were more than $\$ 40$ million in 2009 [O'Laughlin and Cook 2010]) could be lowest as well. Considering only the direct and indirect effects of the alternatives, these results suggest visitors and area residents would not experience the past level of value associated with higher population levels of bighorn sheep.

\subsubsection{Effects from Alternative B}

\section{Livestock Grazing}

Alternative B, the BLM preferred alternative, would prohibit domestic sheep grazing on the Partridge Creek, Marshall Mountain, and Hard Creek allotments (see Table 4-21). The Big Creek Allotment would remain available for domestic sheep grazing.

Table 4-21: Alternative B - Domestic Sheep Acreage and Forage Allocations

\begin{tabular}{|l|c|c|}
\hline \multicolumn{1}{|c|}{ Allotment Name } & $\begin{array}{c}\text { Acres/AUMs } \\
\text { Available }\end{array}$ & $\begin{array}{c}\text { Difference in Acres/AUMs from } \\
\text { Alternative A }\end{array}$ \\
\hline Partridge Creek & $0 / 0$ & $-9,544 /-431$ \\
\hline Marshall Mountain & $0 / 0$ & $-4,212 /-166$ \\
\hline Hard Creek & $0 / 0$ & $-5,210 /-218$ \\
\hline Big Creek & $439 / 81$ & No Change \\
\hline
\end{tabular}


Alternative B eliminates domestic sheep grazing on both allotments used by Carlson Livestock and one of two allotments used by Soulen Livestock. This amounts to a reduction of one hundred percent of the total number of domestic sheep AUMs from the BLM available to Carlson Livestock (597 of 597) and seventy-three percent (218 of 299) of the total domestic sheep AUMs available to Soulen Livestock.

Partridge Creek Allotment - Prohibiting domestic sheep use of the allotment would disrupt the historical year-round sheep operation and cause logistical and financial hardships on the lessee. The lessee would have to find an alternate method to move sheep across the landscape that would be limited to private or leased land.

Marshall Mountain Allotment - Prohibiting domestic sheep grazing on this allotment would disrupt the year round sheep operations of the lessee and cause them to find another source of forage.

Hard Creek Allotment - Prohibiting domestic sheep grazing would disrupt future options to support the lessee's ranching operation.

Big Creek Allotment - The Grazing lessee would be able to utilize the BLM allotment in conjunction with private property that surrounds the allotment, to provide forage and support ranching operations during the summer months (June through October).

Using the IMPLAN input-output model described above, estimates of the BLM employment and income contribution are calculated from the preference limit under this alternative. If grazing were to resume on the Big Creek allotment under Alternative B, direct contributions from sheep grazing on BLM lands to the agricultural sector would account for less than 0.5 jobs in the impact area. This alternative would support 3 fewer total jobs (direct, indirect, and induced) than Alternative A (Table 4-18).

As shown in Figure 3-4, the impact area is dependent on agriculture for 13.5 percent of employment and can be considered specialized with respect to the sheep grazing subsector (animal production except cattle, poultry, and eggs). Under Alternative B, 0.4 direct jobs could be contributed from grazing on BLM land and the ranch production perspective, to the subsector that includes sheep grazing depicted on Figure 3-4. Total employment effects (direct, indirect, and induced) would be approximately 6 jobs fewer than under Alternative A (Table 4-20). This represents the maximum possible effect from changes to grazing on $\mathrm{CFO}$ lands, using all permitted grazing under Alternative $\mathrm{A}$ as a reference point for past levels of use. These maximum potential effects would represent 5 percent of employment in the subsector that includes sheep grazing and less than 0.5 percent in the agriculture sector within the three-county impact area. Currently there is no grazing on the Big Creek allotment, therefore no effect relative to current conditions would occur.

Ranching has played a historic role in the community. Since the preference limit is lower than the other alternatives it would accommodate lower levels of use than the other alternatives, apart from Alternative $\mathrm{C}$ (with favorable market conditions and willing lessees). Consequently, quality of life associated with grazing on BLM land would be less than the other alternatives, apart from 
Alternative C. (See Chapter 3, Non-market and Social Values, page 3-36, for discussion of quality of life associated with grazing.)

The BLM has assumed that for allotments where domestic sheep grazing is prohibited, a qualified applicant would apply for and, after a BLM site-specific analysis is conducted, receive authorization to graze cattle. Under this assumption, decreases in employment and income relative to Alternative A could be regained, and effects on the social role of ranching in the community could be reduced.

\section{Bighorn Sheep-related Recreation}

Since grazing use on the BLM would only be allowed on the Big Creek Allotment, the predicted probability of population persistence (Table 4-14) is ranked the highest of all the alternatives, except for Alternative C. Consequently, more bighorn sheep potential hunting opportunities and other bighorn sheep-related recreation (e.g., wildlife viewing) would be provided, resulting in more employment and income contributions to the impact area, except for Alternative C.

As shown in Figure 3-4, the impact area is dependent on recreation-related sectors for 10 percent of employment and can be considered specialized with respect to retail trade, passenger transport and arts, and entertainment and recreation. As a result of this alternative, employment and income contributions to the recreation-related economy of the impact area would be greatest among all the alternatives, except for Alternative C.

\section{Non-market and Social Values}

With the exception of Alternative C, Alternative B would have more bighorn sheep hunting opportunities than for any of the other alternatives; consequently, levels of non-market values (bighorn sheep tags statewide were more than $\$ 40$ million in 2009 [O'Laughlin and Cook 2010]) could be highest as well. Other non-market values associated with bighorn sheep would be highest as well, since the predicted probability of population persistence (Table 4-14) is ranked the highest. Considering only the direct and indirect effects of the alternatives, these results suggest visitors and area residents would experience levels of value associated with population levels of bighorn sheep that are higher than the other alternatives, again with the exception of Alternative C.

\subsubsection{Effects from Alternative C}

\section{Livestock Grazing}

Alternative $\mathrm{C}$ would prohibit domestic sheep grazing on all four allotments Table 4-22. Impacts for the Partridge Creek, Marshall Mountain, and Hard Creek allotments would be the same as described for Alternative B. In addition, prohibiting domestic sheep grazing on the 439 acres of public lands in the Big Creek Allotment would decrease the forage available by an additional 81 AUMs. 
Table 4-22: $\quad$ Alternative $C$ - Domestic Sheep Acreage and Forage Allocations

\begin{tabular}{|l|c|c|}
\hline \multicolumn{1}{|c|}{ Allotment Name } & $\begin{array}{c}\text { Acres/AUMs } \\
\text { Available }\end{array}$ & $\begin{array}{c}\text { Difference in Acres/AUMs from } \\
\text { Alternative A }\end{array}$ \\
\hline Partridge Creek & $0 / 0$ & $-9,544 /-431$ \\
\hline Marshall Mountain & $0 / 0$ & $-4,212 /-166$ \\
\hline Hard Creek & $0 / 0$ & $-5,210 /-218$ \\
\hline Big Creek & $0 / 0$ & $-439 /-81$ \\
\hline
\end{tabular}

Alternative $\mathrm{C}$ eliminates domestic sheep grazing on both BLM allotments use by Carlson Livestock and both allotments used by Soulen Livestock. This amounts to a reduction of one hundred percent of the total number of domestic sheep AUMs available to these two lessees.

Under this alternative, employment effects (direct, indirect, and induced) would be approximately 6 jobs fewer than under Alternative A (Table 4-18). This represents the maximum possible effect from changes to grazing within the CFO, using all permitted grazing under Alternative $\mathrm{A}$ as a reference point for past levels of use. These maximum potential effects would represent 6 percent of employment in the sheep grazing subsector and less than 0.5 percent in the agriculture sector within the three-county impact area. Currently, there is no grazing on the BLM allotments, therefore no effect relative to current conditions would occur.

Since no grazing would be permitted under this alternative, quality of life associated with sheep grazing on the CFO would not be supported, and decreases in available grazing would decrease the quality of life of individual operators. Currently, there is no grazing on these BLM allotments, therefore no effect relative to current conditions would occur. In addition, lessees would likely depend on other sources of forage on state and other private land.

The BLM has assumed that for allotments where domestic sheep grazing is prohibited, a qualified applicant would apply for and, after a BLM site-specific analysis is conducted, receive authorization to graze cattle. Under this assumption, decreases in employment and income relative to Alternative A could be regained, and effects on the social role of ranching in the community could be reduced.

\section{Bighorn Sheep-related Recreation}

The predicted probability of population persistence (Table 4-14) is ranked the highest of all the alternatives. Consequently, more potential bighorn sheep hunting opportunities other than bighorn sheep-related recreation (e.g., wildlife viewing) would be provided, resulting in more employment and income contributions to the impact area.

As shown on Figure 3-4, the impact area is dependent on recreation-related sectors for 10 percent of employment and can be considered specialized with respect to retail trade, passenger transport and arts, and entertainment and recreation. As a result of this alternative, employment and income contributions to the recreation-related economy of the impact area would be greatest among all the alternatives. 
More bighorn sheep hunting opportunities are anticipated under Alternative $\mathrm{C}$ than for any other alternative; consequently, levels of non-market values (bighorn sheep tags statewide were more than \$40 million dollars in 2009 [O'Laughlin and Cook 2010]) could be highest under this alternative. Other non-market values associated with bighorn sheep would be highest as well, since the predicted probability of population persistence (Table 4-14) is ranked the highest of all the alternatives. Considering only the direct and indirect effects of the alternatives, these results suggest visitors and area residents would experience the an increase of value associated with higher population levels of bighorn sheep.

\subsubsection{Effects from Alternative D}

\section{Livestock Grazing}

Alternative D would allow domestic sheep grazing on the Marshall Mountain and Big Creek allotments to continue, but would prohibit it on the Partridge Creek and Hard Creek allotments, for a total loss of 649 AUMs of forage for the lessees (Table 4-23).

Table 4-23: Alternative D - Domestic Sheep Acreage and Forage Allocations

\begin{tabular}{|l|c|c|}
\hline \multicolumn{1}{|c|}{ Allotment Name } & $\begin{array}{c}\text { Acres/AUMs } \\
\text { Available }\end{array}$ & $\begin{array}{c}\text { Difference in Acres/AUMs from } \\
\text { Alternative A }\end{array}$ \\
\hline Partridge Creek & $0 / 0$ & $-9,544 /-431$ \\
\hline Marshall Mountain & $4,212 / 166$ & No Change \\
\hline Hard Creek & $0 / 0$ & $-5,210 /-218$ \\
\hline Big Creek & $439 / 81$ & No Change \\
\hline
\end{tabular}

This alternative would eliminate domestic sheep grazing on one of two allotments used by Carlson Livestock and one of two allotments used by Soulen Livestock; amounting to a reduction of 72 percent (431 of 597) and 73 percent (218 of 299) of the total number of BLM domestic sheep AUMs available to Carlson Livestock and Soulen Livestock, respectively.

Using the IMPLAN input-output model, estimates of the BLM employment and income contribution are calculated from the preference limit under this alternative. If grazing were to resume on the Big Creek and Marshal Mountain allotments, direct contributions under this alternative from domestic sheep grazing on BLM lands to the agricultural sector would account for less than 1 job in the impact area. Relative to Alternative A, this alternative would support 2 total jobs (direct, indirect, and induced) less than Alternative A (Table 4-20).

Under this alternative, 1.4 direct jobs could be contributed (from both BLM grazing on the CFO and the ranch production perspective) to the sheep grazing subsector as depicted in Figure 3-5. Total employment effects (direct, indirect and induced) would be approximately 5 jobs fewer than for Alternative A (Table 4-18). This represents the maximum possible effect from changes to grazing on BLM land using all permitted grazing under Alternative A as a reference point. These maximum potential effects would represent 4 percent of employment in the subsector that includes sheep grazing and less than 0.5 percent in the agriculture sector within the three-county 
impact area. Currently, there is no grazing on the BLM allotments, therefore no effect relative to current conditions would occur.

Since the allocation is lower than for the other alternatives, Alternative D would accommodate lower levels of use than alternatives $\mathrm{A}$ and $\mathrm{E}$ (with favorable market conditions and willing lessees). Consequently, quality of life associated with grazing on BLM land would be less than alternatives A and E, but potentially greater than alternatives B and C. (See Chapter 3, Nonmarket and Social Values, page 3-36, for discussion of quality of life associated with grazing on the BLM land.)

The BLM has assumed that for allotments where domestic sheep grazing is prohibited, a qualified applicant would apply for and, after a BLM site-specific analysis is conducted, receive authorization to graze cattle. Under this assumption, decreases in employment and income relative to Alternative A could be regained, and effects on the social role of ranching in the community could be reduced.

\section{Bighorn Sheep-related Recreation}

Since grazing use on the BLM would be allowed on the Big Creek and Marshall Mountain allotments, the predicted probability of population persistence (Table 4-14) is less than that for alternatives $\mathrm{B}$ and $\mathrm{C}$, but greater than $\mathrm{A}, \mathrm{E}$, and $\mathrm{F}$. Consequently, more potential bighorn sheep hunting opportunities or other bighorn sheep-related recreation (e.g., wildlife viewing) would be provided, resulting in more employment and income contributions, than for alternatives A, E, and $\mathrm{F}$, but less than $\mathrm{B}$ and $\mathrm{C}$.

As shown in table 3-4, the impact area is dependent on recreation-related sectors for 10 percent of employment and can be considered specialized with respect to retail trade, passenger transport and arts, and entertainment and recreation. Employment and income contributions to the recreation-related economy of the impact area would be greater than alternatives $\mathrm{A}, \mathrm{E}$, and $\mathrm{F}$, but less than alternatives $\mathrm{B}$ and $\mathrm{C}$.

\section{Non-market and Social Values}

More bighorn sheep hunting opportunities are anticipated for Alternative D than other alternatives, with the exception of alternatives $\mathrm{B}$ and $\mathrm{C}$; consequently, levels of non-market values could be greater than for alternatives $\mathrm{A}$ and $\mathrm{E}$, but lower than for alternatives $\mathrm{B}$ and $\mathrm{C}$. Other non-market values associated with bighorn sheep would be greater as well, since the predicted probability of population persistence (Table 4-14) is ranked accordingly. These results suggest that visitors and area residents would experience more value associated with higher population levels of bighorn sheep than they would under alternatives $\mathrm{A}, \mathrm{E}$, and $\mathrm{F}$, but less than alternatives $\mathrm{B}$ and $\mathrm{C}$. 


\subsubsection{Effects from Alternative $E$}

\section{Livestock Grazing}

Alternative $\mathrm{E}$ would allow for domestic sheep grazing to occur on the Marshall Mountain, Hard Creek, and Big Creek allotments as shown in Table 4-24. With the exception of domestic sheep grazing being prohibited on Partridge Creek, impacts would be similar to those described for Alternative A.

Table 4-24: Alternative E-Domestic Sheep Acreage and Forage Allocations

\begin{tabular}{|l|c|c|}
\hline \multicolumn{1}{|c|}{ Allotment Name } & $\begin{array}{c}\text { Acres/AUMs } \\
\text { Available }\end{array}$ & $\begin{array}{c}\text { Difference in Acres/AUMs from } \\
\text { Alternative A }\end{array}$ \\
\hline Partridge Creek & $0 / 0$ & $-9,544 /-431$ \\
\hline Marshall Mountain & $4,212 / 166$ & No Change \\
\hline Hard Creek & $5,210 / 218$ & No Change \\
\hline Big Creek & $439 / 81$ & No Change \\
\hline
\end{tabular}

Alternative E would eliminate domestic sheep grazing on one of two allotments used by Carlson Livestock, amounting to a 72 percent reduction of the total number of BLM domestic sheep AUMs available to Carlson Livestock (431 of 597). There would be no reduction of the domestic sheep AUMs allocated to Soulen Livestock.

Using the IMPLAN input-output model, estimates of the BLM employment and income contribution are calculated from the allocations for this alternative. Direct contributions from sheep grazing on BLM land would account for 1.2 jobs in the impact area. Relative to Alternative A, this alternative would support approximately 1 less job (direct, indirect and induced) (Table 4-18).

For this alternative, 2.6 direct jobs could be contributed from both BLM grazing within the CFO and the ranch production perspective to the sheep grazing subsector depicted in Figure 3-4. Total employment effects (direct, indirect, and induced) would be approximately three jobs fewer than under Alternative A (Table 4-18). This represents the maximum possible effect from changes to grazing, using all permitted grazing under Alternative $\mathrm{A}$ as a reference point. These maximum potential effects would represent 3 percent of employment in the sheep grazing subsector and less than .5 percent in the agriculture sector within the three-county impact area. Currently, there is no grazing on the Big Creek Allotment, and thus no effect relative to current conditions would occur.

With the exception of Alternative A (with favorable market conditions and willing lessees), Alternative $\mathrm{E}$ would accommodate the highest levels of use; consequently, quality of life associated with grazing on BLM land would be greater than for the other alternatives.(See Chapter 3, Non-market and Social Values, page 3-36, for discussion of quality of life associated with grazing on BLM land.)

The BLM has assumed that for allotments where domestic sheep grazing is prohibited, a qualified applicant would apply for and, after a BLM site-specific analysis is conducted, receive authorization to graze cattle. Under this assumption, decreases in employment and income 
relative to Alternative A could be regained, and effects on the social role of ranching in the community could be reduced.

\section{Bighorn Sheep-related Recreation}

Since grazing use on the $\mathrm{CFO}$ would be allowed on all allotments except Partridge Creek, the predicted probability of population persistence (Table 4-14) is ranked the lowest of all the alternatives, apart from Alternative A. Consequently, fewer potential bighorn sheep hunting opportunities or other bighorn sheep-related recreation (e.g., wildlife viewing) would be provided, resulting in less employment and income contributions to the impact area.

As shown in Figure 3-4, the impact area is dependent on recreation-related sectors for 10 percent of employment and can be considered specialized with respect to portions of retail trade, passenger transport and arts, and entertainment and recreation. As a result of this alternative, employment and income contributions to the recreation related economy of the impact area would be the least among all the alternatives, apart from Alternative A.

\section{Non-market and Social Values}

With the exception of Alternative A, fewer bighorn sheep hunting opportunities are anticipated under Alternative $\mathrm{E}$ than for other alternatives; consequently, levels of non-market values could be lower under this alternative. Other non-market values associated with bighorn sheep would be lower as well, since the predicted probability of population persistence (Table 4-14) is ranked the lowest of all the alternatives, except for Alternative A. These results suggest that visitors and area residents would experience levels of value associated with population levels of bighorn sheep that are lower than the other alternatives, apart from Alternative A.

\subsubsection{Effects from Alternative $F$}

\section{Livestock Grazing}

Alternative F would allow domestic sheep grazing on the Hard Creek and Big Creek allotments to continue, but would prohibit domestic sheep grazing on the Partridge Creek and Marshall Mountain allotments (Table 4-25).

Table 4-25: Alternative F - Domestic Sheep Acreage and Forage Allocations

\begin{tabular}{|l|c|c|}
\hline \multicolumn{1}{|c|}{ Allotment Name } & Acres/AUMsAvailable & Difference in Acres/AUMsfrom Alternative A \\
\hline Partridge Creek & $0 / 0$ & $-9,544 /-431$ \\
\hline Marshall Mountain & $0 / 0$ & $-4,212 /-166$ \\
\hline Hard Creek & $5,210 / 218$ & $0 / 0$ \\
\hline Big Creek & $439 / 81$ & $0 / 0$ \\
\hline
\end{tabular}

This alternative would eliminate domestic sheep grazing on both allotments used by Carlson Livestock; Soulen Livestock would be unaffected. This amounts to a 100 percent reduction of the total number of BLM domestic sheep AUMs allocated to Carlson Livestock (597 of 597), and no reduction for Soulen Livestock. 
Using the IMPLAN input-output model, estimates of the BLM employment and income contribution are calculated from the preference limit for this alternative. If grazing were to resume on the Big Creek and Hard Creek allotments under this alternative, direct contributions from sheep grazing on BLM land to the agricultural sector would account for less than 1 job in the impact area. Relative to Alternative A, this alternative would support 1.4 total jobs (direct, indirect, and induced) less than Alternative A (Table 4-18).

Under Alternative F, 1.7 direct jobs could be contributed from both grazing on BLM land and the ranch production perspective to the sheep grazing subsector depicted in Figure 3-4. Total employment effects (direct, indirect, and induced) would be approximately 4 jobs less than under Alternative A (Table 4-20). This represents the maximum possible effect from changes to grazing on BLM land, using all permitted grazing under Alternative A as a reference point. These maximum potential effects would represent 4 percent of employment in the sheep grazing subsector and less than 0.5 percent in the agriculture sector within the three-county impact area. Currently, there is no grazing on these allotments, therefore no effect relative to current conditions would occur.

With the exception of alternatives B and C, Alternative F would accommodate the lowest levels of use; consequently, quality of life associated with grazing within the CFO would be less. (See Chapter 3, Non-market and Social Values, for discussion of quality of life associated with grazing on the CFO.)

The BLM has assumed that for allotments where domestic sheep grazing is prohibited, a qualified applicant would apply for and, after a BLM site-specific analysis is conducted, receive authorization to graze cattle. Under this assumption, decreases in employment and income relative to Alternative A could be regained, and effects on the social role of ranching in the community could be reduced.

\section{Bighorn Sheep-related Recreation}

With the exception of alternatives $\mathrm{A}$ and $\mathrm{E}$ (at low, moderate, and high inference for probability of disease outbreak given contact), the predicted probability of population persistence (Table 4-14) is ranked lowest of all the alternatives because grazing use within the CFO would only be allowed on the Big Creek and Hard Creek allotments; consequently, fewer bighorn sheep potential hunting opportunities and other bighorn sheep-related recreation (e.g., wildlife viewing) would be provided than under the other alternatives, resulting in less employment and income contributions to the impact area.

As shown in Figure 3-4, the impact area is dependent on recreation-related sectors for 10 percent of employment and can be considered specialized with respect to retail trade, passenger transport and arts, and entertainment and recreation. As a result of this alternative, employment and income contributions to the recreation-related economy of the impact area would be less than the other alternatives, apart from alternatives $\mathrm{A}$ and $\mathrm{E}$.

\section{Non-market and Social Values}

With the exception of alternatives $\mathrm{A}$ and $\mathrm{E}$, fewer bighorn sheep hunting opportunities are anticipated than for this alternatives; consequently, levels of non-market values could be lower. 
Other non-market values associated with bighorn sheep would be lower as well, since the predicted probability of population persistence (Table 4-14) is ranked the lowest of all the alternatives, except for alternatives A and E; suggesting that visitors and area residents would experience levels of value associated population levels of bighorn sheep that are lower than the other alternatives.

\subsubsection{Environmental Justice}

Direct effects on employment in the agricultural sector could disparately affect minority populations if sheepherders are predominantly minorities or ethnic groups. However, there is no current sheep grazing use on BLM allotments, thus no disparate effects relative to current conditions are possible. While changes in permitted levels of grazing under the alternatives are expected to result in indirect and induced changes in employment and labor income relative to current conditions, these changes would be spread throughout the population and would not disproportionately affect minority and low-income populations. These contributions would likely remain a small share of total employment and labor income within the planning area, but may be more important for smaller communities within the planning area.

Actions under the alternatives have potential effects on the area bighorn sheep population and could affect environmental justice populations within the impact area. Harvest ability depends on the bighorn sheep population available for hunting. Because the effect on harvest ability would be spread among all segments of the general population, Tribal, other minority, or low-income communities would not be disproportionately affected. Therefore, disparate effects to environmental justice populations within the impact area are not anticipated.

In addition, the Nez Perce Tribe is a cooperating agency in preparation of this SEIS and the BLM has considered input from the Tribe in this analysis.

\subsubsection{Cumulative Effects}

In the proximity of the analysis area domestic sheep grazing occurs on USFS, state, and private lands (see Map 9). Implementation of the recent Payette Forest Plan Amendment FSEIS/ROD (USFS 2010b) resulted in closure of seven of their domestic sheep allotments. For this analysis, the BLM assumed that the Allison Berg Allotment, which is adjacent to the BLM Partridge Creek Allotment and was temporarily closed by the Clearwater National Forest, would remain closed. The Carlson Livestock Company and Soulen Livestock Company also used some of these USFS allotments. For this analysis, the BLM assumed that Carlson Livestock Company will continue to graze sheep on their private and state lands in the Lower Salmon drainage, and Soulen Livestock Company will continue to graze sheep on private land south of New Meadows, adjoining the Big Creek Allotment and their USFS grazing permits outside of bighorn sheep habitat. Other domestic sheep grazing occurs across north-central Idaho under commercial operations and with small farm flocks. There is domestic sheep grazing on private lands south of Riggins along the Little Salmon to Tamarack (see Map 9).

Cumulative effects are examined for the same impact area assessed above. The economy can be affected by a variety of factors, including population growth, interest rate changes, location of new industries, recession, new sector growth, tax policy, and state economic policy. When 
compared to these types of variables, managing sheep grazing on the four BLM allotments has a relatively small regional effect. For example, the maximum potential effect from changes in sheep grazing under all the alternatives constitutes less than 0.5 percent of total employment in the impact area. Because the changes in economic activity previously discussed would be largely unnoticeable regionally, there should be no cumulative economic effects across the region. However, for individual sectors of the economy and smaller areas within the impact area, the cumulative effects are noteworthy.

Past and present cumulative economic activity has already been absorbed by the local economy. However, estimating the direct and indirect effects specific to other future reasonably foreseeable projects is not possible due to unavailable information specific to these projects. Individually, these projects would likely have a minimal impact on economic conditions; however, cumulatively they may affect employment and income levels in the impact area. The degree to which the economic environment would be impacted, as well as the distribution of effects, cannot be determined from the information available.

As noted in the analysis of employment and labor income impacts above, the maximum potential effect under the alternatives would represent approximately 6 percent of employment in the sheep grazing subsector and less than 0.5 percent in the agriculture sector within the three-county impact area (under Alternative C). Consequently, actions under this SEIS could have small cumulative economic impacts relative to the agriculture sector but larger effects relative to the subsector that includes sheep grazing. The degree to which the economic environment would be impacted, as well as the distribution of effects, cannot be determined from the information available. While specific quantitative cumulative economic effects are unknown, actions and trends affecting recreation related to bighorn sheep and the subsector that includes sheep grazing are discussed qualitatively below.

Cumulative management on adjacent USFS land has impacted current conditions under the No Action alternative. The USFS allotment closures impacted the year-round sheep operations of Carlson Livestock Company and Soulen Livestock Company.

The Payette National Forest FSEIS/ROD (USFS 2010b) noted that the traditional and historical role sheep grazing has played is declining. This decline is confirmed by decreasing state and county sheep inventories (USFS 2010a). In addition, the Payette National Forest Plan noted that urban communities will look to the Southwest Idaho Ecogroup National Forests with an increased need and desire to provide recreational and undeveloped areas, as USFS recreation visitor-days are projected to increase over time (USFS 2003; Table SO-18). This growth in recreation use may create additional recreation-related jobs in area communities, which could buffer recreation-related effects to industries and communities dependent on bighorn sheeprelated recreation, should bighorn sheep populations continue to decline.

Sheep grazing management on other lands (e.g., private, state, USFS) will cause additional bighorn sheep cumulative economic effects. Changes to the bighorn sheep populations from domestic sheep management on these other lands could potentially affect other forms of bighorn sheep related recreation, such as wildlife viewing and boating use. 


\subsection{IRRETRIEVABLE OR IRREVERSIBLE COMMITMENT OF RESOURCES}

Section 1502.16 of CEQ regulations requires the discussion of environmental consequences to include a description of "... any irreversible or irretrievable commitment of resources which would be involved in the proposal should it be implemented."

An irreversible commitment of resources refers to decisions impacting the use of nonrenewable resources (e.g., minerals). Since the alternatives for this RMP Amendment/SEIS address only renewable resources (e.g., forage and wildlife habitat), none of the alternatives would result in irreversible commitment of non-renewable resources.

An irretrievable commitment of resources refers to decisions that result in the loss of production or use of a resource. While all of the action alternatives would reduce domestic sheep and goat grazing, none of them would prevent grazing by other types of livestock. Therefore, the forage that is not available to domestic sheep and goats is not irretrievably lost. 
This page intentionally left blank. 


\section{GLOSSARY}


This page intentionally left blank. 
Animal Unit Month (AUM) - An Animal Unit Month (AUM) is the amount of forage to sustain one cow and her calf, one horse, or five sheep or goats for one month.

Allowable Uses - In accordance with the BLM Land Use Planning Handbook (BLM 2005), land use plans must identify uses, or allocations, that are allowable, restricted, or prohibited on the public lands and mineral estate. These allocations identify surface lands and/or subsurface mineral interests where uses are allowed, including any restrictions that may be needed to meet goals and objectives. Land use plans may also identify lands where specific uses are excluded to protect resource values.

Best Management Practices (BMPs) - Best Management Practices (BMPs) for domestic sheep and goat grazing include a variety of grazing lease or permit stipulations to reduce risks for domestic sheep or goats contacting bighorn sheep and potential for disease transmission. Typically these are implemented as a term and condition of the grazing lease or permit. In general, BMPs are techniques that guide, or may be applied to, management actions to aid in achieving desired outcomes. BMPs are often developed in conjunction with land use plans, but they are not considered a land use plan decision unless the plan specifies that they are mandatory. They may be updated or modified without a plan amendment if they are not mandatory. BMPs can be applied and monitored using adaptive management techniques. Similar to guidelines, rationale must be documented for deviating from applicable BMPs during implementation.

Big Game Management Unit - Units designated by the Idaho Department of Fish and Game for big game management purposes, such as hunting recommendations and setting population and demographic objectives.

Core Herd Home Range - The area within which most herd individuals spend most (95 percent) of their time.

Core Herd Home Range Analysis - Analysis used to estimate core herd home ranges from telemetry observations of individual bighorn sheep. First, fixed kernel analyses are used to estimate the home ranges of all observed individuals in a herd, and then those estimates are aggregated. The core herd home range is the area within the 95th volume contour of the aggregated home range estimates.

Desired Outcomes - In accordance with the BLM Land Use Planning Handbook (BLM 2005), land use plans must identify desired outcomes expressed in terms of specific goals and objectives.

Disease Model - A simulation model that uses the estimated rate of contacts between bighorn sheep and domestic sheep allotments to estimate the population's dynamics of bighorn sheep herds in the Salmon River and Hells Canyon metapopulations. The model incorporates estimates of current population sizes as well as demographic and disease impact parameters drawn from the literature on bighorn sheep biology. 
Effective Contact - Any contact between domestic and bighorn sheep resulting in the transmission of disease from the domestic sheep to the bighorn.

Epizootic - A disease attacking a large number of animals simultaneously. The disease is prevalent among a group of animals.

Extirpation - Extirpation, also known as local extinction, is the condition of a species which cease to exist in a specific geographic area, though it still exists elsewhere.

Fixed Kernel Analysis - A method of mapping the core herd home range of an individual on the landscape that uses a standard bivariate normal (i.e., Gaussian) kernel density estimator (i.e., utilization distribution). Polygons are calculated from the volumes of the curve under different portions of the utilization distribution. Polygons are also calculated using a fixed-kernel approach which assumes the width of the standard bivariate normal kernel placed at each observation is the same throughout the plane of the utilization distribution.

Foray - A movement of a bighorn sheep outside of the core herd home range. Rams, in particular, make occasional long distance foray movements.

Foray Analyses - Analyses of the frequency and pattern of foray movements. For animals of each sex, and during each season ("Summer" = May-October, "Winter"= November-April), telemetry observations are used to determine the probability of a foray movement and the distribution of distances traveled in those forays.

Herd - A group of bighorn sheep that remain together as a loose group with a tighter group of breeding ewes as the core. Most of the Hells Canyon herds are named and identified based on a general geographical location they occur in or the group of reintroduced animals from which they descend. Used interchangeable with the term population or local population.

Metapopulation - A collection of populations that interact with each other due to occasional movement of animals between populations.

Planning Area - The planning area for this amendment process is limited to four BLM grazing allotments (Partridge Creek, Marshall Mountain, Hard Creek, and Big Creek ) in Idaho and Adams Counties of Idaho as depicted on Map 1.

Population - Interchangeable with the term "herd". (See above).

Population Management Unit - Metapopulations are divided into Population Management Units (PMU) which are designated by Idaho Department of Fish and Game. The PMU and the population, are the levels at which many management activities occur.

Risk of Contact Model - A model for predicting contact between bighorn sheep and domestic sheep expressed either as the expected number of contacts per year, or as the percent probability of at least one contact per year. The model uses the source habitat, core herd home range, and foray analyses results to generate the output. 
Source Environment - The composite of all environmental conditions occurring in a specified area and time that result in stationary or positive population growth.

Source Habitat - Those characteristics of macrovegetation and topography that contribute to positive population growth for a species in a specified area and time. It is different from habitats associated with species occurrence, which may or may not contribute to long-term population persistence. Source habitats contribute to source environments.

Source Habitat Capacity - All acres with the potential to provide habitat for bighorn sheep, based only on their requirement for escape terrain.

Source Habitat Model - GIS modeling, validated with telemetry observations, used to map areas of winter and summer bighorn source habitat. The model uses vegetation cover type and structure, along with topological variables (elevation, slope and aspect) to identify areas qualifying as bighorn source habitat. 
This page intentionally left blank. 


\section{REFERENCES}


This page intentionally left blank. 


\section{REFERENCES}

Akenson, J. J., and H. A. Akenson. 1992. Bighorn sheep movements and summer lamb mortality in central Idaho. In: Proceedings of the biennial symposium of the Northern Wild Sheep and Goat Council, vol. 8, 14-27.

Alevy, J, Fadali, E., and T.R. Harris. 2007. Analysis of Impacts of Public Land Grazing on the Elko County Economy and Mountain City Management Area: Economic Impacts of Federal Grazing in Elko County 3/1/2007. University Center for Economic Development in the Department of Resource Economics at the University of Nevada, Reno.

Beecham, J. J., Jr., C. P. Collins, and T. D. Reynolds. 2007. Rocky Mountain bighorn sheep (Ovis canadensis): A technical conservation assessment. USDA Forest Service, Rocky Mountain Region. http://www.fs.fed.us/r2/projects/scp/assessments/rockymountain bighornsheep.pdf (accessed December 13, 2007).

Bentz, J. A., and P. M. Woodard. 1988. Vegetation characteristics and bighorn sheep use on burned and unburned areas in Alberta. Wildlife Society Bulletin 16(2):186-193.

Berger, J. 1990. Persistence of different sized populations: an empirical assessment of rapid extinctions in bighorn sheep. Conservation Biology 4:91-98.

Berry, C. R., Jr. 1979. Impact of sagebrush management on riparian and stream habitat. In: Proceedings of the sagebrush ecosystem: A symposium, 192-209. Utah State University, College of Natural Resources, Logan, UT.

Besser, T. E., E. F. Cassirer, W. J. Foreyt, C. Herndon, D. P. Knowles, K. A. Potter, S. Srikumaran, and C. Yamada. 2012a. Short communications - survival of bighorn sheep (Ovis canadensis) commingled with domestic sheep in the absences of Mycoplasma ovipneumoniae. Journal of Wildlife Diseases, 48(1):168-172.

Besser, T. E., N. J. Anderson, K. Baker, D. L. Bruning, E. F. Cassirer, M. A. Highland, J. A. Jenks, K. Mansfield, J. M. Ramsey, J. B. Smith, and P. Wolff. 2012b. Causes of pneumonia epizootics among bighorn sheep, western United States, 2008-2010. Emerging Infectious Diseases, Vol. 18, No. 3:406-414.

Besser, T.E., E.F. Cassirer, M.A. Highland, P. Wolf, A. Justice-Allen, K. Mansfield, M.A. Davis, and W. Foreyt. 2013. Bighorn sheep pneumonia: Sorting out the cause of a polymicrobial disease. Preventive Veterinary Medicine 108:83-93.

Beyer, H. L. 2004. Hawth's Analysis Tools for ArcGIS. Available at: http://www.spatialecology.com/htools.

Biberstein, E. L. 1979. The pasteurelloses. In: CRC Handbook of Zoonoses, vol. 1, Sec. A, 495-514. CRC Press, Boca Raton, FL. 
Blaisdell, J. P., E. D. McArthur, and R. B. Murray. 1982. Managing intermountain rangelands - sagebrush-grass ranges. USDA, Forest Service, Intermountain Forest and Range Experiment Station, Ogden, UT. General Technical Report INT-134

Bleich, V. C., S. A. Holl, and J. D. Wehausen. 1990. Desert-dwelling mountain sheep: Conservation implications of a naturally fragmented distribution. Conservation Biology 4: 383-390.

Bleich, V. C., R. R. Ramey II, J. L. Rechel, and J. D. Wehausen. 1996. Metapopulation theory and mountain sheep: Implications for conservation. In: Metapopulations and wildlife conservation, ed. D. R. McCullough, 353-373. Island Press, Washington DC.

Bleich, V. C., R. T. Bowyer, and J. D. Wehausen. 1997. Sexual segregation in mountain sheep: Resources or predation? Wildlife Monographs 134:1-50.

Blood, D. A. 1961. An ecological study of California bighorn sheep (Ovis canadensis californiana Douglas) in southern British Columbia. M.S. thesis, University of British Columbia.

Boyce, M. S., P. R. Vernier, S. E. Nielsen, and F. K. A. Schmiegelow. 2002. Evaluating resource selection functions. Ecological Modeling 157:281-300.

Brosnan, C. J., 1918. History of the State of Idaho. C. Scribner's sons, 1918. 237 pages

Buechner, H. K. 1960. The bighorn sheep in the United States, its past, present, and future. Wildlife Monographs 4:1-174.

Bunch, T. D., W. Boyce, C. P. Hibler, W. R. Lance, T. R. Spraker, and E. S. Williams. 1999. Diseases of North American wild sheep. In: Mountain sheep of North America, eds. R. Valdez and P. R. Krausman, 209-237. University of Arizona Press, Tucson, AZ.

Bunnell, F.L. 1982. The lambing period of mountain sheep - synthesis, hypotheses, and tests. Canadian Journal of Zoology - Revue Canadienne De Zollogie, 60, 1-14.

Cahn, M.L., M.M. Conner, O.J. Schmitz, T.R. Stephenson, J.D. Wehausen, and H.E. Johnson. 2011. Disease, population viability, and recovery of endangered Sierra Nevada bighorn sheep. The Journal of Wildlife Management 75(8): 1753-1766.

Callan, R. J., T. D. Bunch, G. W. Workman, and R. E. Mock. 1991. Development of pneumonia in desert bighorn sheep after exposure to a flock of exotic wild and domestic sheep. Journal of the American Veterinary Medical Association 198:1052-1056.

Carpenter, T.E., V.L. Coggins, C. McCarthy, C.S. O'Brien, J.M. O'Brien, and T. Schommer. 2014. A spatial risk assessment of bighorn sheep extirpation by grazing domestic sheep on public lands. Preventative Veterinary Medicine 114: 3-10.

Cassirer, E. F. 2013. Personal communication. Idaho Department of Fish and Game, Lewiston, ID. 
Cassirer, E. F., and A. R. E. Sinclair. 2007. Dynamics of pneumonia in a bighorn sheep metapopulation. Journal of Wildlife Management 71:1080-1088.

Cassirer, E.F., R.K. Plowright, K.R. Manlove, P.C. Cross, A.P. Dobson, K.A. Potter, and P.J. Hudson. 2013. Spatio-temporal dynamics of pneumonia in bighorn sheep. J. Animal Ecology 82:518-528.

Cassirer, E. F., V. L. Coggins, P. Fowler, D. L. Hunter, W. J. Foreyt, L. E. Oldenburg, and K. M. Rudolph. 1996. Overview and preliminary analysis of a bighorn sheep die-off, Hells Canyon 1995-96. In: Proceedings of the biennial symposium Northern Wild Sheep and Goat Council, vol. 10, 78-86.

Cassirer, E. F., V. L. Coggins, P. Fowler, D. L. Hunter, M. W. Miller, and K. M. Rudolph. 2001. Evaluation of ewe vaccination as a tool for increasing bighorn lamb survival following pasteurellosis epizootics. Journal of Wildlife Diseases 37:49-57.

Chalfant, Stuart A. 1974. Aboriginal territory of the Nez Perce Indians, in Nez Perce Indians (p. 83), edited by David Agee Horr, Garland Publishing Company.

Clark, D. and W. Hunter. 1992. "The Impact of Economic Opportunity, Amenities and Fiscal Factors on Age-Specific Migration Rates.” Journal of Regional Science 32(3): 349-365.

Clary, W. P., N. L. Shaw, J. G. Dudley, V. A. Saab, J. W. Kinney, and L. C. Smithman. 1996. Response of a depleted sagebrush steppe riparian system to grazing control and woody plantings. USDA Forest Service, Intermountain Research Station, Ogden, UT. Research Paper INT RP-492.

Coggins, V. L. 1988. The Lostine Rocky Mountain bighorn sheep die off and domestic sheep. In: Proceedings of the biennial symposium of the Northern Wild Sheep and Goat Council, vol. 6, 57-64.

Coggins, V. L. 2002. Rocky Mountain bighorn sheep/domestic sheep and domestic goat interactions: a management perspective. In: Proceedings of the biennial symposium of the Northern Wild Sheep and Goat Council, vol. 13, 165-174.

Coggins, V. L., and P. E. Matthews. 1992. Lamb survival and herd status on the Lostine bighorn herd following a Pasteurella die-off. Biennial Symposium of the Northern Wild Sheep and Goat Council 8:147-154.

Cook, J. G. 1990. Habitat, nutrition, and population biology of two transplanted bighorn sheep populations in southcentral Wyoming. PhD diss., University of Wyoming.

Council on Environmental Quality. 1997. Environmental justice guidance under the National Environmental Policy Act. Dated December 1997 
Dassanayake, R. P., D. R. Call, N. C. Casavant, D. P. Knowles A. A. Sawant, S. Srikumaran, and G. C. Weiser. 2010. Bibersteinia trehalosi inhibits the growth of Mannheimia haemolytica by a proximity-dependent mechanism. Applied and Environmental Microbiology 76:1008-1013.

Dassanayake, R. P., E. F. Cassirer, K. D. Clinkenbeard, W. J. Foreyt, C. N. Herndon, P. K. Lawrence, K. A. Potter, S. Shanthalingam, and S. Srikumaran. 2009. Mannheimia haemolytica serotype A1 exhibits differential pathogenicity in two related species, Ovis canadensis and Ovis aries. Veterinary Microbiology 133:366-371.

DeCesare, N. J. and D. H. Pletscher. 2006. Movements, connectivity, and resource selection of Rocky Mountain bighorn sheep. Journal of Mammalogy 87:531-538.

DeForge, J. R., D. A. Jessup, C. W. Jenner, and J. E. Scott. 1982. Disease investigation into high lamb mortality of desert bighorn in the Santa Rosa Mountains, California. In transaction of Desert Bighorn Council's $26^{\text {th }}$ Annual Meeting, Borrego Springs, CA. April 7-9.

DeForge, J. R., S. D. Ostermann, C. W. Willmott, K. B. Brennan, and S. G. Torres. 1997. The ecology of Peninsular bighorn sheep in the San Jacinto Mountain, California. In transactions of Desert Bighorn Council's $41^{\text {st }}$ Annual Meeting, Grand Junction, CO. April 9-11.

Dodd, N. L., and W. W. Brady. 1986. Cattle grazing influences on vegetation of sympatric desert bighorn range in Arizona. Desert Bighorn Council Transactions 30:8-13.

Donachie, W. 2007. Pasteurellosis. Pages 224-235 In: Diseases of sheep, ed, I. D. Aitken. Blackwell Publishing, Oxford, U.K.

Douglas, C. L., and D. M. Leslie. 1999. Management of bighorn sheep. In: Mountain sheep of North America, eds. R. Valdez and P.R. Krasusman, 238-262. University of Arizona Press, Tucson, AZ.

Dubay, S., H. Schwantje, J. C. deVos, Jr., and T. McKinney. 2002. Bighorn sheep (Ovis canadensis) diseases: a brief literature review and risk assessment for translocation. In: Proceedings of the biennial symposium of the Northern Wild Sheep and Goat Council, vol. 13, 134-152.

EPS-HDT. 2012. Economic Profile System Human Dimensions Toolkit. Headwaters Economics, Forest Service and the BLM. http://www.headwaterseconomics.org.

Festa-Bianchet, M. 1986. Site fidelity and seasonal range use by bighorn rams. Canadian Journal of Zoology 64:2126-2132.

Festa-Bianchet, M. 1988. A pneumonia epizootic in bighorn sheep, with comments on preventive management. In: Proceedings of the biennial symposium of the Northern Wild Sheep and Goat Council, vol. 6, 66-76. 
Festa-Bianchet, M. 1989. Individual differences, parasites, and the costs of reproduction for bighorn ewes (Ovis canadensis). Journal of Animal Ecology 58:785-795.

Foreyt, W. J. 1989. Fatal Pasteurella haemolytica pneumonia in bighorn sheep after direct contact with clinically normal domestic sheep. American Journal of Veterinary Research 50:341-344.

Foreyt, W. J. 1990. Pneumonia in bighorn sheep: Effects of Pasteurella haemolytica from domestic sheep and effects on survival and long-term reproduction. In: Proceedings of the biennial symposium of the Northern Wild Sheep and Goat Council, vol. 7, 92-101.

Foreyt, W. J. 1992a. Failure of an experimental Pasteurella haemolytica vaccine to prevent respiratory disease and death in bighorn sheep after exposure to domestic sheep. In: Proceedings of the biennial symposium of the Northern Wild Sheep and Goat Council, vol. 8, 155-163.

Foreyt, W. J. 1992b. Experimental contact association between bighorn sheep, elk and deer with known Pasteurella haemolytica infections. In: Proceedings of the biennial symposium of the Northern Wild Sheep and Goat Council, vol. 8. p. 213-218.

Foreyt, W. J. 1994. Effects of controlled contact exposure between healthy bighorn sheep and llamas, domestic goats, mountain goats, cattle, domestic sheep, or mouflon sheep. In: Proceedings of the biennial symposium of the Northern Wild Sheep and Goat Council, vol. $9,7-14$.

Foreyt, W. J. 1998. Evaluation of a multivalent Pasteurella haemolytica toxoid-bacterin in protecting bighorn sheep from pneumonia after exposure to domestic sheep. In: Proceedings of the biennial symposium of the Northern Wild Sheep and Goat Council, vol. $11,18-26$.

Foreyt, W. J., and D. A. Jessup. 1982. Fatal pneumonia of bighorn sheep following association with domestic sheep. Journal of Wildlife Diseases 18:163-168.

Foreyt, W. J., and J. E. Lagerquist. 1996. Experimental contact of bighorn sheep (Ovis canadensis) with horses and cattle, and comparison of neutrophil sensitivity to Pasteurella haemolytica cytotoxins. Journal of Wildlife Diseases 32:594-602.

Foreyt, W. J., and R. M. Silflow. 1996. Attempted protection of bighorn sheep (Ovis canadensis) from pneumonia using a nonlethal cytotoxic strain of Pasteurella haemolytica, biotype A, serotype 11. Journal of Wildlife Diseases 32:315-321.

Foreyt, W. J., R. W. Kasten, and K. P. Snipes. 1994. Fatal pneumonia following inoculation of healthy bighorn sheep with Pasteurella haemolytica from healthy domestic sheep. Journal of Wildlife Diseases 30: 137-145.

Frank, G. H., M. W. Miller, and A. C. S. Ward. 2004. A review of Pasteurella pneumonia in domestic and wild sheep. Wyoming State-wide Bighorn/Domestic Sheep Interaction Working Group. Appendix J. 
Gaillard, J. M., M. Festa-Bianchet, N. G. Yoccoz, A. Loison, and C. Toïgo. 2000. Temporal variation in fitness components and population dynamics of large herbivores. Annual Review of Ecology and Systematics 31:367-393.

Garde, E., S. Kutz, H. Schwantje, and A. Veitch. 2005. Examining the risk of disease transmission between wild Dall's sheep and mountain goats, and introduced domestic sheep, goats and llamas in the Northwest Territories. The Northwest Territories Agricultural Policy Framework and Environment and Natural Resources, Government of the Northwest Territories, Canada.

Gasaway, W. C., R. O. Stephenson, J. L. Davis, P. E. K. Shepherd, and O. E. Burris. 1983. Interrelationships of wolves, prey, and man in interior Alaska. Wildlife Monographs 84:1-50.

Geist, V. 1971. Mountain sheep: a study in behavior and evolution. University of Chicago Press. $383 \mathrm{pp}$.

George, J. L., D. L. Martin, P. M. Lukacs, and M. W. Miller. 2008. Epidemic Pasteurellosis in a bighorn sheep population coinciding with the appearance of a domestic sheep. Journal of Wildlife Diseases 44:388-403.

Gilmour, N. J. L. and J. S. Gilmour. 1989. Pasteurellosis of sheep. In: Pasteurella and pasteurellosis, eds., C. Adlam and J. M. Rutter, 223-254. Academic Press, London.

Gilpin, M. E., and I. Hanski, eds. 1989. Metapopulation dynamics: Empirical and theoretical investigations. Academic Press San Diego, CA.

Goodson, N. J. 1982. Effects of domestic sheep grazing on bighorn sheep populations: a review. In: Proceedings of the biennial symposium of the Northern Wild Sheep and Goat Council, vol. 3, 287-313.

Grinnell, G. B. 1928. Mountain sheep. Journal of Mammalogy 9:1-9.

Gross, J. E., F. J. Singer, and M. E. Moses. 2000. Effects of disease, dispersal, and area on bighorn sheep restoration. Restoration Ecology 8:25-37.

Hall, E. R. 1981. The mammals of North America. 2nd ed. John Wiley, New York, NY.

Hanski, I. 1998. Metapopulation dynamics. Nature 396:41-49.

Heimer, W. E. and R. O. Stephenson. 1982. Responses of Dall sheep populations to wolf control in interior Alaska. Proceedings of the Biennial Symposium of the Northern Wild Sheep and Goat Council 3:320-329. 
Hells Canyon Bighorn Sheep Restoration Committee (HCBSRC). 1997. The Hells Canyon Initiative: Restoration of bighorn sheep to Hells Canyon. Idaho Department of Fish and Game, Oregon Department of Fish and Wildlife, Washington Department of Fish and Wildlife, U.S. Forest Service, Bureau of Land Management, Foundation for North American Wild Sheep. Idaho Department of Fish and Game, Lewiston, ID.

Hells Canyon Bighorn Sheep Restoration Committee (HCBSRC). 2004. The Hells Canyon Initiative: Hells Canyon bighorn sheep restoration plan. Idaho Department of Fish and Game, Oregon Department of Fish and Wildlife, Washington Department of Fish and Wildlife, U.S. Forest Service, Bureau of Land Management, Foundation for North American Wild Sheep. Idaho Department of Fish and Game, Lewiston, ID.

Hells Canyon Bighorn Sheep Restoration Committee (HCBSRC). 2005. Hells Canyon Initiative annual report FY 05. Idaho Department of Fish and Game, Oregon Department of Fish and Wildlife, Washington Department of Fish and Wildlife, U.S. Forest Service, Bureau of Land Management, Foundation for North American Wild Sheep. Idaho Department of Fish and Game, Lewiston, ID.

Hnilicka, P. A., Mionczynski, J., Mincher, B. J., Hinchberger, M., Oberlie, S., Thompson, C. B., Yates, B., and D. D. Siermer. 2002. Biennial Symposium Northern Wild Sheep and Goat Council 13:70-94.

Hobbs, N. T., and M. W. Miller. 1992. Interactions between pathogens and hosts: Simulation of pasteurellosis epizootics in bighorn sheep populations. In Wildlife 2001: Populations, eds. D. R. McCullough and R. H. Barrett, pp. 997-1007. Elsevier Science Publishers, Ltd., London.

Holleman, D. F. and R. O. Stephenson. 1981. Prey selection and consumption by Alaskan wolves in winter. Journal of Wildlife Management 45: 620-628.

Honess, R. F., and N. M. Frost. 1942. A Wyoming bighorn sheep study. Wyoming Game and Fish Department, Cheyenne, WY. Bulletin Number 1.

Hornocker, M. G. 1970. An analysis of mountain lion predation upon mule deer and elk in the Idaho primitive area. Wildlife Monographs 21: 1-39. http://fishandgame.idaho.gov/ public/wildlife/planBighorn.pdf

Hudson, W. E. ed. 1991. Landscape linkages and biodiversity. Island Press, Washington DC.

Huggard, D. J. 1993. Prey selectivity of wolves in Banff National Park: I. Prey Species. Canadian Journal of Zoology 71:130-139.

Hurley, K. 1999. Open Discussion - Are we effectively reducing interaction between domestic and wild sheep? In: Thomas, A.E., and H.L. Thomas, eds. Transactions of the Second North American Wild Sheep Conference; 1999 April 6-9; Reno, NV: 283-392. 
Husseman, J. S., D. L. Murray, G. Power, C. Mack, C. R. Wenger, and H. Quigley. 2003. Assessing differential prey selection patterns between two sympatic large carnivores. Oikos 101:591-601.

Idaho Department of Fish and Game (IDFG). 2004a. Bighorn sheep study I, Job 4. Project W-170-R-28, Progress Report. IDFG, Boise, ID.

Idaho Department of Fish and Game (IDFG). 2004b. Hells Canyon bighorn sheep; Study I: Hells Canyon Bighorn Sheep Restoration Plan. Project W-160-R-31, Progress Report. IDFG, Boise, ID.

Idaho Department of Fish and Game (IDFG). 2005. Idaho comprehensive wildlife conservation strategy. Idaho Conservation Data Center. http://fishandgame.idaho.gov/ public/wildlife/cwes/. Accessed July 11, 2013.

Idaho Department of Fish and Game (IDFG). 2006. Bighorn sheep study I, Job 4 Idaho Department of Fish and Game, Boise, ID. Project W-170-R-30, Progress Report.

Idaho Department of Fish and Game (IDFG). 2010. Bighorn Sheep Management Plan 2010. Idaho Department of Fish and Game, Boise, ID.

Idaho Department of Fish and Game and Idaho State Department of Agriculture (IDFG ISDA). 2007. Interim strategy for managing separation between bighorn sheep and domestic sheep in Idaho. Idaho Department of Fish and Game, Boise, Idaho. http://fishandgame.idaho.gov/public/wildlife/planBighornDomesticSheep.pdf

Idaho State Department of Agriculture. 2009. Strategy for Reducing Risk of Contact between Bighorn Sheep and Domestic Sheep in the Salmon River Area. Bureau of Land Management, Idaho Department of Fish and Game, Idaho Department of Lands, Boise, Idaho.

Idaho State Department of Agriculture. 2011. Idaho Agricultural Statistics. Issued by Idaho State Department of Agriculture in partnership with USDA National Agricultural Statistical Service

IMPLAN. 2010. Minnesota IMPLAN Group 2009. Data for purchase and additional information can be found at www.implan.com.

Jaeger, J. R. 1994. Demography and movements of mountain sheep (Ovis canadensis nelsoni) in the Kingston and Clark mountain ranges, California. M.S. thesis, University of Nevada, Las Vegas, NV.

Jaworski, M. D., D. L. Hunter, and A. C. S. Ward. 1998. Biovariants of isolates of Pasteurella from domestic and wild ruminants. Journal of Veterinary Diagnostic Investigation 10:49-55. 
Jenkins, E., S. J. Kutz, A. M. Veitch, B. Elkin, M. Chirino-Trejo, and L. Polley. 2000. Pneumonia as a cause of mortality in two Dall's sheep in the Mackenzie mountains, Northwest Territories, Canada. In: Proceedings of the biennial symposium of the Northern Wild Sheep and Goat Council, vol. 12, 40-53.

Jessup, D. A. 1985. Diseases of domestic livestock which threaten bighorn sheep populations. Desert Bighorn Council Transactions 1985:29-33.

Jessup, D. A., and W. M. Boyce. 1993. Diseases of wild sheep. In: Fowler, M.E., ed. Zoo and Wild Animal Medicine. Current Therapy 3.

Johnson, R. L. 1980. Re-introduction of bighorn sheep in Washington. Proceedings of the biennial meeting of the Northern Wild Sheep and Goat Council 2:106-112.

Jones, F. L. 1980. Competition. In: The desert bighorn, eds, G. Monson and L. Sumner, 197216. University of Arizona Press, Tucson, AZ.

Jones, L. C., and D. E. Worley. 1994. Evaluation of lungworm, nutrition, and predation as factors limiting recovery of the Stillwater bighorn sheep herd, Montana. In: Proceedings of the biennial symposium of the Northern Wild Sheep and Goat Council, vol. 9, 25-34.

Jorgenson, J. T., M. Festa-Bianchet, J. M. Gaillard, and W. D. Wishart. 1997. Effects of age, sex, disease, and density on survival of bighorn sheep. Ecology 78:1019-1032.

Josephy, A. M. 1971. The Nez Perce Indians and the opening of the northwest. (p. 561) Abridged Edition. Yale University Press.

Knapp, T. A., and P. E. Graves. 1989. On the Role of Amenities in Models of Migration and Regional Development. Journal of Regional Science 29(1): 71-87.

Kornet, S. D. 1978. An ecological survey of the White Mountain bighorn. Desert Bighorn Council Transactions 23:57-61.

Kovalchik, B. L., and W. Elmore. 1992. Effects of cattle grazing systems on willow-dominated plant associations in central Oregon. In Proceedings-Symposium on Ecology and Management of Riparian Shrub Communities, Sun Valley, ID, May 29-31, 1991, eds. W. P. Clary, E. D. McArthur, D. Bedunah, C. L. Wambolt. Ogden, UT: USDA Forest Service, Intermountain Research Station. General Technical Report INT-GTR-289.

Krueper, D. J. 1993. Effects of land use practices on western riparian ecosystems. In Status and Management of Neotropical Migratory Birds: Estes Park, CO, September 21-25, 1992, eds. D. M. Finch and P. W. Stangel. USDA Forest Service, Rocky Mountain Forest and Range Experiment Station, Fort Collins, CO. General Technical Report RM-229. 
Lawrence, P. K., S. Shanthalingam, R. P. Dassanayake, R. Subramaniam, C. N. Herndon, D. P. Knowles, R. R. Rurangirwa, W. J. Foreyt, G. Wayman, A. M. Marciel, S. K. Highlander, and S. Srikumaran. 2010. Transmission of Mannheimia haemolytica from domestic sheep (Ovis aries) to bighorn sheep (Ovis canadensis): unequivocal demonstration with green fluorescent protein-tagged organisms. Journal of Wildlife Diseases 46: 706-717.

Levins, R., T. Awerbuch, U. Brinkman, I. Eckardt, P. Epstein, N. Makhoul, C.A. de Possas, C. Puccia, A. Speilman, and M. E. Wilson. 1994. The emergence of new diseases. American Scientist 82:52-60.

Lewis, D., G. L. Hunt, and A. J. Plantinga. 2002. Public Conservation Land and Employment Growth in the Northern Forest Region. Land Economics 78(2): pp 245-259.

Mack, C. 2011. Salmon River bighorn sheep project annual report 2009-2010. Nez Perce Tribe, Lapwai, ID. 31 pp.

Manly, B. F., L. McDonald, and D. L. Thomas. 1993. Resource selection by animals: Statistical design and analysis of field studies. Chapman \& Hall, London. p. 177.

Marccouiller, D.W., and X. Xia. 2008. Distribution of income from tourism sensitive employment. Tourism Economics, 2008, 14 (3), 545-565

Marsh, H. 1938. Pneumonia in Rocky Mountain bighorn sheep. Journal of Mammalogy 19:214219.

Martin, K. D., T. Schommer, and V. L. Coggins. 1996. Literature review regarding the compatibility between bighorn and domestic sheep. In: Proceedings of the biennial symposium of the Northern Wild Sheep and Goat Council, vol. 10, 72-77.

McCarty, C. W., and M. W. Miller. 1998. Modeling the population dynamics of bighorn sheep: a synthesis of literature. Colorado Division of Wildlife, Denver, CO. Special Report Number 73.

McGranahan, D. 1999. Natural amenities drive population change. USDA Economic Research Service, Agricultural Economics. Report \#781.

McQuivey, R. P. 1978. The desert bighorn sheep of Nevada. Nevada Department of Wildlife, Las Vegas, NV. Biology Bulletin No. 6.

McWhirter, D., S. Smith, E. Merrill, and L. Irwin. 1992. Foraging behavior and vegetation responses to prescribed burning on bighorn sheep winter range. In: Proceedings of the biennial symposium of the Northern Wild Sheep and Goat Council, vol. 8, 264-278.

Miller, D. S., E. H. Hoberg, G. Weiser, K. Aune, M. Atkinson, and C. Kimberling. 2012. A review of hypothesized determinants associated with bighorn sheep (Ovis canadensis) die-offs. Hindaw Publishing Corporation, Veterinary Medicine International, Volume 2012, Article ID 796527. 19pp. 
Miller, M. W. 2001. Pasteurellosis. In Infectious Diseases of Wild Mammals, eds. E. S. Williams and I. K. Barker, 330-337. Iowa State University Press, Ames, IA.

Miller, M. W., J. M. Bulgin, J. A. Conlon, B. J. Kraabel, and H. J. McNeil. 1995. Strategies for managing infectious diseases in mountain sheep populations. Wildlife Research Report, Mammals Research, Federal Aid Projects, Job Progress Report, Project W-153R-8, WP2a, J4. Colorado Division of Wildlife, Fort Collins, CO. p. 151-161.

\section{Miller, M. W., D. C. Bowden, V. Jurgens, S. Roush, A. Torres, J. E. Vayhinger, and} T. Verry. 2000. Drug treatment for lungworm in bighorn sheep: Reevaluation of a 20-year-old management prescription. Journal of Wildlife Management 64:505-512.

Miller, M. W., N. T. Hobbs, and E. S. Williams. 1991. Spontaneous pasteurellosis in captive Rocky Mountain bighorn sheep. (Ovis canadensis canadensis): Clinical, laboratory, and epizootiological observations. Journal of Wildlife Diseases 27:534-542.

Monello, R. J., D. L. Murray, and E. F. Cassirer. 2001. Ecological correlates of pneumonia epizootics in bighorn sheep herds. Canadian Journal of Zoology-Revue Canadienne De Zoologie 79:1423-1432.Literature Cited Payette National Forest FSEIS 10

Mueser, P.R., and P.E. Graves. 1995. "Examining the Role of Economic Opportunity and Amenities in Explaining Population Redistribution." Journal of Urban Economics 37(2): 176-200.

NatureServe. 2004. International ecological classification standard: Terrestrial ecological systems of the United States. Natural Heritage Central Databases. NatureServe, Arlington, VA.

Nez Perce Tribe. 2008. Letter from the Nez Perce Tribal Executive Committee to the Director (210), Bureau of Land Management. Nez Perce Tribe Protest of the Bureau of Land Management's PRMP/FEIS for the Cottonwood Field Office, Idaho. Lapwai, ID.

Nichols, L. and F. Bunnell. 1999. Natural history of thinhorn sheep. Pages 23-77 in R. Valdez and P. Krausman, eds. Mountain sheep of North America. University of Arizona Press, Tucson.

Noss, R. F. 1987. Corridors in real landscapes: a reply to Simberloff and Cox. Conservation Biology 1:159-164.

O'Brien, J.M., C.S. O'Brien, C. McCarthy, and T.W. Carpenter. In Press. Incorporating foray behavior into models estimating contact risk between bighorn sheep and areas occupied by domestic sheep. Wildlife Society Bulletin.

O'Laughlin, J., and P. S. Cook. 2010. Bighorn sheep and domestic sheep: current situation in Idaho. Report Number 30, Policy Analysis Group, College of Natural Resources, University of Idaho, Moscow, USA. 
Onderka, D. K., and W. D. Wishart. 1984. A major bighorn sheep die-off from pneumonia in southern Alberta. Biennial Symposium of the Northern Wild Sheep and Goat Council $4: 356-363$.

Onderka, D. K., and W. D. Wishart. 1988. Experimental contact transmission of Pasteurella haemolytica from clinically normal domestic sheep causing pneumonia in Rocky Mountain Bighorn Sheep. Journal of Wildlife Diseases 24(4):663-667.

Onderka, D. K., S. A. Rawluk, and W. D. Wishart. 1988. Susceptibility of Rocky Mountain bighorn sheep and domestic sheep to pneumonia induced by bighorn and domestic livestock strains of Pasteurella haemolytica. Canadian Journal of Veterinary Research $52: 439-444$.

Oregon Department Fish and Wildlife (ODFW). 1992. Oregon's bighorn sheep management plan, 1992-1997. Oregon Department of Fish and Game, Salem, OR.

Ough, W. D., and J. C. deVos, Jr. 1984. Intermountain travel corridors and their management implications for bighorn sheep. Desert Bighorn Council Transactions 28:32-36.

Pinkham, Josiah. 2007. Declaration of Josiah Pinkham. United States District Court for the District of Idaho, Case No. 07-151-BLW.

Plowright, R. K., K. Manlove, e. F. Cassirer, P. C. Cross, T. E. Besser, and P. J. Hudson. 2013. Use of exposure history it identify patterns of immunity to pneumonia in bighorn sheep. (Ovis Canadensis). PLOS ONE 8 (4) e61919.

Post, G. 1962. Pasteurellosis of Rocky Mountain bighorn (Ovis canadensis canadensis). Wildlife Disease 23:1-14.

Potts, M. K. 1937. Hemorrhagic septicemia in the bighorn of Rocky Mountain National Park. Journal of Mammalogy 18:105-106. Payette National Forest FSEIS Literature Cited 11

Queen, C., A. C. S. Ward, and D. L. Hunter. 1994. Bacteria isolated from nasal and tonsillar samples of clinically healthy Rocky Mountain bighorn sheep and domestic sheep. Journal of Wildlife Diseases 30:1-7.

Raphael, M. G., M. J. Wisdom, M. M. Rowland, R. S. Holthausen, B. C. Wales, B. M. Marcot, and T. D. Rich. 2001. Status and trends of habitats of terrestrial vertebrates in relation to land management in the Interior Columbia River Basin. Forest Ecology and Management. 153:63-88.

Risenhoover, K. L., and J. A. Bailey. 1985. Foraging ecology of mountain sheep: Implications for habitat management. Journal of Wildlife Management 49(3):797-804.

Risenhoover, K. L., J. A. Bailey, and L. A. Wakelyn. 1988. Assessing the Rocky Mountain bighorn sheep management problem. Wildlife Society Bulletin 16:346-352. 
Rodgers, A. R., A. P. Carr, H. L. Beyer, L. Smith, and J. G. Kie. 2007. HRT: home range tools for ArcGIS. Ontario Ministry of Natural Resources, Centre for Northern Forest Ecosystem Research, Thunder Bay, Ontario, Canada.

Ross, P. II, M. G. Jalkotzy, and M. Festa-Bianchet. 1997. Cougar predation on bighorn sheep in southwestern Alberta during winter. Canadian Journal of Zoology 74:771-775.

Rubin, E.S., W.M. Boyce, M.C. Jorgenson, S.G. Torres, C.L. Hayes, C.S. O'Brien, and D.A. Jessup. 1998. Distribution and abundance of bighorn sheep in the Peninsular Ranges, California. Wildlife Society Bulletin, 26, 539-551.

Rubin, E.S., W.M. Boyce, and E.R. Caswell-Chen. 2002. Modeling demographic processes in an endangered population of bighorn sheep. Journal of Wildlife Management, 66, 796810 .

Rudolph, K. M., D. L. Hunter, W. J. Foreyt, E. F. Cassirer, R. B. Rimler, and A. C. S. Ward. 2003. Sharing of Pasteurella spp. between free-ranging bighorn sheep and feral goats. Journal of Wildlife Diseases. 39: 897-903

Rush, W. M. 1927. Notes on diseases in wild game mammals: mountain sheep. Journal of Mammalogy 8:163-165.

Ryder, R. J., E. S. Williams, K. W. Mills, K. H. Bowles, and E. T. Thorne. 1992. Effect of pneumonia on population size and lamb recruitment in Whiskey Mountain bighorn sheep. In: Proceedings of the biennial symposium of the Northern Wild Sheep and Goat Council, vol. 8, 136-146.

Sappington, J. M., K. M. Longshore, D. B. Thomson. 2007. Quantifying landscape ruggedness for animal habitat analysis: A case study using bighorn sheep in the Mojave Desert. Journal of Wildlife Management 71(5): 1419-1426.

Sawyer, H., and F. Lindzey. 2002. A review of predation on bighorn sheep (Ovis canadensis). Wyoming Cooperative Fish and Wildlife Research Unit, Laramie, WY. 36pp.

Schommer, T. J., and M. Woolever. 2001. A process for finding management solutions to the incompatibility between domestic and bighorn sheep. USDA Forest Service, WallowaWhitman National Forest, Baker City, OR.

Schommer, T. J. 2009. Evaluation of "Best Management Practices". USDA Forest Service, Wallowa-Whitman National Forest, Baker City, OR. Schrag, S. J., and P. Wiener. 1995. Emerging infectious diseases: What are the relative roles of ecology and evolution? Trends in Ecology and Evolution 10:319-324.

Schwantje, H., D. Stepaniuk, and D. Zehnder. 2006. British Columbia wild and domestic sheep separation programs. Biennial Symposium of the Northern Wild Sheep and Goat Council 15. 
Schwartz, O. A., V. C. Bleich, and S. A. Holl. 1986. Genetics and the conservation of mountain sheep. Biology Conservation 37:179-190.

Scott, M. E. 1988. The impact of infection and disease on animal populations: Implications for conservation biology. Conservation Biology 2:40-56.

Shackleton, D. 1999. Hoofed mammals of British Columbia. Royal British Columbia Museum and University of British Columbia Press, Vancouver, British Columbia, Canada. Literature Cited Payette National Forest FSEIS 12

Shanthalingam, S., and S. Srikumaran. 2009. Intact signal peptide of CD18, the beta-subunit of beta(2)-integrins, renders ruminants susceptible to Mannheimia haemolytica leukotoxin. In: Proceedings of the National Academy of Sciences of the United States of America, vol. 106, 15448-15453.

Shaw, N. L. 1992. Recruitment and growth of Pacific willow and sandbar willow seedlings in response to season and intensity of cattle grazing. In Proceedings of the Symposium on Ecology and Management of Riparian Shrub Communities, Sun Valley, ID. May 29-31, 1991, eds. W. P. Clary, E. D. McArthur, D. Bedunah, C. L. Wambolt. USDA Forest Service, Intermountain Research Station, Ogden, UT. General Technical Report INTGTR-289.

Silflow, R. S., and W. J. Foreyt. 1994. Susceptibility of phagocytes from elk, deer, bighorn sheep, and domestic sheep to Pasteurella haemolytica cytotoxins. Journal of Wildlife Diseases 30(4):529-535.

Silflow, R. S., W. J. Foreyt, W. W. Laegreid, R. W. Leid, H. D. Liggitt, and S. M. Taylor. 1989. Comparison of pulmonary defense mechanisms in Rocky Mountain bighorn sheep (Ovis canadensis canadensis) and domestic sheep. Journal of Wildlife Diseases 25:514520.

Silflow, R. S., W. J. Foreyt, W. W. Laegreid, R. W. Leid, H. D. Liggitt, and S. M. Taylor. 1991. Comparison of arachidonate metabolism by alveolar macrophages from bighorn and domestic sheep. Inflammation 15:43-54.

Simberloff, D., and J. Cox. 1987. Consequences and costs of conservation corridors. Conservation Biology 1:63-71.

Singer, F. J., and M. A. Gudorf. 1999. Restoration of bighorn sheep metapopulations in and near 15 national parks: Conservation of a severely fragmented species. Midcontinent Ecological Science Center, U.S. Geological Survey, Fort Collins, CO. Open File Report 99-102.

Singer, F. J., C. M. Papouchis, and K. K. Symonds. 2000a. Translocations as a tool for restoring populations of bighorn sheep. Restoration Ecology 8:6-13.Payette National Forest FSEIS Literature Cited 13 
Singer, F. J., M. W. Miller, E. Williams, and L. C. Zeigenfuss. 2000b. Population growth, fecundity, and survivorship in recovering populations of bighorn sheep. Restoration Ecology 8:75-84.

Singer, F. J., S. Bellew, M. E. Moses, and W. Sloan. 2000c. Correlates to colonizations of new patches by translocated populations of bighorn sheep. Restoration Ecology 8:66-74.

Singer, F. J., V. C. Bleich, and M. A. Gudorf. 2000d. Restoration of bighorn sheep populations in and near western national parks. Restoration Ecology 8:14-24.

Singer, F. J., L. Spicer, and L. C. Zeigenfuss. 2001. Role of patch size, disease, and movement in rapid extinction of bighorn sheep. Conservation Biology 15:1347-1354.

Skinner, M. P. 1928. The elk situation. Journal of Mammalogy 9:309-317.

Smith, D. R. 1954. The bighorn sheep in Idaho: Its status life history and management. Idaho Department of Fish and Game, Boise, ID.

Spinden, Herbert Joseph. 1908. The Nez Perce Indians. American Anthropological Association. Memoirs, 2, (211-212).

Spraker, T. R., C. P. Hibler, G. G. Schoonveld, and W. S. Adney. 1984. Pathologic changes and microorganisms found in bighorn sheep during a stress-related die-off. Journal of Wildlife Diseases 20:319-327.

Srikumaran, S. 2007. Molecular basis for the enhanced susceptibility of bighorn sheep to pneumonia: How much do we know? Paper presented at Respiratory disease in mountain sheep: Knowledge gaps and future research. University of California, Davis, CA.

Steinkamp, M. J. 1990. The effect of seasonal cattle grazing on California bighorn sheep habitat use. M.S. thesis, Utah State University. Salt Lake City, UT.

Stynes, D. J. and E. White. 2005. Spending Profiles of National Forest Visitors, NVUM Four Year Report. Report to USDA Forest Service. Department of Park, Recreation and Tourism Resources, Michigan State University, East Lansing, MI.

Stynes, D. J. and E. White. 2006. Spending Profiles for National Forest Recreation Visitors by Activity. Report to USDA Forest Service. Department of Park, Recreation and Tourism Resources, Michigan State University, East Lansing, MI.

Thompson, G. G. 1991. Determining minimum viable populations under the Endangered Species Act. U.S. Department of Commerce, National Oceanic and Atmospheric Association Technical Memo NMFS F/NWC-198.

Thompson, R.W. and J.C. Turner. 1982. Temporal geographic variation in the lambing season of bighorn sheep. Canadian Journal of Zollogy - Revue Canadienne De Zollogie, 60, 1781-1793. 
Thorne, E. T. 1982. Diseases of wildlife in Wyoming. 2nd ed. Wyoming Game and Fish Department, Cheyenne, WY.

Tomassini, L., B. Gonzales, G. C. Weiser, and W. Sischo. 2009. An ecologic study comparing distribution of Pasteurella trehalosi and Mannheimia haemolytica between Sierra Nevada bighorn sheep, White Mountain bighorn sheep, and domestic sheep. Journal of Wildlife Diseases 45:930-940.

Toweill, D. E., and V. Geist. 1999. Return of royalty: Wild sheep of North America. Boone and Crockett Club and Foundation for North American Wild Sheep, Missoula, MT.

Treyz, G. I., D. S. Rickman, G. L. Hunt, and M. J. Greenwood. 1993. "The Dynamics of U.S. Internal Migration.” The Review of Economics and Statistics 75(2): 209-14.

United States Animal Health Association (USAHA). 2009. Recommendations on best management practices for domestic sheep grazing on public land ranges shared with bighorn sheep. USAHA Joint Working Group, Committee of Wildlife Diseases and Committee on Sheep and Goats.

U.S. Department of Agriculture Forest Service (USFS). 1988. Payette National Forest Land and Resource Management Plan. USDA Forest Service, Intermountain Region, Ogden, UT.

U.S. Department of Agriculture Forest Service (USFS). 1998. Economic and Social Conditions of Communities: Economic and Social Characteristics of Interior Columbia Basin Communities and an Estimation of Effects on Communities from the Alternatives of the Eastside and Upper Columbia River Basin DEIS.

U.S. Department of Agriculture Forest Service (USFS). 2003. Final Environmental Impact Statement Southwest Idaho Ecogroup Land and Resource Management Plans. Revised. USDA Forest Service, Intermountain Region, Ogden, UT.

U.S. Department of Agriculture Forest Service (USFS). 2010a. Southwest Idaho Ecogroup Land and Resource Management Plans Final Supplemental Environmental Impact Statement. USDA Forest Service, Intermountain Region, Ogden, UT.

U.S. Department of Agriculture Forest Service (USFS). 2010b. Record of Decision for the Final Supplemental Environmental Impact Statement and Forest Plan Amendment identifying suitable rangeland for domestic sheep and goat grazing to maintain habitat for viable bighorn sheep populations. Payette National Forest, McCall, ID.

U.S. Department of Agriculture Forest Service (USFS). 2010c. Southwest Idaho Ecogroup Land and Resource Management Plans Update to the Draft Supplemental Environmental Impact Statement. USDA Forest Service, Intermountain Region, Ogden, UT.

U.S. Department of Agriculture Forest Service (USFS). 2012. Natural Resource Information System, Human Dimensions Module, National Visitor Use Monitoring Data. 
U.S. Department of Agriculture Forest Service (USFS). 2013a. Bighorn sheep risk of contact tool users guide. USDA Forest Service, Intermountain Region, Prepared by: USDA FS Bighorn Sheep Working Group, CRITIGEN, Inc.

U.S. Department of Agriculture Forest Service (USFS). 2013b. Bighorn sheep risk of contact tool users guide - frequently asked questions version 1.0. FS/BLM Bighorn Sheep Working Group.

U.S. Department of Agriculture (USDA). 2012. National Agricultural Statistical Service. Quick Stat 2.0 query of County level inventory of sheep and lambs for Idaho counties. Available at http://www.nass.usda.gov/Quick_Stats/.

U.S. Department of Commerce, Bureau of Economic Analysis. 2011. Regional Economic Information System, Washington, DC. Tables CA05, CA05N and CA30. Accessed from EPS-HDT pages 5 and 14 of the measures report.

U.S. Department of Commerce, Census Bureau. 2011. County Business Patterns, Washington, DC Accessed from EPS-HDT page 3 of the services report.

U.S. Department of Commerce, Census Bureau. 2012. American Community Survey Office, Washington, DC. Census Bureau, Systems Support Division, Washington, DC. Accessed from EPS-HDT pages 1 and 12 of the demographics report.

U.S. Department of Labor, Bureau of Labor Statistics. 2011. Quarterly Census of Employment and Wages, Washington, DC. Accessed from EPS-HDT page 15 of the measures report.

U.S. Department of Labor, Bureau of Labor Statistics. 2012. Local Area Unemployment Statistics, Washington, DC. Accessed from EPS-HDT page 16 of the measures report.

U.S. Department of the Interior. 2013. U.S. Department of the Interior Economic Report FY 2012. Washington, DC.

U.S. Department of the Interior, Bureau of Land Management (BLM). 1981. Chief Joseph Management Framework Plan. U.S. Department of the Interior, Bureau of Land Management, Coeur d'Alene District, Cottonwood Field Office, Cottonwood, ID.

U.S. Department of the Interior, Bureau of Land Management (BLM). 1988. BLM Manual 6500. Washington, DC.

U.S. Department of the Interior, Bureau of Land Management (BLM). 1997. Idaho Standards for Rangeland Health and Guidelines for Livestock Grazing Management. USDI-BLM Idaho State Office, Boise, Idaho. 
U.S. Department of the Interior, Bureau of Land Management (BLM). 1998. Revised Guidelines for Management of Domestic Sheep and Goats in Native Wild Sheep Habitats (Washington Office IM No. 98-140). This directive was extended by IM No. 2000-030 to September 30, 2001. U.S. Department of the Interior, Bureau of Land Management, Washington, DC.

U.S. Department of the Interior, Bureau of Land Management (BLM). 2005. BLM Land Use Planning Handbook (H-1601-1). U.S. Department of the Interior, Bureau of Land Management, Washington, DC.

U.S. Department of the Interior, Bureau of Land Management (BLM). 2008a. BLM National Environmental Policy Act, Handbook H-1790-1. U.S. Department of the Interior, Bureau of Land Management, Washington, DC.

U.S. Department of the Interior, Bureau of Land Management (BLM). 2008b. Proposed Cottonwood Resource Management Plan and Final Environmental Impact Statement, Volumes I and II. U.S. Department of the Interior, Bureau of Land Management, Coeur d'Alene District, Cottonwood Field Office, Cottonwood, ID.

U.S. Department of the Interior, Bureau of Land Management (BLM). 2009a. Cottonwood Approved Resource Management Plan and Record of Decision. U.S. Department of the Interior, Bureau of Land Management, Coeur d'Alene District, Cottonwood Field Office, Cottonwood, ID.

U.S. Department of the Interior, Bureau of Land Management (BLM). 2009b. Director's Protest Resolution Report. U. S. Department of the Interior, Bureau of Land Management, Washington, DC.

U.S. Department of the Interior, Bureau of Land Management (BLM). 2011a. Notice of Temporary Closure to Sheep Grazing Within the Marshall Mountain Allotment 36284. March 15, 2011. U.S. Department of the Interior, Bureau of Land Management, Cottonwood Field Office, Cottonwood, ID.

U.S. Department of the Interior, Bureau of Land Management (BLM). $2011 \mathrm{~b}$. Idaho Separation Plan IM No. ID-2011-004. U.S. Department of the Interior, Bureau of Land Management, Idaho State Office, Boise, ID.

U.S. Department of the Interior, U.S. Geological Survey (USGS). 2010. The National Map LANDFIRE. LANDFIRE National Existing Vegetation Type layer. Available at http://landfire.cr.usgs.gov/viewer/.

Valdez, R., and P. R. Krausman. 1999. Description, distribution, and abundance of mountain sheep in North America. In Mountain sheep of North America, eds. R. Valdez and P. R. Krausman, 3-22. University of Arizona Press, Tucson, AZ.

Wakelyn, L. 1987. Changing habitat conditions on bighorn sheep ranges in Colorado. Journal of Wildlife Management 51:904-912. 
Walker, D. 1967. Mutual cross-utilization of economic resources in the Plateau: an example from aboriginal Nez Perce fishing practices. Washington State University Laboratory of Anthropology Report of Investigations No. 41, (16).

Ward, A. C. S., D. L. Hunter, M. D. Jaworski, P. J. Benolkin, M. P. Dobel, J. B. Jeffress, and G. A. Tanner. 1997. Pasteurella spp. in sympatric bighorn and domestic sheep. Journal of Wildlife Diseases 33:544-557.

Wehausen, J. D., S. T. Kelley, and R. R. Ramey II. 2011. Domestic sheep, bighorn sheep, and respiratory, disease; a review of the experimental evidence. California Fish and Game $97(1) ; 7-24$.

Weiser, G. C., W. J. DeLong, J. L. Paz, B. Shafii, W. J. Prices, and A. C. S. Ward. 2003. Characterization of Pasteurella multocida associated with pneumonia in bighorn sheep. Journal of Wildlife Diseases. 39: 536-544.

White, P. J., T. O. Lemke, D. B. Tyers, and J. A. Fuller. 2008. Initial effects of reintroduced wolves Canis lupus on bighorn sheep Ovis canadensis dynamics in Yellowstone National Park. Wildlife Biology 14:138-146.

Wild Sheep Working Group of the Western Association of Fish and Wildlife Agencies (WAFWA). 2012. Recommendations for domestic sheep and goat management in wild sheep habitat. Western Association of Fish and Wildlife Agencies. 24 pp.

Wilson, L. O. 1968. Distribution and ecology of desert bighorn sheep in southeastern Utah. Utah Department of Natural Resources, Utah Division of Fish and Game, Salt Lake City, UT. Publication No. 68-5.

Wisdom, M. J., R. S. Holthausen, B. C. Wales, C. D. Hargis, V. A. Saab, D. C. Lee, W. J. Hann, T. D. Rich, M. M. Rowland, W. J. Murphy, and M. R. Eames. 2000. Source habitats for terrestrial vertebrates of focus in the Interior Columbia Basin: Broad-scale trends and management implications. USDA Forest Service, Pacific Northwest Research Station, Portland, OR. General Technical Report PNW-GTR-485.

Wishart, W. 1975. Report and recommendations of the Rocky Mountain bighorn workshop group. Pages 165-207 in J.B. Trefethen, ed. The wild sheep in modern North America. Winchester Press, New York.

Wishart, W. 1978. Bighorn sheep. Pages 161-171 in J.L. Schmidt and D.L. Gilbert, eds. Big Game of North America: ecology and management. Stackpole Books, Harrisburg, PA.

Wishart, W. 2000. A working hypothesis for Rocky Mountain bighorn sheep management. Page 47-52 in Thomas, A.E. and H.L. Thomas, eds. Transactions of the $2^{\text {nd }}$ North American Wild Sheep Conference. April 6-9, 1999, Reno, NV. 470 pp.

Worton, B. J. 1995. Using Monte-Carlo simulation to evaluate kernel-based home-range estimators. Journal of Wildlife Management 59:794-800. 
This page intentionally left blank. 
INDEX 
This page intentionally left blank. 


\section{A}

Adams County, 3-30, 3-31, 3-35, 3-38

AMS (Analysis of the Management

Situation), 1-3

Analysis of the Management Situation. See also AMS, 1-3

Animal Unit Month. See also AUM, ES-3, ES-4, 1-2, 2-2, 2-5, 3-23

AUM (Animal Unit Month), ES-3, 2-2, 3-39

B

Best Management Practice. See also BMP, 2-7, 3-27, 4-6

Bibersteinia, 3-5, A-1, A-8

Big Game Management Unit, 3-9, D-1

Buffer, 2-6, 2-7, 3-20, 4-3, 4-6, 4-7, 4-38, B-1, B-9

C

CCD (Census County Division), 3-30, 3-31

Census County Division. See also CCD, $3-30$

CEQ (Council on Environmental Quality), 1-7, 2-3, 3-24, 4-39

CFR (Code of Federal Regulations), 1-1, $1-2,1-5,1-6,2-3,2-9,3-23,3-24,3-25$, 4-1

CHHR (Core Herd Home Range), ES-5, ES6, ES-9, ES-10, 2-3, 2-4, 2-6, 2-7, 2-8, 3-2, 3-10, 3-11, 3-12, 3-13, 3-14, 3-16, 4-2, 4-3, 4-4, 4-6, 4-8, 4-9, 4-10, 4-11, 4-12, 4-13, 4-14, 4-15, 4-17, B-1, B-4, B-5, B-6, B-7, B-8, B-9, B-10

Code of Federal Regulations. See also CFR, $1-1$

Cooperating agency, ES-2, 1-5, 4-37

Core Herd Home Range. See also CHHR, ES-6, 2-9, 3-11, 3-13, 4-4, 4-8, 4-9, 4-11, 4-12, 4-13, 4-14, 4-15, B-4, B-7, D-1

Council on Environmental Quality. See also CEQ, 2-3
D

Disease Model, 4-5

$\mathbf{E}$

Effective Contact, 3-15

EIS (Environmental Impact Statement), ES$1,1-1,1-3,1-5,2-3,2-9,3-1$

Environmental Impact Statement. See also EIS, ES-1, 1-1

Epizootic, 3-15, A-1, A-2, A-6, A-9

EPS-HDT (Economic Profile System Human Dimensions Toolkit), 3-33

Extirpation, ES-1, ES-7, 1-1, 3-14, 3-15, 3-38, 4-23, 4-28, A-6

F

Federal Land Policy and Management Act. See also FLPMA, 1-5

FEIS (Final Environmental Impact

Statement), ES-1, 1-1, 1-2, 1-3, 1-5, 1-6, 3-1, 3-18, 3-20, 3-23, 3-26, 3-29, 4-1, 4-2, 4-18, 4-21

Field Office. See also FO, ES-8, 1-5, B-3, B-4

Final Environmental Impact Statement. See also FEIS, ES-1, 1-1

FLPMA (Federal Land Policy and

Management Act), 1-5, 3-1, 3-23, 3-24

FO (Field Office), 1-5, C-2

Foray, ES-5, ES-6, 3-2, 3-4, 3-10, 3-12, 3-16, 4-4, 4-17, B-5, B-6, B-7, B-9, B-10, B-11

Foray Analyses, 4-4

FSEIS (Final Supplemental Environmental Impact Statement), 3-1, 3-10, 3-15, 4-16, 4-18, 4-37, 4-38, A-9, B-5

G

Game Management Unit. See also GMU, ES-5, 3-6, 3-8, 3-9, D-1

GIS (Geographic Information System), 4-22 
GMU (Game Management Unit), ES-5, 3-6, 3-8, 3-9

GPS (Global Positioning System), B-5, C-2 Grazing Lease, 2-2, 2-3, 3-24, 3-25, 3-26, $3-27,3-28,4-1,4-2,4-10, \mathrm{C}-1$

\section{H}

HCBSRC (Hells Canyon Bighorn Sheep Restoration Committee), ES-4, 3-3, 3-5, 3-7, 3-8, 3-18, B-1, B-2

Hells Canyon Bighorn Sheep Restoration Committee. See also HCBSRC, ES-4, 3-5

\section{I}

Idaho County, 3-30, 3-31, 3-35, 3-38

Idaho Department of Fish and Game. See also IDFG, ES-2, 1-6, B-3

Idaho Instruction Memorandum. See also IDIM, 1-7

Idaho State Department of Agriculture. See also ISDA, 3-26, 3-38

IDFG (Idaho Department of Fish and Game), ES-2, ES-4, ES-8, 1-6, 1-7, 2-7, 3-1, 3-2, 3-3, 3-4, 3-5, 3-6, 3-8, 3-9, 3-17, 3-18, 3-26, 3-27, 3-36, 3-37, A-9, B-1, B-3, B-4, C-1, D-1

Indian, 3-20, 3-21, 3-31

ISDA (Idaho State Department of Agriculture), 3-26

\section{L}

LANDFIRE (Landscape Fire and Resource Management Planning Tools), B-2

Lease, ES-8, 1-2, 2-2, 2-3, 3-24, 3-25, 3-26, $3-27,3-28,3-39,4-1,4-2,4-10, \mathrm{C}-1$

\section{M}

Management Framework Plan. See also MFP, 2-3

Metapopulation, ES-4, 3-1, 3-2, 3-3, 3-5, 3-7, 3-8, 3-9, 3-12, 4-3, 4-5, 4-16, B-3, B-4, B-10 MFP (Management Framework Plan), 2-3
$\mathbf{N}$

National Environmental Policy Act, NEPA, $1-7$

Native American, ES-2, ES-7, ES-9, ES-10, $1-5,2-2,2-8,2-9,3-1,3-20,3-31,4-1$, 4-18, 4-19

NEPA (National Environmental Policy Act), 1-7, 3-24

Nez Perce National Forest, ES-2, 1-6, 3-26, 3-29, 4-2, B-3, B-4

Nez Perce Tribe, ES-2, ES-7, 1-5, 1-6, 2-1, 2-7, 3-1, 3-20, 3-21, 3-22, 3-27, 4-18, 4-19, 4-37, B-3, B-4

O

ODFW (Oregon Department of Fish and Wildlife), 1-6, 3-7, 3-8, B-3

Oregon Department of Fish and Wildlife. See also ODFW, ES-2, 1-6, B-3

$\mathbf{P}$

Pasteurella, 3-5, 3-6, 3-7, 3-9, A-1, A-2, A-3, A-7, A-8, A-10

Payette National Forest, ES-2, ES-5, ES-6, 1-5, 1-6, 3-1, 3-9, 3-26, 3-27, 3-29, 3-39, 4-17, 4-38, A-3, B-3, B-4, B-5, D-1

PCPI (Per Capita Personal Income), 3-34 Per Capita Personal Income. See also PCPI, 3-34

Planning Area, 1-3, 3-1, 3-2, 3-21, 3-36, 3-37, 4-37

PMU (Population Management Unit), ES-4, 3-2, 3-3, 3-5, 3-9, A-9

Pneumonia, ES-4, ES-5, 3-5, 3-6, 3-7, 3-9, 3-15, 3-18, A-1, A-2, A-3, A-4, A-5, A-6, A-7, A-8, A-9, A-10

Population Management Unit. See also PMU, ES-4, 3-2, A-9

Predation (Predator), 3-16, 3-17, 3-18, A-8, B-1, B-2, C-1, C-2

PRMP (Proposed Resource Management Plan), ES-1, 1-1, 1-2, 1-3, 1-5, 1-6, 3-1, 3-18, 3-20, 3-23, 3-26, 3-29, 4-1, 4-2, 4-18, 4-21 
Proposed Resource Management Plan. See also PRMP, 1-1

\section{$\mathbf{R}$}

Range of Alternatives, ES-1, 1-1, 2-1

Rangeland Health, 2-2, 3-24, 3-26, 3-27, 3-28

Record of Decision. See also ROD, ES-1, ES-2, 1-1, 1-6

Resource Management Plan. See also RMP, ES-1, 1-1

Restraining Order, ES-1, ES-8, 1-1, 3-20, 3-25, 3-27

Risk of Contact Model, 3-11, 4-4, 4-5, 4-16, B-3

RMP (Resource Management Plan), ES-1, ES-2, ES-3, 1-1, 1-2, 1-3, 1-4, 1-7, 2-1, 2-2, 2-3, 2-7, 2-9, 3-3, 4-1, 4-2, 4-18, 4-39

ROD (Record of Decision), ES-1, 1-1, 1-2, 1-3, 2-1, 2-3, 2-9, 3-29, 4-1, 4-2, 4-16, 4-18, 4-37, 4-38

\section{$\mathbf{S}$}

Salmon River Bighorn Sheep Project. See also SRBSP, ES-2, 1-6, 3-4, B-4

SEIS (Supplemental Environmental Impact Statement), ES-1, ES-2, ES-3, ES-4, ES5, ES-7, 1-1, 1-2, 1-3, 1-5, 1-6, 1-7, 2-7, 2-9, 3-1, 3-2, 3-3, 3-10, 3-16, 3-20, 3-23, 3-25, 3-27, 3-28, 3-29, 3-37, 4-1, 4-3, 4-6, 4-7, 4-21, 4-22, 4-27, 4-37, 4-38, 4-39, B-5

Separation Response Plan, ES-3, 1-7, 2-3, 4-2

Source Environment, ES-6, 3-10, B-1

Source Habitat, ES-5, ES-6, ES-9, ES-10, 2-3, 2-6, 2-8, 2-9, 3-10, 3-11, 3-13, 3-16, 3-18, 3-19, 3-27, 4-3, 4-4, 4-5, 4-8, 4-9, 4-10, 4-11, 4-12, 4-13, 4-14, 4-16, 4-17, 4-19, 4-20, B-1, B-2, B-9, B-10, D-1

Source Habitat Capacity, B-2

Source Habitat Model, ES-5, ES-6, 3-10, 4-4, B-1, B-2, B-9

Special Recreation Permit. See also SRP, 3-35
SRBSP (Salmon River Bighorn Sheep Project), B-4

SRMA (Special Recreation Management Area), 3-35

SRP (Special Recreation Permit), 3-35

Supplemental Environmental Impact Statement. See also SEIS, ES-1, 1-1, 1-3, $1-5,3-1$

\section{T}

Telemetry, ES-6, 2-1, 3-2, 3-3, 3-4, 3-11, 3-12, 4-5, B-2, B-3, B-4, B-5, B-7, B-9, D-1

TPI (Total Personal Income), 3-34, 3-35

\section{$\mathbf{U}$}

United States Department of Agriculture Forest Service. See also USFS, ES-5, 2-1, 3-29, A-8, B-3, D-1

United States Department of Agriculture.

See also USDA, 3-26, 3-38, A-8

United States District Court, 1-1, 3-20, 3-27

USDA (United States Department of

Agriculture), 3-38, A-8

USFS (United States Department of Agriculture Forest Service), ES-2, ES-5, ES-6, ES-7, 1-6, 2-1, 2-7, 3-1, 3-10, 3-11, $3-14,3-15,3-16,3-25,3-26,3-27,3-29$, 3-31, 4-2, 4-4, 4-5, 4-16, 4-17, 4-18, 4-22, 4-26, 4-37, 4-38, A-9, A-10, A-11, B-5, B-7, B-8, B-9, B-11

\section{V}

Very High Frequency. See also VHF, B-5 VHF (Very High Frequency), B-5

W

WAFWA (Western Association of Fish and Wildlife Agencies), ES-3, ES-4, 1-6, 3-2, 3-6, 3-7, 3-16, 3-17, A-3, A-7, A-10, A-11

Washington County, 3-29, 3-31, 3-38, 3-39

Western Association of Fish and Wildlife Agencies. See also WAFWA, ES-3, 1-6 
Western Watersheds Project. See also

WWP, 3-27

Wilderness Study Area. See also WSA, 1-3

Wolf, 3-17, 3-28
WSA (Wilderness Study Area), 1-3

WWP (Western Watersheds Project), 3-27, 3-29 


\section{Appendix A - Disease Transmission between Domestic Sheep and Bighorn Sheep}


This page intentionally left blank. 


\section{Respiratory Disease Outbreaks in Bighorn Sheep}

Early evidence of an association of bighorn sheep and domestic sheep with bighorn sheep dieoffs was largely anecdotal. A variety of field observations spanning many decades led to the hypothesis that bighorn sheep have a high probability of developing fatal pneumonia following contact with domestic sheep, and numerous attempts to disprove the contact hypothesis under controlled conditions have failed (Wehausen et al. 2011). Since at least 1937, multiple die-offs of bighorn sheep throughout North America have been documented in literature, and Pasteurella spp. were often cited as the cause (Potts 1937; Marsh 1938; Post 1962; Foreyt and Jessup 1982; Onderka and Wishart 1984; Spraker et al. 1984; Hobbs and Miller 1992; Ryder et al. 1992; McCarty and Miller 1998; Lawrence et al. 2010; Besser et al. 2012). As with other native North American wild ruminants, epidemics in bighorn sheep typically followed settlers and introduction of domestic livestock grazing and may have reflected an historical introduction of new pathogens into native wildlife populations by the late 1800s (Grinnell 1928; Skinner 1928; Honess and Frost 1942; Miller 2001). Limited understanding and/or access to bacteriological techniques probably precluded diagnoses of pasteurellosis in many early field investigations; consequently, the role of Pasteurella spp. in bighorn sheep epidemics was probably underestimated in studies reported prior to 1980 (Frank et al. 2004).

In North America, epizootic pneumonia is a devastating, outbreak of disease that rapidly affects many animals in a specific area at the same time, and has been identified as a population-limiting disease in bighorn sheep (Besser et al. 2012a; Cassirer and Sinclair 2007; Hobbs and Miller 1992; McCarty and Miller 1998; Monello et al. 2001; Miller 2001). Although various stressors and organisms are implicated in outbreaks of bacterial pneumonia in bighorn sheep, the most commonly associated organisms are bacteria in the genera Pasteurella and Mannheimia, in particular Mannheimia haemolytica (formerly Pasteurella haemolytical) and Bibersteinia trehalosi (formerly P. haemolytica biotype T) (Foreyt 1990). Both genera belong to the Pasteurellaceae - an incredibly large and diverse group of bacteria that continues to undergo reclassification (Garde et al. 2005). Pasteurella and Mannheimia spp. infect most mammalian families, as well as many if not all non-vertebrates (Miller 2001). They are common commensals (relationship between two organisms) on the mucous membranes of animal species in all climatic zones, most of whom are asymptomatic carriers (not producing indications of disease) (Biberstein 1979).

Miller and others (2012) identified that a clear, invariant (consistent) relationship between a single agent and field outbreaks has not yet been documented, in part due to methodological limitations and practical challenges associated developing rigorous study designs. However, to help clarify the uncertainty of pneumonia epizootics among bighorn sheep and uncertain etiology (cause or origination of disease), Besser and others (2012a) used culture and culture-independent methods to compare the prevalence of the bacterial respiratory pathogens Mannheimia haemolytica, Bibersteinia trehalosi, Pasteurella multocida, and Mycoplasma ovipneumoniae in lung tissue from 44 bighorn sheep from herds affected by 8 outbreaks in the western United States. The results of a Besser and others (2012a) study support a relationship between a single primary agent as the most consistently detected agent and the only agent that exhibited single strain types within each outbreak. The results of the Besser and others (2012a) study support the hypothesis that $M$. ovipneumoniae is a primary agent in the etiology of epizootic bighorn sheep 
pneumonia in populations across the western United States and that it acts to induce the secondary infection with opportunistic pathogens that take advantage of certain situations. The normal host range of $M$. ovipneumoniae (members of Old World Caprinae), is consistent with many observations that epizootic bighorn sheep pneumonia frequently follows contact with these hosts (Besser et al. 2012a). The likelihood of $M$. ovipneumoniae having a primary role in bighorn sheep pneumonia is consistent with the association between some epizootics of this disease and contact with domestic sheep because domestic sheep carry this agent at high prevalence (Besser et al. 2012a).

To test the hypothesis that $M$. ovipneumoniae is an important agent of the bighorn sheep pneumonia that has previously inevitably followed experimental commingling with domestic sheep, Besser and others (2012b) commingled $M$. ovipneumoniae-free domestic and bighorn sheep (4 each). One bighorn sheep died with acute pneumonia 90 days after commingling, but the other three remained healthy for $>100$ days. This unprecedented survival rate is significantly different $(\mathrm{P}=0.002)$ from that of previous bighorn-domestic sheep contact studies but similar to $(\mathrm{P}>0.05)$ bighorn sheep survival following commingling with other ungulates. The absence of epizootic respiratory disease in this experiment supports the hypothesized role of $M$. ovipneumoniae as a key pathogen of epizootic pneumonia in bighorn sheep commingled with domestic sheep (Besser et al. 2012b). The significant finding of this study was the unprecedented majority survival of bighorn sheep commingled with domestic sheep in the absence of $M$. ovipneumoniae. This finding is consistent with the hypotheses that $M$. ovipneumoniae is an important agent in epidemic pneumonia in bighorn sheep, but additional research will be required to substantiate this hypothesis further (Besser et al. 2012b).

Despite being ubiquitous among mammals, including native North American ruminants (Biberstein 1979; Thorne 1982; Jaworski et al. 1998), these bacteria cause only sporadic cases of pasteurellosis (usually associated with Pasteurella multocida) in bison, elk, moose, mountain goats, mule deer, and pronghorn (Thorne 1982). While pasteurellosis is one of the most common bacterial infections of domestic sheep, the most severe outbreaks kill 2.5 percent of the domestic sheep in a herd, not even close to the mortality seen in die-offs of bighorn sheep (Gilmour and Gilmour 1989; Donachie 2007; Miller 2001).

In contrast to most other wild and domesticated mammal species, bighorn sheep are notable in their extreme susceptibility to some strains of Pasteurellaceae (Miller 2001). Pneumonia associated with Pasteurella causes die-offs that can kill some, many, or all adult bighorn sheep in a herd (Bunch et al. 1999). Chronic or sporadic low levels of adult mortality and elevated mortality of lambs can continue for many years ( $>20$ years) further impairing population recovery and stability (Foreyt 1990; McCarty and Miller 1998; Miller et al. 2000; Cassirer et al. 2001; Miller 2001; Cassirer and Sinclair 2007; Frank et al. 2004; George et al. 2008; Cassirer et al. 2013). It has been speculated that once Pasteurella spp. have been introduced to bighorn sheep populations, they may become endemic and continue cycling for decades (Miller et al. 1991; Hobbs and Miller 1992; Miller et al. 1995) or until adult bighorn sheep previously exposed to pneumonia are removed from the population through natural mortality (Besser et al. 2012a, Plowright et al. 2013, Cassirer et al 2013).

Although a high likelihood for bighorn sheep mortality following direct contact with domestic sheep exists, domestic sheep appear to be resistant to most wild sheep pathogens (Martin et al. 
1996; Schommer and Woolever 2001). Furthermore, domestic sheep are often carriers of Pasteurella spp. but do not exhibit clinical signs. Marten and others (1996) summarized over 30 cases where bighorn die-offs are believed to have resulted from contact with domestic sheep. In many cases, over 50 percent of the bighorn herd died. Domestic sheep always remained healthy.

The physiological and cellular causes of bighorn sheep's susceptibility to Pasteurella spp. are an area of active research. On a general level, bighorn sheep did not co-evolve with the same set of pathogens as domestic sheep (Dubay et al. 2002), and domestic animals have likely been selected for disease resistance (Jessup 1985). Divergences in host-parasite co-evolutionary paths may explain observed differences in defense mechanisms between bighorn and domestic sheep (Silflow et al.1989).

Phenotypic traits (observable physical or biochemical characteristics) of Pasteurella spp. isolated from bighorn sheep are similar to those of isolates from domestic ruminants, so the susceptibility of bighorn sheep is due to the biology of the animals (Frank et al. 2004). Physiologically, domestic and bighorn sheep have different alveolar macrophage (surface of lung alveoli) function and arachidonic acid metabolism, which may cause increased sensitivity of bighorn sheep to respiratory disease (Silflow et al. 1991). Furthermore, in vitro studies have revealed a reduced capacity of bighorn sheep immune systems to kill bacteria compared with domestic sheep immune systems (Dubay et al. 2002). Silflow and Foreyt (1994) found that bighorn sheep neutrophils were more susceptible to cytotoxin (toxin effect on cells) damage than domestic sheep neutrophils (white blood cells essential for fighting disease). All ruminant leukocytes (specific type of white blood cell) are particularly susceptible to cytolysis (cell destruction) by the M. haemolytica leukotoxin (Shanthalingam and Srikumaran 2009). Leukotoxin secreted by M. haemolytica appears to be its main virulence factor in bighorn sheep, indicating that the basis of bighorn sheep's susceptibility to the bacteria may lie in the details of the interaction between leukotoxin and their leukocytes (Dassanayake et al. 2009).

Domestic goats have been implicated in fatal disease transmission to bighorn sheep. Some goats are carriers of Mannheimia and Pasteurella species that have been identified in bighorn sheep disease events. DNA analysis conducted during a 1995 to 1996 Hells Canyon bighorn die-off revealed that a feral goat and two bighorn sheep shared a genetically identical $P$. multocida and M. haemolytica (Rudolph et al. 2003; Weiser et al. 2003).

Developing immunity to pasteurellosis in bighorn sheep is complex and poorly understood (Miller 2001) and vaccines to protect bighorn sheep have proven ineffective (Foreyt 1992a; Foreyt 1998; Foreyt and Silflow 1996). Research is ongoing regarding the creation of a vaccine to protect bighorn sheep and it may be over a decade until such a vaccine is perfected (Dr. Subramaniam Srikumaran letter to Payette National Forest Supervisor).

\section{Evidence of Disease Transmission from Domestic Sheep}

The role that domestic sheep contribute to causing pneumonia in bighorn sheep is an important issue for wildlife management, livestock grazing, and multiple-use management (WAFWA 2012; Besser et al. 2012a; Cahn et al. 2011; Lawrence et al. 2010; Foreyt et al. 1994; Hurley 1999; Schommer and Woolever 2001; Schwantje et al. 2006). In the past 25 years, much research has been devoted to the question of whether contact with healthy domestic sheep leads 
to die-offs of bighorn sheep populations, due to the transmission of organisms that are nonpathogenic in domestic sheep but deadly in bighorn sheep. Evidence contributing to an answer to that question takes a variety of forms, each of which has its own inherent limitations. The next four sections discuss several types of evidence, derived from controlled experiments and field observations. The discussion notes the limitations of each type of observation and is structured to show how each one complements the others so that together they point toward a common conclusion that contact with domestic sheep does pose a risk to free-ranging bighorn sheep populations. Ultimately, the research shows that contact between bighorn sheep and domestic sheep and goats can lead to respiratory disease and fatal pneumonia in bighorn sheep (Besser et al. 2012a; Wehausen et al. 2011; Lawrence et al. 2010).

\section{Inoculation experiments}

Inoculation experiments have been used to test the hypothesis that healthy domestic sheep carry pneumonia-causing bacteria that can kill bighorn sheep. In one series of experiments, isolates of a particular strain of $M$. haemolytica from healthy domestic sheep were intratracheally inoculated into eight bighorn sheep and seven domestic sheep. Seven of the eight bighorn sheep died within 48 hours, whereas none of the seven domestic sheep showed symptoms (Foreyt et al. 1994). In two similar experiments, inoculation with $M$. haemolytica cultures from domestic sheep resulted in the death of five of five bighorn sheep (Foreyt and Silflow 1996; Onderka et al. 1988).

More recently, Dassanayake and others (2009) isolated a particular strain of the A1 serotype of $M$. haemolytica from domestic sheep that they thought would be fatal in bighorn sheep. While they typically carry both A1 and A2 serotypes, A2 serotypes are the primary cause of pneumonia in domestic sheep (Dassanayake et al. 2009). All four bighorn sheep injected with the strain died within 48 hours, while none of the domestic sheep were apparently affected by the bacteria. In addition, by injecting some bighorn sheep with a mutant of serotype Al from which the leukotoxin gene had been deleted, the researchers succeeded in pinpointing the single gene that is the primary virulence factor of $M$. haemolytica.

These inoculation experiments together indicate that domestic sheep carry at least some strains of bacteria that are not pathogenic to them but are highly lethal to bighorn sheep. Inoculation experiments themselves, however, cannot show whether such bacteria can be transmitted by contact between domestic and bighorn sheep.

\section{Pen experiments}

Pen experiments are designed to test the hypothesis that contact can lead to transmission of disease from domestic sheep to bighorn sheep. In a pen experiment, healthy bighorn sheep are put in contact or close proximity with healthy individuals of other species, and are watched for the development of disease. In six independent pen studies since 1982, 44 of 46 bighorn sheep have died of pneumonia or become so sick that they were euthanized (Foreyt and Jessup 1982; Onderka and Wishart 1988; Foreyt 1989; Foreyt 1994; Callan et al. 1991; Lawrence et al. 2010).

For example, Foreyt (1989) raised six Rocky Mountain bighorn sheep in captivity, five from birth and one that was taken from the wild as a lamb. He kept all six in captivity for 1 year. Six 
clinically normal domestic sheep were then placed on the 2 hectares of pasture with the bighorn sheep. M. haemolytica was found in swab specimens from four of the six domestic sheep but none from the bighorn sheep. All six bighorn sheep died within 4 to 71 days of exposure to the domestic sheep. $M$. haemolytica was isolated from the respiratory tract tissue of the bighorn sheep at the time of death. None of the domestic sheep were clinically ill during the study, but three of the six were later euthanized, and M. haemolytica was found in two of them.

A recent pen experiment definitively demonstrated a case in which a deadly pathogen was transferred from domestic sheep to bighorn sheep (Lawrence et al. 2010). Four isolates of $M$. haemolytica were obtained from domestic sheep and were tagged with a plasmid carrying genes for a green fluorescent protein and for resistance to the antibiotic ampicillin. The tagged bacteria were put back into four domestic sheep, who then entered a pen experiment with four bighorn sheep. The bighorn sheep all contracted pneumonia and died. More informatively, tagged bacteria, which glowed green and grew even in the presence of ampicillin, were found in all four bighorn sheep. The study shows unambiguously that transmission of $M$. haemolytica from domestic sheep to bighorn sheep occurs and that it can result in pneumonia and death of the bighorn sheep.

Comingling of domestic and bighorn sheep under experimental conditions clearly results in transmission of fatal pneumonia to bighorn sheep. However, pen experiments do not completely account $\mathrm{t}$ for the transmission of fatal disease between domestic sheep and bighorn sheep in the wild but does provide evidence that comingling could result in fatal pneumonia to bighorn sheep.

\section{Observations of outbreaks following contact between domestic and free- ranging bighorn sheep}

Since the early 1980s, there have been anecdotal field reports of bighorn deaths due to pneumonia following contact with domestic sheep (Foreyt and Jessup 1982; Coggins 1988; George et al. 2008). Given the evidence from pen experiments, it is likely that transmission of pneumophilic bacteria could also occur in which inhalation of the bacteria can infect alveolar macrophages and could also occur in the wild. Bighorn sheep and domestic sheep are attracted to each other, particularly during rut, which increases the probability that they will make the close contact necessary for disease transmission when they are in the vicinity of one another (Onderka et al. 1988; Foreyt 1989; Ward et al. 1997; Dubay et al. 2002).

Evidence that disease transmission and subsequent die-offs may occur in the wild comes from numerous observations of bighorn sheep die-offs following contact between free-ranging bighorn sheep wand domestic livestock (e.g., Onderka and Wishart 1984; Coggins 1988; Callan et al. 1991; George et al. 2008). Onderka and Wishart (1984) describe a major die-off of bighorn that began in southeastern British Columbia after bighorn sheep were observed mixing with domestic sheep and proceeded to spread south over the course of three winters, eventually reaching Glacier National Park. Coggins (1988) reports a die-off that killed two-thirds of a herd of 100 animals in the Wallowa Mountains in northeastern Oregon. Almost 2 months before the outbreak, two bighorn rams and a ewe had been observed with a domestic ewe. In December 1997, on Sugarloaf Mountain in Colorado, George and others (2008) observed a single domestic ram grazing with a group of bighorn sheep, 8.70 miles ( 14 kilometers) from the nearest herd of 
domestic sheep. It was the first and only time during a 10-year study that the authors saw domestic sheep associating with bighorn sheep, and it coincided with the beginning of an outbreak that eventually spread to two additional herds.

These observations and others like them (Martin et al. 1996) are consistent with the hypothesis that disease spread by domestic sheep cause die-offs of bighorn sheep herds, but they are by themselves essentially anecdotal. On the one hand, they do not include definitive evidence that transmission of a fatal pathogen occurred - evidence that is only possible in a carefully controlled experimental setting. On the other hand, they lack generality - even if disease transmission has occurred in one or a few cases, no real proof exists that domestic sheep transmitted a fatal pathogen and is it really just a natural phenomenon?

\section{Analyses Correlating Bighorn Population Performance with Distance from Domestic Sheep}

The few attempts to quantitatively test whether contact with domestic sheep poses a general risk of die-off or extirpation of bighorn sheep populations have examined the correlation between population performance and distance from domestic sheep. Monello and others (2001) analyzed population records of 99 bighorn sheep herds ranging from the southwestern United States to Alaska, in an investigation designed to discover the ecological correlation of pneumonia epizootics. They found that bighorn sheep populations that had suffered a pneumonia-induced die-off were located, on average, significantly closer to domestic sheep allotments ( $14.97 \pm 7.15$ miles than either those that had not suffered a die-off ( $24.61 \pm 5.28$ miles) or those that had suffered a die-off not induced by pneumonia.

Singer and others (2000d) analyzed factors contributing to the success of 100 translocations of bighorn sheep in 6 western states and found that the 30 unsuccessful translocations were, on average, significantly closer to domestic sheep $(3.73 \pm$ miles $)$ than either modestly successful or successful translocations. Finally, based on an analysis of 24 herds, Singer and others (2001) found that the persistence of bighorn sheep populations was significantly correlated with the presence of domestic sheep: populations located closer to domestic sheep were smaller and had lower population growth rates than bighorn populations located farther from domestic sheep.

While these analyses indicate that bighorn sheep populations perform more poorly when they are closer to domestic sheep, they typically do not include observations of contact or direct evidence of transmission of a pathogen from domestic sheep to bighorn sheep.

\section{Disease Summary}

Besser and others (2012a) identified that epizootic pneumonia of bighorn sheep is a devastating disease and etiology regarding the bacterial respiratory pathogens is unclear. To help clarify the etiology, Besser and others (2012a) used culture and culture-independent methods to compare the prevalence of the bacterial respiratory pathogens in lung tissue from 44 bighorn sheep from herds affected by 8 outbreaks. Mannheimia haemolytica, was the only agent detected at significantly higher prevalence in animals from outbreaks ( 95 percent) than in animals from unaffected healthy populations ( 0 percent) and the other respiratory pathogens were frequently 
but inconsistently detected (Besser et al. 2012a). Transmission of Mannheimia haemolytica from domestic sheep to bighorn sheep was irrefutable, as demonstrated by Lawrence and others (2010), and provides justification sufficient for preventing range overlap and potential association of domestic sheep and goats with bighorn sheep (WAFWA 2012).

It is true that no one form of evidence can conclusively demonstrate that contact with domestic sheep frequently leads to die-offs off bighorn sheep populations in the wild. Taken together, however, the experiments and observations from the lab and the field do indicate that contact of wild bighorn populations with domestic sheep does pose a risk of disease transmission and dieoffs in free-ranging bighorn populations. Lab experiments demonstrate the particular sensitivity of bighorn sheep to some pneumonia-causing bacteria. The controlled conditions available in inoculation and pen experiments show that healthy domestic sheep often carry bacteria that are fatal to bighorn sheep, and that they can transmit those bacteria through close contact. Finally, nearly a century of observations in the field supports the view that proximity to domestic sheep is a risk factor for bighorn sheep, possibly due in part to disease transmission from domestic sheep to bighorn sheep.

Garde and others (2005) offers the following conclusions summarizing the risk to wild bighorn sheep from Pasteurella spp. and Mannheimia spp.

- These bacteria can cause pneumonia in bighorn sheep, but there are benign commensal strains in the upper respiratory tract which have no harmful effects.

- Pathogens that are benign in domestic sheep can be lethal in bighorn sheep.

- The transference of pathogens from domestic to bighorn sheep has been documented in laboratory settings with resulting mortality in bighorn sheep.

- Domestic sheep, goats, and llamas have been reported with these bacteria species.

- Wild sheep and mountain goats have been reported with these bacteria species.

- Transmission is by direct contact and aerosolization (e.g., fine mist from breathing).

- These bacteria species do not persist in the environment.

- Acute-to-chronic die-offs in bighorn sheep can result in low-to-100 percent mortality, although they can be present in healthy sheep.

- These bacteria are considered opportunistic and can result in pneumonia outbreaks.

- These bacteria can cause clinical disease in domestic sheep and goats but are rarely primary pathogens.

In summary, field observations suggest that bighorn sheep have a high probability of contracting fatal pneumonia following contact with domestic sheep, which has led to numerous independent experiments. These experiments provide strong corroboration that bighorn sheep have a high probability of contracting fatal pneumonia following contact with domestic sheep.

The impact of disease on bighorn sheep conservation is likely to increase as habitat loss and fragmentation restrict their movement and concentrate them into smaller areas, increasing contact rates and the spread of disease (Scott 1988; Levins et al. 1994; Schrag and Wiener 1995). 
Several agencies and experts have weighed in on the issue. Biologists with the U.S. Department of Agriculture (USDA) Forest Service Region 2 identified that the risk of disease outbreaks resulting from contact with domestic sheep and goats is the most significant threat facing bighorn sheep in both Region 2 and across their range, followed by lack of connectivity and/or loss of genetic fitness due to habitat fragmentation, habitat loss, human disturbance, competition with domestic livestock, and predation on small, isolated herds (Beecham et al. 2007). Given the substantial concern raised in the published literature over the past 30 years, management guidance has focused on the separation of these species to prevent disease transmission from domestic sheep to bighorn sheep.

\section{Other Factors/Stressors}

Recent research suggests that the interaction of disease outbreaks with other stressors (both disease and otherwise) in bighorn sheep populations is poorly understood. Miller and others (2012) considered direct and indirect causes of bighorn sheep mortality and potential interactions among proposed environmental, host, and agent determinants of disease. Miller and others (2012) reviewed hypothesized determinants associated with bighorn sheep field outbreaks concluded that a clear, invariant relationship between a single agent and field outbreaks, and has not yet been documented. Recent research (Tomassini et al. 2009; Dassanayake et al. 2010; and Lawrence et al. 2010) suggests the complex interactions of disease agents themselves increases uncertainty in diagnosis and may also predispose bighorn sheep to secondary disease events. For example, Tomassini and others (2009) suggests that pathogens typically associated with bighorn sheep mortality are secondary pathogens, indicating that there are likely other pathogens involved in primary infections that have yet to be identified. Dassanayake and others (2010) found in laboratory tests that Bibersteinia trelahosi would overgrow and inhibit M. haemolytica, suggesting the difficulty in isolating the latter in wildland disease investigations. This may be why routine isolation of Pasteurella spp. and Mannheimia spp. in wildland environments is uncommon (Foreyt 1989). Additional research is needed on the interactions of disease pathogens, but it is reasonable to expect that these factors potentially predispose bighorn sheep to diseases caused by multiple pathogens that result in multiple disease cycles (e.g., Mycoplasma ovipneumoniae, viruses, internal and external parasites, and other bacterial taxa). Some combination of disease agents with other stressors may cause the organism to shift from being commensal to pathogenic (Srikumaran 2007). Although the exact mechanism for developing pneumonia and other diseases in bighorn sheep following association with domestic sheep is unknown, experimental and field data indicate the two species are not compatible on the same ranges (Foreyt 1992a, b).

Additional stressors include: overcrowding on limited range, loss of escape cover, harassment by dogs, encroachment by humans, heavy snowfall and other weather stressors (Bunch et al. 1999), parasitism, poor nutrition, predation, and other human disturbances such as roads, habitat degradation, noise, genetics, high population densities, capture and restraint techniques, breeding behavior, the presence of other wildlife, and high dust levels (Festa-Bianchet 1988; Jenkins et al. 2000; Jones and Worley 1994; Foreyt 1998; Monello et al. 2001). These stressors may reduce the ability of bighorn sheep to resist disease (Garde et al. 2005). 
To test the possibility that it is only the stress of being housed with other animals, not the transmission of pathogens that causes bighorn sheep to fall ill, researchers have conducted pen experiments in which bighorn sheep are co-housed with other animals. Of 46 bighorn sheep in three studies, housed with elk, deer, mountain goats, llamas, cattle, horses, and steers, only two died of pneumonia (Foreyt 1992b; Foreyt et al. 1994; Foreyt and Lagerquist 1996; Besser et al. $2012 \mathrm{~b}$ ). These studies provide evidence that stress is not the sole factor causing disease in bighorn sheep when they are penned with domestic sheep. Current modeled bighorn sheep habitat suggests that the Hells Canyon Lower Salmon River population management units (PMU) could support more bighorn than current population levels (IDFG 2010). However, within the Lower Salmon River PMU there are limitation based on specific habitat needs such as lambing and wintering habitat and further refinement of habitat models and available habitat will likely reduce the estimate of potential population size (IDFG 2010). Within the Hells Canyon PMU there is extensive lambing and year round habitat but further refinement of habitat models could reduce or increase estimates of available habitat and potential population size (IDFG 2010).

Respiratory disease resulting in pneumonia is the most serious disease, population level risk when bighorn sheep share ranges with, domestic sheep; in addition, other diseases and parasites, including but not limited to scabies, anaplasma, babesia, ovine parapox (contagious ecthyma), and infectious keratoconjunctivitis (pink eye), may be communicable (Jessup and Boyce 1993).

\section{Uncertainties Identified Regarding Disease Transmission}

There are scientists and others, primarily from agricultural disciplines, who contend that disease transmission between bighorn sheep and domestic sheep is not a relevant factor in bighorn sheep distribution and population declines. The following contentions and comments were received during the public scoping process and public meetings held during the planning process of completing the Payette FSEIS (USFS 2010a) for domestic sheep allotments and bighorn sheep viability and similar concerns have been identified for the BLM planning and analysis process:

- The mechanisms and causal agents leading to epizootic disease events in bighorn sheep are not completely understood.

- The hypothesis that bighorn sheep have a high likelihood of contracting fatal respiratory disease following contact with domestic sheep has not been scientifically demonstrated in wildland conditions.

- Bighorn sheep die-offs have occurred in the absence of domestic sheep.

- Sources of error or omission and data limitations have not been presented by those advocating that disease transmission does occur between the species.

- The peer review process does not support the contention that disease transmission occurs between the species.

- Research evaluating disease transmission between the species lacks proper experimental design that is not accounted for in the results. 
- Current, ambient levels of pathogens occur in bighorn sheep, regardless of how those pathogens were introduced, making separation from domestic sheep irrelevant.

- Given the probabilities of contact from off-federal private lands sources, excluding domestic sheep on federal lands is futile.

Ward and others (1997) could not conclusively attribute a bighorn sheep die-off in Nevada to disease transmission, although he did note that the die-off occurred after domestic sheep were detected on those ranges. The study did find Pasteurella spp. isolates in both species and suggests a disease transmission event. They further advise separation of the species given the propensity for contact and disease transmission.

Miller and others (2012) identified that a clear, invariant relationship between a single agent and field outbreaks has not yet been documented, in part due to methodological limitations and practical challenges associated with developing rigorous study designs. Miller and others (2012) identified a need to develop predictive models for outbreaks and validated mitigation strategies, as uncertainty remains as to whether outbreaks are due to endemic or recently introduced agents.

We have learned a tremendous amount from recent research on pathogen transfer between the species, and the fact that some pathogens that are non-lethal in domestic sheep have high lethality in bighorn sheep (Dassanayake et al. 2009). We also know that specific pathogens are transmitted from domestic sheep to bighorn sheep, resulting in bighorn sheep mortality (Lawrence et al. 2010; Besser et al. 2012a).

As discussed above, uncertainties regarding disease transmission have been identified, and specifically where findings very clearly infer disease transmission between the species, citing improper experimental design or other flaws in research design. However, the referenced papers have been published in widely recognized scientific publications and have undergone rigorous peer review prior to publication (USFS 2010b). The Wild Sheep Working Group (WAFWA 2012) identified that since the cause of the start of a disease outbreak is unknown that separation is the most prudent action to take.

Some contend a lack of evidence of disease transmission between domestic sheep and bighorn sheep in wildland environments. Much of the evidence is circumstantial; however, the compilation of cases throughout several decades contributes to an increasing body of evidence that overwhelmingly demonstrates bighorn sheep near domestic sheep are at risk for disease transmission, even though contact may not have actually been observed. Monello and others (2001) states that bighorn sheep herds classified in a pneumonia-induced die-off category were located significantly closer (less than 15 miles) to domestic sheep allotments than those in a nondie-off category (more than 25 miles). George and others (2008) document a winter die-off in Colorado that affected three bighorn sheep herds that was traced to contact with a single domestic ewe.

Additional arguments state that since disease pathogens have already been transferred to domestic sheep, separation at this point is moot, or that private lands provide risks to bighorn sheep that cannot be offset, regardless of actions taken on federal lands (USFS 2010b). These contentions claim that management on federal lands to provide separation will not be effective due to changed conditions that cannot be offset. The uncertainty in these contentions poses all of 
the risk to be borne by bighorn sheep. They do not consider that pathogens likely evolve as they move within and between species, or existing or new diseases that are virulent to bighorn sheep (e.g., mycoplasms) may still be transferred between domestic and bighorn sheep. Recent serological research (Dassanayake et al. 2009) demonstrates that pathogens, in this case Mannheimia haemolytica serotype A1, which are not lethal to domestic sheep, are transferrable to bighorn sheep and are highly lethal to them. In another recent experiment, pathogens were tagged and followed as they passed from domestic to bighorn sheep and resulted in bighorn sheep mortality (Lawrence et al. 2010).

The disease review sections of this document consider a large body of peer-reviewed and published literature, spanning several decades, that addresses the allegations. While there are gaps in the knowledge base on the causal factors and mechanisms of bighorn sheep die-offs and disease transmission between these species, the vast majority of literature supports the potential for disease transmission between the species, documents bighorn sheep die-offs near domestic sheep, and supports the management option of keeping these species separate to prevent disease transmission (WAFWA 2012; Wehausen et al. 2011). Further, there is no peer-reviewed literature that suggests bighorn sheep can be grazed with domestic sheep without concern for disease transmission between the species (Wehausen et al. 2011). Lawrence and others (2010) provided research documentation that Mannheimia haemolytica was irrefutably transferred from domestic sheep to bighorn sheep and provides sufficient justification to prevent range overlap and potential association of domestic sheep and goats with wild sheep (WAFWA 2012). Scientists from both sides of the issue also recommend that the species be kept separate until the disease transmission science is better-understood (USFS 2010b; Foreyt 1994; Foreyt et al. 1994). 
This page intentionally left blank. 


\section{Appendix B - Model Analysis Details}


This page intentionally left blank. 
This appendix contains detailed information about the three types of models used in this analysis: source habitat, probability and distance that a foraying bighorn sheep leaves its CHHR, and the predicted contacts that a bighorn sheep will have after leaving a CHHR and intersects a domestic sheep allotment.

\section{Source Habitat Model}

Bighorn sheep occupy rugged canyons, foothills, and mountainous terrain at elevations ranging from 1,450 to 10,500 feet. Key habitat features include steep, rugged escape terrain, grasses and forbs for forage, and a limited amount of tall vegetation. Native bunchgrasses and forbs are important components of forage (IDFG 2005).

Visibility is an important habitat variable for bighorn sheep - vegetation height and structure are probably more important than plant species composition for predator detection (Risenhoover and Bailey 1985; Wakelyn 1987), and a negative correlation between forest cover and bighorn sheep occurrence has been observed (Bentz and Woodard 1988). Open habitat provides good visibility for detecting predators and communicating with other herd members (Risenhoover et al. 1988). Post-fire habitats can benefit bighorn sheep by improving forage quality (McWhirter et al. 1992) and increasing visibility (Bentz and Woodard 1988). Seasonal use of different slopes and aspects results in the use of a mosaic of plant communities and phenological patterns, providing foraging and security opportunities for bighorn sheep (Valdez and Krausman 1999).

Source habitats are those characteristics of macrovegetation that contribute to positive population growth for a species in a specified area and time (Wisdom et al. 2000; Raphael et al. 2001). Source habitats contribute to source environments, which represent the composite of all environmental conditions that result in stationary or positive population growth in a specified area and within a specified time (Wisdom et al. 2000; Raphael et al. 2001). Wisdom and others (2000) describe source habitats for bighorn sheep in alpine, subalpine, upland shrubland, and upland herbland community groups. Alpine and subalpine community groups are primarily summer range, while upland herbland and shrubland are used in both seasons, depending on elevation (Wisdom et al. 2000). Old-forest and stand initiation stages of whitebark pine and the stand initiation stages of other forested cover types are other contributors to source habitat.

Escape terrain is so critical for ewes during lambing (Blood 1961; Kornet 1978; Hall 1981) that they will sacrifice access to high-quality forage for security (Festa-Bianchet 1989; Cook 1990; Bleich et al. 1997). Escape terrain must contain the following characteristics (HCBSRC 2004):

- 300 meter $^{2}$ buffer of all areas with a slope between 31 and 85 degrees

- If two or more pieces of escape terrain are within 1,000 meters (m), they are buffered so that their total area is connected

- An area of least 1.6 hectares

Source habitat for bighorn sheep occurs within BLM domestic sheep allotments and adjacent landscape. Although impacts to habitat from historic livestock grazing have been substantially reduced under current practices, livestock grazing can still cause localized areas of damage, including changes in understory vegetation from livestock foraging, infestations of undesirable vegetation, trampling of reproducing tree and shrub seedlings, soil erosion, and other habitat 
degradation. Currently, none of the four allotments is being grazed by domestic sheep. However, past grazing by domestic sheep has resulted in areas receiving varying levels of grazing use, which resulted in overall low to moderate localized impacts to the vegetation and soil resources within the allotments. Small and localized concentrated use areas (e.g., bedding grounds) are more prone to vegetation and soil disturbances. In summary, with the exception of space component of habitat (e.g., disease transmission), past grazing impacts to source habitats (e.g., water, forage, and security) were at low to moderate levels within localized areas.

Damage can result in the subsequent introduction and spread of invasive weeds and other nonnatives, disruption of ecological and physical processes, and changes in historic fire regimes. Bighorn sheep have been found to avoid habitats occupied by cattle (Wilson 1968; McQuivey 1978; Jones 1980; Dodd and Brady 1986; Steinkamp 1990). Overgrazing by domestic livestock reduces the overall carrying capacity of bighorn sheep range and may lead to more predation by increasing cover for predators. Succession of grassland to shrub communities may also increase competition with deer and increase cougar populations, the major predator of bighorn sheep (Beecham et al. 2007). Competition with domestic sheep and goats is considered even more serious than with cattle because of their similar preferences in forage and topography, and the higher potential for disease transmission between the species (Beecham et al. 2007). Past grazing by domestic sheep on the four allotments has not indicated any apparent competition for forage between domestic sheep and bighorn sheep, primary concern was competition for space and potential for disease transmission.

The existing vegetation layer from the national LANDFIRE layer (USGS 2010) was used to assess the current source habitat available for bighorn sheep. This information was utilized because it allows analyzing landscapes that extend beyond but include the BLM domestic sheep allotments, and can be used to address habitat connectivity issues at broader scales. The vegetative cover types used by the Hells Canyon Restoration Committee (HCBSRC 2004) and Wisdom and others (2000) were crosswalked into the LANDFIRE ecological systems (NatureServe 2004) to identify summer and winter source habitat. Winter source habitat is a subset of summer source habitat in that it encompasses only those areas below 4,500 feet on southerly aspects.

For this source habitat model, a component was added to the escape terrain to filter out areas that have the steepness but not the ruggedness that contributes to source habitat capacity. A ruggedness surface was created using an ArcGIS script (Sappington et al. 2007), and then the telemetry and observations were overlaid to create a histogram of the ruggedness with a range from 0 to 3,455 . Based on the histogram, areas with a ruggedness value of 310 or less were excluded from the map of source habitat capacity to limit over-mapping. Vegetation is not considered a component of source habitat capacity since vegetation will vary in response to successional and disturbance processes, while escape terrain remains constant. Therefore, while source habitat capacity is constant, source habitat will vary spatially and temporally across the landscape.

This mid-scale habitat modeling may not represent finer-scale conditions. For example, not all special habitat features may be delineated and invasions by exotic plants, forage quality, and human disturbance factors may not be detectible. Changes in the patch and pattern of range mosaics have changed since historical times as fire suppression has resulted in an increased 
density of trees in formerly open stands, with a resultant loss of foraging quantity, quality, and open habitat (Wisdom et al. 2000). Fire-suppressed stands have created barriers between historical winter and summer range, preventing occupancy of the total range although each isolated range may be suitable (Wakelyn 1987). In other cases, fires have opened up forested areas and increased habitat. Mixed-lethal fire regimes may have followed historical patch and pattern, but the same may not be true for non-lethal fire regimes. Although the effects of fires within the BLM Cottonwood Field Office Management Area on bighorn sheep habitat and movement are unknown, these fires may have opened up additional movement corridors and summer habitats for bighorn sheep. Disruption of hydrological regimes from a variety of sources has also resulted in the loss of riparian vegetation in many foraging areas (Wisdom et al. 2000).

\section{Risk of Contact Model}

\section{Telemetry Data}

Telemetry and observational data for Hells Canyon were collected by the Hells Canyon Initiative and overlapped with the BLM Cottonwood Field Office Management Area (see Map 8 in Appendix D). The Hells Canyon Initiative is a tri-state coordination group that has been focused on restoring bighorn sheep populations to Hells Canyon and is comprised of the fish and wildlife agencies of Idaho, Oregon, and Washington, as well as the U.S. Forest Service, Bureau of Land Management, and other private entities. These data include more than 54,000 telemetry points, representing approximately 400 individuals from 16 Hells Canyon herds and 2 Salmon River herds. The data used for analysis were collected from March 1997 through December 2012 for Hells Canyon bighorn sheep and 2007 through 2012 for Salmon River bighorn sheep. Telemetry and observation data for the Salmon River metapopulation was collected from multiple sources. Telemetry data for the Main Salmon/South Fork Herd was collected by the Nez Perce Tribe under a cooperative study, which includes the Nez Perce Tribe, Idaho Department of Fish and Game, Nez Perce National Forest, Payette National Forest, and the BLM Cottonwood Field Office (see Map 9 in Appendix D). The rest of the observations were collected on many different dates. The Main Salmon/South Fork and Hells Canyon bighorn sheep telemetry and observation data collection is an ongoing effort and additional data is currently being collected.

These telemetry data suggest that bighorn sheep utilize habitats within and adjacent to allotments managed by the Cottonwood Field Office. Maps 8 and 9 (Appendix D) display telemetry points or observations of bighorn sheep documented on BLM domestic sheep allotments and adjacent landscapes.

Telemetry data for the Hells Canyon was collected as part of the Hells Canyon Initiative by the Idaho Department of Fish and Game (IDFG), Oregon Department of Fish and Wildlife (ODFW), and U.S. Forest Service. In any given year, approximately 150 animals have telemetry collars as part of an ongoing effort since 1997 (Map 8 in Appendix D).

Telemetry data and observations for the Salmon River metapopulations are not as extensive at the Hells Canyon data set; consequently, there is more uncertainty about the risk of contact and potential for disease transmission, which is considered relatively high based on the data collected 
to date for the BLM domestic sheep allotments occurring in the Salmon River and Little Salmon River drainages.

The IDFG, Payette National Forest, Nez Perce National Forest, BLM Cottonwood Field Office, and Nez Perce Tribe have a cooperative project (the Salmon River Bighorn Sheep Project [SRBSP]) that places telemetry collars on Salmon River bighorn sheep. Initially, 15 sheep were collared in fall 2007 and spring 2008. A total of 68 bighorn sheep (28 rams and 40 ewes) has been captured and telemetry-collared during the project duration, and 30 bighorn sheep are currently being monitored (June 2013) with active telemetry collars (Map 9 in Appendix D). This information has provided additional bighorn sheep movement data for Salmon River canyon lands and mountains and the BLM Cottonwood Field Office management area. Forested areas and large rivers, which bighorn sheep do not prefer for movement and which serve as partial barriers to bighorn sheep movement (Singer et al. 2000c), are located between bighorn sheep habitat and some of the lands leased for domestic sheep grazing. Bighorn sheep have, however, been observed swimming large rivers and have been found in locales at which they arrived via unknown routes.

Akenson and Akenson's (1992) 5-year study of bighorn sheep in the Big Creek drainage, which included observations of 12 radio-collared ewes, provides an additional source of information about bighorn sheep movements on the Payette National Forest. They observed ewes from different parts of the winter range utilizing four different drainages for lambing and three separate summer ranges, indicating a high degree of movement for this population. They also observed ewes traveling more than 50 miles in less than 3 days, and pregnant ewes swimming Big Creek during flood stage to begin spring migration. Ewes followed rock outcrops and broken open terrain, but the migration corridor also included forested ridges and a snow-covered pass (Akenson and Akenson 1992). Big Creek bighorn sheep had separate winter ranges from the Middle Fork Salmon River bighorn sheep but did share some summer range, which would increase the risk of disease transmission between populations of the Salmon River Mountains metapopulation (Akenson and Akenson 1992).

Several incidental observations show that at least some bighorn sheep in the Salmon River metapopulation reach areas far from the mapped core herd home ranges (CHHR). One bighorn ram caught in a leg-hold trap was observed near Josephine Lake (Payette National Forest Josephine Allotment). On the North Fork Lick Creek allotment (Payette National Forest), three ewes were sighted in 1 year, and the following year, two ewes were seen along the border with the Lake Fork allotment (Payette National Forest). These individuals entered the allotments when domestic sheep were present (May-October). The lack of more extensive telemetry data makes it impossible to know how frequently other bighorn sheep utilize domestic sheep allotments.

\section{Core Herd Home Range Modeling}

Home range modeling was completed using the Home Range Extension version 1.1 for ArcGIS (Rodgers et al. 2007), a software package designed for this purpose. The Home Range Extension uses a standard bivariate normal probability density function as the kernel employed to estimate the intensity with which animals use each mapped area. A kernel is essentially a small threedimensional hill placed over the location of each telemetry observation. Where many 
observations are clustered together, these hills overlap and pile up, and their total height indicates the probability of finding an animal at a given location. The width of the kernels, href, is calculated as the square root of the mean variance in $x(\operatorname{var} x)$ and $y(\operatorname{var} y)$ coordinates divided by the sixth root of the number of points (Worton 1995):

$$
\text { Href }=n \sqrt{\frac{-1 / 6}{2} \sqrt{\operatorname{var} x+\text { var } y}}
$$

This method of selecting href is widely used as a means of extrapolating from the dispersion of observed locations to the likely extent of the full home range.

This process of home range analysis was carried out for each identifiable individual within a herd for whom more than 20 telemetry points were available. All other telemetry and observation points for a herd that did not meet these criteria were excluded from the CHHR analysis but were used to verify the accuracy of the final CHHR volume contours. The results of these analyses were a collection of surface rasters, one for each animal, from which the volume contours were created.

To create an overall CHHR, the raster surfaces from the individuals were added together. Then, volume contours, known as isopleths, were created from the merged herd surface using Hawth's Analysis Tools version 3.27 Extension for ArcGIS (Beyer 2004). Isopleths are contours meant to enclose a given percentage of the telemetry observations; the 95th isopleth for example, is drawn to enclose an area in which 95 percent of the telemetry points are found. Volume contours were calculated for the 50th, 60th, 70th, 80th, 90th, and 95th isopleths, and are shown for each herd in the Appendix L of the Payette FSEIS (USFS 2010a). The CHHR is defined as the area contained within the 95th isopleth. Points beyond the 95th isopleth were considered forays and analyzed separately (described below).

\section{Foray Analysis}

The foray model analyzed how often bighorn sheep leave the CHHR, whether they travel far enough to reach an allotment, and whether they then actually intersect an allotment (i.e., rather than intersecting a different area at the same distance from the CHHR). Movement behavior estimates were formed by analyzing the same large telemetry dataset of bighorn sheep movements in Hells Canyon that was used to determine each herd's CHHR. In the Salmon River system, only one and one-half years of telemetry data from 30 individuals in the Main Salmon/South Fork herd was available. That data was useful in estimating the herd's CHHR, but not sufficient to characterize their foray behavior. As a result, modelers used the much more extensive data collected for the Hells Canyon herds to estimate the probable movement patterns of bighorn sheep in herds throughout the Payette National Forest and BLM SEIS analysis area.

The foray analysis most likely underestimates the true frequency of longer-distance forays. The reason for this underestimation is that the vast majority of the telemetry data are from standard VHF (very-high frequency) collars (rather than from GPS collars which collect and store or transmit data from everywhere an animal travels). With VHF collars, locations are determined by triangulation from a plane or boat travelling a route every few days or weeks through the areas in 
which the bighorn sheep of a herd are usually seen. The farther a bighorn sheep has travelled from its CHHR, the farther it is likely to be from the observers, and the less likely it is to be detected. There are several cases in the telemetry data where rams last observed on a foray have disappeared for a couple of months before reappearing, likely from a journey that carried them beyond the range of detection of the survey.

For bighorn sheep moving through forested areas, detection may also be hampered by line-ofsight and signal bounce issues. Finally, even when an animal on foray is detected in every survey, the large interval between observations means that it is unlikely to be observed at the furthest extent of its foray. The extent to which these forms of sampling bias underestimate the frequency of long-distance movements in the foray analysis is unknown.

The path taken by a bighorn sheep traveling outside its CHHR might intersect any part of an allotment; therefore, the analysis began by calculating the probability of intersecting an allotment within each of 35 rings or annuli, each $1 \mathrm{~km}$ wide, located between 1 and $35 \mathrm{~km}$ from the CHHR boundary. That probability was broken into two parts: probability of a foray movement, and probability that a bighorn sheep on a foray will reach a ring and intersect an allotment within that ring.

\section{Probability of a Foray Movement}

Most bighorn sheep, especially ewes, never move beyond the CHHR in most years. Map displays the maximum distance of ram forays outside of CHHR areas (95 percent isopleth) for the data set. Forays from all but one bighorn sheep were between 0 and $(26 \mathrm{~km})$; one ram had a documented foray that extended $(35 \mathrm{~km})$ from its CHHR. Foray distances were stratified into $(1 \mathrm{~km})$ concentric rings that originated from CHHR areas, and were used as a basis for calculating the probability of contact.

The frequency of foray movements by both rams and ewes in summer (May-October) and winter (November-April) are shown in Table B-1. The probability of bighorn sheep-domestic sheep contact in summer and winter were calculated separately because characteristic movement patterns differ between seasons (e.g., the rut occurs in November/December and produces relatively frequent and long-distance exploratory forays by rams), and three of the allotments are only open to domestic sheep during the summer period, and the Partridge Creek allotment has domestic sheep grazing during summer and winter periods.

According to Table B-1, 28.8 percent of radio-collared rams left the CHHR at least once (in summer) during the years they were observed. In any one summer, however, just 14.1 percent of rams left the CHHR. Accordingly, in the foray model, each ram was given a 14.1 percent probability per summer of making a foray outside of the CHHR. Similarly, ewes were given a 1.5 percent probability of leaving the CHHR each summer. 


\begin{tabular}{|c|c|c|c|c|}
\hline \multirow{2}{*}{$\begin{array}{c}\text { Table B-1: } \\
\text { Timeframe }\end{array}$} & $\begin{array}{c}\text { Percentage } \\
\text { of Animals } \\
\text { Observed }\end{array}$ & $\begin{array}{c}\text { Number out of } \\
\text { Total } \\
\text { Observations }\end{array}$ & $\begin{array}{c}\text { Percentage } \\
\text { of Animals } \\
\text { Observed }\end{array}$ & $\begin{array}{c}\text { Number out of } \\
\text { Total } \\
\text { Observations }\end{array}$ \\
\hline \multicolumn{1}{|c|}{ Summer (May-October) } & \multicolumn{3}{|c|}{ Ewes } & \multicolumn{3}{c|}{ Rams } \\
\hline Animals leaving CHHR at least once & 6.5 & $14 / 215$ & 28.8 & $30 / 104$ \\
\hline Animal-years with at least one foray & 1.5 & $15 / 985$ & 14.1 & $44 / 311$ \\
\hline Telemetry points outside of CHHR & 0.2 & $29 / 17,258$ & 4.4 & $160 / 3,674$ \\
\hline \multicolumn{1}{|c|}{ Winter (November-April) } & \multicolumn{2}{|c|}{ Ewes } & \multicolumn{3}{c|}{ Rams } \\
\hline Animals leaving CHHR at least once & 12.9 & $28 / 217$ & 34.9 & $38 / 109$ \\
\hline Animal-years with at least one foray & 5.6 & $60 / 1,062$ & 17.8 & $68 / 380$ \\
\hline Telemetry points outside of CHHR & 0.8 & $109 / 12,941$ & 3.7 & $156 / 4,200$ \\
\hline
\end{tabular}

\section{Probability that a Bighorn Sheep will Intersect an Allotment}

Many animals (particularly ewes) may not travel far, even if they are observed outside of the CHHR. The probability that a bighorn sheep on a foray will reach an allotment decreases as the travelling distance increases. Bighorn sheep rams are more mobile and leave CHHRs during summer and winter periods significantly more than ewes (see Table B-1) and have a higher probability of interspecies contact. Consequently, the discussion and graphs below are focused on foraying bighorn sheep rams. To characterize that decreasing probability, the modelers first extracted from each foray, the maximum distance from the CHHR at which an animal was observed (Figures B-1 and B-3) and then the proportion which an animal reaches each ring (Figures B-3 and B-4). In the dataset, the maximum distance was $35 \mathrm{~km}$ (summer) and $50 \mathrm{~km}$ (winter), so the model distribution extends to that distance.

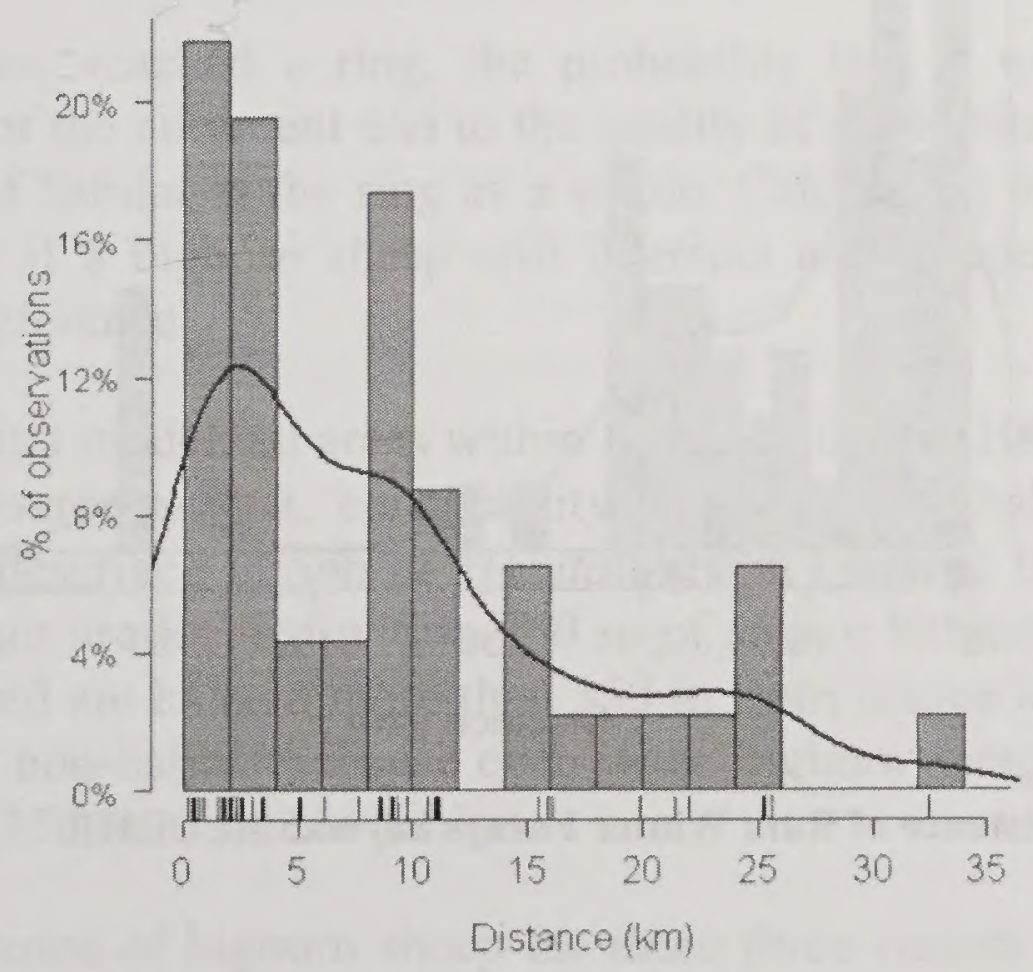

Figure B-1: Maximum Distance of Ram Summer Forays beyond the CHHR (Source: USFS 2010a) 


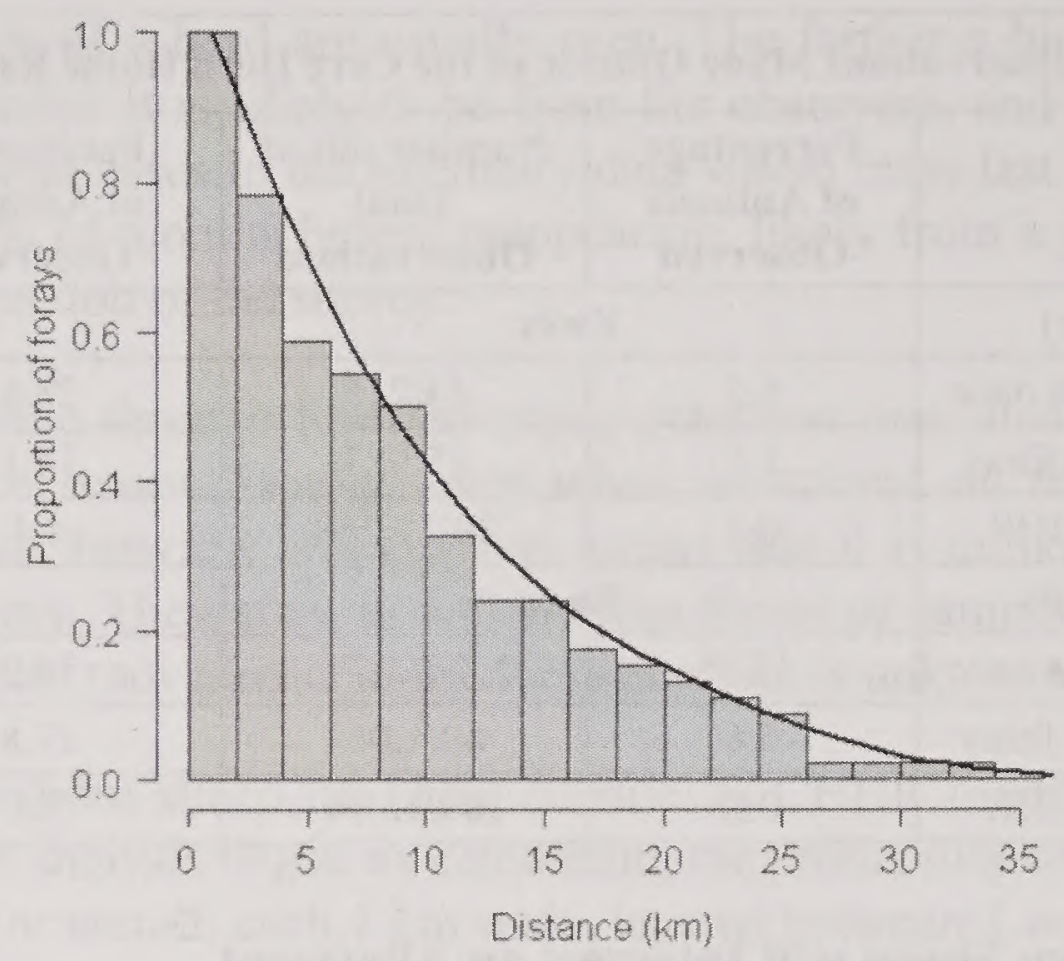

Figure B-2: $\quad$ Proportion of Ram Summer Forays Reaching Each Ring (Source: USFS 2010a)

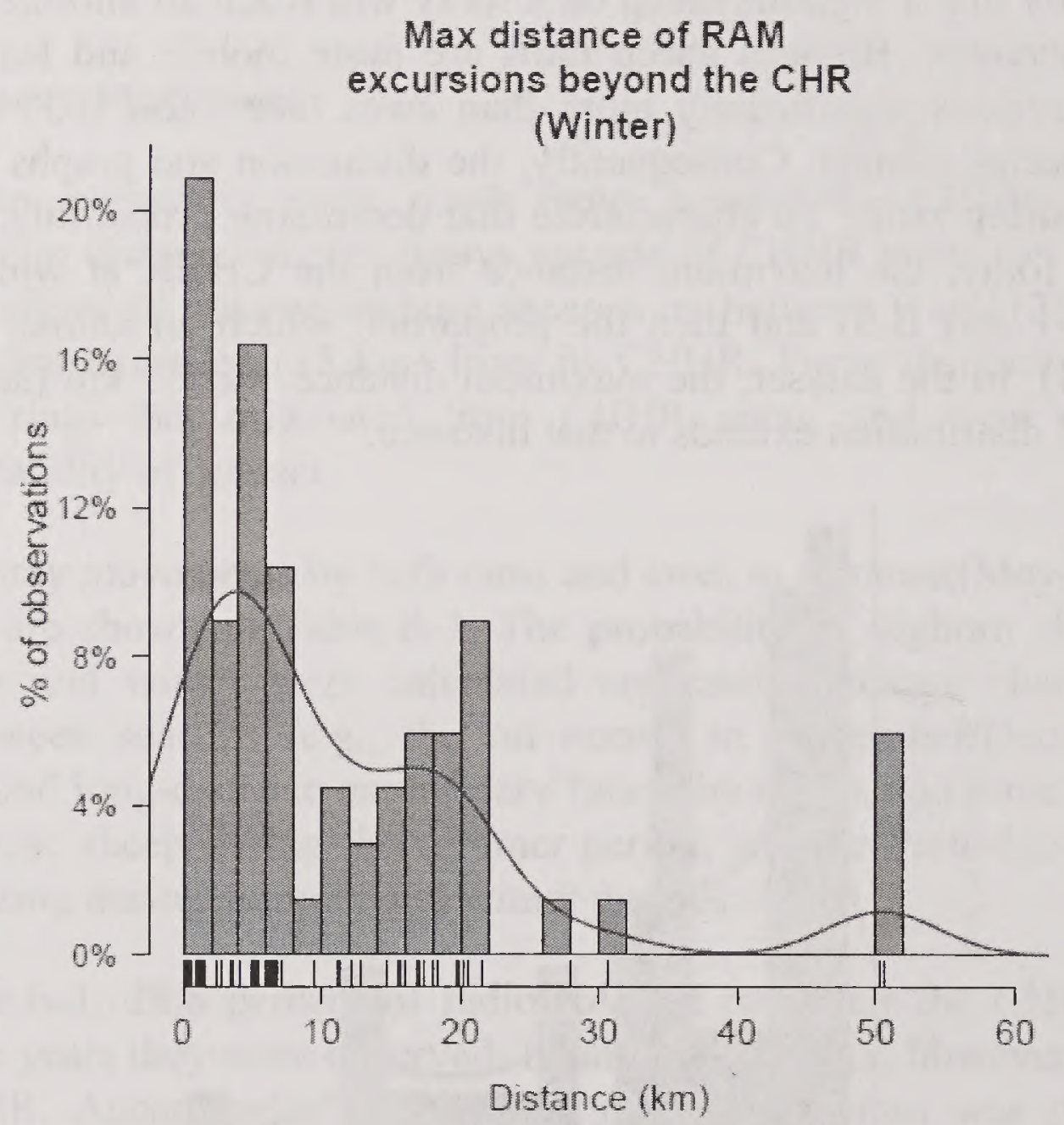

Figure B-3: $\quad$ Maximum Distance of Ram Winter Forays beyond the CHHR (Source: USFS 2010a) 


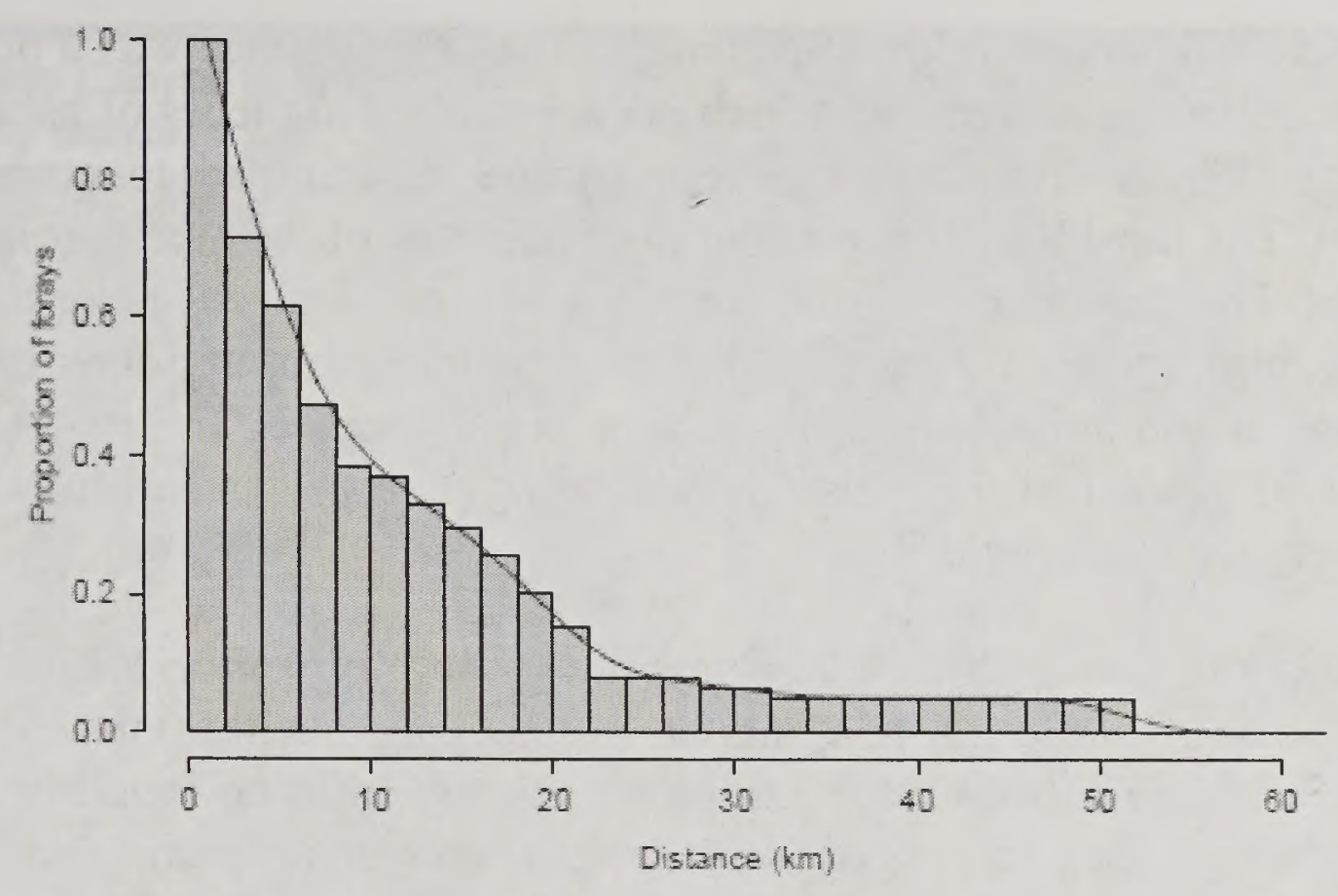

Figure B-4: $\quad$ Proportion of Ram Winter Forays Reaching Each Ring

(Source: USFS 2010a)

An animal located $25 \mathrm{~km}$ from the CHHR has crossed each ring between itself and the CHHR. In addition, 100 percent of the animals that make a foray intersect at least the first ring around the CHHR. More generally, the proportion of animals whose forays intersect each ring is equal to the proportion known to have reached it or one of the rings beyond it. Approximately half of the rams who leave the CHHR travel at least $10 \mathrm{~km}$ (summer and winter) from the CHHR and almost a quarter of the rams travel $16 \mathrm{~km}$. However, just one ram has been observed during the summer to travel more than $26 \mathrm{~km}$ and one ram during the winter was observed to travel more than $50 \mathrm{~km}$ from the CHHR. This model uses the distribution to calculate the probability that an animal will reach any given ring surrounding its CHHR, (Animal reaches ring foray).

Given that an animal has reached a ring, the probability that it will be in an allotment is proportional to the size of the allotment and to the quality of the habitat in the allotment relative to the size and quality of habitat in the ring as a whole. Calculating the size of the allotment is simple, but determining if a bighorn sheep will intersect an allotment first requires knowing bighorn sheep habitat preference.

Based on the source habitat model, all areas within $35 \mathrm{~km}$ of the CHHRs were assigned to one of three habitat classes - source habitat, connectivity area, and non-habitat. Source habitats are areas fitting the criteria described in Source Habitat Model, on page B-1. Connectivity areas do not meet those criteria but are located within $350 \mathrm{~m}$ of source habitat. Areas of non-habitat do not meet those criteria and are located more than $350 \mathrm{~m}$ from source habitat. Connectivity areas were distinguished from non-habitat because even when bighorn sheep are of source habitat, all but 80 have been within $350 \mathrm{~m}$ of source habitat.

Next, the relative preference of bighorn sheep for these three classes of habitat was calculated using a resource selection function (Manly et al. 1993, Boyce et al. 2002). The habitat classes consisted of habitat, habitat connectivity, and non-habitat. The habitat class is the same as summer source habitat. Habitat connectivity was created by using a two-stage buffer on the summer source habitat. The first stage is a simple buffer around patches of habitat at $350 \mathrm{~m}$, which was determined by measuring the distance of all telemetry data that fell outside habitat 
and finding one standard deviation of those distances. The second stage was a buffer of $1,050 \mathrm{~m}$ (three times the distance of the first stage), which is only applied to pieces of habitat connectivity that are within the $1,050 \mathrm{~m}$ distance. The second stage is designed to connect fragmented complexes of habitat. The third habitat class consists of the rest of the area that is not covered by the first two classes. The resource selection function was constructed using a use/availability approach that yields high values for habitat classes with many observations of bighorn sheep relative to their area. If the animals in a herd have equal areas of Habitat $\mathrm{A}$ and Habitat $\mathrm{B}$ available, but spend 90 percent of their time in Habitat A, their preference for Habitat A would be 9 times their preference for Habitat B.

While on forays, bighorn sheep in the Hells Canyon herds prefer source habitat to connectivity areas, and prefer both of those to non-habitat. Specifically, within the $35-\mathrm{km}$-wide ring surrounding a CHHR, bighorn sheep were 5.6 times more likely to be found in a given squarekilometer of source habitat than in a square-kilometer of connectivity area, and 35 times more likely to be found in source habitat than in non-habitat.

Finally, habitat preference and the distribution of habitat within each ring surrounding a CHHR was used to calculate the probability that a bighorn sheep that reaches a particular ring would cross the ring into an allotment. The map in Figure B-5 is a visualization of the estimated probabilities that bighorn sheep on a foray will reach each location within $35 \mathrm{~km}$ of the CHHR. Dark blues represent the highest probabilities, and light yellows the lowest. Moving outward from the CHHR, colors lighten as the probability of a foray reaching that distance drops. Within each ring, the darkest color (highest relative probability) marks areas of habitat, the lightest color (lowest relative probability) marks areas of non-habitat, and the intermediate color marks areas of connectivity habitat.

\section{Foray Analysis Results in the Context of Other Published Works}

Both the frequency and distances of foray movements by Hells Canyon bighorn sheep were consistent with other reports in the literature. Singer and others (2001) calculated annual foray rates of bighorn sheep in 10 published studies. In those herds, the annual number of forays per radio-collared animal of either sex ranged from 0 to 0.23 (mean 0.10 , standard deviation 0.09 ), comparable to 14 percent of rams and 1.5 percent of ewes making summer forays from herds in the Hells Canyon metapopulation.

In southwestern Alberta, Festa-Bianchet (1986) relocated rams as far as $48 \mathrm{~km}$ from the site of their capture. A recent 17-month study of three bighorn herds in Montana, (DeCesare and Pletscher 2006) found relatively long (19 to $33 \mathrm{~km}$ ) movements by four of five radio-collared males. Finally, Singer and others $(2000 \mathrm{c})$ followed 31 translocated populations of bighorn, and documented numerous colonizations of nearby patches of habitat. In that study, the probability of colonization (75 percent) was highest for patches located $12.3 \mathrm{~km}$ from a bighorn sheep population indicating that such movements occur with relatively high frequency. This parallels our finding that nearly 25 percent of forays by Hells Canyon bighorn sheep reach a distance of at least $15 \mathrm{~km}$ from the CHHR. 


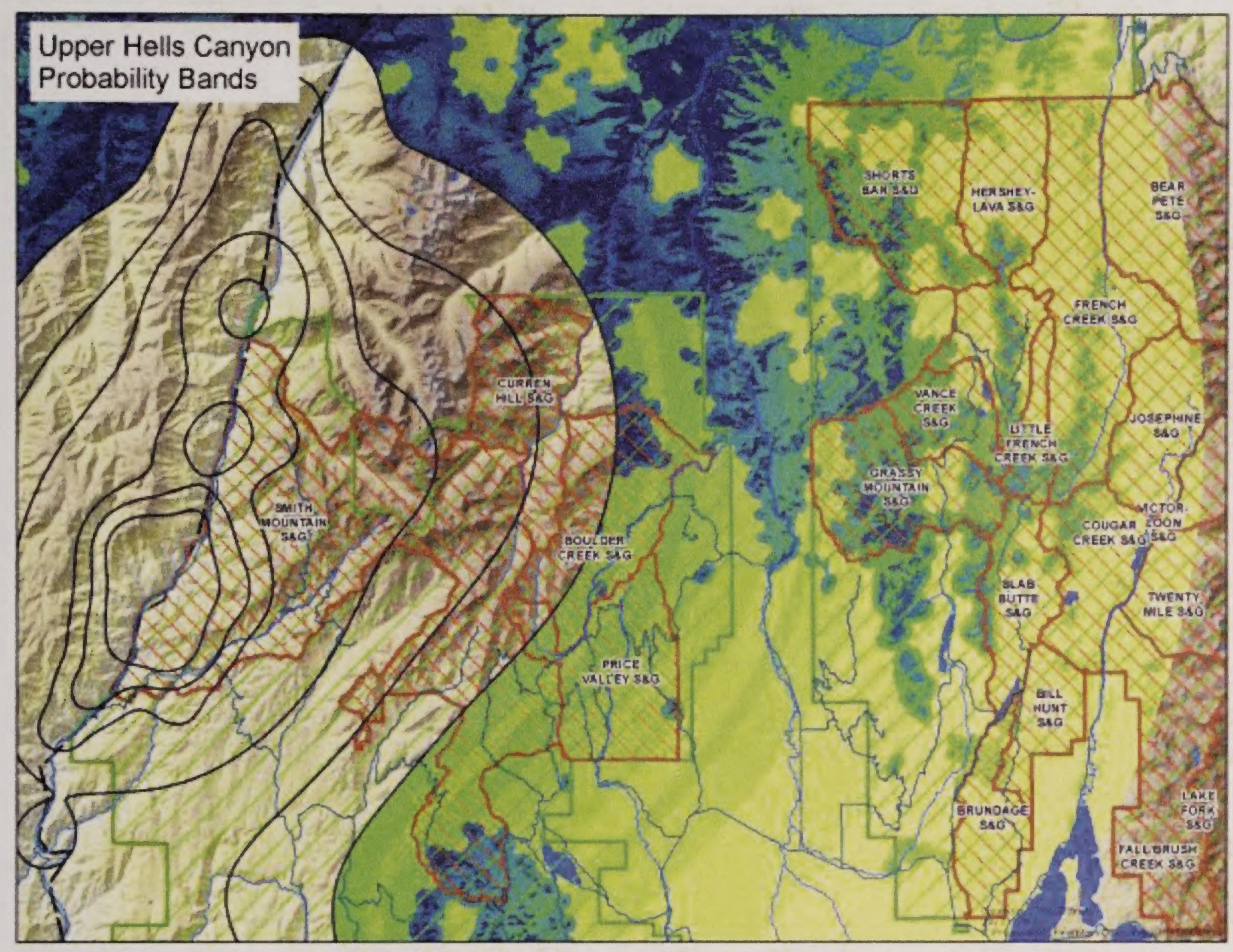

Figure B-5: Visualization of Foray Probabilities for the Upper Hells Canyon Herd (Source: USFS 2010a) 
This page intentionally left blank. 


\section{Appendix C - Domestic Sheep and Goats Grazing Lease Terms and Conditions}


This page intentionally left blank. 


\section{Domestic Sheep and Goats Grazing Lease Terms and Conditions}

1. Immediately report incidents of interspecies contacts to IDFG and BLM . Immediately initiate actions to remove co-mingling bighorn sheep with IDFG or other authorized party in accord with approved plan and protocol.

2. Count domestic sheep onto the allotments at the start of the grazing season, and off the allotment at the end of the season. Periodically during the grazing season count as needed to determine if strays or small groups moved off from the main band.

3. Maintain an appropriate ratio of marker sheep within bands; depending on local needs and conditions, ratios should be no less than 1 marker for every 50 adult sheep. More markers may be required when dictated by local conditions.

4. Count marker sheep on a regular basis, immediately any time sheep scatter and at a minimum count marker sheep twice a day (e.g., mid-day and when bedded).

5. Place bells on at least 1 in every 100 mature ewes to serve as warning, and for identification and location sheep relative to other sheep.

6. When domestic sheep are difficult to observe because of dense vegetation or in steep and rugged terrain, always count marker sheep after emerging from such conditions.

7. Increase sheepherder monitoring (minimum two patrols around band, at least 4-hours apart) on bright moonlit nights because sheep may be more prone to rise and graze under these conditions.

8. Develop a strategy for reporting, searching, and quick recovery of stray domestic sheep.

9. Equip herders will be equipped with binoculars, radios, phones (cell and/or satellite) or other communication response measures.

10. Herders will have firearms, which may be used for hazing of bighorn sheep or predator control.

11. Use a minimum of one mature and effective guard dog, and two mature and effective herding dogs per domestic sheep band.

12. Use propane (Zon) guns to haze bighorn sheep.

13. Remove sick or physically infirmed domestic sheep from the band. Remove all sheep that are unable to keep with the band, regardless of reason, from the allotment.

14. Immediately locate and gather strays when predator attacks occur, and document domestic sheep that were killed.

15. Require close bedding (5-acres or less) of domestic sheep at night, some areas designated for bedding may include fenced (temporary or electric) areas for increased control and monitoring. 
16. Require sheepherders to use a log book or other record keeping aids to report GPS locations, predator incidents, straying incidents, recovery efforts for stray domestic sheep, bighorn sheep sightings, domestic sheep counts, and other information as needed or required. This information will be made available to BLM personnel upon request periodically during grazing season and the $\log$ book will be submitted to the Cottonwood $\mathrm{FO}$ at the end of the grazing season. 
Appendix D - Maps 
This page intentionally left blank. 
Map 1: Hells Canyon and Salmon River Bighorn Sheep Metapopulations and BLM Domestic Sheep Allotments

Map 2: BLM Domestic Sheep Allotments

Map 3: Domestic Sheep Allotments, Summer Core Herd Home Ranges, and IDFG Big Game Management Units

Map 4: Domestic Sheep Allotments, Winter Core Herd Home Ranges, and IDFG Big Game Management Units

Map 5: BLM Domestic Sheep Allotments and Alternatives

Map 6: Bighorn Sheep Summer Source Habitat

Map 7: Bighorn Winter Source Habitat

Map 8: Bighorn Sheep Telemetry and Observation Locations within Analysis Area

Map 9: Forest Service, BLM, Private, and State Domestic Sheep Allotments

Map 10: Payette National Forest Plan Amendment 
This page intentionally left blank. 


\section{Map 1 \\ Hells Canyon and Salmon River Bighorn Sheep Metapopulations and BLM Domestic Sheep Allotments}
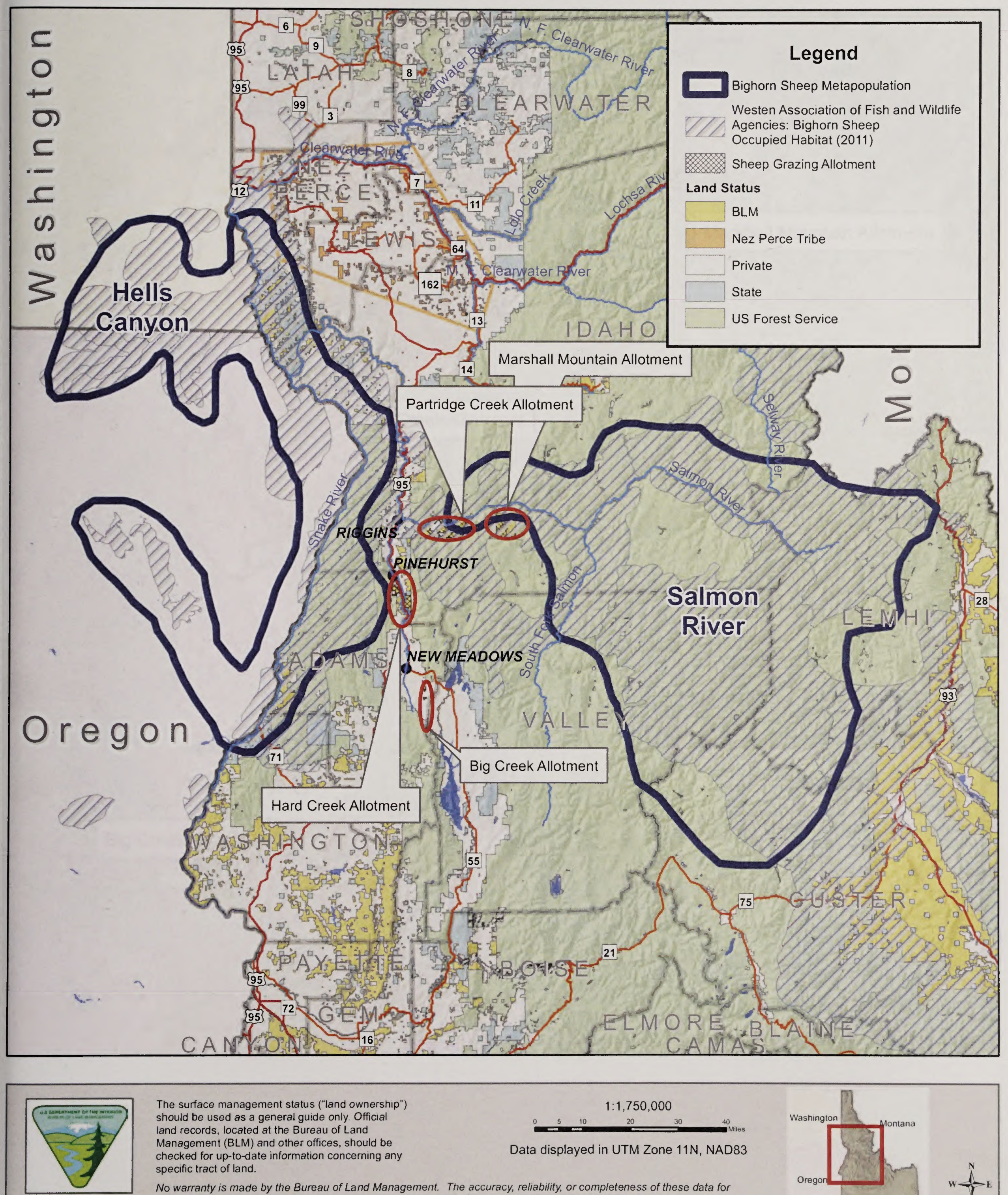

The surface management status ("land ownership")

should be used as a general guide only. Official

land records, located at the Bureau of Land

Management (BLM) and other offices, should be

checked for up-to-date information concerning any

specific tract of land.

$1: 1,750,000$

No warranty is made by the Bureau of Land Management. The accuracy, reliability, or completeness of these data for

individual use or aggregate use with other data is not guaranteed. The following cannot be made Section 508 compliant

Map Created: 10/27/2011 For help with its data or information, please contact the BLM Idaho State Office Webmaster at 208-373-4000. 



\section{BLM Domestic Sheep Allotments}

Map 2

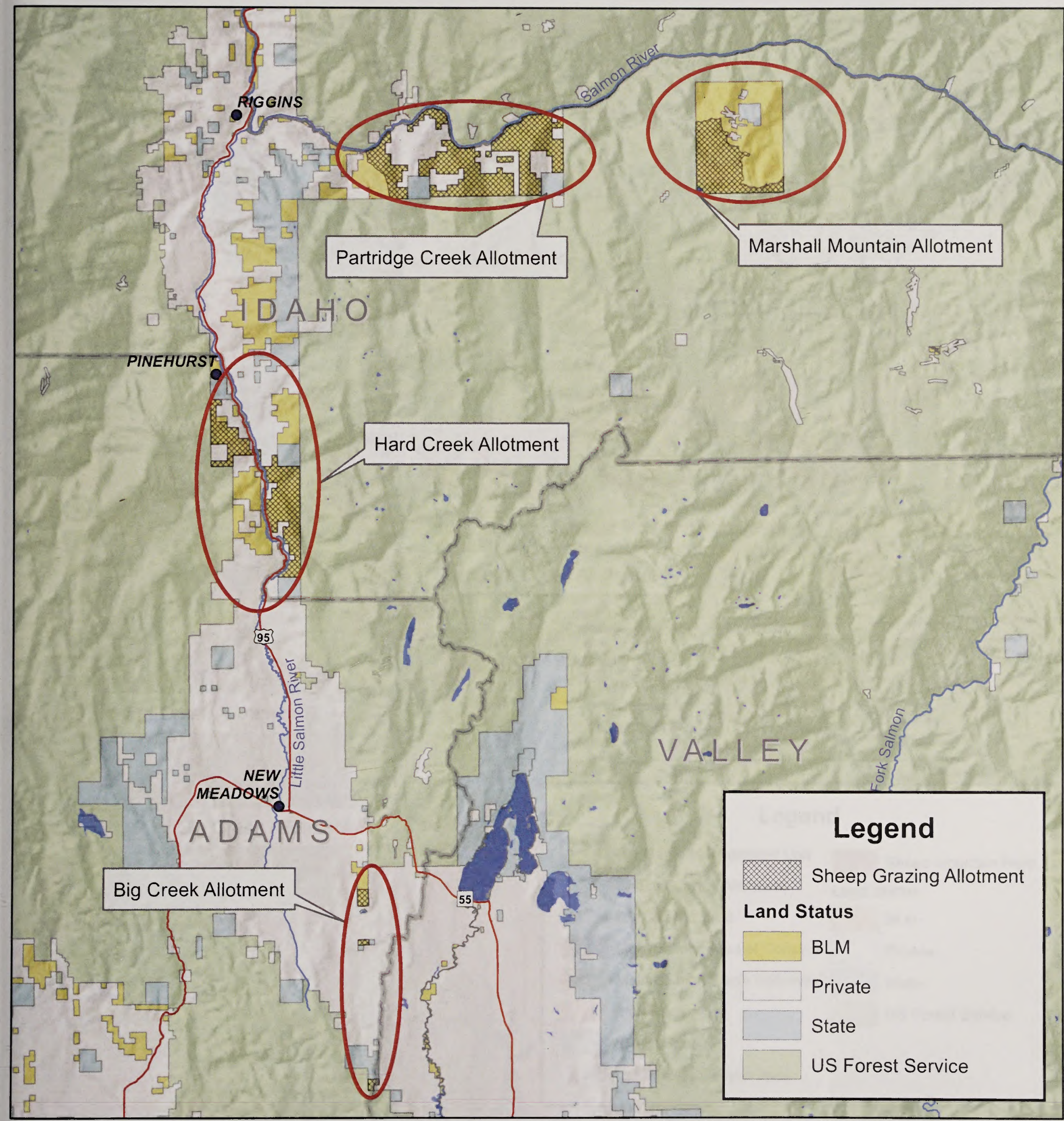

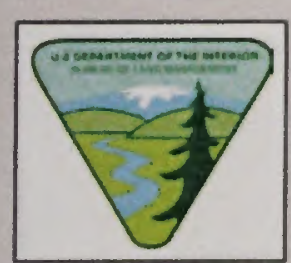

The surface management status ("land ownership") should be used as a general guide only. Official land records, located at the Bureau of Land

Management (BLM) and other offices, should be

checked for up-to-date information concerning any

specific tract of land.

No warranty is made by the Bureau of Land Management. The accuracy, reliability, or completeness of these data for

individual use or aggregate use with other data is not guaranteed. The following cannot be made Section 508 compliant

Map Created: 10/27/2011 For help with its data or information, please contact the BLM Idaho State Office Webmaster at 208-373-4000.

\section{$1: 400,000$}

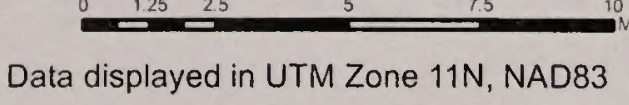

Data displayed in UTM Zone $11 \mathrm{~N}$, NAD83 (n) 


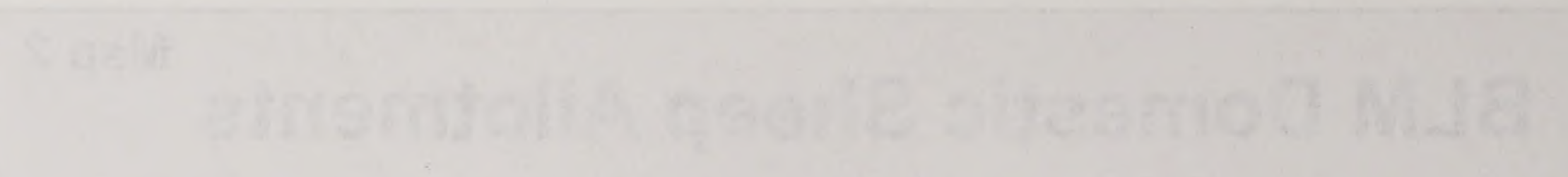




\section{Domestic Sheep Allotments, Summer Core Herd Home Ranges, and IDFG Big Game Management Units \\ Map 3}
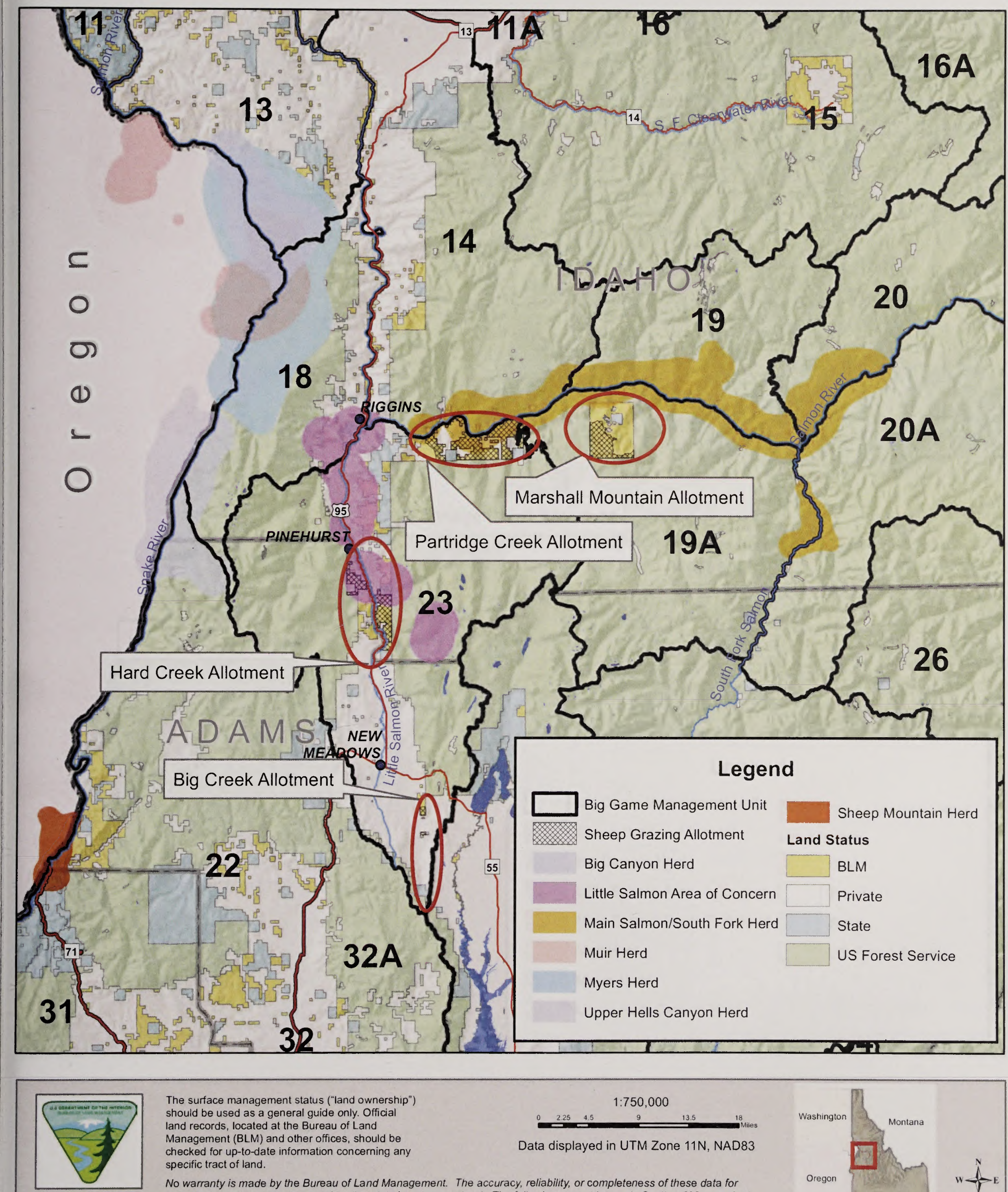

The surface management status ("land ownership")

should be used as a general guide only. Official

land records, located at the Bureau of Land

Management (BLM) and other offices, should be

checked for up-to-date information concerning any

specific tract of land.

No warranty is made by the Bureau of Land Management. The accuracy, reliability, or completeness of these data for

individual use or aggregate use with other data is not guaranteed. The following cannot be made Section 508 compliant.

Map Created. 10/27/2011 For help with its data or information, please contact the BLM Idaho State Office Webmaster at 208-373-4000. 

Domestic Sheep Allotments, Winter Core Herd

Map 4 Home Ranges, and IDFG Big Game Management Units
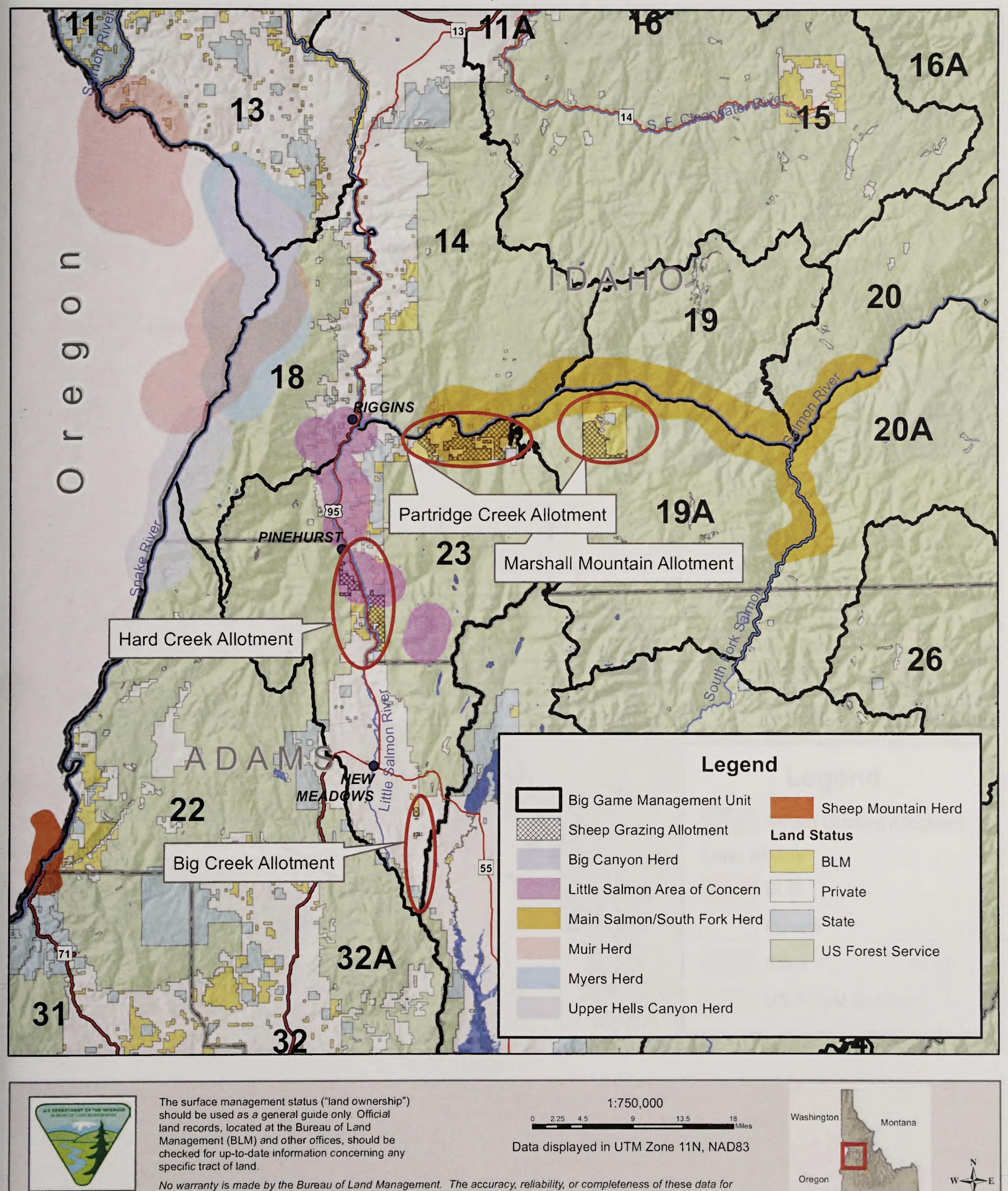

The surface management status ("land ownership") should be used as a general guide only. Official land records, located at the Bureau of Land

Management (BLM) and other offices, should be

checked for up-to-date information concerning any specific tract of land.

No warranty is made by the Bureau of Land Management. The accuracy, reliability, or completeness of these data for individual use or aggregate use with other data is not guaranteed. The following cannot be made Section 508 compliant.

\section{$1: 750,000$}

Data displayed in UTM Zone 11N, NAD83

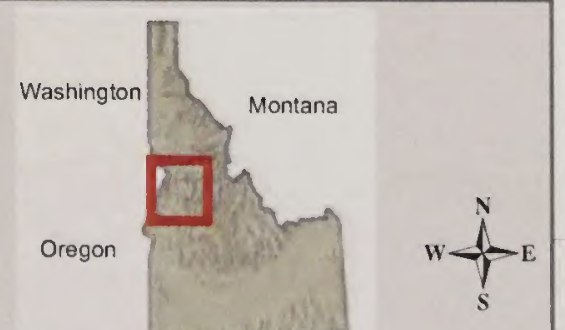





\section{BLM Domestic Sheep Allotments and Alternatives}
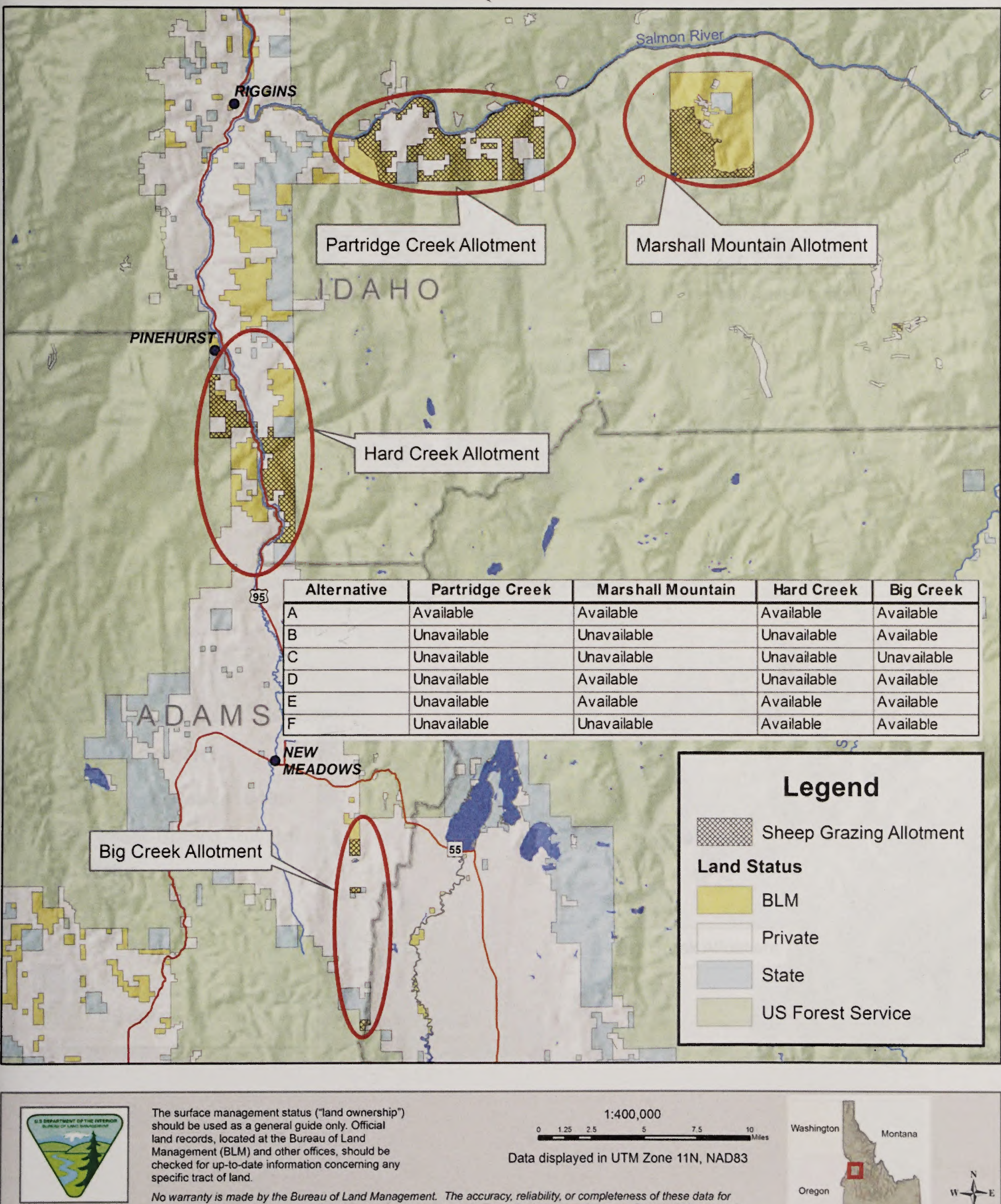

The surface management status ("land ownership") should be used as a general guide only. Officia
land records, located at the Bureau of Land Management (BLM) and other offices, should be

checked for up-to-date information concerning any specific tract of land.

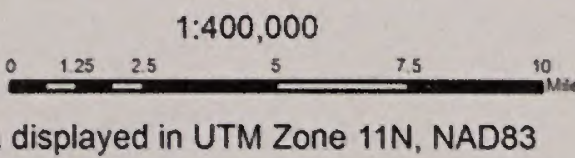

No warranty is made by the Bureau of Land Management. The accuracy, reliability, or complefeness of these data for individual use or aggregate use with other data is not guaranteed. The following cannot be made Section 508 compliant. Map Created: 10/27/2011 For help with its data or information, please contact the BLM Idaho State Office Webmaster at 208-373-4000.

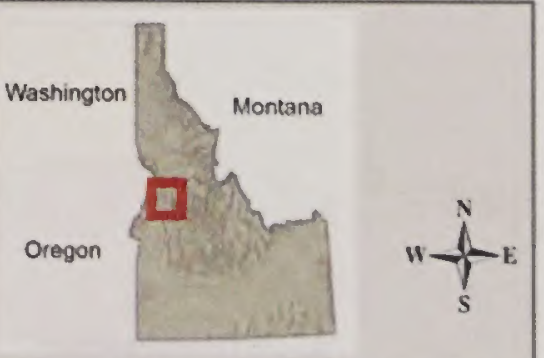




\section{banogu}

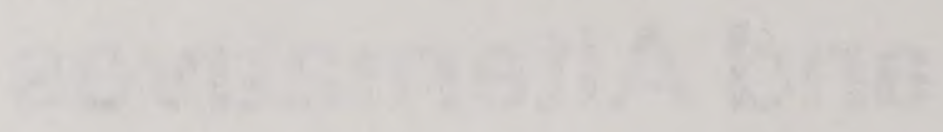

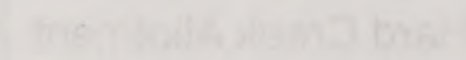




\section{Bighorn Sheep Summer Source Habitat}
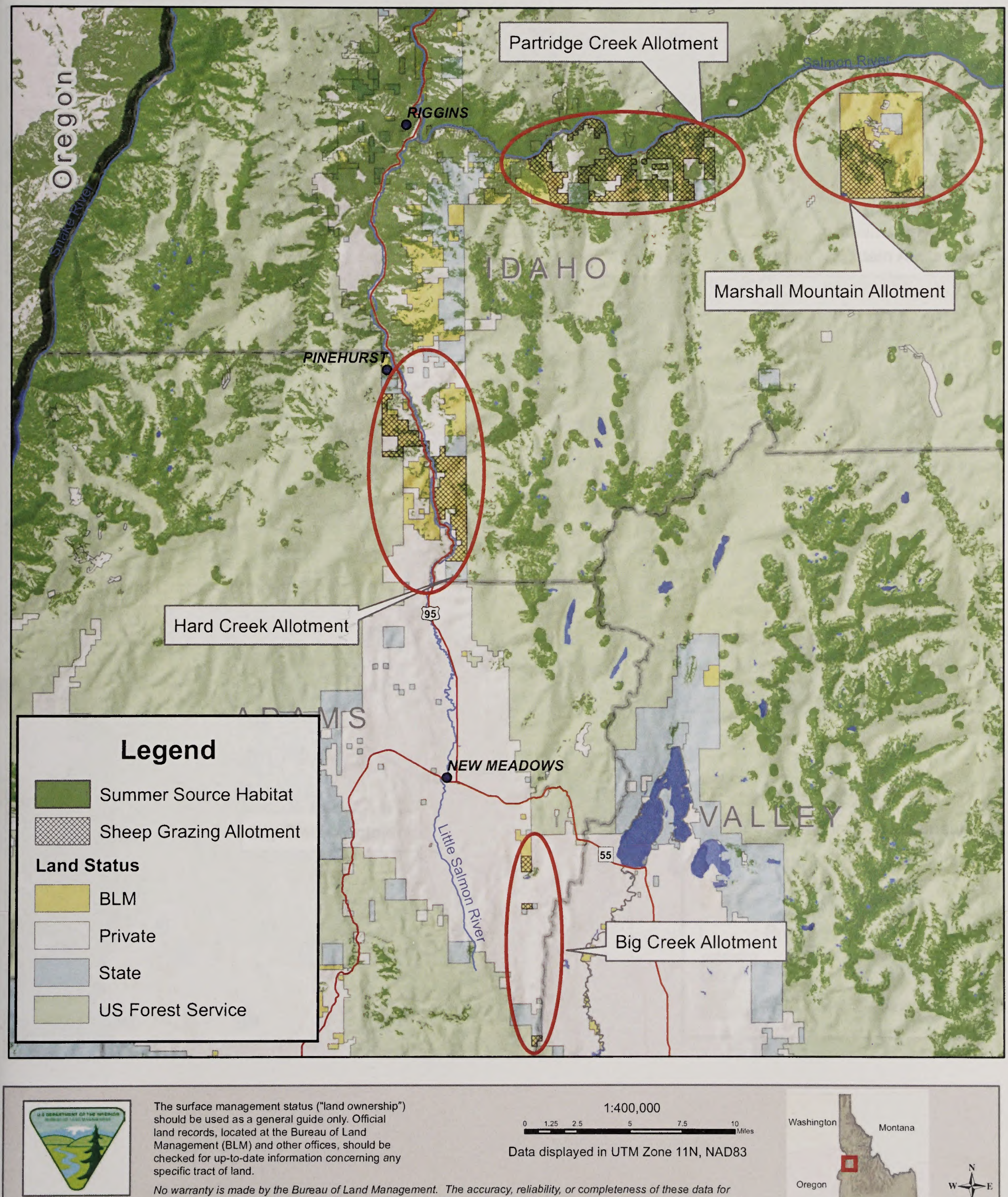

The surface management status ("land ownership") should be used as a general guide only. Official
land records, located at the Bureau of Land Management (BLM) and other offices, should be

checked for up-to-date information concerning any

specific tract of land.

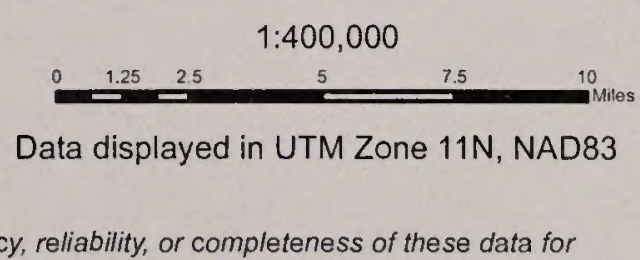

No warranty is made by the Bureau of Land Management. The accuracy, reliabily, or completeness of these data for

For help with its data or information, please contact the BLM Idaho State Office Webmaster at 208-373-4000.

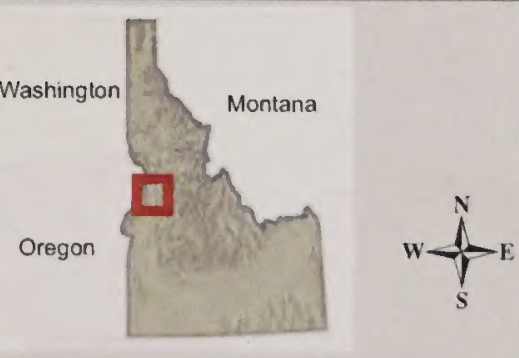





\section{Bighorn Sheep Winter Source Habitat}
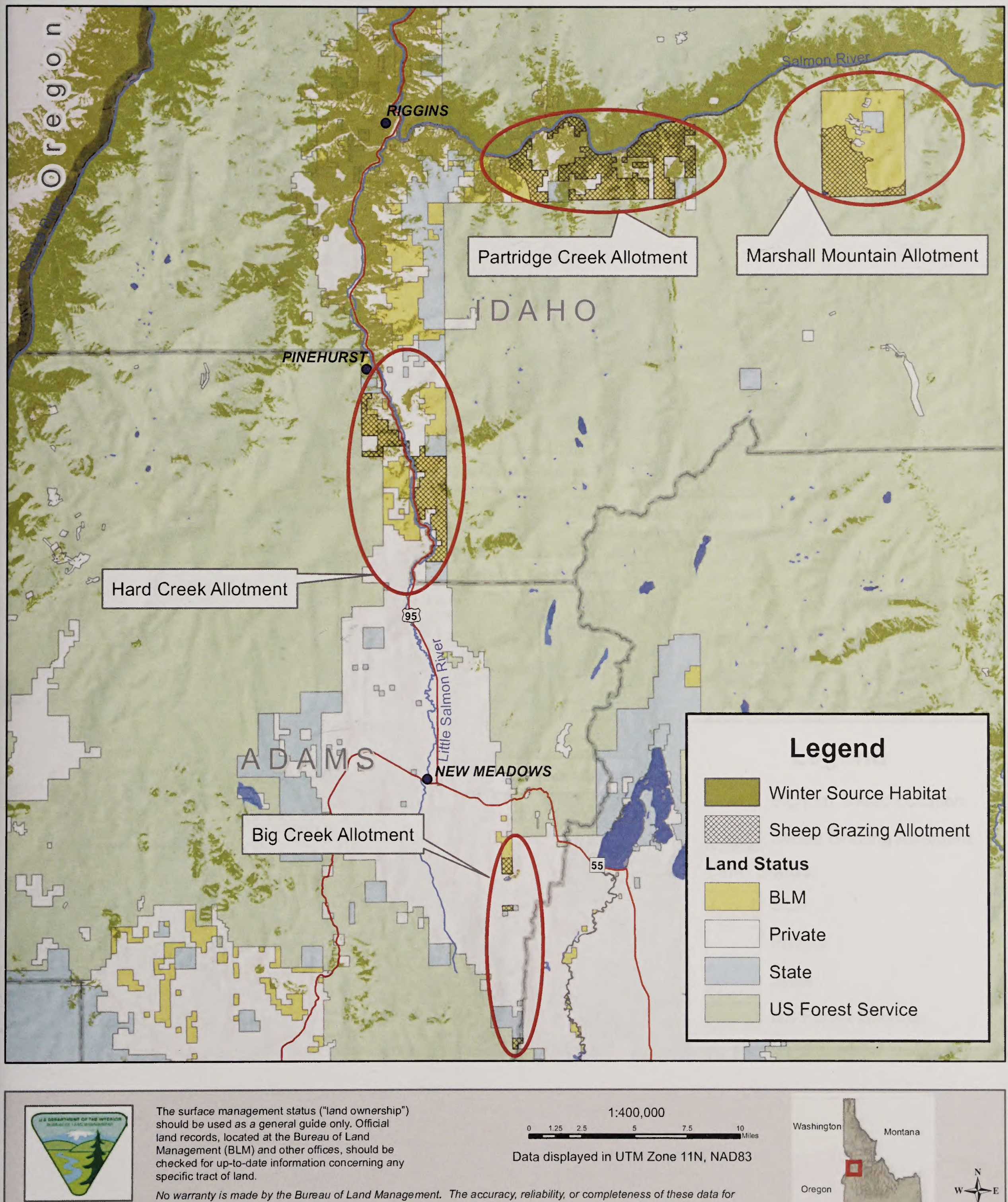

The surface management status ("land ownership") should be used as a general guide only. Official land records, located at the Bureau of Land

Management (BLM) and other offices, should be

checked for up-to-date information concerning any

specific tract of land.

No warranty is made by the Bureau of Land Management. The accuracy, reliability, or completeness of these data for

individual use or aggregate use with other data is not guaranteed. The following cannot be made Section 508 compliant

Map Created: 10/27/2011 For help with its data or information, please contact the BLM Idaho State Office Webmaster at 208-373-4000

$1: 400,000$
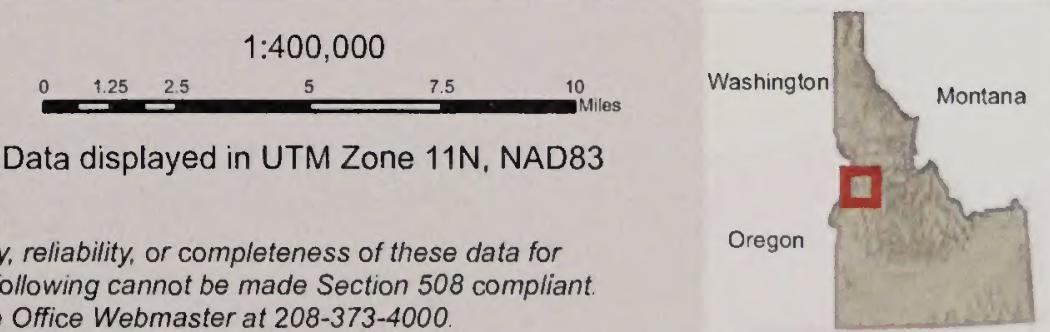


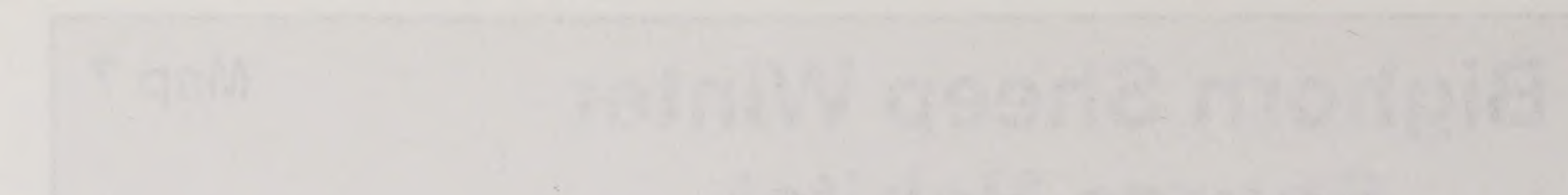




\section{Bighorn Sheep Telemetry and Observation Locations within Analysis Area}
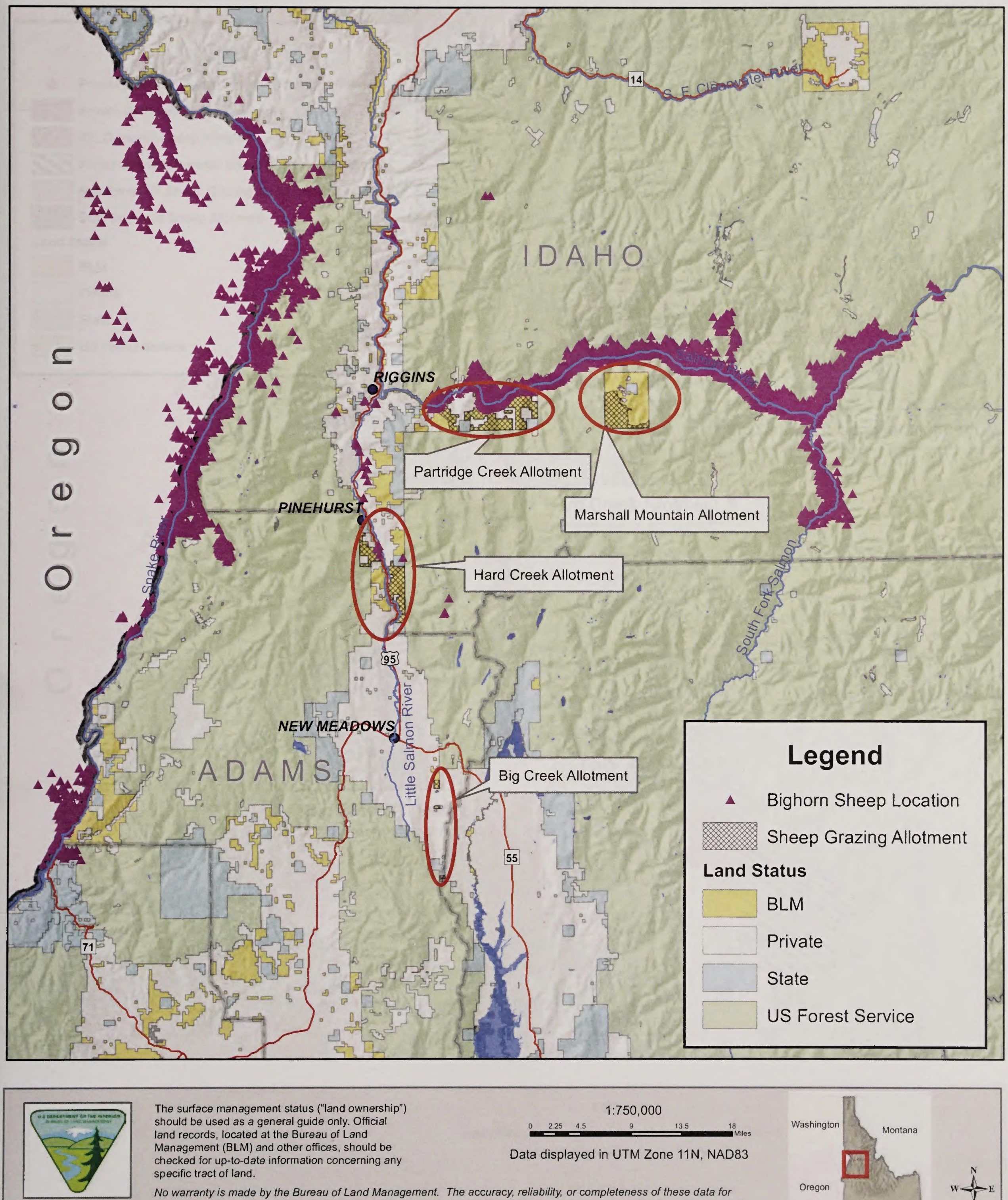

The surface management status ("land ownership") should be used as a general guide only. Official land records, located at the Bureau of Land

Management (BLM) and other offices, should be

checked for up-to-date information concerning any

specific tract of land.

No warranty is made by the Bureau of Land Management. The accuracy, reliability, or completeness of these data for

individual use or aggregate use with other data is not guaranteed. The following cannot be made Section 508 compliant.

Map Created: 10/27/2011 For help with its data or information, please contact the BLM Idaho State Office Webmaster at 208-373-4000.

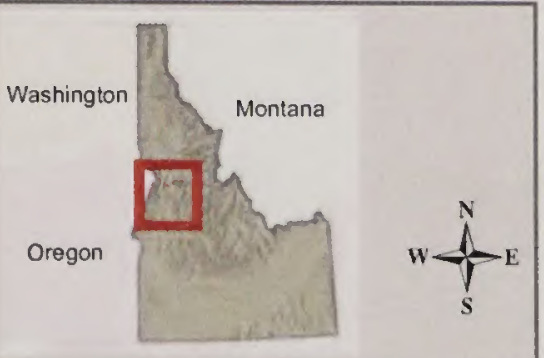




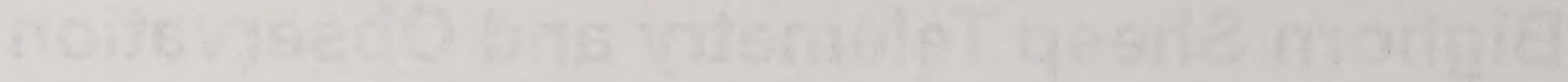

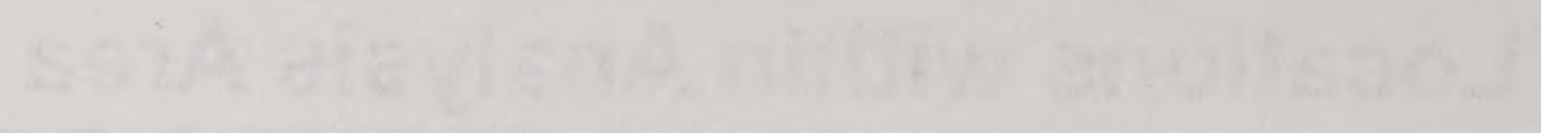




\section{BLM, Forest Service, and State Domestic Sheep Allotments and Private Sheep and Goat Grazing Areas}

\section{Legend}

A Private Domestic Sheep or Goat Grazing ( $<100$ Acres) Private Domestic Sheep Grazing ( $>100$ Acres)

Q/1] IDL Domestic Sheep Allotment

Forest Service Domestic Sheep Allotment (Available)

$\square$ Nez Perce NF Sheep Grazing Allotment (Unavailable)

18. BLM Domestic Sheep Allotment

Land Status

$\square$ BLM
$\square$ Private
$\square$ State
$\square$ US Forest Service
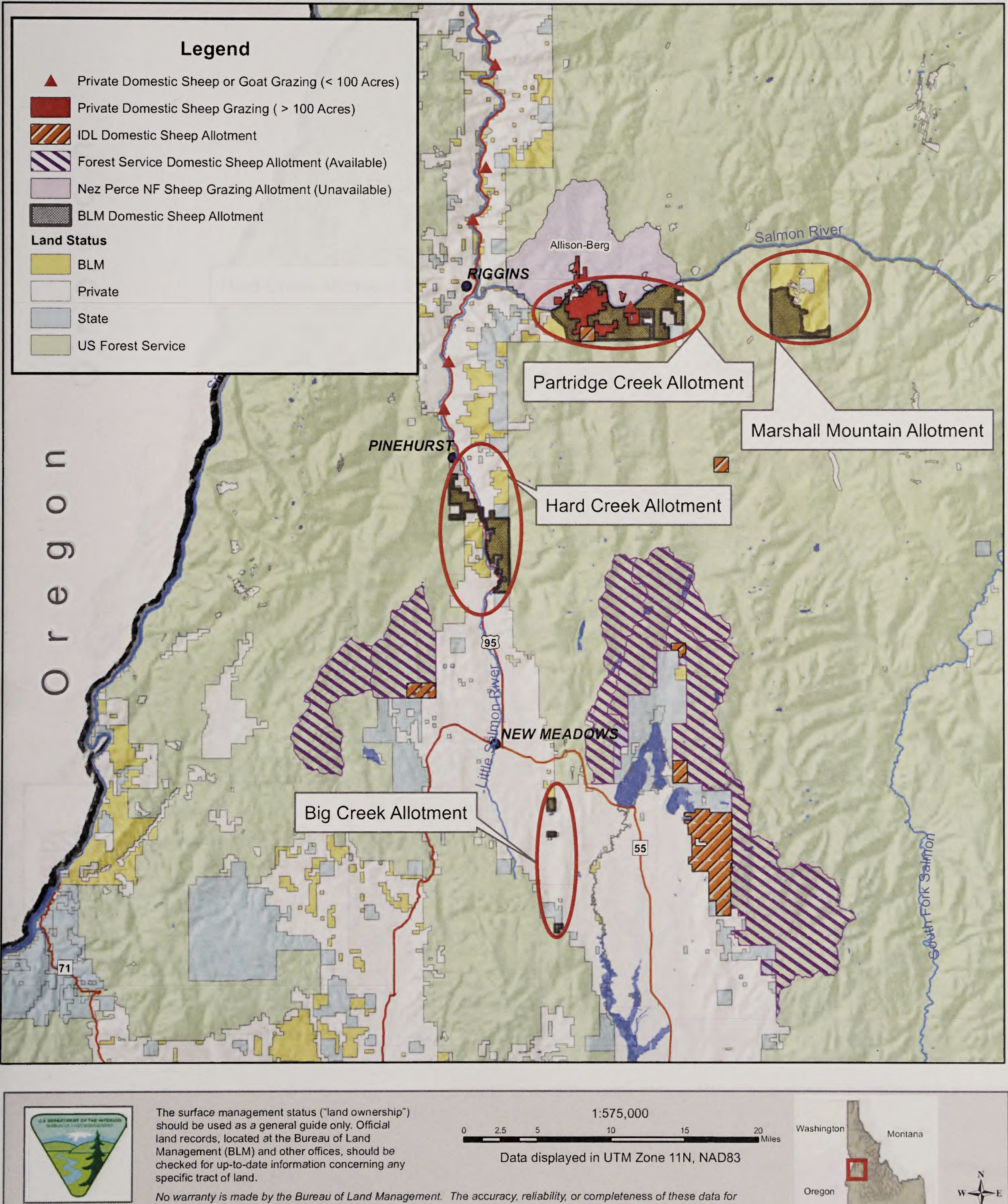

The surface management status ("land ownership") should be used as a general guide only. Officia Management (BLM) and other offices, should be checked for up-to-date information concerning any specific tract of land.

No warranty is made by the Bureau of Land Management. The accuracy, reliability, or completeness of these data for individual use or aggregate use with other data is not guaranteed. The following cannot be made Section 508 compliant. Map Created: 10/27/2011 For help with its data or information, please contact the BLM Idaho State Office Webmaster at 208-373-4000. 



\section{Payette National Forest Plan Amendment}
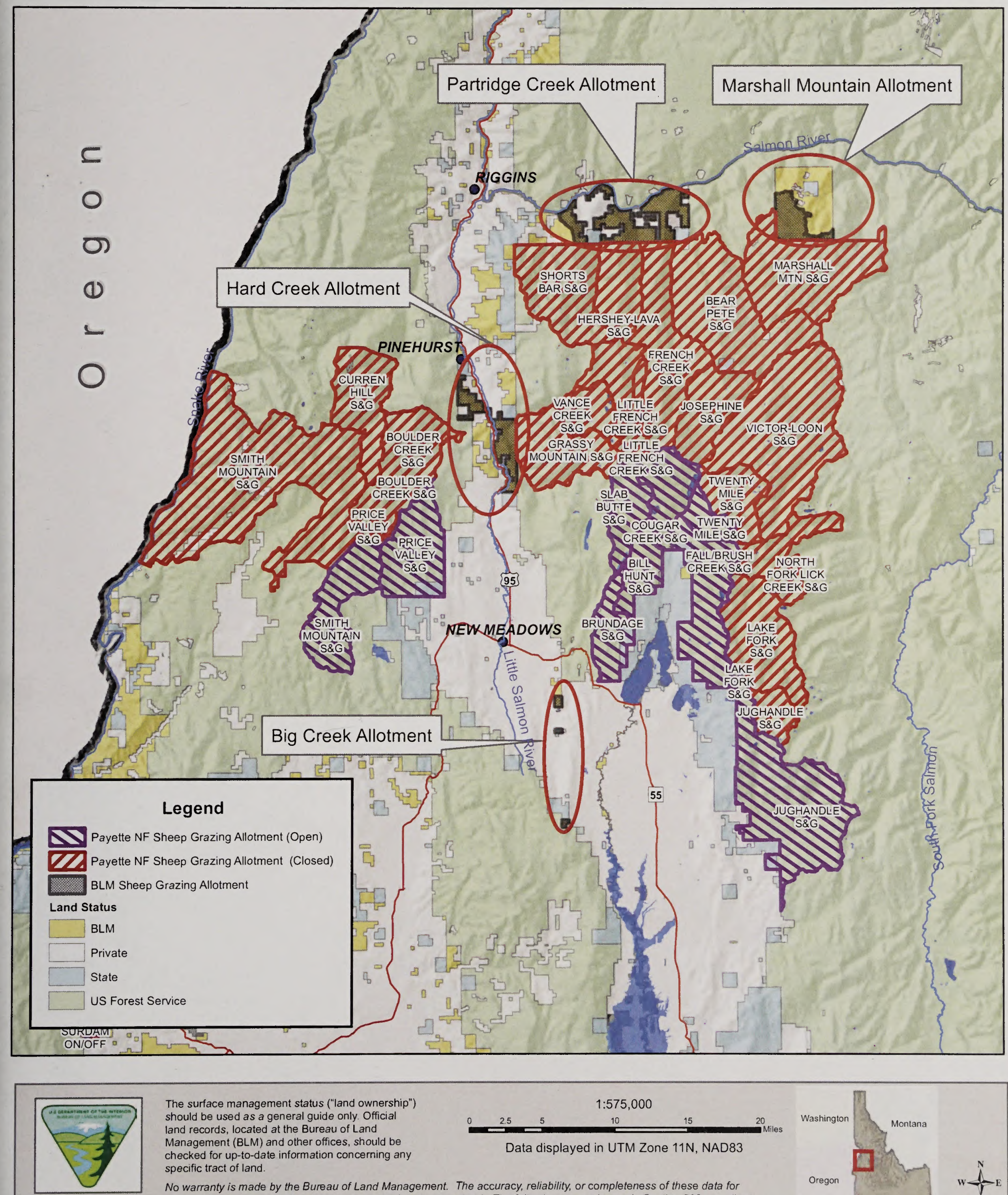

The surface management status ("land ownership") should be used as a general guide only. Official land records, located at the Bureau of Land Management (BLM) and other offices, should be checked for up-to-date information concerning any specific tract of land.

No warranty is made by the Bureau of Land Management. The accuracy, reliability, or completeness of these data for individual use or aggregate use with other data is not guaranteed. The following cannot be made Section 508 compliant

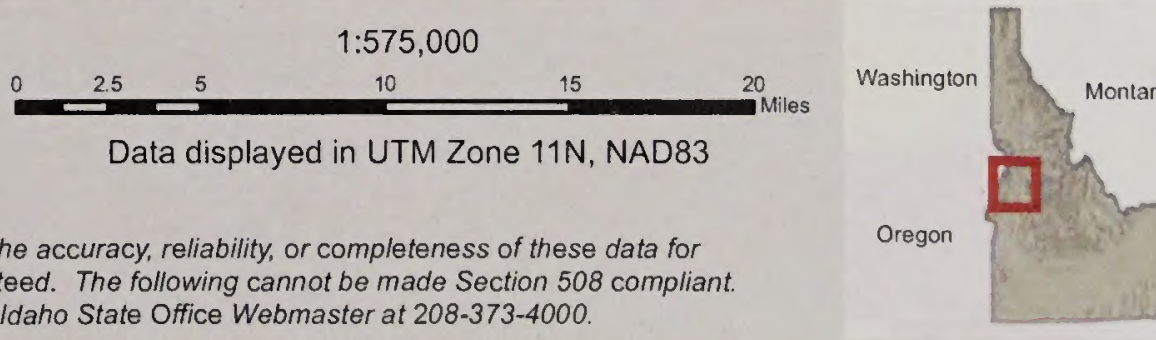




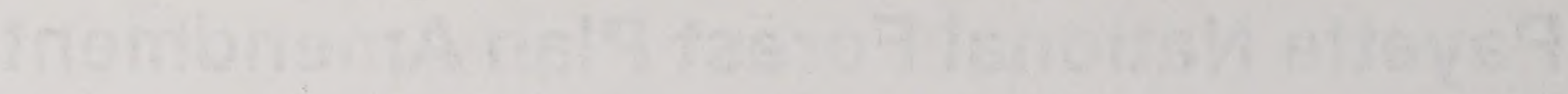


BLM Library

Denver Federal Center

B!dg. 50, OC-521

P.O. Box 25047

Denver, CO 80225 
